AD

\title{
Acute Toxicity of Smoke Screen Materials to Aquatic Organisms, White Phosphorus-Felt, Red Phosphorus-Butyl Rubber and SGF No. 2 Fog OII \\ Final Report
}

\author{
T. M. Poston \\ B. L. Thomas \\ K. M. McFadden \\ B. W. Killand \\ R. M. Bean \\ L. A. Prohammer \\ M. L. Clark \\ D. R. Kalkwarf
}

\section{April 1986}

Supported by

U.S. Army Medical Research and Development Command

Fort Detrick, Frederick, MD 21701

Project Order No. 84PP4800

Pacific Northwest Laboratory

Richland, Washington 99352

Operated for the U.S. Department of Energy

by Battelle Memorial Institute

Project Officer: William H. van der Schalie

Health EHects Research Division

U.S. Army Medical Bioengineering Research and Development Laboratory

Fort Detrick, Frederick, MD 21701

Approved for public release;

distribution unlimited

The findings in this report are not to be construed as an official Department of the Army position unless so designated by other authorized documents 


\title{
DISCLAIMER
}

This report was prepared as an account of work sponsored by an agency of the United States Government. Neither the United States Government nor any agency thereof, nor any of their employees, makes any warranty, express or implied, or assumes any legal liability or responsibility for the accuracy, completeness, or usefulness of any information, apparatus, product, or process disclosed, or represents that its use would not infringe privately owned rights. Reference herein to any specific commercial product, process, or service by trade name, trademark, manufacturer, or otherwise, does not necessarily constitute or imply its endorsement, recommendation, or favoring by the United States Government or any agency thereof. The views and opinions of authors expressed herein do not necessarily state or reflect those of the United States Government or any agency thereof.

\section{NOTICE}

\section{Disclaimer}

The findings in this report are not to be construed as an official Department of the Army position unless so designated by other authorized documents.

\section{Disposition}

Destroy this report when it is no longer needed. Do not return it to the originator.

\author{
PACIFIC NORTHWEST LABORATORY \\ operated by \\ BATTELLE \\ for the \\ UNITED STATES DEPARTMENT OF ENERGY \\ under Contract DE-AC06-76RLO 1830
}

\begin{tabular}{|c|c|}
\hline \multicolumn{2}{|c|}{ Printed in the United States of America } \\
\hline \multicolumn{2}{|c|}{ Available from } \\
\hline \multirow{2}{*}{\multicolumn{2}{|c|}{$\begin{array}{l}\text { National Technical Information Service } \\
\text { United States Department of Commerce }\end{array}$}} \\
\hline & \\
\hline \multicolumn{2}{|c|}{5285 Port Royal Road } \\
\hline \multicolumn{2}{|c|}{ Springfield, Virginia 22161} \\
\hline \multirow{2}{*}{\multicolumn{2}{|c|}{$\begin{array}{l}\text { NTIS Price Codes } \\
\text { Microfiche } A 01\end{array}$}} \\
\hline & \\
\hline \multicolumn{2}{|c|}{ Printed Copy } \\
\hline Pages & $\begin{array}{l}\text { Price } \\
\text { Codes }\end{array}$ \\
\hline $001-025$ & $\mathrm{~A} 02$ \\
\hline 026-050 & $\mathrm{A} 03$ \\
\hline 051-075 & A04 \\
\hline 076-100 & A05 \\
\hline $101-125$ & A06 \\
\hline $126-150$ & $A 07$ \\
\hline $151-175$ & A0B \\
\hline $176-200$ & A09 \\
\hline $201-225$ & A010 \\
\hline $226-250$ & A011 \\
\hline $251-275$ & A012 \\
\hline $276-300$ & A013 \\
\hline
\end{tabular}


AD

PNL -5584

ACUTE TOXICITY OF SMOKE SCREEN MATERIALS TO

AQUATIC ORGANISHS, WHITE PHOSPHORUS-FELT,

RED PHOSPHORUS-BUTYL RUBBER AND SGF NO. 2 FOG OIL

FINAL REPORT

T. M. Poston

K. M. McFadden

R. M. Bean

M. L. C,Tark

B. L. Thomas

B. W. Killand

L. A. Prohammer

D. R. Kalkwarf

APRIL 1986

Supported by

U.S. ARMY MEDICAL RESEARCH AND DEVELOPPIENT COMMAND

Fort Detrick, Frederick, MD 21701

Project Order No. 84PP4800

Pacific Northwest Laboratory

Richland, Wastington 99352

Project Officer: William H. van der Schalie Health Effects Research Division

U.S. ARMY MEDTCAL BIOENGINEERING RESEARCH AND DEVELOPMENT LABORATORY

Fort Detrick, Frederick, MD 21701

Approved for public release;

distribution unlimited

The findings in this report are not to be construed as

an official Department of the Army position unless so designated by other authorized documents 


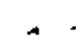

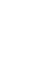

$\checkmark$

เ

$\checkmark$ 
Unclassified

SECURITY CLASSIFICATION OF THIS PAGE (When Dato Entered)

\begin{tabular}{|c|c|}
\hline REPORT DOCUNENTATION PAGE & $\begin{array}{l}\text { READ INSTRUCTIONS } \\
\text { BEFORE COMPLETING FORM }\end{array}$ \\
\hline 2. GOVT ACCESSION NO. & 3. RECIPIENT'S CATALOG NUMBER \\
\hline 4. TITLE (and Subttlle) & 5. TYPE OF REPORT \& PERIOD COVERED \\
\hline \multirow{2}{*}{$\begin{array}{l}\text { Acute Toxicity of Smoke Screen Materials to } \\
\text { Aquatic Organisms, White Phosphorus-Felt, Red } \\
\text { Phorphorus-Buty] Rubber and SGF No. } 2 \text { Fog Oil }\end{array}$} & $\begin{array}{l}\text { Technical Report } \\
1983 \text { to } 1985\end{array}$ \\
\hline & $\begin{array}{l}\text { 6. PERFORMING ORG. REPORT NUMBER } \\
\text { PNL }-5584\end{array}$ \\
\hline $\begin{array}{l}\text { 7. AUThor(s) } \\
\text { T. M. Poston, K. M. McFadden, R. M. Bean, } \\
\text { M. L. Clark, B. L. Thomas, B. W. Killand, } \\
\text { L. A. Prohammer and D. R. Kalkwarf }\end{array}$ & 8. CONTRACT OR GRANT NUMBER( $(\Delta)$ \\
\hline $\begin{array}{l}\text { 9. PERFORMING ORGANizATION NAME AND ADDRESS } \\
\text { Pacific Northwest Laboratory } \\
\text { Richland, WA } 99352\end{array}$ & $\begin{array}{l}\text { 10. PROGRAMELEMENT PROJECT, TASK } \\
\text { AREA \& WORK UNIT NUMEERS }\end{array}$ \\
\hline \multirow{2}{*}{$\begin{array}{l}\text { 11. CONTACLLING OFFICE NAME ANO ADDRESS } \\
\text { U.S. Army Medical Bioengineering Research and } \\
\text { Development Laboratory } \\
\text { Fort Detrich, Frederich, MD } 21701\end{array}$} & $\begin{array}{l}\text { 12. REPORT DATE } \\
\text { September } 30,1985\end{array}$ \\
\hline & 13. NUMEER OF PAGES \\
\hline \multirow[t]{2}{*}{ 14. MONITCRING AGENCY NAME a ADDRESS(it different from Controlsing oflice) } & 15. SECURITY CLASS, (of this roport) \\
\hline & $\begin{array}{l}\text { 15. DECLASSIFICATION/DOWNGRADING } \\
\text { SCHEOULE }\end{array}$ \\
\hline
\end{tabular}

Approved for public release, distribution unlimited

17. DISTRIGUTION STATEMENT fof the obotract ontored in Block 2o. If diffarent froen Roport)

18. SUPPLEMENTAAY NOTES

19. KEY WOROS (Continue on eaveres sida if necessary and identlfy by block number)

Aquatic Toxicity

Red Phorphorus-Butyl Rubber

Environmental Fate

White Phosphorus Felt

Obscurants

SGF No. 2 Fog 011

Smoke Screen Materials

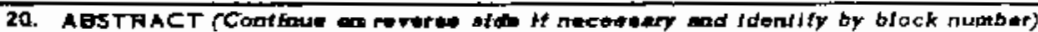

The acute toxicity of three obscurants was determined for nine freshwater organisms. The materials tested were white phosphorus-felt smoke, red phosphorus-butyl rubber ( $R P-B R$ ) smoke, and smoke generator fuel (SGF) No. 2 fog oil (buik and vaporized).

The chemistry of WP-F and RP-BR smoke in water and the resulting effects on aquatic organisms are similar. Combustion of these two obscurants and their 
deposition in water leads to the formation of many complex oxy-phosphoric acids. Rates of hydrolysis of these complex products to ortho-phosphate were inconsistent and unpredictable over time. These products acidify water and produce toxic effects after exhausting the buffering capacity of the water. The 96-hr median lethal concentration (LC50) values for fish ranged from 3.9 to $5.1 \mathrm{pH}$ units. The values for invertebrates ranged from 3.4 to 5.5. Algal growth was inhibited at $\mathrm{pH}$ levels less than 6.0.

Acute $96 \mathrm{hr}$ tests using Daphnia magna with neutralized and non-neutralized exposure solutions indicated that the presence of unidentified toxic component(s) acted independently of $\mathrm{pH}$. Non-pH related toxicity was observed in solutions containing an excess of $50 \mathrm{mg} / L$ total $P$.

At $\mathrm{pH}$ levels of 6.0 to 7.0 , phosphorus combustion products precipitated out of solution leading to a bimoda? toxic response in extended 96-hr tests with Daphnia magna. These effects appeared to be caused by accumulation of the precipitated material in the gastrointestinal tract of exposed organisms. The effect was not observed in exposure solutions that had aged for 26 to 28 days. The bimodal response may be unique to small filter-feeding organisms.

Additions of phosphorus into aquatic systems can lead to stimulation of algal growth as long as the resulting $\mathrm{pH}$ is not toxic. Stimulation of algal growth to nuisance levels is a potentially serious adverse effect resulting from the deposition of phosphorus smoke into aquatic systems.

Most components of fog $0 i 1$ had low solubility in water. Saturation was apparent at approximately 0.1 to $0.3 \mathrm{mg} / \mathrm{L}$ total oil. The composition of the organic constituents of oil-water mixes was different than what would have been predicted from the composition of the bulk fog oil. These differences reflect the different solubility of the lower molecular weight constituents relative to the total composition of the oil. Vaporization had no demonstrable effect on the chemistry or toxicity of the fog oil.

Neither the bulk fog oil nor the vaporized fog oil was acutely toxic to freshwater animals at concentrations less than $10 \mathrm{mg} / \mathrm{L}$ total oil. In oil-water mixes in excess of $1.0 \mathrm{mg} / \mathrm{L}$ total oil, fog oil quickly separated and floated to the surface. The primary hazard associated with vaporized and bulk fog oil was the physical effect of oil fouling the organisms. Impairment of swimming in first instar $\underline{D}$. magna was observed at nominal concentrations of 0.03 to $0.10 \mathrm{mg} / \mathrm{L}$ totă $0 \mathrm{il}$.

Concentrations of bulk fog 017 in excess of $2.4 \mathrm{mg} / \mathrm{L}$ total oil significantly inhibited algal growth in two of the three batches tested. Vaporized fog oil at concentrations as high as $2.38 \mathrm{mg} / \mathrm{L}$ total oil had no apparent effect on algal growth. Because the concentrations at which these effects were observed exceeded the solubility of fog oil in water, it is not possible to attribute the inhibition to chemical toxicity or to a physical effect of the oil.

Photolysis increased the concentration of water-soluble components of the fog oil. Photolytic products formed most likely include aromatic ketones and carboxylic acids. Acute toxicity was demonstrated in oil-water mixes ( $10 \mathrm{mg} / \mathrm{L}$ total oil) of photolyzed bulk and vaporized fog oil. No difference in toxicity was observed between photolyzed and non-photolyzed dilutions of OWl at comparable levels of total oil. 


\section{EXECUTIVE SUMMARY}

The acute toxicity of three obscurants was determined for nine freshwater organisms. The materials tested were white phosphorus-felt smoke, red phosphorus-butyl rubber (RP-BR) smoke, and smoke generator fuel (SGF) No.? fog oil (bulk and vaporized).

The chemistry of WP-F and RP-BR smoke in water and the resulting effects on aquatic organisms are similar. Combustion of these two obscurants and their deposition in water leads to the formation of many complex oxy-phosphoric acids. Rates of hydrolysis of these complex products to ortho-phosphate were inconsistent and unpredictable over time. These products acidify water and produce toxic effects after exhausting the buffering capacity of the water. The 96-hr median lethal concentration (LC50) values for fish ranged from 3.9 to $5.1 \mathrm{pH}$ units. The values for invertebrates ranged from 3.4 to 5.5 . Alga growth was inhibited at pH levels less than 6.0.

Acute $96 \mathrm{hr}$ tests using Daphnia magna with neutralized and nonneutralized exposure solutions indicated that the presence of unidentified toxic component $(\mathrm{s})$ acted independently of $\mathrm{pH}$. Non-pH related toxicity was observed in solutions containing an excess of $50 \mathrm{mg} / \mathrm{L}$ tota? $\mathrm{P}$.

At $\mathrm{pH}$ levels of 6.0 to 7.0 , phosphorus combustion products precipitated out of solution leading to a bimodal toxic response in extended $96-\mathrm{hr}$ tests with Daphnia magna. These effects appeared to be caused by accumulation of the precipitated material in the gastrointestinal tract of expcsed organisms. The effect was not observed in exposure solutions that had aged for 26 to 28 days. The bimodal response may be unique to sma 1 ? filter-feeding organisms.

Additions of phosphorus into aquatic systems can lead to stimulation of algal growth as long as the resulting $\mathrm{pH}$ is not toxic. Stimulation of algal growth to nuisance levels is a potentialiy serious adverse effect resulting from the deposition of phosphorus smoke into aquatic systems.

Most components of fog oil had low solubility in water. Saturation was apparent at approximately 0.1 to $0.3 \mathrm{mg} / \mathrm{L}$ total $0 i$ ? The composition of the organic constituents of oil-water mixes was different than what would have been predicted from the composition of the bulk fog oil. These differences reflect the different solubility of the lower molecular weight constituents relative to the total composition of the oil. Vaporization had no demonstrable effect on the chemistry or toxicity of the fog $0 i 1$.

Neither the bulk fog oil nor the vaporized fog oil was acutely toxic to freshwater animals at concentrations less than $10 \mathrm{mg} / \mathrm{L}$ total oil. In 
oil-water mixes in excess of $1.0 \mathrm{mg} / \mathrm{L}$ tota $10 \mathrm{il}$, fog oil quickly separated and floated to the surface. The primary hazard associated with vaporized and bulk fog oil was the physical effect of oil fouling the organisms. Impairment of swimming in first instar D. magna was observed at nominal concentrations of 0.03 to $0.10 \mathrm{mg} / \mathrm{L}$ total 0 il.

Concentrations of bulk fog oit in excess of $2.4 \mathrm{mg} / \mathrm{L}$ total oil significantly inhibited algal growth in two of the three batches tested. Vaporized fog oil at concentrations as high as $2.38 \mathrm{mg} / \mathrm{L}$ total oil had no apparent effect on algal growth. Because the concentrations at which these effects were observed exceeded the solubility of fog 011 in water, it is not possible to attribute the inhibition to chemical toxicity or to a physical effect of the 01$\}$.

Photolysis increased the concentration of water-soluble components of the fog 011 . Photolytic products formed most likely include aromatic ketones and carboxylic acids. Acute toxicity was demonstrated in oil-water mixes $(\sim 10 \mathrm{mg} / \mathrm{L}$ total $0 \mathrm{il})$ of photolyzed bulk and vaporized fog oil. No difference in toxicity was observed between photolyzed and non-photolyzed dirutions of OWM at comparable levels of total oil.

The three obscurants tested have the potential for adverse environmental effects. On a relative scale, however, none of the materials can be considered highly toxic until very large quantities (e.g., $>10 \mathrm{mg} / \mathrm{L}$ ) enter freshwater systems. A more extensive assessment requires evaluation of the amount of material released to the environment, the site-specific characteristics of the receiving waters, and the biota inhabiting the site. 
EXECUTIVE SUMMARY $\ldots \ldots \ldots \ldots \ldots \ldots \ldots \ldots \ldots \ldots \ldots \ldots \ldots \ldots \ldots \ldots \ldots \ldots \ldots \ldots$

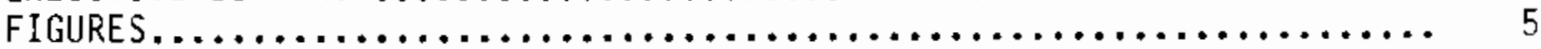

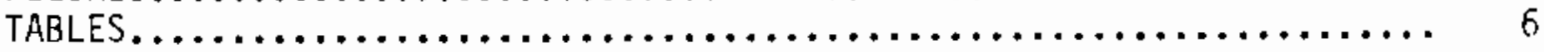

1.0 INTRODUCTION................................. 14

2.0 METHODS................................... 15

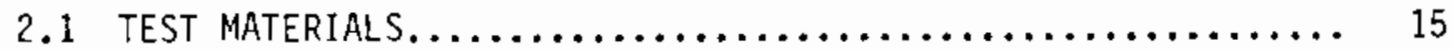

2.2 AEROSOL GENERATION................................ 16

2.2.1 Red Phosphorus-Buty1 Rubber and White Phosphorus

Felt.................................. 16

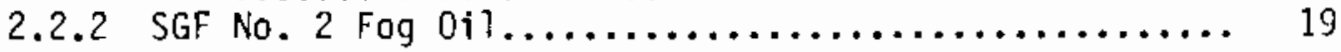

2.3 ANALYSIS OF PHOSPHORUS COMBUSTION PRODUCTS ............ 23

2.3.1 ICP Analysis of Total Phosphorus.............. 23

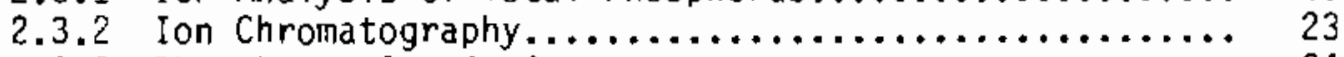

2.3 .3 Phosphorus Speciation........................ 24

2.3 .4 other Analytical Techniques.................. 25

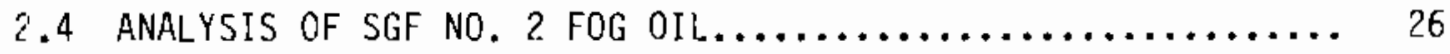

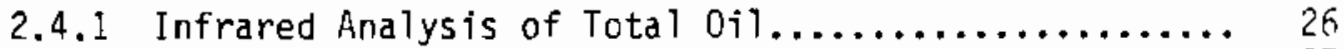

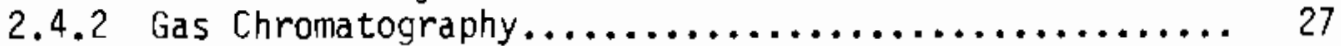

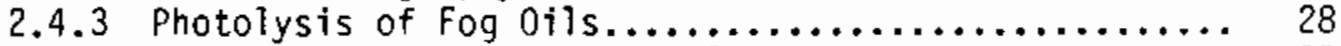

2.4 .4 Analysis of Photolyzed Fog $011 \ldots \ldots \ldots \ldots \ldots \ldots \ldots \ldots . \ldots \ldots$

2.5 CULTURE AND CARE OF TEST ORGANISMS................. 29

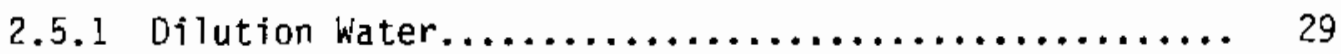

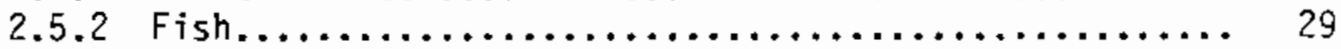

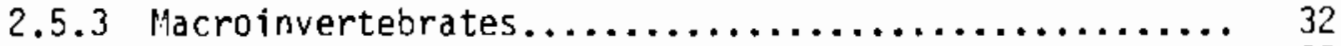

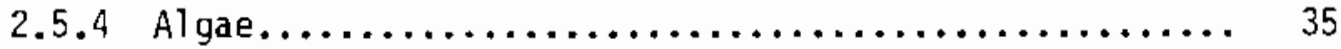

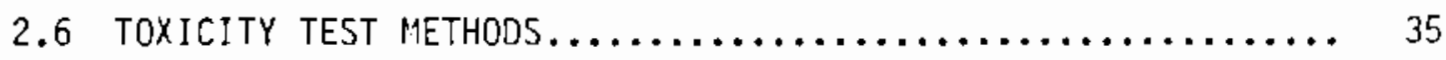

2.6.1 Preparation of Exposure Solutions.............. 35

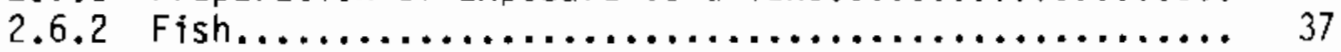

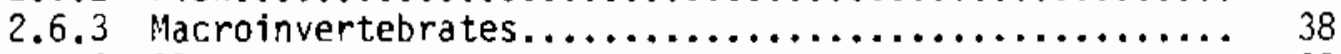

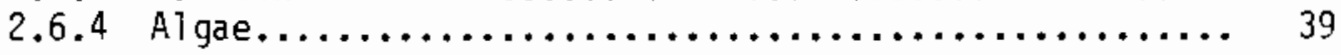

2.7 STATISTICAL METHODS........................ 40 


\section{TABLE OF CONTENTS (Cont.)}

Page

2.7.1 Toxicity Data................................. 41

2.7.2 Algal Toxicity and Growth Stimulation Tests.......... 41

3.0 RESULTS

3.1 AEROSOL GENERATION.................................. 43

3.1.1 Red Phosphorus-Butyl Rubber and white Phosphorus-Fe1t............................ 43

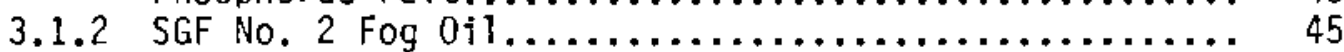

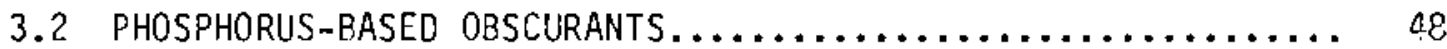

3.2.1 Chemistry,................................... 48

3.2 .2 Toxicity...................................... 59

3.3 SGF NO. 2 FOG $0 I L \ldots \ldots \ldots \ldots \ldots \ldots \ldots \ldots \ldots \ldots \ldots \ldots \ldots \ldots \ldots \ldots \ldots \ldots, 78$

3.3.1 Fog 011 Characterization (Phase I) ............... 78

3.3.2 Characterization of Photolyzed Fog 0 ils............... 86

3.3.3 Evatuation of 0ther Methods for Monitoring OWMs...... 94

3.3 .4 Toxicity of SGF No. 2 Fog $0 i 1 \ldots \ldots \ldots \ldots \ldots \ldots \ldots . . .65$

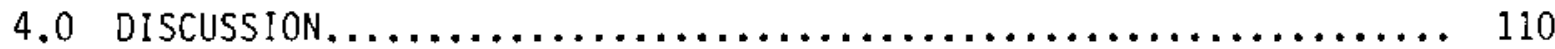

4.1 PHOSPHORUS-BASED OBSCURANTS......................... 110

4.1 .1 Aerosol Generation............................. 110

4.1 .2 Aqueous Chemistry............................. 111

4.1.3 Aquatic Toxicity................................ 112

4.2 SGF NO. 2 FOG OIL.............................. 116

4.2.1 Fog 0 il Vapor Generation......................... 116

4.2 .2 Fog 011 Chemistry............................... 117

4.2 .3 Aquatic Toxicity.............................. 118

4.3 FIELD EXTRAPOLATIONS $\ldots \ldots \ldots \ldots \ldots \ldots \ldots \ldots \ldots \ldots \ldots \ldots \ldots, 121$

4.3.1 Phosphorus-Based 0bscurants $\ldots \ldots \ldots \ldots \ldots \ldots \ldots \ldots \ldots, 121$

4.3 .2 Fog $011 \ldots \ldots \ldots \ldots \ldots \ldots \ldots \ldots \ldots \ldots \ldots \ldots \ldots \ldots \ldots \ldots \ldots \ldots, 123$

5.0 CONCLUSION AND RESEARCH RECOMMENDATIONS $\ldots \ldots \ldots \ldots \ldots \ldots \ldots \ldots, 125$

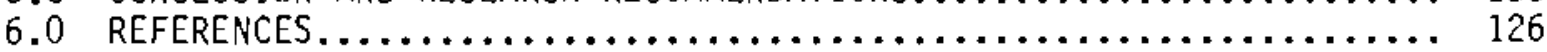


TABLE OF CONTENTS (Cont.)

Page

APPENDIX A. CHARACTERISTICS OF DILUTION WATER USED FCR TESTING...... 130

APPENDIX B. ALGAL MEDIA.................................. 139

APPENDIX C. TOXICITY TEST DATA: PHOSPHORUS BASED OBSCURANTS ....... 142

APPENDIX D. PHASE II GLP REQUIREMENTS ....................... 159

\section{LIST OF FIGURES}

Page

1. Fhosphorus Smoke Generation System.................... 17

2. Filter Sampling Device for Phosphorus Smoke Generation System.... 18

3. Fog $0 i 1$ Vapor Generating and Collection System,............. 20

4. Fog $0 i 1$ Vapor Generator........................... 21

5. Fog $0 i 1$ Vapor Collection System with MYSTAIRE Scrubber........ 22

6. Change in Dilution Water Following Settling of RP-BR Smoke (Burn RP-1) .................................... 49

7. Effect of RP-BR Smoke Bubbled Through Well Water (117 mg/L Alkalinity)..................................... 49

8. Cias Chromatogram of a Fog $0 i 1$ Aromatic Hydrocarbon Fraction...... 80

9. JR Scans of Selected 0WM Extractions and Standard Solutions of known Amounts of Fog $0 i t$ in Carbon Tetrachloride........... 82

10. Chromatogram of the Aromatic Hydrocarbons from an Unfiltered

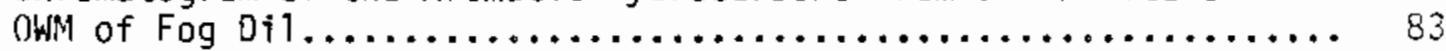

11. Infrared Scans of Thin Films of Batch 3 Bulk Fog $0 i 1 \ldots . . . \ldots .68$

12. Infrared Scans of Thin Films of Vaporized Fog $0 i 1 \ldots \ldots \ldots \ldots . \ldots 8$

13. Infrared Scans of Thin Films of Fog Dil................. 89

14. Infrared Scan of Thin Film of Untreated Fog $0 i 1$ plus $10 \%$

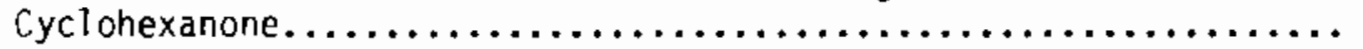




\section{LIST OF FIGURES (Cont.)}

Page

15. Infrared Scan of Thin Filn of Batch 3 Fog $0 i 1$ Photolyzed for

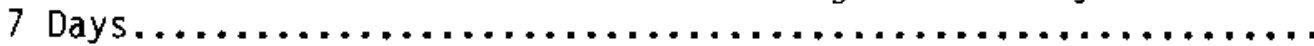

16. Capillary Gas Chromatograms of Isooctane Extract of Water

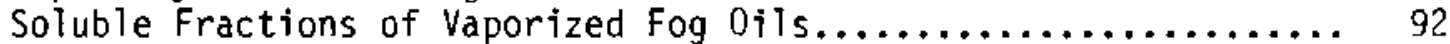

17. Capillary Gas Chromatogram of Isooctane Extract of Water Soluble Fraction of 24-hr Photolyzed/Vaporized Fog 0il.............. 92

18. Total Ionization Chromatogram of Hexane-Extractable Components from Water Soluble Fraction of Vaporized, 7-Day Photolyzed Fog 0 il . . .

1. Project Identification of Three Batches of SGF No. 2 Fog $0 i 1 \ldots . . .15$

2. Conditions Used in Separation of Linear and Cyclic Condensed Phosphates....................................... 25

3. Marking and Dawson (1973) Reconstjtuted Freshwater........... 30

4. Basic Water Chemistry of Columbia River Water and Well Water..... 30

5. Measured Concentrations (mg/L) of Components in Dilution Water Used in Toxicity Tests......................... 31

6. General Information of Fish Used During Phase II Toxicity

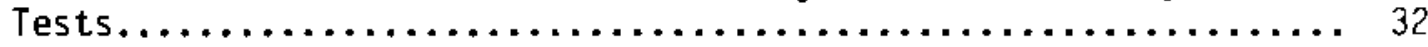

7. General Information on Macroinvertebrates Used During Phase II Toxicity Tests..................................

8. Summary of RP-BR Smoke Generation and the Relationship Between Smoke Concentration and Phosphorus Content in Stock Solutions.... 44

9. Sumary of WP-F Smoke Generations and the Relationship Between Smoke Concentration and Phosphorus Content in Stock Solutions.... 46

10. Summary of Fog $0 i\}$ Vapor Generations................. 47 


\section{LIST OF TABLES (Cont.)}

Page

11. Change in Soluble Elements in Well Water Solutions, According to Age and Concentration, from a RP-BR Combustion (Burn RP-4).... 50

12. Shange in Soluble Elements in Well Water Solutions, According to Age and Concentration, from a W/P-F Combustion (Burn WP-5).... 51

13. Significant Losses in Solubility with Time for Diluted (40\%), Unneutralized 331 Well Water Aliquots................... 52

14. Comparison of $P 0-P$ to Total $P$ in RP-BR Smoke Contacted with Well Water, as a Function of Solution Age and Dilution......... 53

15. Comparison of P0 $-P$ to Total $P$ in WP-F Smoke Contacted with Well Water, as a Function of Solution Age and Dilution.......... 54

16. Precipitation from Neutralized Well Water (117 mg/L alkalinity) and Reconstituted Very Hard Water $(230 \mathrm{mg} / \mathrm{L})$ Alkalinity after Contact with WP - F Smoke.............................. 55

17. Distribution of Phosphorus Species in Neutralized and NonNeutralized WP-F Solutions from Smoke Contacts After Aging...... 56

18. Distribution of Phosphorus Species in Hard Water Solutions Using $\mathrm{Na}$ EDTA Eluents............................... 57

19. Phosphorus Distribution With Time in RP-BR Smoke Contacted Waters......................................... 58

20. RP-BR and WP-F Stock Solutions Used with Daphnia magna Toxicity Tests During Phase I............................... 60

21. RP-BR and WP-F Stock Solutions Used During Phase II Tests with Columbia River Water.............................. 61

22. Bimodal Response of $\underline{D}$. magna over $96 \mathrm{hr}$, Burn RP-5......... 62

23. Toxicity (\% mortality, $n=24$ ) of RP-BR Smoke-Dosed water to D. magna as a Function of Age of the Exposure Solutions (Bu $\overline{\mathrm{rn} W P}-5$ ).

24. Toxicity (\% Mortality, $n=24$ ) of RP-BR Smoke to Daphnia magna as a Function of Age of the Exposure Solutions. 


\section{LIST OF TABLES (Cont.)}

Page

25. Comparison of Mortality of Daphnia magna in Neutralization

Tests with Four Types of DiTution waters................... 66

26. Analys is of Varjance (ANOVA) of Mean Cell Count Data from

the Algal Toxicity Test With RP-BR....................... 67

27. F-Values for Comparisons Between All Possible Pairs of Means at

$0,24,48,72$, and 96 Hours for RP-BR Toxicity Test with

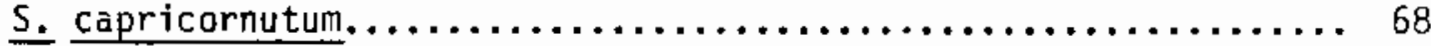

28. Response of $S$. capricornutum to RP-BR Smoke Dosed Water

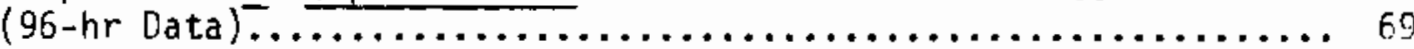

29. Analysis of Variance (ANOVA) of Mean Cell Count Data from the Algal Toxicity Test with WP-F....................... 70

30. Response of $\underline{S}$. capricornutum to WP-F Smoke-Dosed Water

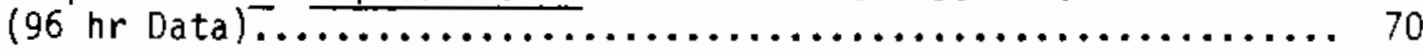

31. Analysis of Variance (ANOVA) of Algal Stimulation Tests with

RP-BR (Based on 96-hr Mean Cell Counts).................. 71

32. F-Values for Comparisons Between All Possible Pairs of Means at

$0,24,48,72$, and 96 Hours for RP-BR Algal Stimulation Tests.... 72

33. Response of $S$. capricornutum in Algal Stimulation Tests with

RP-BR Smoke-Dosed PO Deficient Media...................... 73

34. Analysis of Variance (ANOVA) of Algal Stimulation Tests with

WP-F....................................... 74

35. F-Values for Comparisons Between All Possible Pairs of Means at

$D, 24,48,72$, and 96 Hours for WP-F ATgal Stimulation Tests.... 75

36. Response of Selenastrum capricornutum in Algal Stimulation

Tests with WP-F Smoke-Dosed PO -Deficient Media (96-hr Data..... 76

37. Median Lethal Concentration (LC50) Values of WP-F and RP-Br

Toxicity Tests...................................... 77

38. Infrared Determination of Fog $0 i 1$ Concentration of $0 i 1$-Water

Mixtures (OWM) 


\section{LIST OF TABLES (Cont.)}

$\underline{\text { Page }}$

39. Bulk Fog 0 il O4M! Aromatic Hydrocarbon Concentrations in g/L.... 84

40. Vaporized Fog 011 OWM Aromatic Hydrocarbon Concentrations

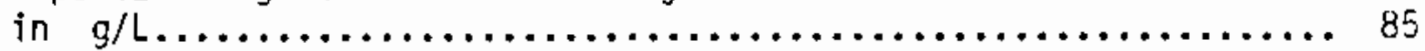

41. Vaporized Fog $0 i 1$ (FO-3) OWM Aromatic Hydrocarbon Fraction

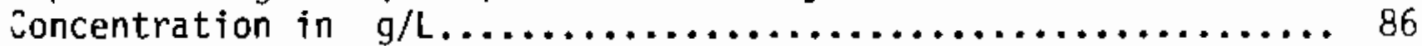

42. Free Radical Concentrations in Photolyzed Fog $011 \mathrm{~s}, \ldots . . . \ldots . . .87$

43. Measured Total Organic Carbon in Filtered and Non-Filtered $0 i 1 /$ water Mixtures and well Water Samples..................... 95

44. Sunmary of Mortalities (\%) and Floaters from Screening Toxicity Tests of Bulk and Vaporized (Fo-1) Batch 1 Fog $0 i 1 \ldots . . . \ldots . . . . .96$

45. Mortality Data of $D$. magna Exposed to OWM of Batch 1 Vaporized

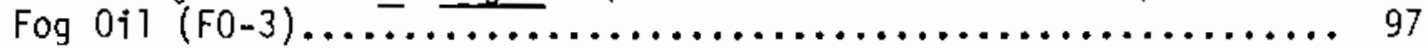

46. Summary of $96-h r$ Batch Screening Toxicity Tests with $\underline{P}$. promelas. 99

47. Summary of 48-hr Batch Screening Toxicity Tests with Hexagenia... 99

48. Comparison of Algal Toxicity of Three Batches of SGF No. 2 Fog 0 il Based on the $96-$ hr Mean Cell Counts...................... 100

49. Analysis of Variance (ANOVA) of Mean Cell Count Data from the Algal Toxicity Test with Batch 1 Fog $0 i 1 \ldots . . . \ldots . . . . . . . . . .100$

50. F-Values for Comparisons Between A1l Possible pairs of Means at $0,24,48,72$, and 96 Mours for Batch 1 Fog $0 i 1 \ldots \ldots \ldots \ldots \ldots . . . . .101$

51. Analysis of Variance (ANOVA) of Meàn Cell Count Data from the Algal Toxicity Test with Batch 2 Fog $0 i 1 \ldots \ldots \ldots \ldots \ldots . . . \ldots . . .102$

52. F-Values for Comparisons Between All Possible Pairs of Means at $0,24,48,72$, and 96 Hours for Batch 2 Fog $011 \ldots \ldots \ldots \ldots . . .102$

53. Analysis of Variance (ANOVA) of Mean Cell Count Data from the Algal Toxicity Test with Batch 3 Fog 0 i\}................. 103

54. Analysis of Variance (ANOVA) of Mean Cell Count Data from the Algal Toxicity Test with Vaporized Batch 3 Fog $0 i 1 . . . . . . . .104$ 


\section{LIST OF TABLES (Cont.)}

Page

55. Responses of Selenastrum capricornutum to Vaporized 8atch 3

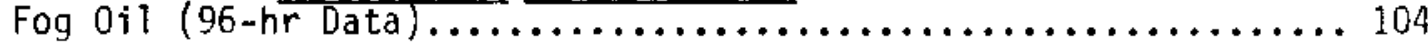

56. Observations (\%) of Daphnia magna Exposed to 0WM of Batch 3

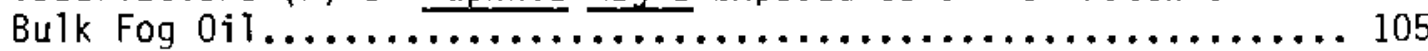

57. Observations (\%) of Daphnia magna Exposed to OWl of Batch 3

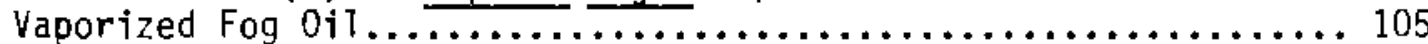

5B. Exposure of Paratanytarsus Dissimilus to OWl of Bulk and

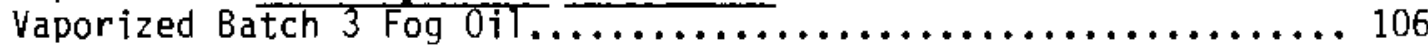

59. Summary of Hyallela azteca Mortality (\%) in Screening Toxicity Test with Photolyzed Batches of Bulk and Vaporized Fog 0il...... 107

60. Toxicity Testing Results of Hyallela azteca and bulk fog $0 i 1$, 7-Day Photolyzed Bulk Fog 0iT, Vaporized Fog 0il, and Photolyzed-Vaporized Fog $0 i 1 \ldots \ldots \ldots \ldots \ldots \ldots \ldots \ldots \ldots . \ldots \ldots$

61. Retesting of $100 \%$ Exposure Solutions of 7-Day Photolyzed Fog 0i1. 109

62. Comparative Toxicity to Daphnids of Integrated Two-Stage Liquifaction (ITSL), Exxon Donor Solvent (EDS), and Several Reference Materials................................. 120

63. Relationship Between Buffering Capacity and Total Phosphorous

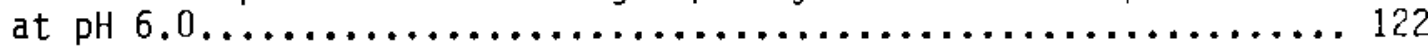

A.1. Mean Cell Counts $( \pm 1.0$ SD) for Selenastrum capricornutum

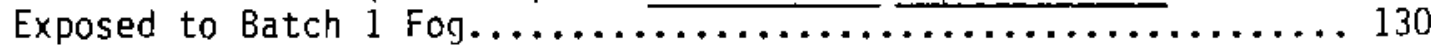

A.2. Mean Cel1 Counts $( \pm 1.0$ SD) for Selenastrum capricornutum Exposed to Batch 2 Fog $0 i 1$

A.3. Mean Cell Counts ( \pm 1.0 SD) for Selenastrum capricornutum

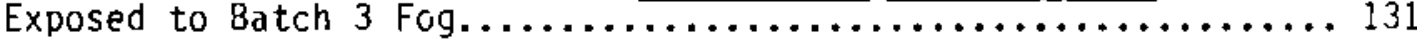

A.4. Mean Cell Counts ( \pm 1.0 SD) for Selenastrum capricornutum

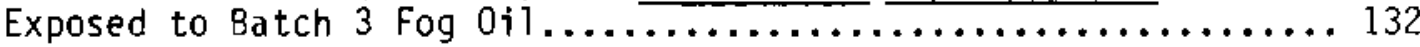

A.5. Mean Cell Counts $( \pm 1.0$ SD) for Selenastrum capricornutum

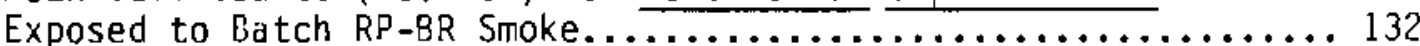

A.6. Mean Cell Counts ( \pm 1.0 SD) for Algal Stimulation Tests with RP-BR. 
A.7. Mean Cell Counts $( \pm 1.0$ SD) for Selenastrum capricornutum Exposed to Batch WP-F Smoke............................. 134

A.8. Mean Cell Counts ( \pm 1.0 SD) in Algal Stimulation Tests with WP-F.. 135

A.9. Response of Selenastrum capricornutum to RP-BR Smoke-Dosed

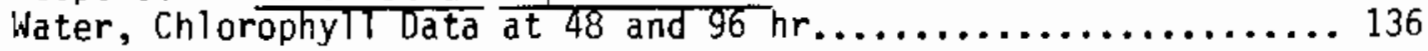

A.10. Response of Selenastrum capricornutum to WP-F Smoke-Dosed

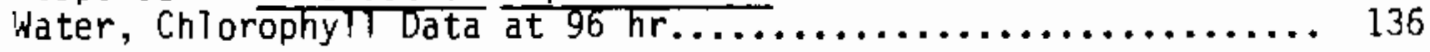

A.11. Comparison of Algal Toxicity of Three Batches of SGF No. 2 Fog $0 \mathrm{il}$ Based on Mean Chlorophylt Analys is at $96 \mathrm{hr} \ldots \ldots \ldots . . .137$

A.12. Responses of Selenastrum capricornutum to Vaporized fog $0 \mathrm{i}\}$,

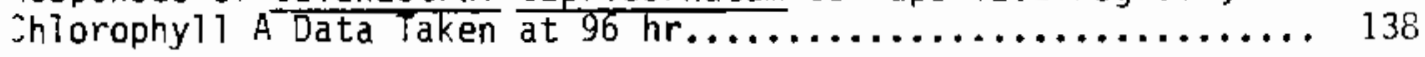

B.1. Yedia Used for Toxicity Testing........................ 139

B.2. Yedia Used to Grow Selenastrum capricornutum to Feed Daphnia nagna.................................................. 140

C.1. RP-BR Neutralization Tests with Daphnia magna in Well water, Burn RP-5 (Total $P=93 \mathrm{mg} / \mathrm{L}$ in Stock SoTution).............. 142

C.2. RP-BR Neutralization Tests with Daphnia magna in Reconstituted Soft Water, Burn RP-9 (Total P $=70 \mathrm{mg} / \mathrm{L}$ in Stock Solutions)..... 143

C.3. RP-BR Neutralization Test with Daphnia magna in Reconstituted Hard Water, Test 1 , Burn RP-15 TTot.aT $P=65.4 \mathrm{mg} / \mathrm{L}$ in Stock Solution).....

C.4. RP-BR Neutralization Tests with Daphnia magna in reconstituted Hard Water, Test 2, Burn RP-16 (Total P $=69.1 \mathrm{mg} / \mathrm{L}$ in Stock

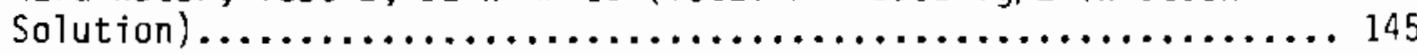

C.5. RP-BR Neutralization Tests with Daphnia magna in Reconstituted Very Hard Water, Burn RP-5 (TotaT $P=96.3 \mathrm{mg} / \mathrm{L}$ in Stock

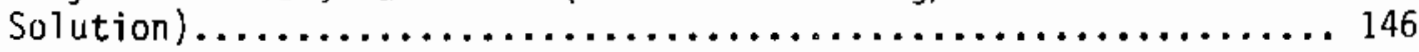

C.6. Cumulative Mortality of Daphnia magna to RP-8R Smoke-Dosed

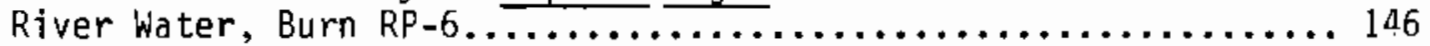

C.7. Cumulative Mortality of Hyallela azteca to RP-BR Smoke-Dosed

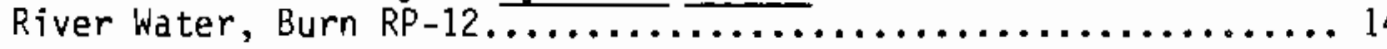




\section{LIST OF TABLES (Cont.)}

$\underline{\text { Page }}$

C.8. Acute Mortaility of Paratanytarsus dissimilus to RP-BR

Smoke-Dosed Water, Burn RP-12......................... 147

C.9. Cumulative Mortality of Hexagenia Exposed to RP-BR Smoke-Dosed

River Water, Burn RP-13,.......................... 148

C.10. Cumulative Mortality of Pimephales promelas Exposed to RP-BR Smoke-Dosed River Water (10 Fish/Aquarium), Burn RP-10......... 148

C.11. Cumulative Mortality of Salmo gairdneri Exposed to RP-BR Smoke-Dosed River water, Burn RP-16..................... 149

C.12. Cumulative Mortality of Ictalurus punctatus Exposed to RP-BR. Smoke-Dosed Water, Burn RP-11......................... 149

C.13. Cumulative Mortality of Lepomis macrochirus Exposed to RP-BR Smoke-Dosed Water, Burn RP-12...................... 150

C.14. Neutralization Test with Daphnia magna in Well Water, Burn

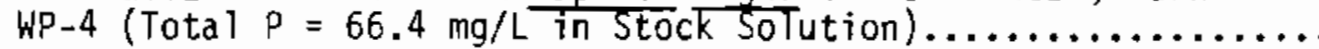

C.15. WP-F Neutralization Test with Daphnia magna in Reconstituted Soft Water, Burn WP-4 (Total $P=66.4 \mathrm{mg} / L$ in Stock Solution)... 152

C.16. WP $\rightarrow F$ Neutralization Tests with Daphnia magna in Reconstituted Hard Water, Burn WP-10 (Total $P=88.6 \mathrm{mg} / \mathrm{L}$ in Stock Solution).. 153

C.17. WP-F Neutralization Test with Daphnia magna in Reconstituted Very Hard Water, Burn WP-7 (Total $P=\overline{125 \mathrm{mg}} / \mathrm{L}$ in Stock

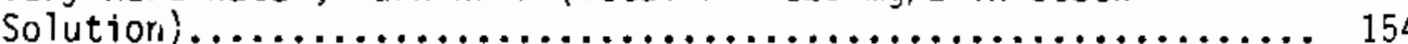

C.18. Cumulative Mortality of Daphnia magna to WP-F Smoke-nosed River water, Burn WP-16.......................... 155

C.19. Mortality of Hyallela azteca Exposed to WP-F Smoke-Dosed River Water, Burn WP-14......................... 155

C.20. Mortality and Case Building Data for Paratanytarsus dissimilus Exposed to WP-F Smoke-Dosed River Water, Burn WP-14.......... 156

C.21. Cumulative Mortality of Hexagenia exposed to WP-F Smoke-Dosed

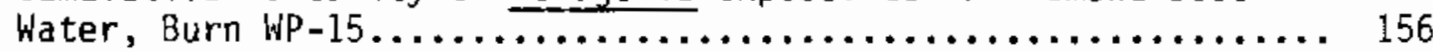

C.22. Cumulative Mortality of Pimephales promelas Exposed to WP-F Smoke-Dosed River Water, Burn WP-14 ..................... 157 


\section{LIST OF TABLES (Cont.)}

Page

C.23. Cumulative Hortality of Salmo gairdneri Exposed to WP-F Smoke-Dosed River Water, Burn WP-15................... 157

C.24. Mortality of Ictalurus punctatus to WP-F Smoke-Dosed River

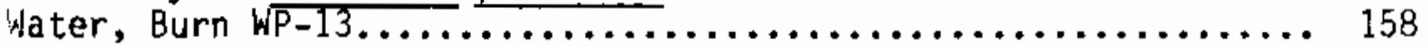

C.25. Jumulative Mortality of Lepomis macrochirus Exposed to WP-F Smoke-Dosed River Water, Burn Wp-16................... 158 


\subsection{INTRODUCTION}

The U.S. Army uses several different materials to generate smoke screens during military maneuvers. Three of the materials currently used are red phosphorus-butyl rubber (RP-BR), white phosphorus-felt (WP-F) and SGF (smoke generator fuel) No. 2 Fog $0 i 1$. The phosphorus-based obscurants are used in incendiary devices that are deployed in shells (WP-F) or in canisters (RP-BR). Fog oil smoke screens are produced with portable generators, such as the M3A3.

Use of obscurants during routine training operations may result in the contamination of bodies of water. To assess potential environmental hazards, researchers at Pacific Northwest Laboratory evaluated the acute toxicity of RP-BR, WP-F, and fog oil obscurants to nine different aquatic organisms. The principal vector of exposure involved the generation of smoke screens and the subsequent deposition of their constituents into a body of water. Spillage of fog oil directly into a body of water also constituted a direct vector of exposure. Indirect routes of exposure included the deposition of smoke screen constituents onto vegetation and soil followed by precipitation and runoff into a body of water.

The research project was divided into two phases. In Phase I, suitable dosing methods were developed for introducing the materiais into water. In addition, appropriate chemical analyses were developed for monitoring the materials in water. Several toxicity tests with Daphnia magna were conducted to investigate the influence of aging and the buffering capacity of water on the toxicity of the phosphorus-based materials. The effects of photolysis on the chemistry and toxicity of bulk and vaporized fog oils were also evaluated.

In Phase II, a battery of screening tests and definitive toxicity tests were performed on nine different species of freshwater aquatic organisms. 


\subsection{METHODS}

\subsection{TEST MATERIALS}

Three different materials were tested in this project: red phosphorus-butyl rubber (RP-BR), white phosphorus-felt (WP-F), and SGF (smoke generator fuel) No. 2 fog oil.

The RP-BR pellets and the WP-F wedges were obtained from 0ak Ridge National Laboratory. The RP-BR pellets were $95 \%$ RP and $5 \%$ BR. The pellets had a $1.25 \%$ coating of an insulating oil and $1 \%$ talc for optimum field performance. The WP-F wedges were originally removed from a munition supplied to Oak Ridge National Laboratory for a previous study. The RP-BR was stored dry and the WP-F wedges were stored in distilled water.

The U.S. Army supplied PNL with three drums (batches) of SGF No. 2 fog oil Table 1). Five one-gallon amounts of each batch of fog oil were

TABLE 1. PROJECT IDENTIFICATION OF THREE BATCHES OF SGF NO. 2 FOG OIL

\begin{tabular}{|c|c|c|}
\hline Batch & Barrel Designation & Amount \\
\hline Batch 1 & $\begin{array}{l}\text { F62 } \\
\text { Fog } 0 \text { i } \quad M i 1 \text { F-12070A \& AM1 } \\
\text { Type SGF-2 } \\
9150-00-261-7895 \\
\text { Mar } 80 \text { Batch } 984 \\
\text { DLA } 600-80-C \text { C } 0829\end{array}$ & $\begin{array}{l}\text { 39 gal. } \\
\text { (open drum, oil was } \\
\text { brown) }\end{array}$ \\
\hline Batch 2 & $\begin{array}{l}\text { Fog } 0 \text { il } \\
\text { MiI F-12070A \& AM1 } \\
\text { Type SGF-2 } \\
9150-00-261-7895 \\
\text { Sep } 82 \text { Lot F-2-9-18 } \\
\text { OLA } 600-82-C-1478\end{array}$ & $\begin{array}{l}\text { 33 gal. } \\
\text { (open drum, oil was } \\
\text { yellow) }\end{array}$ \\
\hline Batch 3 & $\begin{array}{l}\text { F-62 } \\
\text { Fog 0iT } \\
\text { MIL-F 12070B } \\
\text { Type SGF-2 } \\
\text { g150-00-261-7895 } \\
\text { Lot \#1 } \\
\text { DLA Coo-83-C-1284 } \\
\text { Date MFD } 7-83\end{array}$ & $\begin{array}{l}55 \text { gal. } \\
\text { ( fuit unopened drum, } \\
\text { oi? was transparent } \\
\text { like mineral oil) }\end{array}$ \\
\hline
\end{tabular}


transferred to a clean amber bottle for storage. The air space in the bottles was purged with $\mathrm{N}_{2}$, and then the bottles were refrigerated.

The $\mathrm{N}_{2}$ was replaced each time fog oil was removed from the bottles. The drums were also purged of air with $\mathrm{N}_{2}$ and refrigerated.

\subsection{AEROSOL GENERATION}

This section describes the methods used to generate aerosols for the preparation of exposure solutions. Aerosol generations (vaporizations) of fog ofl are identified as F0-1 through F0-4. Combustions of WIP-F and RP-BR are identified as WP-1 through WP-16 and RP-1 through RP-16. The combustions are routinely referred to as "burns."

\subsubsection{Red Phosphorus-Butyl Rubber and White Phosphorus Felt}

The same system was used to generate smoke from white phosphorus-felt and red phosphorus-butyl rubber (Figure 1). Pellets of RP-BR and cubes ( 1 $\left.\mathrm{cm}^{3}\right)$ of WP-R were ignited by passing them through a propane flame and then dropping them onto a bed of sand in a bell jar where they burned to completion. Since these burns were typically of short duration, this task was performed manually. The smoke was drawn from the bell jar through a $36-\mathrm{ft}^{3}$ buffer chamber by a vacuum pump at a flow rate of approximately $100 \mathrm{~L} / \mathrm{min}$. Chamber airflow was monitored by measuring the pressure drop across an orifice in the chamber exhaust 1 ine. The buffer chamber smoothed out fluctuations in the monitored smoke concentration caused by the intermittent addition of pellets. Smoke from the chamber was directed to either four 54-L carboys containing the test water or to exhaust, depending on the position of the system's three-way ball valve. Flow rates through the four carboys were about $25 \mathrm{~L} / \mathrm{min}$ each for a total of $100 \mathrm{~L} / \mathrm{min}$. Flow rates were calibrated using a singer dry test meter.

The concentration of phosphorus smoke in the buffer chamber was determined with a GCA RAM-1 real-time aerosol monitor connected to an in-line TSI model 3302 100:1 diluter. Flow through the RAM/diluter combination was maintained at $5.0 \mathrm{~L} / \mathrm{min}$ using the RAM's internal flowmeter. The aerosol monitor was calibrated to provide data on the phosphorus smoke concentration by comparing the monitor's output obtained on an analog strip chart recorder to that obtained gravimetrically using filter pad grab samples (Figure 2). Gelman type $A E$ 25-inm glass fiber filters were desiccated, weighed, and inserted into an open-faced filter holder positioned centrally inside the exposure chamber. Several 1- to 2-min grab samples were drawn at $1.0 \mathrm{~L} / \mathrm{min}$ through the filters. The filters were then redesiccated and reweighed. Calibration data for the aerosol monitor were calculated by dividing the net aerosol mass on the filter by the calibrated volume of air pulled through the filter.

In a typical phosphorus burn, WP-F cubes or RP-BR pellets were ignited and placed in the smoke generator until the smoke concentration in the buffer chamber reached maximum levels as recorded by the aerosol monitor. 


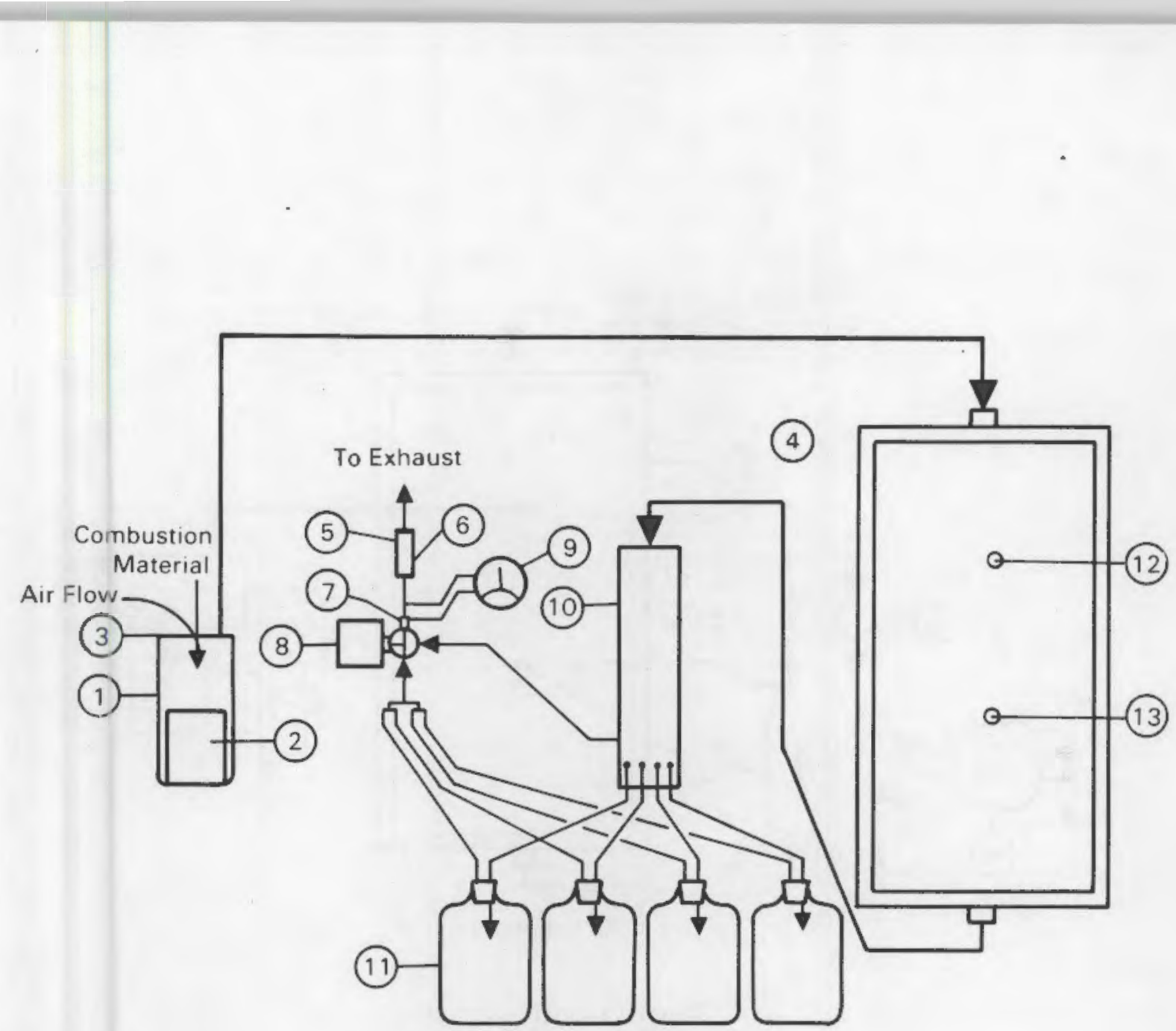

1. Generator Bell Jar

2. Sand Filled $\mathrm{S} / \mathrm{S}$ Beaker

3. Bell Jar Lid

4. Standard 8attelle/Hazleton $1.2 \mathrm{~m}^{3}$ Animal Exposure Chamber

5. Air Actuated Vacuum Pump

6. Regulated Air Input

7. Airflow Restriction
8. 3-Way Vaive
9. Magnehelic Vacuum Gauge
10. Manifold (3.5 Liter Volume)
11. Carboys
12. Monitor Port
13. Calibration Port

Figure 1. Phosphorus Smoke Generation System.

The smoke was then diverted to the four 54-L carboys containing the test water, where it settled into the water and onto the sides of the carboys. When the exposure was completed (typically after 10 or 15 min of burn time), the four 54-L carboys were by-passed. The burn was terminated and the four 54-L carboys were removed from the smoke generator system, capped, and placed on their sides for $1.5 \mathrm{hr}$ to allow the smoke to settle into the water and onto surfaces of the carboys. After $1.5 \mathrm{hr}$, the sides of the carboys were rinsed by rolling and inverting the carboys. Gravimetric grab sample analysis confirmed that no smoke remained in the head space above the water after $1.5 \mathrm{hr}$. 

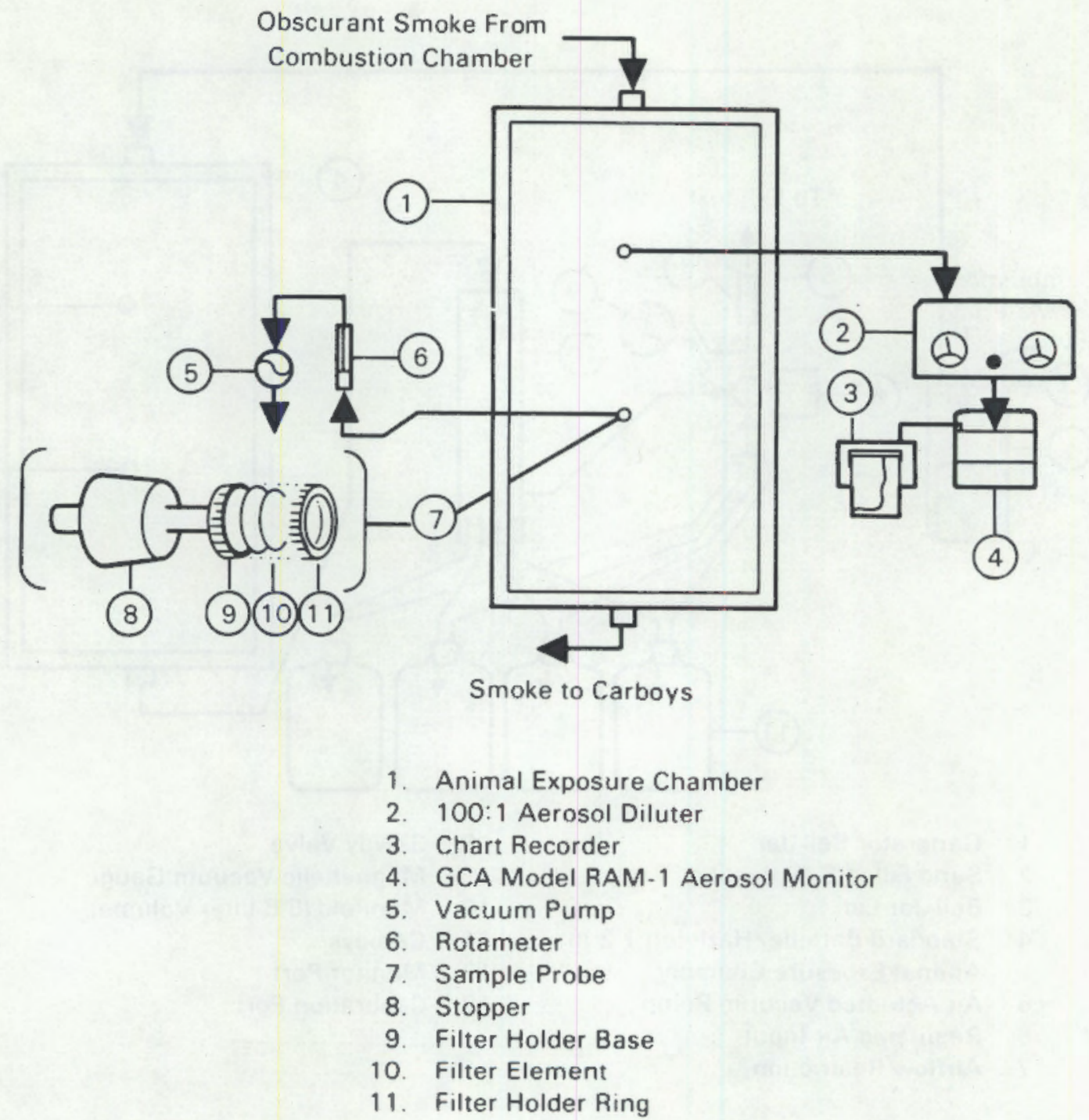

Figure 2. Filter Sampling Device for Phosphorus Smoke Generation System.

Studies with fish or Hexagenia required larger volumes of water than could be had been exposed in 54-L carboys. This necessitated larger volumes of phosphorus smoke and, hence, a larger smoke exposure chamber than could be provided by the four 54-L carboys. A special 760-L (200-gal) Fusion Rubbermaid Carboy (Pt. No. 1185, Statesville, North Carolina) was substituted for the $36-\mathrm{ft}^{3}$ buffer chamber shown in Figure 1 . This chamber served as a buffer chamber, sampling chamber, and smoke exposure chamber

\footnotetext{
Trademark of the Rubbermaid Co.
} 
for the test water. In some burns, the four 54-L carboys were retained in the system to permit their simultaneous exposure to the phosphorus smoke downstream of the $760-\mathrm{L}$ exposure chamber during selected experiments.

\subsubsection{SGF No. 2 Fog $0 i 1$}

The system used to generate fog oil vapors is illustrated in Figure 3. Fog oil was introduced at the rate of $5.8 \mathrm{~mL} / \mathrm{min}$ by an FMI ceramic

pulsatile laboratory pump into the fog $0 i 1$ vapor generator (Figure 4). The fog oil was flash-vaporized on contact with a $600^{\circ} \mathrm{C}$ vycor heater rod. Heat tape maintained the generator at $300^{\circ} \mathrm{C}$ downstream of the fog oil introduction port in order to control the rate of condensation of the newly generated fog oil vapor. A $4.0 \mathrm{~L} /$ min stream of nitrogen was used to flush the fog oil vapor from the generator into the dilution air stream. Nitrogen was used instead of air to eliminate the explosion hazard involved with generating a high concentration of fine oil vapor within an enclosed, high-temperature generator. The fog oil vapor and the air stream used to dilute the mixture was pulled through a standard aerosol exposure chamber by a transvector air flow amplifier at $10 \mathrm{ft}^{3} / \mathrm{min}$. Chamber air flow was monitored by measuring the pressure drop across an orifice in the chamber exhaust line.

The concentration of fog oil smoke in the chamber was determined using a GCA RAM-1 real-time aerosol monitor connected to an in-line TSI model 3302 100:1 diluter. Flow through the RAM/diluter combination was maintained at $5.0 \mathrm{~L} / m i n$ using the RAM's internal flowmeter. The aerosol monitor was calibrated to provide data on the fog oil vapor concentration by comparing the monitor's output obtained on an analog strip chart recorder to the results obtained gravimetrically using filter pad grab samples. Pre-weighed Gelman type AE 25-mm glass fiber filters were inserted into an open-faced filter holder positioned centrally inside the exposure chamber. Several 1- to 2-min grab samples were drawn at a flow rate of $1.0 \mathrm{~L} / \mathrm{min}$ through the filters. The filters were then reweighed. Calibration data for the aerosol monitor were calculated by dividing the net fog oil mass on the filter by the volume of air pulled through that filter.

Four vaporizations of fog oil, three with Batch 1 fog 0 il (F0-1 through $\mathrm{FO}-3$ ) and one with Batch 3 (FO-4) were conducted. The first vaporization, $\mathrm{F0}-1$, was generated under $100 \% \mathrm{~N}_{2}$. The other vaporizations, $\mathrm{FO}-2, \mathrm{FO}-3$ and $\mathrm{FO}-4$, were generated in $4 \%$ excess air.

A total of 13 stainless steel, sterilized animal excreta collect pans were positioned inside the exposure chamber to catch the fog oil as it settled. In experiments $\mathrm{FO}-1$ and $\mathrm{F} 0-4$, the chamber was allowed to reach maximum fog oil concentration, at which time the fog oil generator was turned off and the chamber sealed to allow time for the fog oil to settle onto the catch pans. Vaporization FO-1 consisted of five runs of approximately 15 minutes each, separated by an interval of approximately $1 \mathrm{hr}$ to allow the more massive droplets to settle. Vaporization F0-4 consisted of 


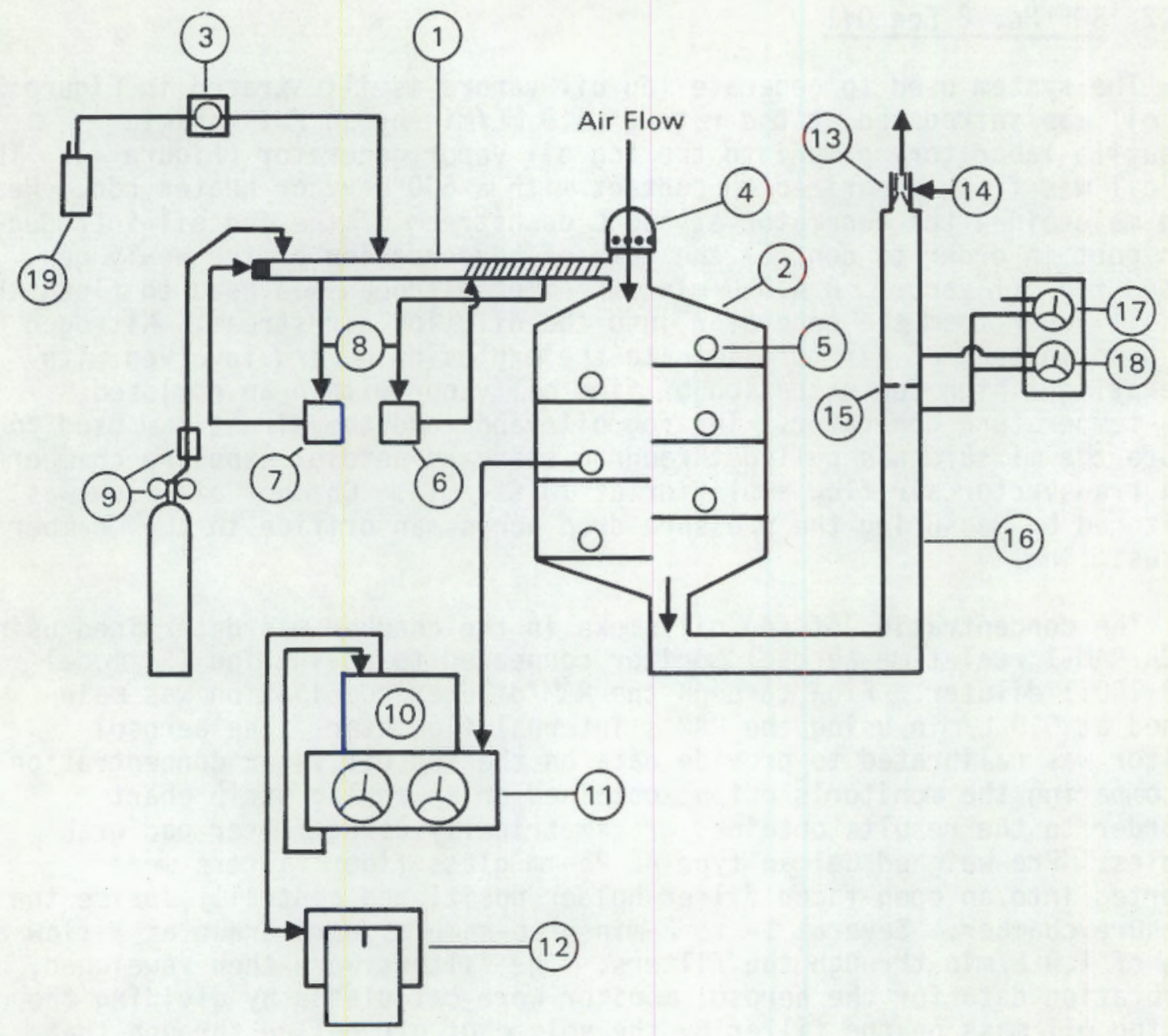

1. Fog Oil Generator

2. Standard Battelle/HAZELTON $2.4 \mathrm{M}^{3}$ Animal Exposure Chamber

3. FMI Junior (Ceramic) Pulsatile Laboratory Pump; Variable Flow

4. Variable Inlet Flow Restrictor

5. Chamber Sample Port

6. Temperature Controller for Heat Tape; with Temperature Readout

7. Same as \#6 but for Rod Heater

8. Temperature Controller Thermocouples
9. Regulated Nitrogen with Flow Meter

10. GCA Model RAM-1 Aerosol Monitor

11. TSI Model 3302 100:1 Aerosol Diluter

12. Chart Recorder

13. Air Driven Vacuum Pump

14. Regulated Air Input

15. Exhaust Line Orifice

16. Chamber Exhaust Line

17. Chamber Vacuum Monitor ( ( $(-2)-0-2 \mathrm{~cm} \mathrm{HOH})$

18. Chamber Flow Monitor ( $(-2)-0-2 \mathrm{~cm} \mathrm{HOH})$

19. Oil Reservoir

Figure 3. Fog 0il Vapor Generating and Collection System. 


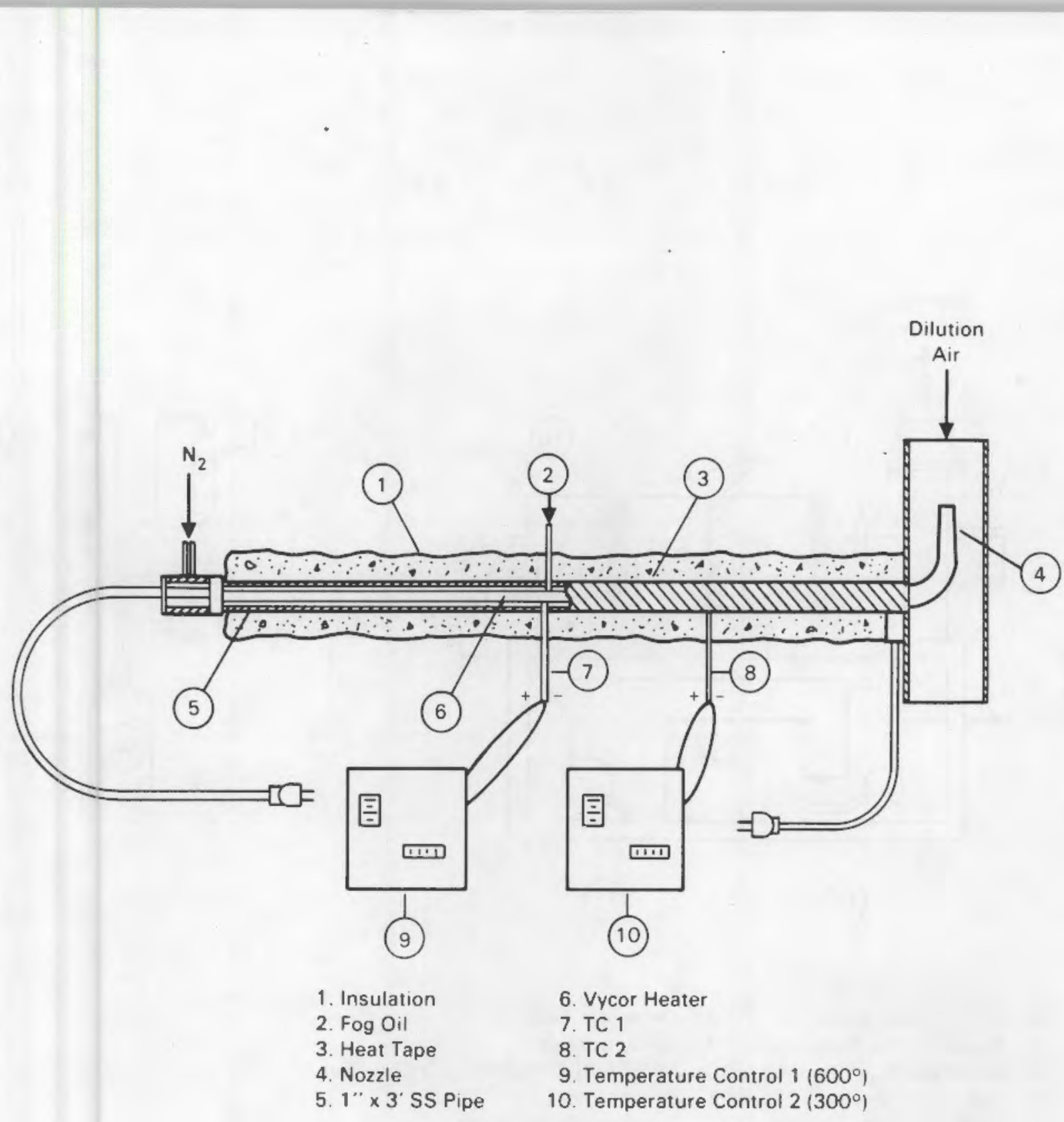

Figure 4. Fog 011 Vapor Generator.

1130 -min runs, each separated by at least $1 \mathrm{hr}$ to allow for settling. At the end of each series of runs, the fog oil collected on the catch pans was scraped off with glass microscope slides (FO-1) or Teflon squeegies (F0-4) into volumetrically calibrated glass containers. A total of $80 \mathrm{~mL}$ of fog $0 i 1$ was collected from all 13 catch pans for experiment $\mathrm{F0}-1$, and $1100 \mathrm{~mL}$ was collected for $\mathrm{FO}-4$.

The system used to generate fog oil vapor for $\mathrm{FO}-2$ and $\mathrm{FO}-3$ is shown in Figure 5. Fog oil vapor was generated in the manner described for $\mathrm{F} 0-1$ but with minor changes. For these trials, $3.2 \mathrm{~L} / \mathrm{min}$ of compressed air was mixed with $46.8 \mathrm{~L} / \mathrm{min}$ of $\mathrm{N}_{2}$ to provide approximately $4 \%$ excess air before the mixture entered the generator. The rate at which oil flowed into the 


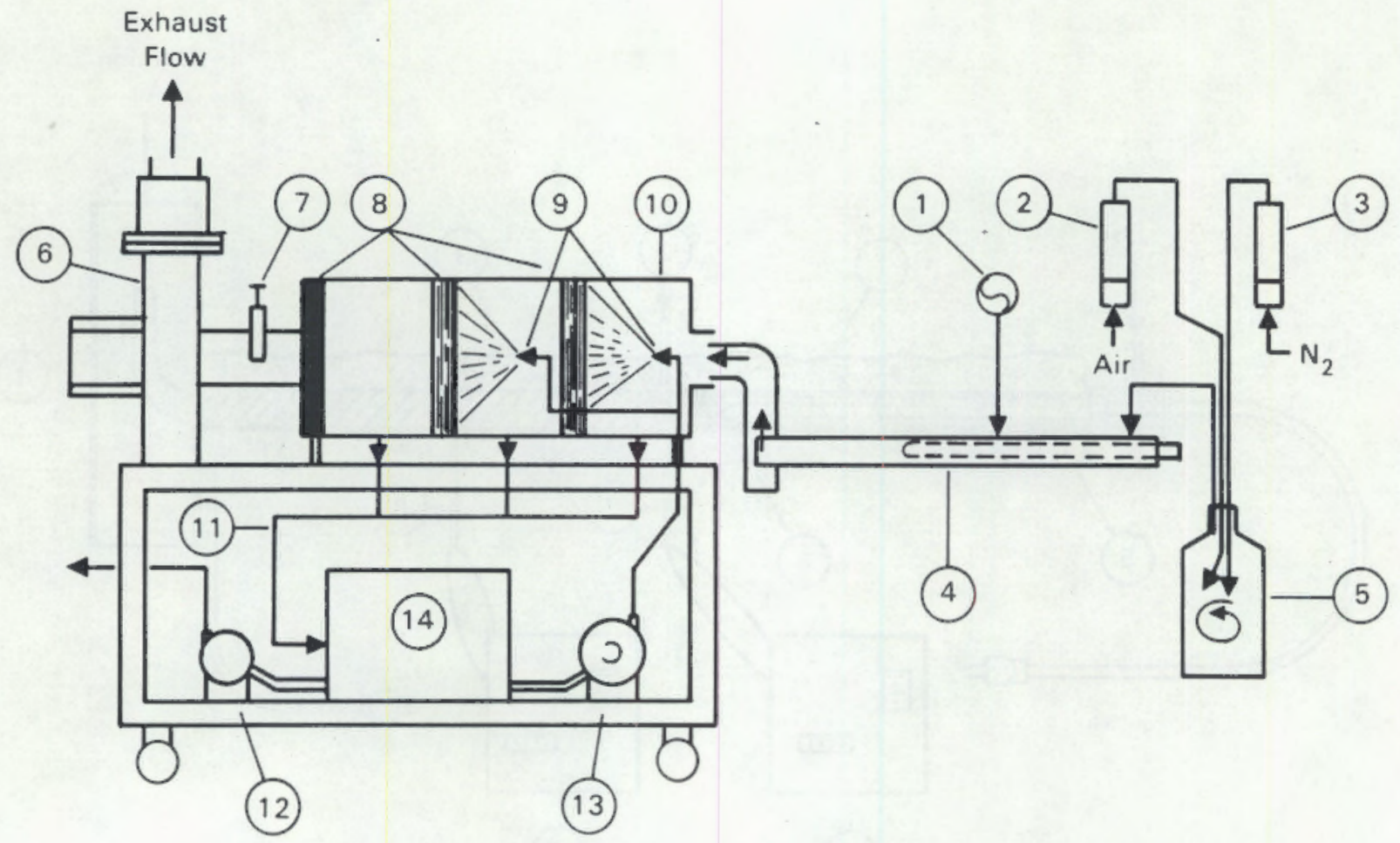

1. Oil Metering Pump

8. De-mister Pads

2. Generator Air Rotameter

9. Spray Nozzles

3. Generator $\mathrm{N}_{2}$ Rotameter

4. Fog Oil Generator

10. MYSTAIRE Laboratory Air Scrubber

5. Air- $\mathrm{N}_{2}$ Mixing Chamber

6. Blower Fan

11. Drain Lines

12. Reservoir Drain Pump

7. Airflow Control Gate

13. Spray Pump

14. Solution Reservoir

Figure 5. Fog $0 i l$ Vapor Collection System with MYSTAIRE ${ }^{\circ}$ Scrubber.

generator was reduced from $5.8 \mathrm{~mL} / \mathrm{min}$ to $2.2 \mathrm{~mL} / \mathrm{min}$ to 1 ower the concentration of vapor and thus reduce the explosion potential caused when oxygen in the air was introduced into the fog oil generator.

Methods used to collect fog oil vapor in $\mathrm{FO}-2$ and $\mathrm{F} 0-3$ differed from the catch pan settling methods used in F0-1 and F0-4. A MYSTAIRE laboratory scrubber was used to pull the fog oil vapor from the generator in

Trademark of the Heat Systems-U1trasonic Inc., Framingdale, NY 
experiments $\mathrm{FO}-2$ and $\mathrm{FO}-3$. This laboratory scrubber uses two fine mist sprays connected in series to efficiently ( $-90 \%)$ scrub particles from the air stream generated by a vacuum pump. In F0-2, the fog oil was collected in the recirculating scrubbing water for analysis. In F0-3, the fog $0 i 1$ was collected on a loosely packed glass-wool filter inserted between the fog oil generator and the MYSTAIRE laboratory scrubber.

\subsection{ANALYSIS OF PHOSPHORUS COMBUSTION PRODUCTS}

Phosphorus combustion products were analyzed by two primary methods: inductively coupled plasma (ICP) emission spectrometry and ion chromatography.

\subsubsection{ICP Analysis of Total Phosphorus}

The total phosphorus in solutions generated by the burning of WP-BR or WP-F was determined with a Model 975 Jarrel1-Ash (Division of Fisher Scientific; now Allied Analytical Systems) inductively coupled plasma (ICP) emission spectrometer. Aqueous samples were analyzed without modification (i.e., no acid added) and normally did not require filtration.

The Jarrell-Ash ICP uses two-point calibration. Normal setup uses $0.0 \mathrm{ng} / \mathrm{L} . \mathrm{P}$ (water blank) and a $10.0 \mathrm{mg} / \mathrm{L} \mathrm{P}$ standard. An internal reference standard is not used since viscosity is not nomally a problem with these samples. No on-peak spectrat correction of any significance is made for $P$, though the actual program used is proprietary to Jarrell-Ash. No off-peak background correction is made. Drift in the ICP is controlled by running standards after approximately five samples. If the system has drifted any more than $3 \%$, the instrument is recalibrated and the last sample is rerun. Precision is expected to be about $\pm 50 \%$ at the detection 1 imit $10.1 \mathrm{mg} / \mathrm{L}$ for P), $\pm 10 \%$ at 5 times the detection limit, and $\pm 3 \%$ at 50 times the detection limit.

In addition to $P$ analysis, the ICP provided a scan of 32 other elemental concentrations simultaneously. This additional information was very helpful in monitoring solution preparations, in "debugging" smoke generation techniques, and in estimating the composition of precipitated material observed to form slowly in the harder waters.

\subsubsection{Ion Chromatography}

The lower oxyphosphoric-acid species were analyzed using a Dionex (Sunnyvale, California) model 16 Ion Chromatograph (IC) equipped with AG1 and AS1 separator columns and either a cation resin eluent-suppression column or a continually-regenerated fiber suppressor linked to a conductivity detector. Eluent was $3 \mathrm{mM} \mathrm{NaHCO} \mathrm{N}_{3}$ plus $2.4 \mathrm{mM} \mathrm{Na} \mathrm{CO}_{3}$. Phosphate and phosphite were resolved from other anions $\left(\mathrm{F}^{-}, \mathrm{Cl}^{-}, \mathrm{Br}^{-}, \mathrm{NO}_{3}{ }^{-}, \mathrm{SO}_{4}{ }^{-}\right)$in the water matrices. Detection limits were $0.02 \mathrm{mg} / \mathrm{L}$ for phosphate-P and $0.01 \mathrm{mg} / \mathrm{L}$ for phosphite-P. Hypophosphite co-eluted with $\mathrm{F}^{-}$and any other non-retained conductive species in the void volume, and so could only be 
estimated based on changes in the peak height for the samples versus the water blanks. Thus, detection of hypophosphite in reconstituted very hard water (Marking and Dawson 1973) would be approximately $0.03 \mathrm{mg} / \mathrm{L}$ as $\mathrm{p}$, whereds in well water the detection limit would be no better than $0.05 \mathrm{mg} / \mathrm{L}$ as P.

Continued analysis of stock and exposure solutions resulted in a loss of column efficiency and an increase in back pressure. The back pressure was presumably caused by binding of the higher polyphosphates onto the column in the basic system. Reasonable column recovery was attained by back-flushing with a series of acid and base washes $\left(0.1 \mathrm{~N} \mathrm{H}_{2} \mathrm{SO}_{4}, 0.1 \mathrm{~N}\right.$ $\mathrm{NaOH}, 0.2 \mathrm{~N} \mathrm{Na}_{2} \mathrm{CO}_{3}$ ).

Calibration of the IC depends on comparison to known standard dilutions and, therefore, is limited by the accuracy of the dilutions. Sufficient standards are run to "bracket" the sample concentrations. No matrix effects were evident for phosphate or phosphite. Precision variation in tandem replicates was $1 \%$ for $P 03_{4}^{3-}-\mathrm{P}$ at $4.3 \mathrm{mg} / \mathrm{L}$ level and no worse than $8 \%$ for $\mathrm{HPO}_{3}^{2}-\mathrm{P}$ at the $0.013 \mathrm{mg} / \mathrm{L}$ level.

Phosphate, phosphite, hypophosphite, and pyrophosphate solutions were prepared from reagent grade chemicals (MCB, Norwood, Ohio; MCB; Baker, Phillipsburg, New Jersey; and Fisher, Springfield, New Jersey

respectively). Tripolyphosphate was supplied by Monsanto (St. Louis, Missouri). Tetrapolyphosphate, hexammonium salt, and the type 5, 15, and 25 polyphosphate glasses were obtained from Sigma Chemical Company (St. Louis, Missouri). Cyclic trimetaphosphate was prepared according to Ballou (1981). Al1 other chemicals used were reagent grade.

\subsubsection{Phosphorus Speciation}

The separation scheme for polyphosphate speciation deviates slightly from the Yamaguchi et al. (1979) procedure. The procedure involves anion exchange using a high-salt eluent containing ethylenediamine tetracedic acid (EDTA) to complex any metals in the system, thereby slowing the depolymerization rate. The condensed phosphates are acid hydrolyzed and the resultant phosphate reacts to form a heteropoly blue complex with $M o(V-V I)$. Basic conditions used to separate condensed phosphates are listed in Table 2. Satisfactory results were obtained using a water bath $\left(94^{\circ} \mathrm{C}\right)$ to heat both the acid hydrolysis and the color development loops.

In initial work, we used $\mathrm{Na}_{3}$ EDTA eluents (pH 7.5) to increase the retention times of the linear polyphosphates. Under this system, however, $3 \mathrm{P}$ and 4P coeluted. Subsequently, we returned to the Yamaguchi et al. (1979) eluent system containing $\mathrm{Na}_{4}$ EDTA ( $\mathrm{pH} 10$ ). Using their system, we observed up to 23 linear polyphosphates and 3 metaphosphates in the samples we processed.

Under the high performance liquid chromatography (HPLC) conditions given, it is not likely that phosphite and hypophosphite would be resolved 
TABLE 2. CONDITIONS USED IN SEPARATION OF LINEAR AND CYCLIC CONDENSED PHOSPHATES

\author{
HPLC Conditions: \\ Resin - Hitachi \#2630 (a spherjcal anion exchange resin) \\ Column - $10 \cdot x 1 \mathrm{~cm}$ \\ Eluent $A-0.22 \mathrm{M} \mathrm{NaCl}+5 \mathrm{mN} \mathrm{Na}{ }_{4}$ EDTA (pH 10) \\ Eluent B $-0.53 \mathrm{M} \mathrm{NaCl}+5$ mis $\mathrm{Na}_{4}$ EDTA (pH 10) \\ Gradient $=$ Curve 5 , Waters 660 solvent programner \\ Flow rate $=1.1 \mathrm{~mL} / \mathrm{min}$ \\ Colorimetric Conditions: \\ Sample stream splitter percent $=30$ \\ Acid hydrolysis $-0.32 \mathrm{~mL} / \mathrm{min} 3.45 \mathrm{M} \mathrm{H}_{2} \mathrm{SO}_{4}$ \\ Aerosol 22 Solution $-0.10 \mathrm{~mL} / \mathrm{min} 0.05 \%$ solution \\ Resample rate $-0.42 \mathrm{~mL} / \mathrm{min}(\sim 57 \%$ of hydrolysis mix) \\ Molybdate Solution $-0.32 \mathrm{~mL} / \mathrm{min} 8.1 \mathrm{mM}\left(\mathrm{NH}_{4}\right)_{6} \mathrm{Mo}_{7} \mathrm{O}_{24} \cdot 4 \mathrm{H}_{2} \mathrm{O}$ in $0.6 \mathrm{~N}$ \\ $\mathrm{H}_{2} \mathrm{SO}_{4}$ \\ Ascorbic Acid Solution - $0.23 \mathrm{~mL} / \mathrm{min} 0.1 \mathrm{M}$ ascorbic acid in $5 \%(\mathrm{~V} / \mathrm{V})$ \\ acetone plus $0.05 \%$ aerosol 22 solution \\ Detection - $660 \mathrm{~nm}$
}

from phosphate. Even if they could be resolved, however, the phosphite and hypophosphite would not be oxidized to phosphate in the hydrolys is scheme and, consequently, would not be detected colorimetrically. Ultraviolet (UV) enhanced oxidation prior to acid hydrolysis would elininate the detection problem, but the high concentration of chloride in the column effluent would slow the oxidation process. Since the ion chromatographic procedure is much faster and the inorganic phosphorous species are better resolved, it has remained the principal analytical method for the bulk of the samples. In practice, hypophosphite has been insignificant $(<0.1 \%)$ and will not be reported. Although considerable improvements in the time required for HPLC analysis have been made by Brazell, Holmberg and Moneyhun (1984), resolution of the metaphosphates and of the higher polyphosphates $(>13 p)$ was somewhat diminished in the faster procedure. Work in this project was conducted using the slower Yamaguchi method only.

\title{
2.3.4. Other Analytica] Techniques
}

Solvent extractions of WP-F stock solutions were performed, with slight variation, according to the method described by Lai (1979). Based on data in that report, extraction of white phosphorus into benzene (10:1 water to benzene ratio) was expected to be about $93 \%$ complete in $1 \mathrm{hr}$, and $100 \%$ in $3 \mathrm{hr}$; hydrolys is and back extraction into $8 \mathrm{M} \mathrm{HNO}_{3}$ (10:1 benzene to acid ratio) would be $99 \%$ complete in $1 \mathrm{hr}$. 
Initial extractions were performed using 10:1 and 5:1 extraction ratios for 1 to 3 hours, followed by back extraction at a 10:1 ratio with $6 \mathrm{M} \mathrm{HNO}_{3}$. Hydrolysis-evaporation of the benzene layers after back extraction showed no detectable remaining $P$ by ICP analysis (equivalent to $0.02 \mathrm{mg} / \mathrm{L} P$ detection limit in original aqueous phase). Efficiency of the initial benzene extraction step could not be otherwise checked, since no GC procedure had been established for WP analysis. We assumed efficiency was similar to that quoted by Lai (1979).

Later extractions were modified to a 20:3 water to benzene ratio with contact for $2 \mathrm{hr}$, followed by water rinse and a $10: 1$ benzene to $6 \mathrm{MHNO}_{3}$ ratio and contact for about $1.5 \mathrm{hr}$.

A brief study of feasibility of thin layer chromatography (TLC) applications was based on methods of Ballou (1981) and Katz et al. (1981). Results of the TLC study were less than satisfactory, due to both extended operator time and lack of clarity in the resulting plates. Therefore, the TLC methods were discontinued from routine use.

Titration of the acid endpoints was done using a system composed of REC80 servograph, REA161 titrigraph module, REA260 derivative unit, ABU80 autoburette, TTT80 titrator, and PHM82 $\mathrm{pH}$ meter (Radiometer, Copenhagen). The first acid inflection was corrected for the partial neutralization caused by the carbonate content of the sample. The titration procedure indicated the presence of polyphosphate and that the species could not be entirely metaphosphates. Further prediction of the species in a mixture would have been little better than conjecture in the absence of actual speciation, so the titration procedure was not continued on a routine basis.

\subsection{ANALYSIS OF SGF NO. 2 FOG OIL}

This section describes the methods used to analyze bulk fog oil and to monitor oil-water mixtures (OWM) of fog oil. High performance liquid chromatography (HPLC) and analysis of total organic carbon were briefly investigated for monitoring oil-water dispersions (see Section 3.4).

\subsubsection{Infrared Analysis of Total 011}

Standard solutions of SGF No. 2 Fog 0 il at various concentrations were prepared in carbon tetrachloride $\left(\mathrm{CCI}_{4}\right)$. Infrared absorbence of these solutions was measured at $2927 \mathrm{~cm}$ and a calibration curve of absorbence versus concentration was prepared. Carbon tetrachloride was used to extract fog oil from acidified oil-water mixtures (OWM), and the resulting extracts were analyzed for infrared absorbence (IR) at $2927 \mathrm{~cm}$. Least souares linear regression analysis of the calibration data yielded a 1 inear fit $\left(R^{2}=0.997\right)$ with the equation $Y=0.0014+0.0023 X$. The concentrations of fog $0 i 1$ in each $\mathrm{OHM}-\mathrm{CCl}_{4}$ extract were determined by comparing the IR absorbence of the extract with the corresponding absorbence and fog 
oil concentrations on the calibration curve. Concentrations of oil in the aqueous samples were then calculated by applying concentration factors accounting for volume differences between originat aqueous samples ( $500 \mathrm{~mL}$ ) and $\mathrm{CCl}_{4}$ extracts.

Extraction efficiency of $\mathrm{CCl}_{4}$ was indirectly determined by comparative studies of the IR absorbence of fog oil dissolved in $\mathrm{CCl}_{4}$. The IR absorbence was determined in $10 \mathrm{~mL}$ volumes of the fog $0 \mathrm{O}_{1} \mathrm{CCl}_{4}$ solutions. The 10-mL. fog oil- $\mathrm{CCl}_{4}$ solutions were then mixed with $500 \mathrm{~mL}$ of acidified distilled $\mathrm{H}_{2} \mathrm{O}$ to simulate the extractions of fog oil from exposure solutions. IR absorbence indicated a recovery of $103 \% \pm 2.7 \%$. A Beckman Acculab infrared spectrophotometer was used for all measurements. Performance of the spectrophotometer was checked before each use with a standard made of polystyrene film.

\subsubsection{Gas Chroma tography}

High resolution gas chromatography (GC) with flame ionization detection (FID) was used to measure saturated and aromatic hydrocarbon and phenol concentrations in bulk oil and in OWMs of SGF No. 2 Fog 0i1. Bulk fog oil sampies were diluted with hexane to a concentration of about $10 \mathrm{mg} / \mathrm{mL}$. One-liter volumes of $0 \mathrm{WMs}$ were acidified and extracted twice with two $25-\mathrm{mL}$ volumes of methylene chloride. The two extracts were combined, reduced to $1 \mathrm{ml}$ under nitrogen, and the methylene chloride was exchanged for hexane. Saturated hydrocarbon fractions and aromatic hydrocarbon fractions were isolated from other fog oil components by passing the oil-in-hexane solutions through a $25-\mathrm{cm}-1$ ong by $1.25-\mathrm{cm}$-diameter glass column packed with Davidson 100 to 200 mesh silica gel that had been activated at $150^{\circ} \mathrm{C}$ (Warner 1976). Saturated hydrocarbons were eluted with $40 \mathrm{ml}$ of hexane. The aromatic fraction was then eluted with $87 \mathrm{~mL}$ of $20 \%$ methylene chloride in hexane. Both fractions were reduced in volume under nitrogen to approximately $1 \mathrm{~mL}$ for GC analysis.

Hydrocarbon components were quantified using the internal standard method. The gas chromatograph was calibrated by determining detector response factors for concentrations of known saturated and aromatic hydrocarbon standards. These response factors were compared to the detector response for an internal standard added to both standards and samples. Hexamethylbenzene was used as a standard for aromatic hydrocarbons and $2,6,10$-trimethyldodecane was used for saturated hydrocarbons.

The fog oil and OWMs were analyzed for phenols. Phenols were extracted from $0 i 1$ samples into $0.1 \mathrm{~N} \mathrm{NaOH}$ and acetylated by addition of acetic anhydride to the aqueous extract. Phenols present in 0wMs were acetylated with acetic anhydride after a concentrated NaOH solution had been added to give a final concentration of $0.1 \mathrm{~N} \mathrm{NaOH}$. Phenol acetates were extracted from aqueous solution into $4 \mathrm{~mL}$ of hexare. Hexane extracts were concentrated and amended with $n$-dodecane as an internal stardard. Detector response factors were determined for authentic phenol standards 
amended to $0.1 \mathrm{~N} \mathrm{NaOH}$, acetylated, and extracted by the same method used for samples.

A Hewlett-Packard model 5840 or 5880 gas chromatograph fitted with a 60-m DB-5 fused silica bonded capillary column (J \& W Scientific, Inc.) was used for GC analysis. Chromatographic conditions included split injection of a $2-\mu \mathrm{L}$ sample (10:1 split ratio). Following sample injection, the chromatograph oven temperature was maintained at $65^{\circ} \mathrm{C}$ for 4 min and then programmed to increase at $4^{\circ} \mathrm{C} / \mathrm{min}$ to $260^{\circ} \mathrm{C}$ with a 20 min hold at $260^{\circ} \mathrm{C}$.

\subsubsection{Photolysis of Fog 0ils}

Batch 1 butk and vaporized (FO-4) fog cils were used in the photolys is studies. Preliminary experiments were designed 1) to determine the optimum conditions for irradiation, and 2) to prepare photolyzed material for preliminary chemical and toxicity testing. Two samples of Batch 1 fog oil one vaporized (F0-4), and the other bulk, were tested. Photolys is was conducted in a flat-bottomed circular quartz container (74-mm diameter) covered with a quartz plate and kept at $20^{\circ} \mathrm{C}$ with a cooling plate. The quartz was transparent to light of wavelength 200 to $800 \mathrm{~nm}$. A solar simulator (Oriel model 6720), fitted with a filter to match the solar spectrum of light striking the earth at 90 degrees, was adjusted using a pyranometer such that the intensity striking the surface of the exposed oit was equal to $1.36 \mathrm{~kW} / \mathrm{m}^{2}$, the maximum intensity of sunlight striking the earth surface. Five milliliters of oil, forming a $0.116-\mathrm{cm}$ Tayer in the apparatus, were exposed for each experiment.

As exposure of oils continued, the course of the reaction of the oit was monitored by visual inspection and by determining the number of free radicals generated by the radiation. Free radicals were monitored with a Varian electron-spin resonance spectrometer that had been caljbrated with the stable free radical $\alpha, \alpha^{1}$-diphenylpicrylhydrazyl.

\subsubsection{Analysis of Photolyzed Fog 0 il}

Generally, the methods used to analyze photolyzed fog oil and 0WMs prepared from photolyzed fog oil were similar to the methods described previously. Both UV and GC analyses were slightly modified, however.

\section{UV Analysis}

UT traviolet absorbence spectra were determined for hexane extractions of the photolyzed oils. Stock solutions (OWMs) were extracted with isooctane for anaiysis of total oil. A Beckman DB-25 spectrophotometer was used to monitor and record UV absorbence.

\footnotetext{
Trademark of the Oriel Corporation, Stratford, Connecticut.
} 
GC Analysis

A 30-meter $\times 0.25 \mathrm{~mm}$ DB-5 nonpolar bonded phase capillary column (J) \& W Scientific) was used to separate water soluble components in the photolyzed OWH by GC. The instrument was linked to a Hewlett-Packard Model $5970 \mathrm{~A}$ mass-selective detector to identify selected components.

\subsection{CULTURE AND CARE OF TEST ORGARISMS}

This section discusses characteristics of the dilution water used during Phases I and II of the project and the methods used to cutture test organisms.

\subsubsection{Dilution Water}

Three sources of dilution water were used in this project. During Phase I, tests were performed with $D$. magna cultured in reconstituted distilled water (Marking and Dawson 19\%3) and well water. Columbia River water was used for Phase II tests with fish and invertebrates.

Three levels of reconstituted water were prepared (Table 3) from dilutions of the very hard formulation. Basic water chemistry parameters of well water and Columbia River water were determined bimonthly (Table 4). Assayed constituents of the dilution waters are listed in Table 5.

\subsubsection{Fish}

Four species of fish were used in toxicity tests: rainbow trout, fathead minnow, bluegill sunfish, and channel catfish (Table 6). Rainbow trout were raised at PAL facilities. The remaining three species were purchased offsite. Multiple purchases of fathead minnow and bluegill suifish were necessary because of disease.

Stucks of fish purchased offsite were routinely quarantined in well water for a period of at least 10 days prior to acclimation in Columbia River water and testing. The fish were quarantined to minimize potentiai outbreaks of disease that could result from handling stresses that occur during shipment. The lone exception to this practice was a shipment of bluegill sunfish obtained in December 1984; these fish were acclimated directly to river water when they arrived. After the quarantine period, test fish were acciimated to river water and the selected test temperature for at least 7 days before testing.

\section{Photoperiod}

Stocks of fish were maintained on a $16-\mathrm{hr}$ light to 8-hr dark photoperiod. Lighting was provided by a combination of incandescent (100 
TABLE 3. MARKING AND DAWSDN (1973) RECONSTITUTED FRESHWATER

\begin{tabular}{|c|c|c|c|c|c|c|c|c|}
\hline Name & $\mathrm{NaHCO}_{3}$ & $\begin{array}{c}\mathrm{CaSO}_{4} \cdot 2 \mathrm{H}_{2} \mathrm{O} \\
2 \mathrm{H}_{2} \mathrm{O}\end{array}$ & $\mathrm{MgSO}_{4}$ & $\mathrm{KCl}$ & $\mathrm{pH}^{\mathrm{a}}$ & $\mathrm{pH}^{\mathrm{b}}$ & $\begin{array}{l}\text { Hardness } \\
\mathrm{mg} / \mathrm{L} \mathrm{CaCO}\end{array}$ & $\begin{array}{l}\text { Alkalinfty } \\
\mathrm{mg} / \mathrm{CaCO}_{3}\end{array}$ \\
\hline Very soft & 12 & 7.5 & 7.5 & 0.5 & 6.8 & $6.4-6.8$ & $10-13$ & $10-13$ \\
\hline Soft & 48 & 30.0 & 30.0 & 2.0 & 7.4 & $7.2-7.6$ & $40-48$ & $30-35$ \\
\hline Hard & 192 & 120.0 & 120.0 & 8.0 & 8.0 & $7.6-8.0$ & $160-180$ & $110-120$ \\
\hline Very hard & 364 & 240.0 & 240.0 & 16.0 & 8.1 & $8.0-8.4$ & $280-320$ & $225-245$ \\
\hline
\end{tabular}

Approximate equilibrium pH after aeration.

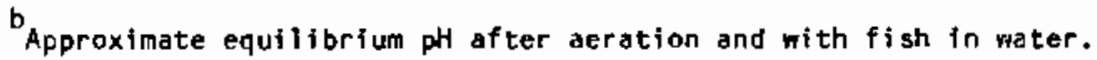

TABLE 4. BASIC WATER CHEMISTRY DF COLUMBIA RIVER WATER AND WELL WATER

\begin{tabular}{|c|c|c|c|c|c|c|c|c|}
\hline \multirow[b]{2}{*}{ Date } & \multicolumn{4}{|c|}{ Well Water } & \multicolumn{4}{|c|}{ Columbia River Water } \\
\hline & $\mathrm{pH}$ & Hardness ${ }^{a}$ & $\begin{array}{c}\text { Alkd- } \\
\text { linity }\end{array}$ & $\begin{array}{l}\text { Conduc- } \\
\text { tivity }\end{array}$ & $\mathrm{pH}$ & Hardness ${ }^{a}$ & $\begin{array}{l}\text { Alka- } \\
\text { linjty }\end{array}$ & $\begin{array}{l}\text { Conduc- } \\
\text { tivity }\end{array}$ \\
\hline $\begin{array}{l}12 / 06 / 83 \\
12 / 28 / 83 \\
02 / 10 / 84 \\
02 / 29 / 84 \\
03 / 29 / 84 \\
04 / 01 / 84 \\
05 / 11 / 84 \\
08 / 28 / 84 \\
11 / 02 / 84 \\
11 / 09 / 84 \\
01 / 4 / 85 \\
01 / 21 / 85\end{array}$ & $\begin{array}{l}7.6 \\
7.65 \\
8.0 \\
7.95 \\
7.86 \\
8.04 \\
7.96 \\
7.98 \\
7.24 \\
\text { NA } \\
\text { NA } \\
\text { NA }\end{array}$ & $\begin{array}{l}119.4 \\
116.6 \\
113.7 \\
118.8 \\
127.4 \\
127.4 \\
127.4 \\
133.3 \\
122.5 \\
\text { NA } \\
\text { NA } \\
\text { NA }\end{array}$ & $\begin{array}{l}121 \\
122 \\
110 \\
117 \\
113 \\
113 \\
115 \\
123 \\
101 \\
\text { NA } \\
\text { NA } \\
\text { NA }\end{array}$ & $\begin{array}{c}306 \\
257 \\
320 \\
325 \\
290 \\
290 \\
\text { C } \\
290 \\
277 \\
\text { NA } \\
\text { NA } \\
\text { NA }\end{array}$ & $\begin{array}{c}\text { NA } \\
7.6 \\
7.8 \\
\text { NA } \\
\text { NA } \\
\text { NA } \\
\text { NA } \\
7.98 \\
7.13 \\
7.3 \\
7.8 \\
7.7\end{array}$ & $\begin{array}{c}\text { NA } \\
65.8 \\
66.7 \\
N A \\
N A \\
N A \\
N A \\
59.8 \\
64.7 \\
63.7 \\
80.7 \\
N A\end{array}$ & $\begin{array}{c}\text { NA } \\
61.5 \\
62.0 \\
N A \\
N A \\
N A \\
N A \\
57.0 \\
46 \\
d \\
d \\
65\end{array}$ & $\begin{array}{r}\text { NA } \\
123 \\
171 \\
\text { NA } \\
\text { NA } \\
\text { NA } \\
\text { NA } \\
167 \\
123 \\
145 \\
106 \\
128\end{array}$ \\
\hline
\end{tabular}

amg/L as $\mathrm{CaCO}_{3}$ equivalent.

Tests if th this dilution mater mere not conducted at this time.

c Instrument failed.

dalues suspected to be in error due to faulty preparation of titrant. 
TABLE 5. MEASURED CONCENTRATIONS (MG/L) OF COMPONENTS IN DILUTION WATER USED IN TOXICITY TESTS

\begin{tabular}{|c|c|c|c|c|c|c|}
\hline \multirow[b]{2}{*}{ Component } & \multirow{2}{*}{$\begin{array}{c}\text { Columbia River } \\
\text { Water }\end{array}$} & \multirow{2}{*}{$\begin{array}{l}331 \text { Well } \\
\text { Water }\end{array}$} & \multicolumn{3}{|c|}{ Reconstituted Waters (a) } & \multirow{2}{*}{$\begin{array}{l}\text { Algal } \\
\text { Media }\end{array}$} \\
\hline & & & Very Hard & Hard & Soft & \\
\hline $\mathrm{F}^{-}$ & $(<0.01)$ & 0.4 & $(<0.02)$ & $(<0.02)$ & -0.01 & $(<0.01)$ \\
\hline $\mathrm{Cl}^{-}$ & 6.6 & 11 & 7.8 & 4 & 1.3 & 7.8 \\
\hline $\mathrm{NO}_{3}^{-}$ & 19.4 & 12 & $\{<0.03\}$ & $(<0.03)$ & $(<0.04)$ & 23.1 \\
\hline $\mathrm{PO}_{4}^{3} 3^{-}$ & 0.3 & 0.1 & $(<0.03)$ & $(<0.03)$ & $(<0.04)$ & $(<0.2)$ \\
\hline $8 r^{-}$ & $(<0,05)$ & $(<0.06)$ & $(<0,03)$ & $(<0.03)$ & $(<0.04)$ & $(<0.04)$ \\
\hline $\mathrm{SO}_{4}{ }^{2-}$ & 10.6 & $\sim 27$ & 270 & 175 & 50 & 12.4 \\
\hline $\mathrm{Ca}$ & 1.1 & 40 & 60 & 29 & 7.8 & 1.1 \\
\hline $\mathrm{Na}$ & 11.3 & 19 & 100 & 61 & 18.4 & 14.7 \\
\hline Mg & 4.0 & 7.7 & 32 & 25 & 7.4 & 4.6 \\
\hline$k$ & $(\infty 0.3\}$ & 5.0 & 9.3 & 2.7 & 1.1 & $(<0.3)$ \\
\hline$S i$ & 0.05 & 14 & 0.05 & 0.1 & 0.03 & 1.5 \\
\hline $\mathrm{B}$ & 0.04 & 0.03 & $\{<0.01)$ & $(<0.01)$ & $(<0.01)$ & 0.18 \\
\hline $\mathrm{Ba}$ & $(<0.01)$ & 0.03 & $(<0.01)$ & $(<0.01)$ & $\{<0.01)$ & $(<0.01)$ \\
\hline$S r$ & $(<0.002)$ & 0.16 & 0.08 & 0.01 & 0.01 & $(<0.002)$ \\
\hline $\begin{array}{l}(\mathrm{Cd}, \mathrm{Cr}, \\
\mathrm{Co}, \mathrm{Ni}, \\
\mathrm{Zn})\end{array}$ & $(<0.02)$ & $(<0.02)$ & $(<0.02)$ & $(<0.02)$ & $(<0.02)$ & $(<0.02)$ \\
\hline
\end{tabular}

Prepared by methods of Marking and Dawson (1973).

b Prepared without added phosphate (Miller et al. 1978).

watt) and fluorescent (35 watt Sylvania Supersaver II or Cool White tubes) lighting. The incandescent lights were gradually phased on and off at the beginning and end of the photoperiod.

\section{Feeding}

Fish were fed dried, conmercially prepared food (Silvercup, Murray Elevator, Murray, UT) two to three times daily. Bluegill sunfish fry obtained in September 1984, initially refused to feed. Feeding was inauced by supplementing the dried swim-up size food with live Artenia larvae, Daphnia, and periphyton communities collected onsite. The mortality rate in the group of fish two weeks preceding the test was 22 out of more than 280 individuals. Mortalities were restricted to the smallest fish in the population. The shipment of bluegill sunfish obtained in December 1984 also refused to feed after arrival. Feeding was induced with frozen brine 
TABLE 6. GENERAL INFORMATION ON FISH USED DURING PHASE II TOXICITY TESTS

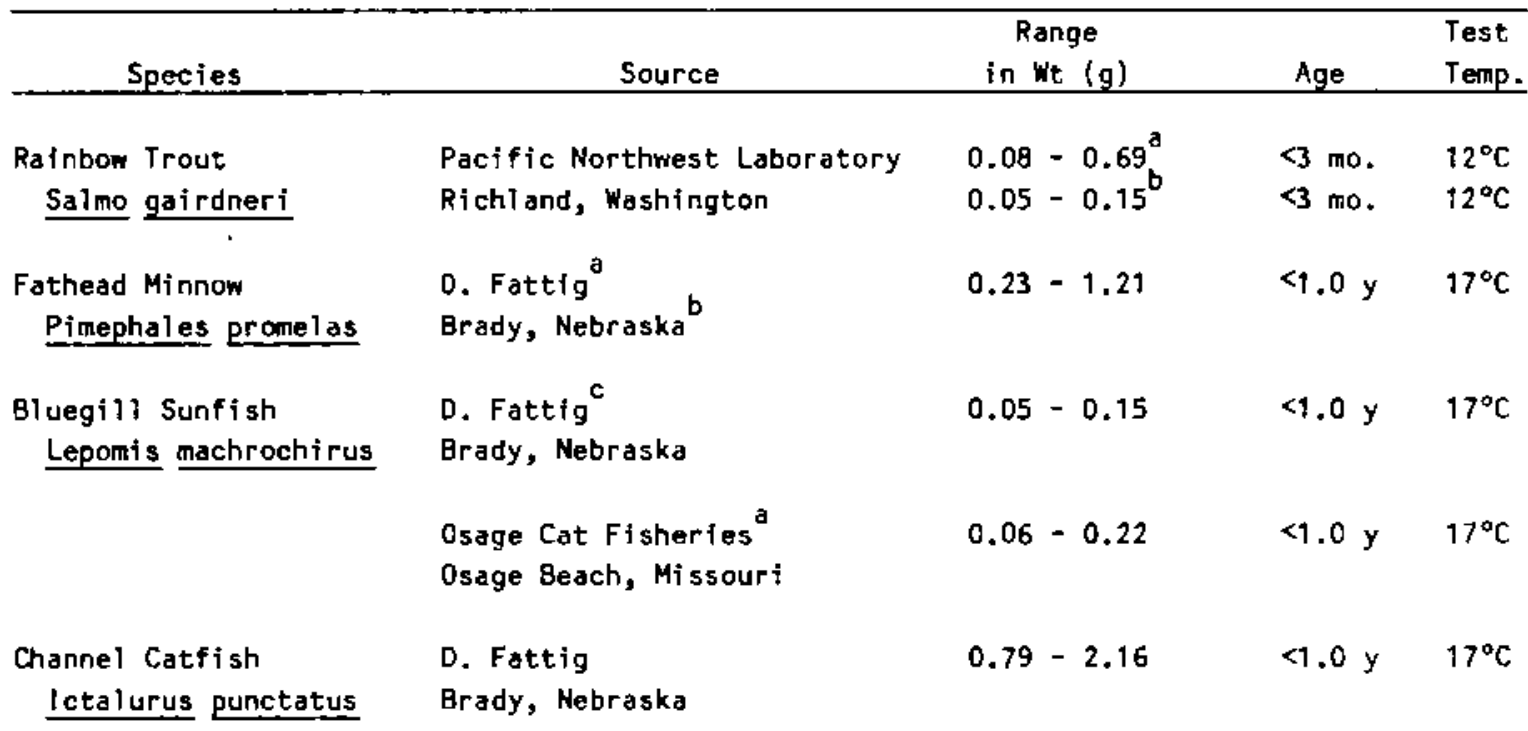

${ }^{\text {a }}$ Fish used for WP-R toxicity test.

$b_{F i s h}$ used for RP-BR toxicity test; fish brood just started feeding men tested.

${ }^{C}$ Fish used for RP-BR toxicity test.

shrimp obtained from a local pet store. No feeding problems were encountered with shipments of fathead minnow, channel catfish, or rainbow trout..

\section{Disease}

Two shipments of fish purchased for this project were destroyed because of persistent disease problems: the initial batch of fathead minnow purchased in July 1984 and a shipment of bluegill sunfish purchased in November 1984. There were no problems with disease in stocks of channel catfish or rainbow trout used in the project.

\subsubsection{Macroinvertebrates}

Four species of aquatic macroinvertebrates were used in this project (Table 7). The culture of each species of invertebrate was unique. 
TABLE 7. GENERAL INFORMATION ON MACROINVERTEBRATES USED DURING PHASE II TOXICITY TESTS

\begin{tabular}{|c|c|c|c|}
\hline Species & Source & Size & Age \\
\hline Daphnia magna & $\begin{array}{l}\text { Pacific Northwest Laboratory } \\
\text { Richland, Washington }\end{array}$ & $\begin{array}{l}\text { First } \\
\text { Instar }\end{array}$ & $12 \pm 12 \mathrm{~h}$ \\
\hline Hya1lela azteca & $\begin{array}{l}\text { Environmental Protection Agency } \\
\text { Corvallis, Oregon }\end{array}$ & $>3 \mathrm{~mm}$ & Mixed \\
\hline$\frac{\text { Paratanytarsus }}{\text { dissfmilus }}$ & $\begin{array}{l}\text { Environmental Protection Agency } \\
\text { Duluth, Minnesota }\end{array}$ & -- & 7- $11 \mathrm{day}$ \\
\hline Hexagenia sp. & $\begin{array}{l}\text { Rhodes Live Bait } \\
\text { Amherst, Wiscons in }\end{array}$ & $\begin{array}{l}0.12-0.47 \mathrm{~g} \text { we }^{\mathrm{a}} \\
0.37-0.88 \mathrm{~g} \text { wet }^{\mathrm{b}}\end{array}$ & Mixed \\
\hline
\end{tabular}

$\mathrm{a}_{\text {Tested in November and December } 1985 .}$

Tested in January 1985.

\section{Daphnia magna}

Daphnia magna were cultured by static renewal. The cultures were fed the green alga Selenastrum capricornutum (see Section 2.4.3) and suspensions of blended trout chow. The algae were fed daily at a final concentration of $10^{\circ} \mathrm{cells} / \mathrm{L}$ and the trout chow was administered at a leve] of $5 \mathrm{mg} / \mathrm{L}$ after water exchanges. Water exchanges were performed three times per week. The feeding of trout chow was curtailed when it appeared that feeding may have been related to culture problems with a pathoiogical infestation of fungus. Feeding of trout chow was resumed after the problem was alleviated.

Cultures were routinely maintained on well water or river water for this project. Special tests in Phase I of the project required acclimation of $D$. magna stocks to three levels of reconstituted water (Table 3 ). CuTture water was changed and cultures were thinned three times a week. Cultures were grown at $20+1^{\circ} \mathrm{C}$ on a 16:8 hr 1ight:dark cycle.

First instars were collected for testing by isolating brood bearing females in a 500-mL beaker one day prior to testing. Offspring born overnight were used for testing on the following day.

Hexagenia

Mayfly larvae were maintained under flow-through conditions $(\sim 1.0$ $\mathrm{L} / \mathrm{min} ;$ ) in well water at $11.5^{\circ} \mathrm{C}$ to retard maturation and emergence. 
Cuttures were acclimated to river water $\left(\sim 100 \mathrm{~mL} / \mathrm{min} ; 17^{\circ} \pm 1^{\circ} \mathrm{C}\right)$ at least five days prior to testing. The photoperiod was 16:8 light:dark. The holding aquaria contained 4 to $5 \mathrm{~cm}$ of mud collected from the Columbia River. The larvae fed on naturally occurring detritus in the mud and periodic additions of rabbit pellets, dried oak leaves and suspensions of Cerophyl, a dried preparation of rye cereal leaves.

Organisms were collected by gently resuspending the mud substrate and transferring the larvae by hand to a bucket of river water. Exposures were initiated by transferring larvae in groups of 10 from the bucket to the aquaria with a small fish net. Organisms that appeared injured or swam irregularly were discarded.

\section{Paratanytarsus dissimilus}

Midge larvae were grown under static conditions in $16 \mathrm{~L}$ battery jars and 190 by $100 \mathrm{~mm}$ crystalizing dishes. Egg cases were collected by isolating two to four newly-emerged females in scintillation vials with $2 \mathrm{~mL}$ of river water. After two days, the egg cases were transferred to the larger culturing vessels. Fifty milliliters of a Cerophyl suspension that had been blended and strafned through plankton netting was added to each container. The suspension was prepared by blending $20 \mathrm{~mL}$ dry volume Cerophyl in $100 \mathrm{~mL}$ of distilled water for $3 \mathrm{~min}$. The suspension was then passed through piankton netting before the solution was added to the culturing chamber. Cultures were maintained at $20^{\circ}$ to $22^{\circ} \mathrm{C}$ on a $16: 8 \mathrm{hr}$ light:dark photoperiod. Cultures raised for test purposes were raised in the crystalizing dishes. These cultures were started 10 to 13 days prior to testing to ensure that larvae would be 7 to 11 days old at testing.

Organisms were collected by prodding the organism's case with a pipet and capturing the Tarvae as it swam out the other end. Larvae were collected by this method and pooled into a $250-\mathrm{mL}$ beaker for allocation to exposure beakers on the day of a test. The larvae were transferred $w^{\prime}$ th a 0.6-mm diameter pipet.

\section{Hyal lela azteca}

Cultures of $\mathrm{H}$. azteca were grown at $17^{\circ} \pm 2^{\circ} \mathrm{C}$ on a $16: 8 \mathrm{hr}$ i ight:dark photoperiod in a $\bar{a} 30-\mathrm{L}$ glass aquarium receiving $\sim 100 \mathrm{~mL} / \mathrm{min}$ of $\mathrm{filtered}$ $(75 \mu \mathrm{m})$ river water. Dried oak leaves were used as a substrate and were supplemented with commercially available pelleted rabbit food two to three times weekly. Additional dried leaves were added as needed. Tests were performed with randomly allocated juveniles $(\sim 2 \mathrm{~mm})$ and adults. Organisms were collected with a $0.6-\mathrm{mm}$ pipet on the day of testing and pooled into a 600 - to $1000-\mathrm{mL}$ beaker for allocation to exposure beakers.

\footnotetext{
Trademarks of the Agri-Tech, Inc. Kansas City, Missouri
} 


\subsubsection{Algae}

The unicellular green alga, Selenastrum capricornutum, was grown in two different media for two distinct purposes. Bold basaT media (Nichols and Bold 1965) adjusted to a $\mathrm{pH}$ of 6.6 was used to culture large quantities of algae for feeding $D$ magna. This media was supplemented with vitamins (Goulden et al. 1982, see Appendix B). Algae were grown at $23^{\circ}$ to $26^{\circ} \mathrm{C}$ with illumination provided by "cool-white" fluorescent lighting at a flux of 60 Einstein's $\mathrm{m}^{-2} \mathrm{~s}^{-1}$ (4304 lumens $\left.\mathrm{m}^{-2}\right)$. Charcoal filtered aeration was provided to enhance growth.

Algae were grown in EPA media (Miller, Greene and Shiroyama 1978) for toxicity testing purposes. The media was adjusted to a pH of $7.5 \pm 0.1$. Algal cultures were grown for at least $96 \mathrm{hr}$ on this media prior to toxicity testing. Basic growth conditions were the same as described for Daphnia food with daily shaking in lieu of aeration. Algal stimulation tests required that phosphorus be elininated from the media. Separate batches of media were prepared without $\mathrm{K}_{2} \mathrm{HPO}_{4}$ for $\mathrm{RP}-\mathrm{BR}$ and $\mathrm{HP}-\mathrm{F}$ algal growth stimulation tests. All algal media were filtered $(0.45 \mathrm{\mu m})$ under positive pressure ( 5 to 10 psi) to lower background levels of particles for the soutter counter and autoclaved (15 psi and $121^{\circ} \mathrm{C}$ ) before use.

\subsection{TOXICITY TEST METHODS}

This section discusses the methods used to generate stock solutions containing fog oil and phosphorus-based obscurants. Methods used to test algae, invertebrates and fish are also described.

\subsubsection{Preparation of Exposure Solutions}

This section describes the methods used to prepare exposure solutions with obsclirants. Combustion of phosphorus-based obscurants and vaporization of fog oil were discussed in Section 2.2.

Red Phosphorus-Butyl Rubber and White Phosphorus-Felt

The methods for burning RP-BR and WP-F materials and collecting their combustion products are discussed in Section 2.2. Deperiding on the amount of stock solution required for testing, two systems could be used to generate stcck solutions: four 54-L (12-gal) plastic carboys or a 760-L (200-gal) plastic carboy.

For tests with algae and macrojnvertebrates (except Hexagenia), four 54-gat plastic carboys containing $1.0 \mathrm{~L}$ of dilution water were dosed with smoke. After a 1.5-hr settling period, the sides were rinsed by rolliric the carboys onto their sides and inverting them. The contents of each carboy were used to prepare exposure solutions for toxicity testing.

For tests with fish and Hexagenia, the larger 760-L Fusion carboys were filled with $5 \mathrm{~L}$ of dilution water for dosing. After a 4-hr settling 
period, the carboy was vented under building vacuum and the sides were rinsed with an additional $15 \mathrm{~L}$ of diluent. The stock solution was drained by a PVC ball valve located in the corner of the carboy.

\section{$\underline{\text { Fog } 0 i 1}$}

Exposure solutions of bulk fog oil and vaporized fog oil were prepared using slow-mix methods comparable to methods used for testing other complex organic liquids (Dauble et a1. 1983). The mixing methodology was designed to provide an exposure solution that was not overly burdened with excessive amounts of insoluble fog oil. Mixing energy was limited to levels that would reasonably simulate mixing energies expected to occur in most natural aquatic habitats. The mixing energy was increased in some tests at the end of Phase II.

A stock solution was prepared by slowly mixing the fog oil for $4 \mathrm{hr}$ at room temperature $\left(23^{\circ} \pm 2^{\circ} \mathrm{C}\right)$. A Heidolph variable-speed stirrer was fitted with a Nalgene three-blade propeller for mixing. The propeller blades were positioned $2.5 \mathrm{~cm}$ below the surface of the water. Mixing was started after the fog $0 i 1$ had been added to the system. Two different systems were used. For algal toxicity tests, $100 \mathrm{~mL}$ of fog oil was added to $10-\mathrm{L}$ volumes of sterile media and mixed at $174 \pm 10 \% \mathrm{rpm}$ in 5 -gat Pyrex carboys for $4 \mathrm{hr}$. The mix was allowed to settle for $1 \mathrm{hr}$. The stock solution was obtained by siphoning the water out of the carboy while taking care not to entrain any oil. This setup was also used with well water and river water to prepare stock solutions for testing smaller invertebrates.

A large system was needed to generate sufficient stock solution to expose fish and Hexagenia Tarvae. A 12 -gal Pyrex ${ }^{\otimes}$ carboy was filled with $30 \mathrm{~L}$ of diluent and $300 \mathrm{~mL}$ of fog 011 . The solution was mixed for $4 \mathrm{hr}$ and allowed to separate for $1 \mathrm{hr}$. Concentrations of oil comparable to the 10-L slow mix solution could be achieved by increasing the rpm to $240 \pm 10 \%$.

\section{Photolyzed Fog 0 il Tests}

Two series of tests were performed with photolyzed fog oils. The first series of tests used fog oil that had been photolyzed for $24 \mathrm{hr}$; the second series used $0 i 1$ that had been photolyzed for 7 days. In each series, four types of Batch 3 fog ofl were tested: bulk, photolyzed bulk, vaporized (FO-4), and photolyzed-vaporized fog oil (see Table 2). Each was used to prepare a stock solution for preliminary chemical characterization and toxicity testing with $\underline{H}$. azteca.

The generation of stock solutions with photolyzed fog oil differed considerabty from the methods used for bulk and vaporized fog oil because of the small amounts ( $4 \mathrm{~mL}$ ) of photolyzed fog oil available. Stock solutions were prepared in two different ways. In the initial tests with 24-hr

\footnotetext{
Trademark of Poly Science, Inc.
}

-Trademark of Corning Giass Works 
photolyzed fog $0 i 1$, a magnetic stirrer was set at 400 to $600 \mathrm{rpm}$ with a 3.75-cm Teflon stir bar for $2 \mathrm{hr}$. Approximately 3.2 to $4.0 \mathrm{~mL}$ of photolyzed fog oil was mixed with $400 \mathrm{~mL}$ of river water and allowed to settle for $1 \mathrm{hr}$ after mixing. The resulting stock solutions were turbid, indicating that the oil-water dispersion had not completely separated into discrete 011 and water fractions. These solutions were used to prepare two exposure solutions, $100 \%$ and $20 \%$, for screening toxicity tests with $\underline{H}$. azteca.

The method for generating stock solutions was further modified to produce much less mixing energy than was present with the magnetic stirrer method. The magnetic stirrer method aiso made it difficult to control rpm, thereby introducing more variability in the mixes. To alleviate this problem, we used laboratory stirring motors and three-blade propeller apparatuses to mix the solutions. These were the same devices used for the standard slow mixes in Phase II of the project, except that the volumes used in the mix were greatly reduced. The mixing energy was set at $174 \pm 10 \% \mathrm{rpm}$. Two and one half milliliters of 017 was added to $900 \mathrm{~mL}$ of river water and mixed for $2 \mathrm{hr}$. The mixture was allowed to separate for 1 $\mathrm{hr}$ before the 0il-water dispersion was siphoned off to prepare exposure solutions. Five dilutions of the photolyzed bulk and photolyzed-vaporized fog oil stock solutions were prepared for testing. Two exposure solutions ( $20 \%$ and $100 \%$ ) were prepared with the bulk and the vaporized Batch 3 fog 0i1. After the initial 48-hr test, the $100 \%$ exposure solutions for the photolyzed bulk and vaporized fog oil were retested by siphoning off and combining the water from each beaker. Care was taken not to transfer any of the residues floating on the surface into clean exposure beakers. Hyallela azteca were exposed to the solutions for $48 \mathrm{hr}$. The unphotolyzed 100\% solutions of bulk and vaporized fog oil stock solutions were not tested because no toxicity was apparent in the initial test.

\subsubsection{Fish}

Static conditions were used for all 96-hr acute toxicity tests. The methods used were based on standard practices developed by the American Society for Testing and Materials (ASTM 1980). The standard test conditions were modified in tests where fish were too large for the standard carboy or when not enough stock solution was available for setting up the test (Appendix $C$ ). These modifications involved reducing the number of fish per aquarium and/or reducing the number of test concentrations.

Screening tests with fog oil were conducted with fathead minnow at $100 \%$ and $10 \%$ stock solutions prepared under standard slow mix conditions (see Section 2.6.1). The remainfing species of fish were not tested with fog oil because the three batches showed no apparent toxicity.

\footnotetext{
Trademark of E. I. duPont de Nemours \& Co.
} 
Temperature, dissolved oxygen, and mortality were monitored daily. Ammonia concentrations were measured at the end of the tests (Appendix C). Measurements were taken more often in tests where the biomass of fish per aquarium approached the load limit of $0.8 \mathrm{~g} / \mathrm{L}$. Hydrogen ion concentrations were monitored daily when WP-F or RP-BR was tested. Concentrations of toxicants were measured at the start of all toxicity tests and at the end of tests in aquaria containing live fish in 96-hr tests with phosphorusbased obscurants. Phase I tests have shown that total $P$ concentrations were stable for periods to $96 \mathrm{hr}$. Routine daily monitoring of an aquarium was terminated after all fish in that aquarfum had died.

\subsubsection{Macroinvertebrates}

The methods used for acute tests of macroinvertebrates are based on standard methods prepared by ASTM (ASTM 1980). Because the biology of these macroinvertebrates is unique, the handiing and testing of these organisms are discussed individually. Generally, tests with fog oil were performed in glass containers, and tests with phosphorus-based obscurants were conducted in plastic beakers.

\section{Daphnia magna}

Daphnia magna were tested in Phases I and II of this project. First instar daphnids $(12 \pm 12 \mathrm{hr})$ were used to initiate all tests. Phase I tests used well water and three hardness ievels of reconstituted water: very hard, hard, and soft (Marking and Dawson 1973). The duration of these tests was extended from 48 to $96 \mathrm{hr}$ because a bimodal toxic response had been noted earlier in the project and was considered worthy of continued investigation. During Phase II, al] testing was conducted in Columbia River water for a period of $48 \mathrm{hr}$. These five types of dilution water provided a broad spectrum of water quality conditions that allowed us to evaluate the acidification potential of the phosphorus-based obscurants.

Tests with $D$. magna were also performed during Phase $I$ to ascertain the effect of aging on the toxicity and chemistry of WP-F and RB-BR combustion products. In these tests, dilutions of well water that had been dosed with smoke were prepared and allowed to age for up to 28 days. During this time, $96-\mathrm{hr}$ tests were started at elapsed times of 0 days, 5 days, and $26(R P-B R)$ or 28 (WP-F) days. Mortality temperature, and $p H$ were monitored during the $96-\mathrm{hr}$ testing period. During each test at 5 and 26 (or 28 ) days, a fresh $40 \%$ solution was prepared from the original stock solution. The fresh $40 \%$ solution monitored potential changes in the toxicity of the more concentrated stock solution.

In conjunction with the Phase I tests, chemical analyses were performed to evaluate the speciation and rates of hydrolys is of WP-F and RP-BR combustion products in water (see Section 3.2). 


\section{Hexagenia}

Mayfly Tarvae were tested in duplicate aquaria containing $10 \mathrm{~L}$ of exposure solution. The weight of these orgarisms ranged from 0.12 to $0.47 \mathrm{~g}$ and the mean weights for selected test groups ranged from 0.25 to $0.29 \mathrm{~g}$. Test organisms were collected from holding aquaria by resuspending the mud substrate and gently transferring the organisms by hand to a plastic pail. Test organisms were added to the exposure aquaria in groups of 10 in the order of random assignment of treatnents. Observations for mortality, temperature, $\mathrm{pH}$ (phosphorus-based obscurants only), and dissolved oxygen were made daily for $48 \mathrm{hr}$. Test organisms that had been maintained on well water were acclimated to river water at least 5 days before testing. The organisms were tested at two temperatures. The screening toxicity tests with the three batches of fog $0 i 1$ were conducted at $20 \pm 1^{\circ} \mathrm{C}$. The remaining tests were conducted at $17^{\circ} \pm 1^{\circ} \mathrm{C}$ to reduce the potential for energence. The photoperiod was 16:8 light to dark.

Hexagenia was the test organisms used to screen the toxicity of fog 0 it in Phase II of the study. Stock solutions were prepared in $30-\mathrm{L}$ quantities, and two exposure solutions (100\% and $20 \%)$ were prepared in duplicate for testing.

\section{Paratanytarsus dissimilus}

Midge fly larvae were tested in 100-mL beakers containing $90 \mathrm{~mL}$ of exposure solution. Four beakers were assigned to each treatment, and the tests lasted for $48 \mathrm{hr}$. Twenty organisms were exposed at each concentration tested. Reagent grade sea sand $\left(0.3 \mathrm{~g}\right.$ per beaker) and Cerophy ${ }^{\circ}$ ( $5 \mathrm{mg}$ per beaker) were added to each beaker as substrate to prevent cannibalism. Test temperature was $20^{\circ} \pm 2^{\circ} \mathrm{C}$ and the photoperiod was 16:8 light to dark. Observations were made only at $48 \mathrm{hr}$ because the organisms had to be individually accounted for by removing them from their tubes.

\section{Hyallela azteca}

Methods for testing amphipods were the same as those for testing P. dissimulus, except that observations were made at 24 and $48 \mathrm{hr}$ and a substrate was not placed in the exposure beakers.

\subsubsection{Algae}

The methods used to assess the toxicity of the obscurants were based on a draft standard practice under preparation by ASTM for conducting acute toxicity tests with unicellular algae. The basic procedure involves the preparation of at least five exposure solutions and a control (six treatnents). Stock solutions were prepared with EPA media filtered at 0.22 um (Miller, Greene and Shiroyama 1978). Stock solutions prepared with 
fog $0 i 1$ were mixed in 10- $L$ amounts with a standard slow mix (174 $\pm 10 \%$ rpm). White phosphorous felt and RP-BR smokes were vented into 54-L Nalgene carboys (see Section 2.6.1) to dose algal media. The alga S. capricornutum was inoculated at a final concentration of $10,000 \mathrm{ce} 11 \mathrm{~s} / \mathrm{mL}$ into 125-mL flasks (three flasks per treatment) containing $25 \mathrm{~mL}$ of exposure solution. The Batch 2 fog oil test inadvertently received an inoculum, resulting in a concentration of $2 \times 10^{5} \mathrm{cel1} / \mathrm{s} / \mathrm{mL}$. In some of the later tests, the inoculum was increased to $2 \times 10^{4}$ cells $/ \mathrm{mL}$ to enhance biomass estimates at the end of the test and reduce variability. The flasks were placed in a randomized grid system prior to inoculation.

Tests were conducted at $24^{\circ} \pm 2^{\circ} \mathrm{C}$ under continuous lighting of $60 \mu$ Einstein's $\mathrm{m}^{-2} \mathrm{~s}^{-1}$ (4304 lumens $\mathrm{m}^{-2}$ ). Illumination ranged $\pm 10 \%$ over the exposure grid. Algal biomass measurements (cell counts) were determined daily over the 96-hr duration of the test by use of a Model $\mathrm{ZN}$ Coulter counter. At $96 \mathrm{hr}$, a sample from each flask was removed for chlorophyll analysis. In some tests, chlorophyll measurements were also taken at $48 \mathrm{hr}$. The analys is involved the extraction of chlorophyll with $90 \%$ acetone after rupturing the algal cells by grinding an aliquot collected on a glass filter pad (Lorenzen 1966). The chlorophyll extracts were analyzed for fluorescence with a Turner Model 111 fluorometer equipped with a 5-60 blue primary filter and a 5-64 red secundary filter. The instrument was calibrated against a Turner Model 112 at the College of Ocean and Fisheries Science, University of Washington, to determine the appropriate calibration constants for the windcw selection.

Because a major combustion product of WP-F and RP-BR is orthophosphate ( $\mathrm{RO}_{4}{ }^{-}$) the algal toxicity test procedure was modified to test for the algal stimulation potential of these obscurants. A separate batch of EPA media deficient in $\mathrm{PO}_{4}^{3}$ - was prepared for dosing with smoke. After dosing, the stock solution was separated into two portions. One portion was neutralized with sodium hydroxide to the original pH of the media and the other was left acidic. Dilutions were prepared with the acidic smokedosed media and the $\mathrm{PO}_{4}^{3}$--deficient media, yielding $\mathrm{pH}$ values of $5.0,5.5$, 6.0 , and 6.6 , and a control. Identical dilutions were prepared with the neutralized portion in order to separate the effects of $\mathrm{pH}$ from excess $\mathrm{PO}_{3}^{3}$. Because of the low buffering capacity of the EPA media (16 $\mathrm{ng} / \mathrm{L} \mathrm{CaCO}$ equiv.), the actual concentrations of phosphorus combustion products were low. Exposure solutions were monitored for $\mathrm{PO}_{4}^{-}$and $\mathrm{PO}_{3}^{2}$ by ion chromatography and the total-P levels of the stock solution were determined by ICP.

\subsection{STATISTICAL METHODS}

This section describes methods used to analyze toxicity data and algal growth response data. 


\subsubsection{Toxicity Data}

Acute toxicity tests with fish and macroinvertebrates were analyzed using the trimked Speaman-Karber (SPEAR Program) method (Hamilton, Russo and Thurston 1977). Median lethal concentration (LC50) values and 95\% confidence intervals were reported for $\mathrm{pH}$ and total $\mathrm{P}$. The $\mathrm{pH}$ values were not transformed to molar concentrations because of the wide range of pH values tested. The wide range (five orders of magnitude) of hydrogen ion concentrations could not be handled with the existing program. The $L C_{50}$ values and confidence intervais for $\mathrm{pH}$ agree well with the total $\mathrm{P}$ values, and are considered close estimates of the true values.

Mortality of fish in replicate aquaria were analyzed individually when differences in the $\mathrm{pH}$ or total $P$ concentrations within a treatment were noteworthy (i.e., greater than $40 \%$ difference between aquaria). With the exception of tests with D. magna, none of the tests with fog oil yielded a mortality rate greater than $35 \%$ at the end of the test. In tests with D. magna, the phenomenon of "floaters" ( $p .96)$ compromised our interpretaticn of the data. Consequently, LC50 values were not determined for any of tre toxicity tests with fog oil.

\section{7.c Algal Toxicity and Growth Stimulation Tests}

The growth response of 5 . capricornutum was measured daily to evaluate algal toxicity. Sampling included daily cell counts and chlorophyll analysis at the end of the tests. On isolated occasions, chlorophyl t samples were taker at $48 \mathrm{hr}$. Statistical analyses were performed on cell count data only. Mean chlorophyll values were not statistically analyzed because the oata base for cell counts spanned the entire test and were, therefore, the more rigorous data set.

Differences between treatments (toxicant concentration) were tested with a repeated measures analysis of variance (ANOVA) where cell counts taken over time constituted the repeated measures. The BMDP VAX 1983 version (Dixon et al. 1983) was used to analyze all cell count data. When either the treatment of main effects interaction were significant, additional tests were performed to determine significant differences between treatment means. Differences between treatment means (simple effects) were tested separately at each sample time with an $F$ test (Winer 1971). If the $F$ test was significant for any sample time, individual treatment means for that time were compared using a modified least significant differences (LSD) procedure for multiple pairwise comparisons (Winer 197I). Scheffe's critical value for multiple pairwise comparisons was used for individual mean contrasts in all tests.

Analyses were also performed on individual treatment means without Scheffe's critical value. In these tests, the error rate was unknown and was assumed to be greater than 0.05 . These tests are referred to as less conservative tests. Whereas these tests showed a greater number of 
significant comparisons between treatment means, they should be viewed with caution because of the uncertainties in the error rate. At most, we are certain that tests which showed no significance were indeed not significant. These additional tests were conducted to gain a better understanding of trends in the data.

Analysis of the growth stimulation tests with phosphorus-based obscurants paralleled the analys is of the acute toxicity tests. A repeated measures analysis of variance was used with two treatment factors, total $P$ and $\mathrm{pH}$ (neutralized and non-neutralized), and one repeated measure (cell counts). Simple effects tests were performed and individual cell means were contrasted at each sample period. Scheffe's critical value was used to protect against underestimating the error rate for multiple comparisons. 


\subsection{RESULTS}

This chapter describes aerosol generation, chemistry and toxicity of RP-BR smoke, WP-F smoke, and SGF No. 2 fog oil generated during the project. The rationale for the selection of settling as the method of choice for generating stock solutions is presented for all three obscurants. Aerosol concentrations of P-based obscurants are reported and compared to the resulting concentrations of total $P$ in stock solutions.

The chemistry of RP-BR and WP-F smoke introduced into water is assessed. The relationship between composition of the combustion products in water, acidification of the dilution water, and the resulting aquatic toxicity is evaluated.

Bulk and vaporized fog $0 i l$, and OWMs prepared from them, are characterized, and the selection of methods used to monitor these materials in water are described. The production of oxidation products induced by photolysis of bulk and vaporized fog oil is discussed. The toxicity of the bulk fog oil and the influence of vaporization and photolysis on toxicity is evaluated.

\subsection{AEROSOL GENERATION}

Various methods were evaluated for dosing water with phosphorus-based obscurants and SGF No. 2 fog oi1. Phosphorus-based obscurants were burned in a flow through system that vented the smoke into carboys where it could settle into dilution water. Bulk fog oil was vaporized and collected on stainless steel trays in a laboratory animal exposure chamber. Stock solutions for toxicity testing were prepared by mixing vaporized and condensed fog oil with dilution water.

\subsubsection{Red Phosphorus-Butyl Rubber and White Phosphorus-Felt}

The concentrations of smoke generated for dosing water varied by as much as a factor of four depending on the requirements of the specific test.. Total phosphorus concentrations in the stock solutions were used to estimate the settling and recovery efficiency of the carboy dosing system. The systen for dosing water with four 54-L carboys yielded a consistent relationship between the monitored smoke concentration and the total $P$ levels measured in the stock solution. The expected concentration of total $P$ in the stock soiution was estimated by adjusting the mean smoke concentration for the volume of the carboys and the percentage of $P$ in the smoke derived from desiccated samples. It was assumed that the percentage of $P$ in the smoke was $30 \%$ (Van Voris et al. 1985).

For RP-BR burns in which four 54-L containers were dosed, the ratios of total $P(\mathrm{mg} / L)$ in the stock solutions to the expected concentration of total $P$ ranged from 0.34 to 0.58 (Table 8 ). In comparison, the ratios for WP-F 
TABLE 8. SUMMARY OF RP-BR SMOKE GENERATION AND THE RELATIONSHIP BETWEEN SMOKE CONCENTRATION ANO PHOSPHORIS CONTENT IN STOCK SOLUTIONS

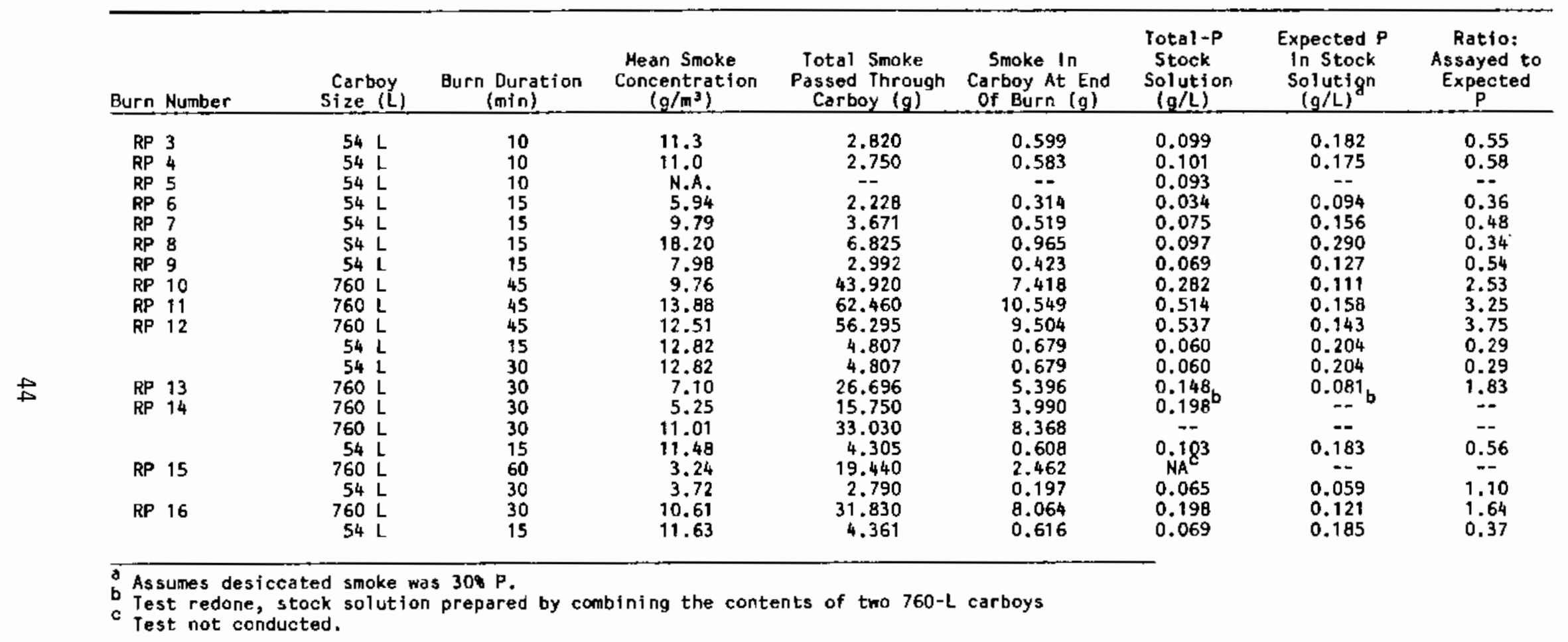


ranged from 0.38 to 1.24 (Table 9) and were generally higher than those observed for RP-BR. The smaller percentage and more variable distribution of $P$ in WP-F may account for the wider variation in the range of ratios for WP-F. A ratio of 1.00 indicates that all smoke in the $54-\mathrm{L}$ carboys settled and was dissolved when the sides were rinsed. These ratios were

consistently $<1$ in al1 burns of 17 min or less except for WP-8. Burns WP-2 and WP-3 were excluded because two rather than four carboys were dosed and the measured flow rates per carboy were $41 \mathrm{~L} / \mathrm{min}$ instead of $25 \mathrm{~L} / \mathrm{min}$.

Toxicity tests with fish required larger volumes of stock solution than were required for tests with invertebrates. The larger volumes of solution generally contained greater quantities of combustion products. The relatively consistent relationship between expected and observed total $P$ concentrations observed in the 54-L system does not hold up for stock solutions generated in the 760-L Fusion carboys. The latter ratios ranged from 1.73 to 2.34 for WP-F (Table 9) and from 1.64 to 3.75 for RP-BR burns (Table 8). Ratios in excess of 1.0 indicate that more $P$ was found in the stock solutions than could be accounted for in smoke left in the carboy when the burn was terminated. These differences may in part be explained by increased amounts of combustion products adhering to the sides of the carboys as the smoke concentrations were brought to equilibrium. Burns in the Fusion carboys lasted $30 \mathrm{~min}$ and longer to allow the smoke concentration in the larger carboys to reach equilibrium. The Fusion carboys had a greater inside surface area $\left(53,475 \mathrm{~cm}^{2}\right.$ compared to $7,428 \mathrm{~cm}^{2}$ in the $54 \mathrm{~L}$ carboys) to which the smoke could adhere. Either of these factors could account for the higher than predicted concentrations of total $P$ in the stock solutions.

Data from the 54-L carboy burns was used to establish the relationship between the amount of smoke necessary to create toxic conditions as indicated by total $\mathrm{P}$ and $\mathrm{pH}$. Based on the mean of seven RP-BR burns, the ratio of total $P$ in the stock solution to the estimated mass of smoke in the carboys at the time the burn was at equilibrium was $0.14 \pm 0.03$. The ratio for WP-F, also based on seven burns, was $0.23 \pm 0.08$. Comparison of expected to measured concentrations does not account for retention of smoke during the burn. Retained smoke would increase the ratio. It is possible that turbulence within the carbovs can minimize the retention of smoke on the sides of the carboys during the burns. With a flow rate of $25 \mathrm{~L} / \mathrm{min}$, the volume of the carboys turns over every 2 minutes. In comparison, the turnover rate in the $760-\mathrm{L}$ Fusion carboys is 7.6 minutes. Because of the large imbalance of assayed $P$ to expected $P$ in the stock solutions, caution should be used when attempting to extrapolate this relationship to field situations.

\section{1 .2 SGF No. 2 Fog $0 i 1$}

Settling of fog oit after repeated burns (FO-1) was selected during Phase I as the best method of generating and collecting vaporized fog oil for Phase II tests (Table 10). The trial vaporization with the MYSTAIRE 
TABLE 9. SUMMARY OF WP-F SMOKE GENERATIONS AND THE RELATIONSHIP BETWEEN SMOKE CONCENTRATION AND PHOSPHORUS CONTENT IN STOCK SOLUTIONS

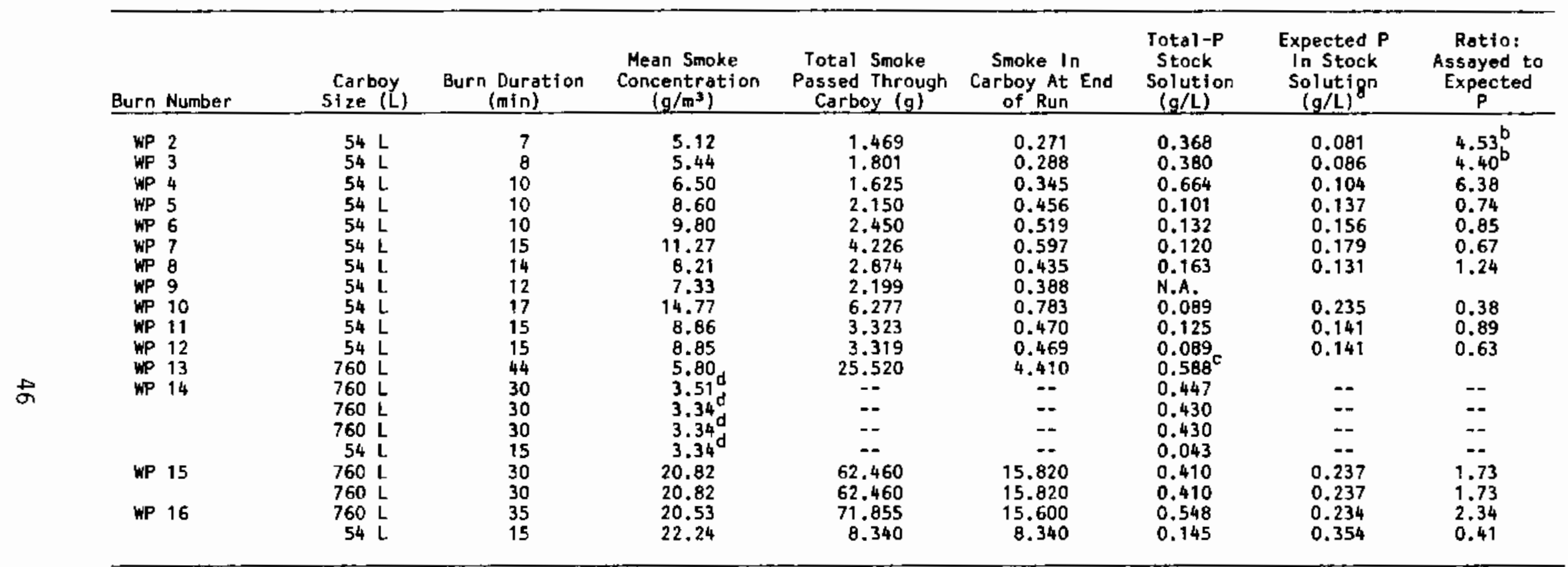

Assumes dessicated smoke was $30 \% \mathrm{P}$.

Flow rate per carboy was $41 \mathrm{~L} / \mathrm{mtn}$ all other $54-\mathrm{L}$ carboy fiow rates were $25 \mathrm{~L} / \mathrm{min}$.

Stock solution contaminated with tube condensate.

Filtering device was faulty, values were probably 10 . 
TABLE 10. SUMMARY OF FOG OIL VAPOR GENERATIONS

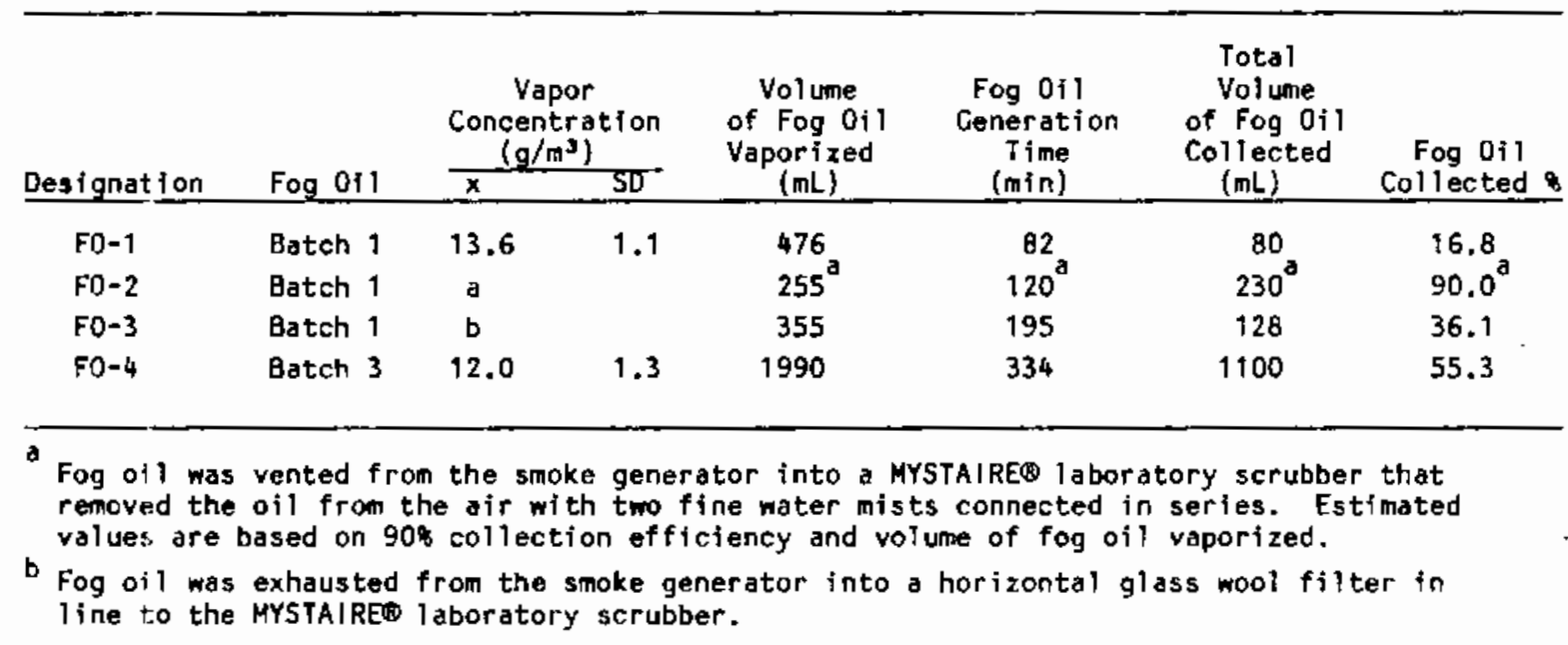

scrubber (FO-2) produced a totally emulsified solution that failed tc separate into a discrete oil-water dispersion suitable for toxicity testing. Collection of vaporized fog $0 i l$ by filtration of the aerosol in glass wocl (FO-3) was cumbersome, labor intensive, and had a low yield per unit effort. Moreover, adsorption of oxidized organics to the glass wool could alter the composition and resulting toxicity of the vaporized fog oit. Bubbling vaporized fog $0 i 1$ through water was assumed to be as inefficient as was observed with RP-BR burns (see Section 3.1.1). The negative aspects of aqueous scrubbing and glass wool filtration, coupled with the fact that settling represented the most realistic mode of vapor collection, dictated the selection of the settling method.

Vapor generations F0-1, F0-2, and F0-3 were conducted with Batch 1 fog oil. This was the oldest, darkest (possibly more oxidized) batch of oil. Batch 3 fog oil was used for $\mathrm{FO}-4$ because there was no apparent difference in toxicity among the three batches of fog $0 i 1$, the drum had not been operied prior to its arrival at PNL, and it was the most recently manufactured batch of $0 i 1$.

In the first settling test (F0-1), fog oil vapor was generated with $100 \%$ nitrogen. In subsequent generations, the vapor was generated with a mixture of air (4\%) and nitrogen, yielding an air stream of $\sim 0.8 \% 02$. This percentage of $\mathrm{O}_{2}$ represents the theoretical concentration of oxygen present in the exhaust of a finely tuned gasoline engine. Fog oil vaporized in the presence of $-1.2 \% \mathrm{O}_{2}$ was distinctly darker than fog $0 i 1$ generated in $100 \% \mathrm{~N}_{2}$ and contained a higher concentration of free radicais than the original parent oil (see Section 3.3.3). 


\subsection{PHOSPHORUS-BASED OBSCURANTS}

Combustion of RP-BR and WP-F materials produces a smoke containing many oxidation products of $P$. Introduction of these materials into water results in a lowering of $\mathrm{pH}$ and the addition of linear and cyclic oxyphosphoric acids. This section discusses the chemistry and resulting toxicity of these combustion products in water. Acute toxicity was related to decreases of $\mathrm{pH}$ caused by hydrolysis of the phosphorus combustion products.

\subsubsection{Chemistry}

This section reviews the procedural development of methods used to characterize phosphorus combustion products in water and to identify the composition and speciation of combustion products in water. This section a] so summarizes the basic characteristics of stock and exposure solutions used for aquatic toxicity testing.

\section{Preliminary Studies}

Initial tests to determine the best method of dosing water with phosphorus smoke showed that allowing smoke to settle under static conditions over water appeared to be more realistic of field conditions than allowing it to bubble through the water. Static settling resulted in a lower ratio of phosphate to total $P$ and also a lower ratio of phosphite to phosphate. Static and bubbling procedures and the resuiting changes in water composition are compared in Figures 6 and 7 . The loss of buffering capacity (decrease in $\mathrm{HCO}_{3}^{-}$) results from titration by the addition of phosphoric acids. Though phosphate concentrations increased with time, the change was not dramatic. Rinsing of the container walls following static settling greatly increased the level of total $P$ in the solutions (Figure 6). Concentrations of $\mathrm{P}_{4}^{3-}$ were re-examined after prolonged aging. After 70 days, phosphate accounted for only one third of the total $P$ in the bubhled water test; between 150 and 180 days the phosphate Tevel remained at roughly $50 \%$. Based on these results, plus the fact that settling better typifies actual field conditions, the settling mode was selected for dosing water.

Combustion products of P.P-BR and WP-F were similar. Precipitated material formed when smoke-dosed waters were diluted or neutralized. The critical pH level appeared to be about 6 . Changes in soluble elemental composition of dilutions of RP-BR and WP-F smoke-dosed well water are shown in Tables 11 and 12 , respectively.

Significant losses from the $40 \%$ dilution of each burn are further summarized on a molar basis in Table 13. The precipitated material approaches a $1: 1$ ratio of $\mathrm{P}$ to $\mathrm{Ca}$. Although $\mathrm{Sr}$ losses are minor on a mass basis, they represent $21 \%$ to $57 \%$ of the initial soluble concentration. It. is likely that $\mathrm{Sr}$ could be used as an eariy indication of precipitation hefore the event becomes visually evident. A fresh $40 \%$ dilution from WP-F well water stock more closely resembled the day 0 dilution, as expected, since the unneutraljzed stock solutions did not show signs of precipitation. 


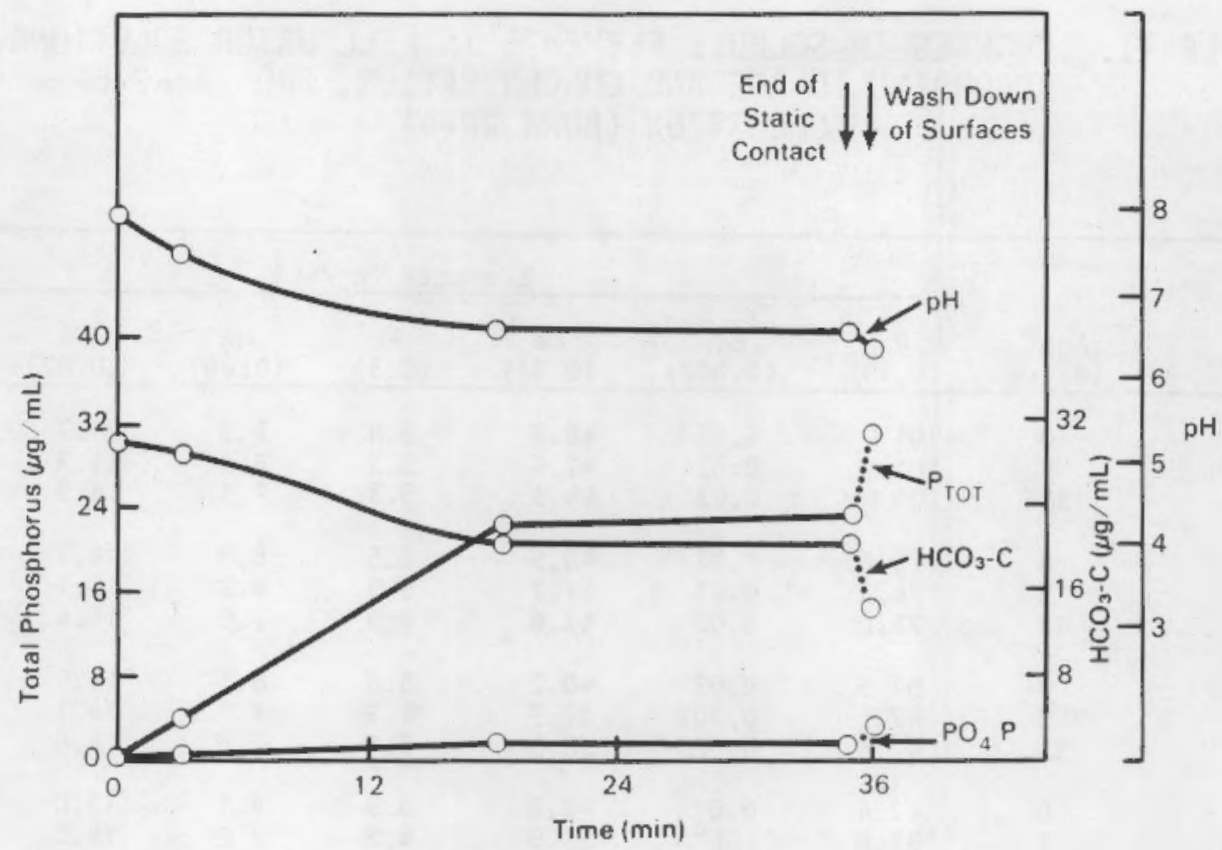

Figure 6. Change in dilution water following settling of RP-BR smoke (Burn RP-1).

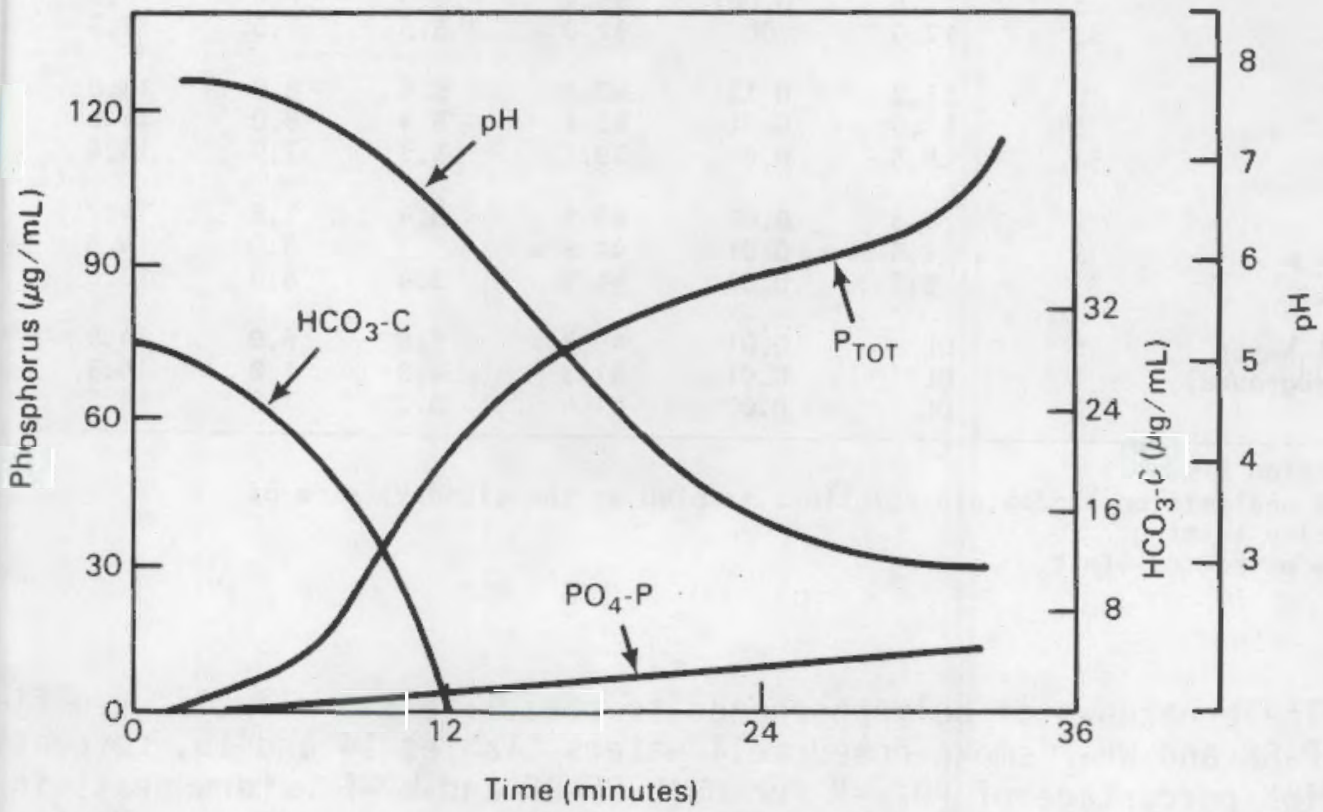

Figure 7. Effect of RP-BR smoke bubbled through well water (117 $\mathrm{mg} / \mathrm{L}$ alkalinity). 
TABLE 11. CHANGES IN SOLUBLE ELEMENTS IN WELL WATER SOLUTIONS, A.CCORDING TO AGE AND CONCENTRATION, FROM A RP-BR

COMBUSTION (BURN RP-4)

\begin{tabular}{|c|c|c|c|c|c|c|c|c|}
\hline \multirow[b]{2}{*}{ Solution } & \multirow[b]{2}{*}{$\begin{array}{l}\text { Age } \\
\text { (days) }\end{array}$} & \multicolumn{7}{|c|}{ El enents $(\mu \mathrm{g} / \mathrm{mL})$} \\
\hline & & $(0.1)^{\mathrm{P}}$ & $\begin{array}{c}\mathrm{Ba} \\
(0.002)\end{array}$ & $\begin{array}{c}\mathrm{Ca}_{\mathrm{a}} \\
(0.01)\end{array}$ & $\begin{array}{c}k \\
(0.3)\end{array}$ & $\begin{array}{c}\mathrm{Mg} \\
(0.06)\end{array}$ & $\begin{array}{c}5 i \\
(0.02) \\
\end{array}$ & $\begin{array}{c}S r \\
(0.001)\end{array}$ \\
\hline Stock & $\begin{array}{c}0 \\
5 \\
33^{b}\end{array}$ & $\begin{array}{l}101 \\
101 \\
104\end{array}$ & $\begin{array}{l}0.05 \\
0.02 \\
0.03\end{array}$ & $\begin{array}{l}40.6 \\
41.6 \\
44.3\end{array}$ & $\begin{array}{l}5.4 \\
5.5 \\
5.3\end{array}$ & $\begin{array}{l}7.9 \\
8.0 \\
7.8\end{array}$ & $\begin{array}{l}14.7 \\
14.7 \\
14.9\end{array}$ & $\begin{array}{l}0.17 \\
0.17 \\
0.17\end{array}$ \\
\hline $70 \%$ & $\begin{array}{r}0 \\
5 \\
33\end{array}$ & $\begin{array}{l}73.6 \\
74.3 \\
71.0\end{array}$ & $\begin{array}{l}0.02 \\
0.01 \\
0.02\end{array}$ & $\begin{array}{l}40.5 \\
41.7 \\
42.6\end{array}$ & $\begin{array}{l}5.5 \\
5.9 \\
4.9\end{array}$ & $\begin{array}{l}8.0 \\
8.2 \\
7.9\end{array}$ & $\begin{array}{l}14.7 \\
15.1 \\
14.4\end{array}$ & $\begin{array}{l}0.17 \\
0.17 \\
0.16\end{array}$ \\
\hline $50 \%$ & $\begin{array}{r}0 \\
5 \\
33\end{array}$ & $\begin{array}{l}52.5 \\
47.2 \\
47.8\end{array}$ & $\begin{array}{l}0.02 \\
0.002 \\
0.005\end{array}$ & $\begin{array}{l}40.2 \\
37.9 \\
38.5\end{array}$ & $\begin{array}{l}5.8 \\
4.9 \\
5.1\end{array}$ & $\begin{array}{l}8.1 \\
7.8 \\
7.8\end{array}$ & $\begin{array}{l}14.9 \\
14.1 \\
14.4\end{array}$ & $\begin{array}{l}0.16 \\
0.13 \\
0.12\end{array}$ \\
\hline $40 \%$ & $\begin{array}{r}0 \\
5 \\
33\end{array}$ & $\begin{array}{l}42.4 \\
33.6 \\
30.7\end{array}$ & $\begin{array}{l}0.01 \\
D L \\
D L\end{array}$ & $\begin{array}{l}40.3 \\
33.9 \\
29.2\end{array}$ & $\begin{array}{l}5.9 \\
4.8 \\
5.3\end{array}$ & $\begin{array}{l}8.1 \\
7.6 \\
7.4\end{array}$ & $\begin{array}{l}15.0 \\
14.2 \\
14.2\end{array}$ & $\begin{array}{l}0.16 \\
0.09 \\
0.07\end{array}$ \\
\hline $30 \%$ & $\begin{array}{r}0 \\
5 \\
33\end{array}$ & $\begin{array}{l}31.5 \\
25.1 \\
19.5\end{array}$ & $\begin{array}{l}0.01 \\
0.006 \\
\text { DL }\end{array}$ & $\begin{array}{l}40.3 \\
35.7 \\
28.4\end{array}$ & $\begin{array}{l}5.8 \\
5.1 \\
5.3\end{array}$ & $\begin{array}{l}8.1 \\
7.7 \\
7.3\end{array}$ & $\begin{array}{l}15.0 \\
14.6 \\
13.6\end{array}$ & $\begin{array}{l}0.16 \\
0.12 \\
0.08\end{array}$ \\
\hline $20 \%$ & $\begin{array}{r}0 \\
5 \\
33\end{array}$ & $\begin{array}{l}20.4 \\
16.8 \\
12.0\end{array}$ & $\begin{array}{l}0.02 \\
0.007 \\
D L\end{array}$ & $\begin{array}{l}40.1 \\
38.4 \\
32.0\end{array}$ & $\begin{array}{l}5.5 \\
5.0 \\
5.5\end{array}$ & $\begin{array}{l}8.0 \\
7.8 \\
7.5\end{array}$ & $\begin{array}{l}14.7 \\
14.3 \\
12.3\end{array}$ & $\begin{array}{l}0.16 \\
0.14 \\
0.11\end{array}$ \\
\hline 108 & $\begin{array}{r}0 \\
5 \\
33\end{array}$ & $\begin{array}{r}11.2 \\
10.0 \\
8.5\end{array}$ & $\begin{array}{l}0.13 \\
0.01 \\
0.01\end{array}$ & $\begin{array}{l}40.3 \\
41.1 \\
39.1\end{array}$ & $\begin{array}{l}5.6 \\
5.4 \\
5.3\end{array}$ & $\begin{array}{l}8.0 \\
8.0 \\
7.9\end{array}$ & $\begin{array}{l}14.8 \\
14.5 \\
13.4\end{array}$ & $\begin{array}{l}0.16 \\
0.16 \\
0.14\end{array}$ \\
\hline $5 \%$ & $\begin{array}{r}0 \\
5 \\
33\end{array}$ & $\begin{array}{l}4.3 \\
4.5 \\
5.2\end{array}$ & $\begin{array}{l}0.01 \\
0.01 \\
0.02\end{array}$ & $\begin{array}{l}40.1 \\
41.9 \\
44.4\end{array}$ & $\begin{array}{l}5.4 \\
5.2 \\
5.4\end{array}$ & $\begin{array}{l}7.9 \\
8.0 \\
8.0\end{array}$ & $\begin{array}{l}14.7 \\
14.5 \\
13.6\end{array}$ & $\begin{array}{l}0.16 \\
0.16 \\
0.16\end{array}$ \\
\hline $\begin{array}{l}\text { Well Water } \\
\text { (Background) }\end{array}$ & $\begin{array}{r}0 \\
5 \\
33\end{array}$ & $\begin{array}{l}D L \\
D L \\
D L\end{array}$ & $\begin{array}{l}0.01 \\
0.01 \\
0.02\end{array}$ & $\begin{array}{l}40.3 \\
41.3 \\
41.4\end{array}$ & $\begin{array}{l}5.8 \\
4.9 \\
5.2\end{array}$ & $\begin{array}{l}8.0 \\
7.8 \\
7.9\end{array}$ & $\begin{array}{l}14.9 \\
14.3 \\
14.5\end{array}$ & $\begin{array}{l}0.16 \\
0.15 \\
0.16\end{array}$ \\
\hline
\end{tabular}

Detection limit.

Final analysis on 33-day-old solutions sampled at the (26-day) time of

toxicity testing.

c Below detection limit.

The breakdown of polyphosphates to phosphate was slow, as typified by the RP-BR and WP-F smoke-dosed well waters (Tables 14 and 15, respectively). The high percentage of $\mathrm{PO}_{4}^{3-}-\mathrm{P}$ for both $\mathrm{RP}-\mathrm{BR}$ and $\mathrm{WP}-\mathrm{F}$ waters peaks in the $50 \%$ dilution concentration. Precipitation is just becoming evident at that concentration and is heaviest, visually, in the $40 \%$ and $30 \%$ dilutions. The 
TABLE 12. CHANGE IN SOLUBLE ELEMENTS IN WELL WATER SOLUTIONS, ACCORDING TO AGE AND CONCENTRATION, FROM A WP-F COMBUSTION (BURN WP-5)

\begin{tabular}{|c|c|c|c|c|c|c|c|c|}
\hline \multirow[b]{2}{*}{ Solution } & \multirow[b]{2}{*}{$\begin{array}{l}\text { Age } \\
\text { (days) }\end{array}$} & \multicolumn{7}{|c|}{ Elements $(\mathrm{gg} / \mathrm{mL}\}$} \\
\hline & & $\stackrel{P}{(0.1)^{a}}$ & $\begin{array}{c}\mathrm{Ba} \\
(0.002)\end{array}$ & $\begin{array}{c}\mathrm{Ca}_{\mathrm{a}} \\
(0.01)\end{array}$ & $\begin{array}{c}k \\
(0.3)\end{array}$ & $\begin{array}{c}\mathrm{Mg} \\
(0.06) \\
\end{array}$ & $\begin{array}{c}5 i \\
(0.02) \\
\end{array}$ & $\begin{array}{c}5 r \\
(0.001) \\
\end{array}$ \\
\hline Stock & $\begin{array}{r}0 \\
5 \\
28\end{array}$ & $\begin{array}{l}101 \\
104 \\
101\end{array}$ & $\begin{array}{l}0.01 \\
0.02 \\
0.02\end{array}$ & $\begin{array}{l}41.2 \\
42.1 \\
41.2\end{array}$ & $\begin{array}{l}5.0 \\
5.1 \\
4.5\end{array}$ & $\begin{array}{l}7.7 \\
8.0 \\
7.8\end{array}$ & $\begin{array}{l}14.1 \\
14.6 \\
14.2\end{array}$ & $\begin{array}{l}0.16 \\
0.17 \\
0.18\end{array}$ \\
\hline 708 & $\begin{array}{r}0 \\
5 \\
28\end{array}$ & $\begin{array}{l}71.7 \\
71.7 \\
70.4\end{array}$ & $\begin{array}{l}0.03 \\
0.01 \\
0.01\end{array}$ & $\begin{array}{l}41.4 \\
41.6 \\
41.0\end{array}$ & $\begin{array}{l}5.0 \\
5.3 \\
5.0\end{array}$ & $\begin{array}{l}7.7 \\
7.8 \\
7.9\end{array}$ & $\begin{array}{l}14.1 \\
14.2 \\
14.3\end{array}$ & $\begin{array}{l}0.16 \\
0.18 \\
0.14\end{array}$ \\
\hline $50 \%$ & $\begin{array}{r}0 \\
5 \\
28\end{array}$ & $\begin{array}{l}51.1 \\
51.1 \\
48.9\end{array}$ & $\begin{array}{l}0.02 \\
0.01 \\
0.01\end{array}$ & $\begin{array}{l}41.1 \\
39.9 \\
38.0\end{array}$ & $\begin{array}{l}5.2 \\
5.1 \\
5.0\end{array}$ & $\begin{array}{l}7.7 \\
7.8 \\
7.8\end{array}$ & $\begin{array}{l}14.1 \\
14.3 \\
14.2\end{array}$ & $\begin{array}{l}0.16 \\
0.14 \\
0.12\end{array}$ \\
\hline $40 \%$ & $\begin{array}{r}0 \\
5 \\
28\end{array}$ & $\begin{array}{l}40.3 \\
37.0 \\
36.2\end{array}$ & $\begin{array}{l}0.02 \\
0.01 \\
0.01\end{array}$ & $\begin{array}{l}40.7 \\
35.6 \\
35.2\end{array}$ & $\begin{array}{l}5.2 \\
5.0 \\
5.0\end{array}$ & $\begin{array}{l}7.6 \\
7.5 \\
7.8\end{array}$ & $\begin{array}{l}14.0 \\
14.1 \\
14.5\end{array}$ & $\begin{array}{l}0.15 \\
0.11 \\
0.12\end{array}$ \\
\hline 308 & $\begin{array}{r}0 \\
5 \\
28\end{array}$ & $\begin{array}{l}30.0 \\
26.1 \\
24.9\end{array}$ & $\begin{array}{l}0.02 \\
0.01 \\
0.01\end{array}$ & $\begin{array}{l}40.4 \\
33.6 \\
33.5\end{array}$ & $\begin{array}{l}5.2 \\
5.1 \\
4.7\end{array}$ & $\begin{array}{l}7.7 \\
7.5 \\
7.6\end{array}$ & $\begin{array}{l}13.9 \\
14.4 \\
14.6\end{array}$ & $\begin{array}{l}0.15 \\
0.09 \\
0.11\end{array}$ \\
\hline $20 q^{(b)}$ & $\begin{array}{r}0 \\
2 \theta\end{array}$ & $\begin{array}{l}20.0 \\
13.9\end{array}$ & $\begin{array}{r}0.01 \\
<0.03\end{array}$ & $\begin{array}{l}40.5 \\
32.8\end{array}$ & $\begin{array}{l}5.1 \\
4.8\end{array}$ & $\begin{array}{l}7.6 \\
7.6\end{array}$ & $\begin{array}{l}14.0 \\
14.6\end{array}$ & $\begin{array}{l}0.15 \\
0.10\end{array}$ \\
\hline $1 \log _{8}(b)$ & $\begin{array}{l}0 \\
28\end{array}$ & $\begin{array}{l}9.8 \\
7.3\end{array}$ & $\begin{array}{r}0.01 \\
<0.01\end{array}$ & $\begin{array}{l}40.6 \\
36.1\end{array}$ & $\begin{array}{l}4.9 \\
5.0\end{array}$ & $\begin{array}{l}7.6 \\
7.6\end{array}$ & $\begin{array}{l}14.1 \\
14.2\end{array}$ & $\begin{array}{l}0.15 \\
0.11\end{array}$ \\
\hline $\begin{array}{l}\text { Well Water } \\
\text { Background }\end{array}$ & $\begin{array}{l}0 \\
5 \\
28\end{array}$ & $\begin{array}{l}0.4 \\
0.2 \\
0.4\end{array}$ & $\begin{array}{l}0.01 \\
0.01 \\
0.01\end{array}$ & $\begin{array}{l}40.3 \\
39.1 \\
40.3\end{array}$ & $\begin{array}{l}4.7 \\
4.8 \\
4.6\end{array}$ & $\begin{array}{l}7.6 \\
7.7 \\
7.8\end{array}$ & $\begin{array}{l}14.0 \\
14.3 \\
14.1\end{array}$ & $\begin{array}{l}0.14 \\
0.14 \\
0.13\end{array}$ \\
\hline $\begin{array}{l}40 \text { made fresh } \\
\text { from stock } \\
\text { on day of tost }\end{array}$ & $\begin{array}{l}5 \\
2 \theta\end{array}$ & $\begin{array}{l}40.4 \\
41.6\end{array}$ & $\begin{array}{l}0.02 \\
0.01\end{array}$ & $\begin{array}{l}38.9 \\
40.6\end{array}$ & $\begin{array}{l}5.2 \\
5.2\end{array}$ & $\begin{array}{l}7.7 \\
8.0\end{array}$ & $\begin{array}{l}14.7 \\
14.5\end{array}$ & $\begin{array}{l}0.13 \\
0.13\end{array}$ \\
\hline
\end{tabular}

Detection limits.

b Twenty and 10\% solutions mere not analyzed on doy 5 .

drop in $P 0$ a $^{-}-\mathrm{P}$ percentage of soluble $P$, in the lower dilutions, does not necessarily indicate that the precipitating species are phosphates. The phenomenon suggests that concentration of phosphorus combustion products represents a critical factor in precipitation and may be related to the resultant $\mathrm{pH}$.

Precipitation was dramatic upon neutralization and was followed by a gradual decrease in solubility of $\mathrm{P}$ and $\mathrm{Ca}$ (Table 16). The precipitated material was not fully characterized, but the observed changes were 
TABLE 13. SIGNIFICANT LOSSES IN SOLUBILITY WITH TIME FOR DILUTED (40\%), NON-NEUTRALIZED 331 WELL WATER ALIQUOTS

\begin{tabular}{|c|c|c|}
\hline \multirow[b]{2}{*}{ Element } & \multicolumn{2}{|c|}{ mM Drop in Solubility } \\
\hline & $W P-F$ & RP-BR \\
\hline $\begin{array}{l}\mathrm{P} \\
\mathrm{Ca} \\
\mathrm{Mg} \\
\mathrm{K} \\
\mathrm{Sr}\end{array}$ & $\begin{array}{l}0.13 \\
0.14 \\
(-0-) \\
0.004 \\
0.0003\end{array}$ & $\begin{array}{l}0.38 \\
0.28 \\
0.03 \\
0.015 \\
0.001\end{array}$ \\
\hline $\begin{array}{l}\text { Initial P Tota? } \\
\text { Age (Days) }\end{array}$ & $28^{---}$ & 1.37 \\
\hline
\end{tabular}

consistent with the formation of amorphous alkaline earth compounds and/or mixed salts of tripolyphosphates and pentapolyphosphates (Van Wazer 1958).

Hydrolys is of polyphosphates in R.P-BR and WP-F smoke-dosed waters proceeded to phosphate slowly. Although long-term hydrolysis studies were outside the scope of this project, a number of stock solutions were periodically re-analyzed for phosphate to determine what portion of the polyphosphates had undergone complete hydrolysis. Since these observations were mainly for jliustrative purposes, samples were merely capped and stored at room temperature between analyses; this handing of samples fails to provide the sterility and environmental control necessary for valid hydrolysis studies.

The results can best be described as a scatter of rates not correlated to water type, phosphorus type burned, or $\mathrm{pH}$ (neutralized versus nonneutralized). Such results illustrate the range of responses seen with aging and also emphasize the current lack of understanding of the mechanisms involved.

Several solutions from WP-F burns were analyzed for elemental P (i.e., $P_{4}$ ) using solvent extraction and ICP detection of P. Results usually were bordering on the ICP detection limit, but appeared to represent no more than $0.01 \%$ of the total $P$ in solution. 
TABLE 14. COMPARISON OF POZ $3^{-}$P TO TOTAL P IN RP-BR SMOKE CONTACTED WITH WELL WATER, AS A FUNCTION OF SOLUTION AGE AND DILUTION

\begin{tabular}{|c|c|c|c|c|c|}
\hline Dilution & Day & $\mathrm{pH}$ & $\begin{array}{l}\text { Total p } \\
(\mu g / m L)\end{array}$ & $\begin{array}{r}P 0 z^{-}-P \\
(\mu g / m L)\end{array}$ & $\begin{array}{l}\mathrm{P} 0 \mathrm{~B}^{-}-\mathrm{P} / \\
\text { Tota1 } \mathrm{P}(\%)\end{array}$ \\
\hline Stock & $\begin{array}{r}0 \\
5 \\
26\end{array}$ & $\begin{array}{l}3.2 \\
3.3 \\
3.1\end{array}$ & $\begin{array}{l}101 \\
101 \\
103\end{array}$ & $\begin{array}{l}13.6 \\
14.6 \\
21.1\end{array}$ & $\begin{array}{l}13.5 \\
14.5 \\
20.5\end{array}$ \\
\hline $70 \%$ & $\begin{array}{r}0 \\
5 \\
26\end{array}$ & $\begin{array}{l}5.1 \\
4.9 \\
5.1\end{array}$ & $\begin{array}{l}73.1 \\
74.3 \\
71.0\end{array}$ & $\begin{array}{r}9.7 \\
10.4 \\
15.2\end{array}$ & $\begin{array}{l}13.2 \\
14.1 \\
21.5\end{array}$ \\
\hline $50 \%$ & $\begin{array}{r}0 \\
5 \\
26\end{array}$ & $\begin{array}{l}6.2 \\
7.0 \\
7.0\end{array}$ & $\begin{array}{l}52.5 \\
47.2 \\
47.8\end{array}$ & $\begin{array}{r}7.0 \\
7.8 \\
16.4\end{array}$ & $\begin{array}{l}13.3 \\
16.6 \\
34.4\end{array}$ \\
\hline $40 \%$ & $\begin{array}{r}0 \\
5 \\
26\end{array}$ & $\begin{array}{l}6.6 \\
7.5 \\
7.5\end{array}$ & $\begin{array}{l}42.4 \\
33.6 \\
30.7\end{array}$ & $\begin{array}{l}5.6 \\
5.7 \\
7.7\end{array}$ & $\begin{array}{l}13.1 \\
17.0 \\
25.2\end{array}$ \\
\hline $30 \%$ & $\begin{array}{r}0 \\
5 \\
26\end{array}$ & $\begin{array}{l}6.8 \\
8.0 \\
8.0\end{array}$ & $\begin{array}{l}31.5 \\
25.1 \\
19.5\end{array}$ & $\begin{array}{l}4.3 \\
4.1 \\
5.3\end{array}$ & $\begin{array}{l}13.3 \\
16.3 \\
27.4\end{array}$ \\
\hline $20 \%$ & $\begin{array}{r}0 \\
5 \\
26\end{array}$ & $\begin{array}{l}7.0 \\
8.1 \\
8.2\end{array}$ & $\begin{array}{l}20.4 \\
16.8 \\
12.0\end{array}$ & $\begin{array}{l}2.7 \\
2.7 \\
3.6\end{array}$ & $\begin{array}{l}13.1 \\
15.8 \\
30.0\end{array}$ \\
\hline $10 \%$ & $\begin{array}{r}0 \\
5 \\
26\end{array}$ & $\begin{array}{l}7.6 \\
8.3 \\
8.3\end{array}$ & $\begin{array}{r}11.2 \\
10.0 \\
8.5\end{array}$ & $\begin{array}{l}1.5 \\
1.5 \\
2.1\end{array}$ & $\begin{array}{l}13.1 \\
15.2 \\
24.9\end{array}$ \\
\hline $5 \%$ & $\begin{array}{r}0 \\
5 \\
26\end{array}$ & $\begin{array}{l}7.6 \\
8.4 \\
8.4\end{array}$ & $\begin{array}{l}4.3 \\
4.5 \\
5.2\end{array}$ & $\begin{array}{l}0.6 \\
0.7 \\
1.4\end{array}$ & $\begin{array}{l}14.3 \\
14.7 \\
27.7\end{array}$ \\
\hline $\begin{array}{l}\text { Well Water } \\
\text { (background) }\end{array}$ & $\begin{array}{r}0 \\
5 \\
26\end{array}$ & $\begin{array}{l}7.9 \\
8.4 \\
8.3\end{array}$ & $\begin{array}{c}(<0.1)^{a} \\
(<0 \\
(<0.1)\end{array}$ & $\begin{array}{l}.05 \\
\text { ND } \\
.03\end{array}$ & $\begin{array}{r}\sim 100 \\
\text { ND } \\
\sim 60\end{array}$ \\
\hline
\end{tabular}

\footnotetext{
${ }^{\text {a Total }} \mathrm{P}$ determined on freeze-dried concentration $(0.05 \mu \mathrm{g} / \mathrm{mL}$ ). $\mathrm{b}_{\mathrm{NC}}=$ not determined.
} 
TABLE 15. COMPARISON OF PO $3^{3}-P$ TO TOTAL P IN WP-F SPIOKE CONTACTED WITH WELL WATER, AS A FUNCTION OF SOLUTION AGE AND DILUTION

\begin{tabular}{|c|c|c|c|c|c|}
\hline Dilution & Day & $\mathrm{pH}$ & $\begin{array}{l}\text { Total p } \\
(\mu \mathrm{g} / \mathrm{mL})\end{array}$ & $\begin{array}{r}\mathrm{PO}_{4}^{3-}-\mathrm{P} \\
(\mathrm{Hg} / \mathrm{mL}) \\
\end{array}$ & $\begin{array}{c}\mathrm{P}_{4} 3^{-}-\mathrm{p} / \\
\text { Total } \mathrm{p}(\%)\end{array}$ \\
\hline Stock & $\begin{array}{r}0 \\
5 \\
28\end{array}$ & $\begin{array}{l}2.9 \\
3.1 \\
3.0\end{array}$ & $\begin{array}{l}101 \\
104 \\
101\end{array}$ & $\begin{array}{l}15.0 \\
15.5 \\
18.8\end{array}$ & $\begin{array}{l}14.9 \\
14.9 \\
18.6\end{array}$ \\
\hline $70 \%$ & $\begin{array}{r}0 \\
5 \\
28\end{array}$ & $\begin{array}{l}4.5 \\
4.7 \\
4.7\end{array}$ & $\begin{array}{l}71.7 \\
71.7 \\
70.4\end{array}$ & $\begin{array}{l}10.3 \\
10.8 \\
15.0\end{array}$ & $\begin{array}{l}14.4 \\
15.1 \\
21.3\end{array}$ \\
\hline $50 \%$ & $\begin{array}{r}0 \\
5 \\
28\end{array}$ & $\begin{array}{l}5.8 \\
6.7 \\
6.9\end{array}$ & $\begin{array}{l}51.1 \\
51.1 \\
48.9\end{array}$ & $\begin{array}{r}7.4 \\
8.0 \\
20.2\end{array}$ & $\begin{array}{l}14.5 \\
15.7 \\
41.3\end{array}$ \\
\hline $40 \%$ & $\begin{array}{r}0 \\
5 \\
28\end{array}$ & $\begin{array}{l}6.3 \\
7.6 \\
7.5\end{array}$ & $\begin{array}{l}40.3 \\
37.0 \\
36.2\end{array}$ & $\begin{array}{l}5.9 \\
6.0 \\
9.9\end{array}$ & $\begin{array}{l}14.6 \\
16.2 \\
27.3\end{array}$ \\
\hline $30 \%$ & $\begin{array}{r}0 \\
5 \\
28\end{array}$ & $\begin{array}{l}6.6 \\
7.8 \\
7.9\end{array}$ & $\begin{array}{l}30.0 \\
26.1 \\
24.9\end{array}$ & $\begin{array}{l}4.4 \\
4.3 \\
5.9\end{array}$ & $\begin{array}{l}14.7 \\
16.5 \\
23.7\end{array}$ \\
\hline $20 \%$ & $\begin{array}{r}0 \\
5 \\
28\end{array}$ & $\begin{array}{l}6.9 \\
8.1 \\
8.2\end{array}$ & $\begin{array}{c}20.0^{0} \\
\text { ND }^{\mathrm{a}} \\
13.8\end{array}$ & $\begin{array}{l}3.0 \\
2.6 \\
4.3\end{array}$ & $\begin{array}{l}15.0 \\
\text { ND } \\
31.4\end{array}$ \\
\hline $10 \%$ & $\begin{array}{r}0 \\
5 \\
28\end{array}$ & $\begin{array}{l}7.3 \\
8.3 \\
8.4\end{array}$ & $\begin{array}{l}9.8 \\
\text { ND } \\
7.27\end{array}$ & $\begin{array}{l}1.5 \\
1.6 \\
2.3\end{array}$ & $\begin{array}{r}15.7 \\
\text { ND } \\
31.6\end{array}$ \\
\hline $\begin{array}{l}\text { Well Water } \\
\text { (background) }\end{array}$ & $\begin{array}{r}0 \\
5 \\
28\end{array}$ & $\begin{array}{l}8.0 \\
8.5 \\
8.5\end{array}$ & $\begin{array}{l}0.4 \\
0.23 \\
0.41\end{array}$ & $\begin{array}{l}0.04 \\
0.05 \\
0.04\end{array}$ & $\begin{array}{l}\sim 11 \\
\sim 22 \\
\sim 10\end{array}$ \\
\hline
\end{tabular}

$a_{i A D}=$ Not determined. 
TABLE 16. PRECIPITATION FROM NEUTRALIZED WELL WATER (117 MG/L ALKAL INITY) AND RECONSTITUTED VERY HARD WATER (230 MG/L AL.KALINITY) AFTER CONTACT WITH WP-F SMOKE

\begin{tabular}{ccc}
\hline & \multicolumn{2}{c}{ Water } \\
\cline { 3 - 3 } Losses of Elements & $\begin{array}{l}\text { Well } \\
\text { Water }\end{array}$ & $\begin{array}{c}\text { Very Hard } \\
\text { Water }\end{array}$ \\
\hline $\begin{array}{c}\text { Inftial (<1 day) } \\
\text { P }\end{array}$ & & \\
Ca & 0.30 & 0.57 \\
Gradual (1-6 days) & 0.22 & 0.56 \\
P & & \\
Ca & 0.14 & 0.05 \\
\hline
\end{tabular}

\section{Speciation}

Separation of the polyphosphate species was implemented after a number of Phase I tests were already completed. Repeated analysis over time of phosphate concentrations (by IC) had revealed that conversion to phosphate was much slower than injtially anticipated. Detection limits for the IC were $0.02 \mathrm{\mu g} / \mathrm{mL}$ for $P 03^{3}-\mathrm{P}, 0.01 \mathrm{\mu g} / \mathrm{mL} P 3_{3}^{3}-\mathrm{P}$ and 0.03 to $0.05 \mathrm{\mu g} / \mathrm{mL} P 02^{3-}-P$.

Separation of polyphosphate species on neutralized and unneutralized WP-F stock solutions in a range of water types is shown in Tables 17 and 18 . These solutions ranged in age from 23 to 93 days since preparation. Earliest HPLC separations (Table 17) employed Nas EDTA-containing eluents in an effort to maximize separation of peaks. This eluent caused the $3 P$ and $4 P$ chains to coelute, however. Later HPLC separations (Table 18) used $\mathrm{Na}_{4}$ EDTA-containing elvents, which successfully separated $3 \mathrm{P}$ and $4 \mathrm{P}$ chains at only a small decrease in retention time intervals of the other polyphosphates. The neutralized stock solutions show a striking change in hydrolysis products. The differences for very hard water were not as dramatic, presumabiy because of the higher initial pH following partial neutralization of the acidic smoke by the constituents of the water. The larger polyphosphate chains have disappeared in the neutralized stocks, while the level of cyclic trimetaphosphate is greatiy enhanced, and small amounts of tetra- and hexametaphosphate are suspected. The observed levels 
TABLE 17. DISTRIBUTION OF PHOSPHORUS SPECIES IN NEUTRALIZED AND NONNEUTRALIZED WP-F SOLUTIONS FROM SMOKE CONTACTS AFTER AGING

\begin{tabular}{|c|c|c|c|c|c|c|}
\hline \multirow[b]{2}{*}{$\mathrm{pH}$ (initial) } & \multicolumn{2}{|c|}{$\begin{array}{r}\text { We } 11 \text { Water } \\
\text { at } 39 \text { days } \\
\end{array}$} & \multicolumn{2}{|c|}{$\begin{array}{l}\text { Very Hard Water } \\
\text { at } 40 \text { days }\end{array}$} & \multicolumn{2}{|c|}{$\begin{array}{l}\text { Hard Water } \\
\text { at } 23 \text { days }\end{array}$} \\
\hline & 2.8 & 7.7 & 4.9 & 8.1 & 2.6 & 8.0 \\
\hline p Species ${ }^{a}$ & - - & -- & $-\underset{\infty}{\alpha} / \mathrm{P}$ & -- & -- & \\
\hline $\begin{array}{l}1 P \\
2 P \\
3+4 P \\
5 P \\
6 P \\
7 P \\
8 P \\
9 P+6 m P \\
10 P+4 m P \\
11 P \\
12 P \\
13 P+3 m P \\
\geq 14 P\end{array}$ & $\begin{array}{r}22.1 \\
23.0 \\
26.8 \\
5.5 \\
4.1 \\
3.8 \\
2.8 \\
2.6 \\
1.9 \\
1.1 \\
0.7 \\
3.8 \\
1.7\end{array}$ & $\begin{array}{c}22.8 \\
20.0 \\
40.9 \\
<\mathrm{DL} b \\
0.6 \\
0.4 \\
0.1 \\
0.7 \\
0.5 \\
<\mathrm{DL} \\
<\mathrm{DL} \\
14.1 \\
<\mathrm{DL}\end{array}$ & $\begin{array}{r}22.8 \\
19.4 \\
36.1 \\
1.8 \\
0.4 \\
0.1 \\
0.2 \\
0.9 \\
0.6 \\
<D L \\
<D L \\
17.8 \\
<D L\end{array}$ & $\begin{array}{c}30.3 \\
16.0 \\
38.6 \\
<D L \\
<D L \\
<D L \\
<D L \\
0.5 \\
0.6 \\
<D L \\
<D L \\
14.2 \\
<D L\end{array}$ & $\begin{array}{r}19.6 \\
16.3 \\
21.0 \\
7.5 \\
6.2 \\
5.2 \\
4.8 \\
4.5 \\
3.3 \\
2.6 \\
1.9 \\
3.3 \\
2.8\end{array}$ & $\begin{array}{r}21.7 \\
12.3 \\
31.9 \\
5.9 \\
1.6 \\
0.9 \\
<\mathrm{DL} \\
1.0 \\
0.7 \\
<\mathrm{DL} \\
<\mathrm{DL} \\
24.2 \\
<\mathrm{DL} .\end{array}$ \\
\hline
\end{tabular}

of phosphate with age gave little indication of the change in hydrolysis in neutralized solutions with time. Apparently a rate-determining step in overall hydrolysis could involve the $3 P$ and $3 \mathrm{mP}$ species (Table 18).

Speciations of RP-BR combustion products was conducted with the stock solution generated in the first trial burn on this project and on a smokedosed deionized water. Apparently, the salt content (Ca, etc.) of the well water has some stabilizing effect on the polyphosphate species, such that even after 6 months there were measurable levels of chains up to $12 \mathrm{P}$ (Table 19). Early breakdown of long-chain polyphosphates was demonstrated by speciation of deionized water dosed sample over a 9-day period. Phosphate formation in distilled water dosed with WP-F smoke (Burn WP-7) 
TABLE 18. DISTRIBUTION OF PHOSPHORUS SPECIES IN HARD WATER SOLUTIONS USING $\mathrm{Na}_{4}$ EDTA ETuents

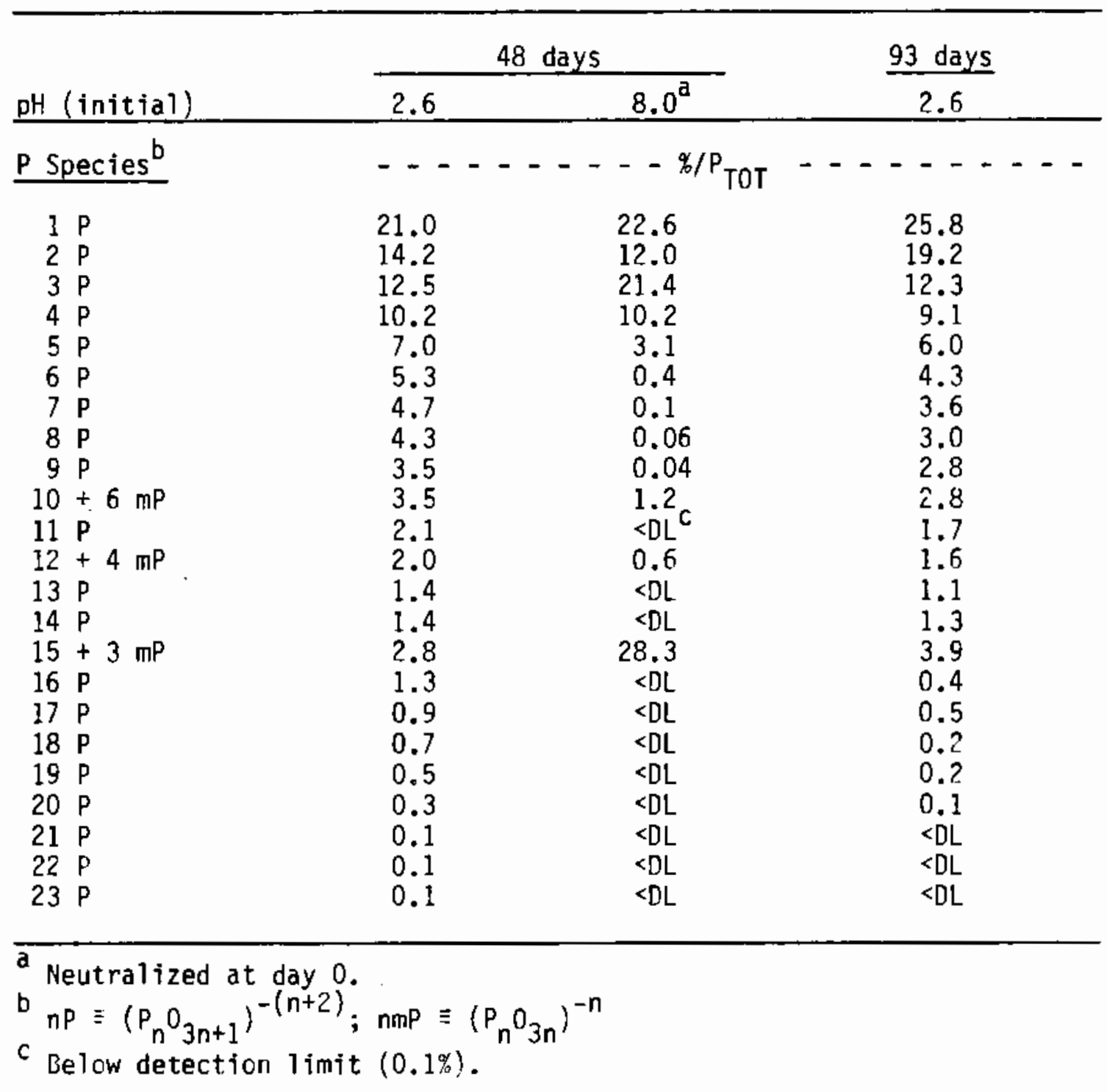


TABLE 19. PHOSPHORLS DISTRIBUTION WITH TIME IN RP-BR SHOKE CONTACTED WATERS

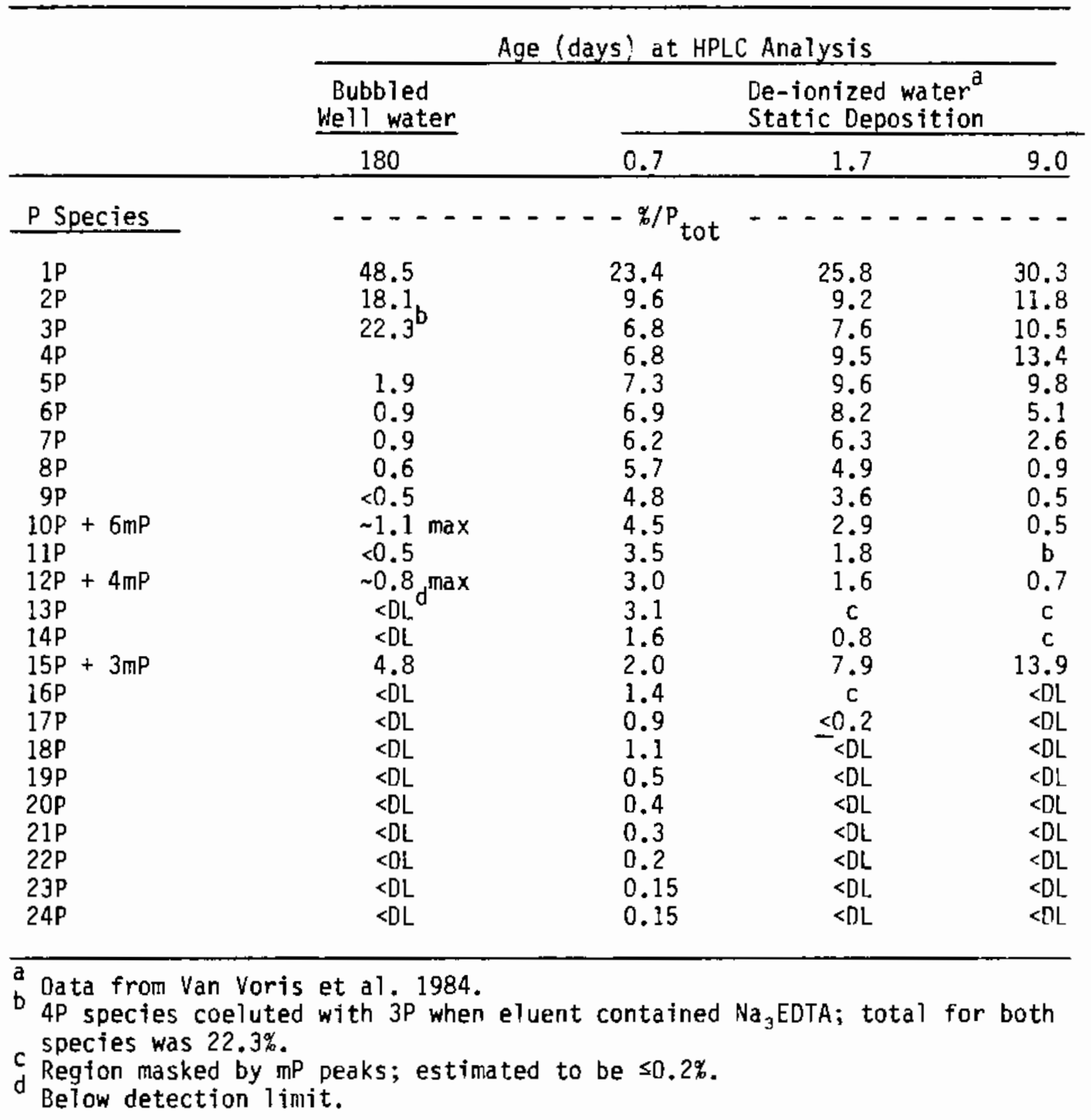


showed a similar rate of hydrolysis over a 1-month period to that of a well water dosed during the same test.

\section{Phase I and Phase II Stock Generations}

Tables 20 and 21 summarize the phosphorus data taken for the stock solutions used in Phase I and Phase II testing, respectively. Changes with dilution in percentage of $P$ as phosphate or phosphite were minor when analyzed fresh and precipitation had not occurred. The phosphate levels generated in Phase I testing (Table 20) did not follow any trend versus water hardness or smoking agent, but were influenced by run-to-run differences that likely occurred during smoke generation. Phosphate levels during Phase II tests (Table 21) were generally higher than during Phase I tests, at least partly due to the change in smoke dosing configuration and settling time in the 760-L Fusion carboys. It is not known whether an increase in trimetaphosphate also occurred, or whether the breakdown of polyphosphates in these unneutralized solutions proceeded primarily to the shorter chain (2P-6F) linear polyphosphates.

The higher level of phosphite generated during Phase I RP-BR versus WP-F smoke-dosed waters was generally repeated in Phase II tests, though the difference was not as significant and the spread in sample values was greater. Apparently there was enough of a difference in the combustion of WP-F to keep the phosphite production minimized.

\subsubsection{Toxicity}

This section covers the toxic effects of P-based obscurants. Phase I testing covered preliminary tests with D. magna on the interactions among water quality, aging of exposure solutions and toxicity. The abflity of phosphorus smoke to acidify water was related to the buffering capacity of the water. Precipitation of $P$ and alkaline earth elements was more prevalent in the more buffered waters. Phase II consisted of definitive toxicity tests with four species of $\mathrm{fish}$, four species of invertebrates and a green algae.

\section{Phase I Tests}

During Phase I of the project, several tests were performed to evaluate the mode of toxicity of these obscurants. Daphnia magna was the only species tested during these tests. The battery of tests performed included 96-hr toxicity screening tests, tests on the effects of buffering capacity of the diluent on toxicity, and the effects of aging of exposure solutions on toxicity.

Initial iests. The initial tests performed in well water with $\underline{D}$. magna were conducted for $96-\mathrm{hr}$. A bimodal response was noted (Table 22) indicating that within the initial $48 \mathrm{hr}$ of exposure, the principal toxic effect was related to acidification resulting from hydrolysis of the 
TABLE 20. RP-BR AND WP-F STOCK SOLUTIONS USED WITH DAPHNIA MAGNA TOXICITY TESTS DURING PHASE I

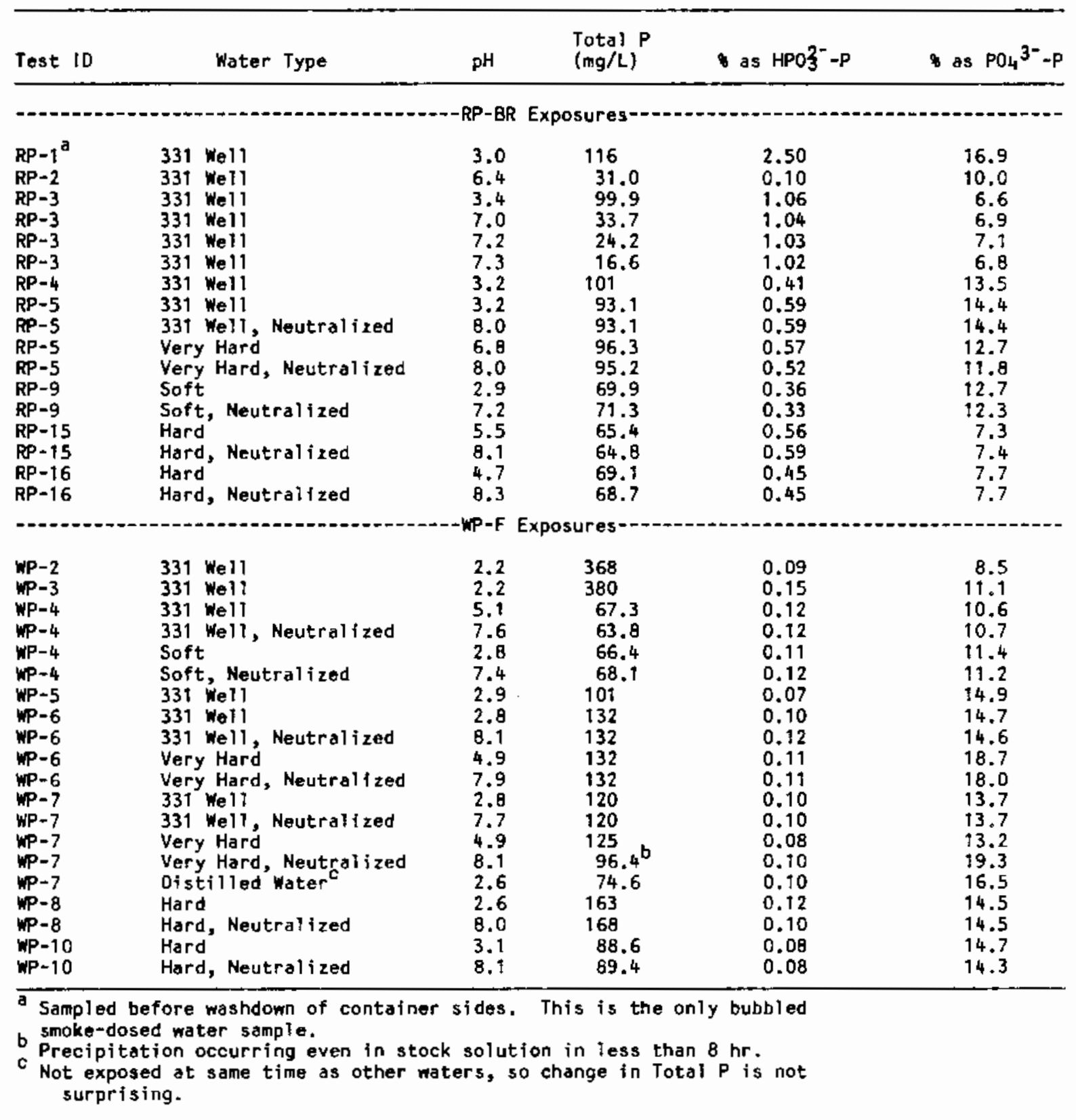


TABLE 21. RP-BR AND WP-F STOCK SOLUTIONS USED DIJRING PHASE II TESTS WITH COLUMBIA RIVER, WATER

\begin{tabular}{|c|c|c|c|c|c|}
\hline Test ID & Species & $\mathrm{pH}$ & $\begin{array}{l}\text { Total P } \\
\text { (mg/L) }\end{array}$ & $\%$ as $\mathrm{HPO}_{3}^{-}-\mathrm{P}$ & $\%$ as $\mathrm{P}_{4} 3^{-}-\mathrm{P}$ \\
\hline $\begin{array}{l}R P-9 \\
R P-13 \\
R P-12 \\
R P-12\end{array}$ & $\begin{array}{l}\text { D. magna } \\
\frac{\text { Hexagenia }}{\text { H. azteca }} \text { sp. } \\
\text { P. } \frac{\text { dissimilus }}{\text { dissing }}\end{array}$ & $\begin{array}{l}4.4 \\
2.9 \\
3.2 \\
3.2\end{array}$ & $\begin{array}{l}34.4 \\
148 \\
60 \\
60\end{array}$ & $\begin{array}{l}0.06 \\
0.67 \\
0.21 \\
0.21\end{array}$ & $\begin{array}{l}6.8 \\
15.1 \\
12.3 \\
12.3\end{array}$ \\
\hline $\begin{array}{l}R P-10 \\
R P-16 \\
R P-11 \\
R P-14 \\
R P-12\end{array}$ & $\begin{array}{l}\text { P. promelas } \\
\text { S. } \frac{\text { gairdneri }}{\text { I. }} \\
\frac{\text { punctatus }}{\text { I. }} \cdot \frac{\text { punctatus }}{\text { Lacrochirus }}\end{array}$ & $\begin{array}{l}2.4 \\
2.4 \\
2.1 \\
2.3 \\
2.1\end{array}$ & $\begin{array}{l}282 \\
198 \\
514 \\
198 \\
537\end{array}$ & $\begin{array}{l}0.22 \\
0.43 \\
0.13 \\
0.63 \\
0.12\end{array}$ & $\begin{array}{l}22.9 \\
19.3 \\
40.3 \\
15.3 \\
34.4\end{array}$ \\
\hline $\begin{array}{l}R P-7 \\
R P-8 \\
R P-14\end{array}$ & $\begin{array}{l}\text { S. } \\
\text { S. capricornutum } \\
\text { s. } \\
\text { capricornutum } \\
\text { capricornutum }\end{array}$ & $\begin{array}{l}7.9^{\mathrm{a}} \\
2.7 \\
2.7\end{array}$ & $\begin{array}{r}75 \\
97 \\
103\end{array}$ & $\begin{array}{l}0.19 \\
0.16 \\
0.69\end{array}$ & $\begin{array}{r}10.3 \\
11.3 \\
8.1\end{array}$ \\
\hline $\begin{array}{l}W P-16^{b} \\
W P-15 \\
W P-14 \\
W P-14\end{array}$ & $\begin{array}{l}\text { D. magna } \\
\frac{\text { Hexagenta }}{\text { H. azteca }} \text { sp. } \\
\underline{p} \cdot \frac{\text { dissimilus }}{\text { diss }}\end{array}$ & $\begin{array}{l}2.5 \\
2.2 \\
2.1 \\
2.1\end{array}$ & $\begin{array}{l}145 \\
410 \\
430 \\
430\end{array}$ & $\begin{array}{l}0.11 \\
0.11 \\
0.13 \\
0.13\end{array}$ & $\begin{array}{l}17.8 \\
20.2 \\
37.9 \\
37.9\end{array}$ \\
\hline $\begin{array}{l}W P-14 \\
W P-15 \\
W P-13 \\
W P-16\end{array}$ & $\begin{array}{l}\frac{P}{S} \cdot \frac{\text { promelas }}{\text { gairdneri }} \\
\text { I. } \\
\text { Lunctatus } \\
\text { macrochirus }\end{array}$ & $\begin{array}{l}2.1 \\
2.2 \\
2.1 \\
2.0\end{array}$ & $\begin{array}{l}447 \\
410 \\
588 \\
548\end{array}$ & $\begin{array}{l}0.05 \\
0.11 \\
0.14 \\
0.08\end{array}$ & $\begin{array}{l}22.0 \\
20.2 \\
30.1 \\
39.0\end{array}$ \\
\hline $\begin{array}{l}\text { WP-11 } \\
W P-14\end{array}$ & $\frac{\text { S. }}{\text { S. }} \cdot \frac{\text { capricornutum }}{\text { capricornutum }}$ & $\begin{array}{l}2.6 \\
2.7\end{array}$ & $\begin{array}{r}125 \\
42.8\end{array}$ & $\begin{array}{l}0.08 \\
0.09\end{array}$ & $\begin{array}{l}13.9 \\
26.0\end{array}$ \\
\hline
\end{tabular}


TABLE 22. BIMODAL RESPONSE OF $\underline{0}$. MAGNA OVER $96 \mathrm{HR}$, BURN RP-5

\begin{tabular}{lccccc}
\hline & & \multicolumn{5}{c}{ Mortality } \\
\cline { 3 - 6 } Dilution & Total P $(\mathrm{mg} / \mathrm{L})^{\mathrm{a}}$ & $24 \mathrm{hr}$ & $48 \mathrm{hr}$ & $72 \mathrm{hr}$ & $96 \mathrm{hr}$ \\
\hline Cont,rol & & 0 & 0 & 0 & 0 \\
$10 \%$ & $(9.3)$ & 0 & 0 & 0 & 0 \\
$30 \%$ & $(27.9)$ & 0 & 0 & 0 & 29.2 \\
$40 \%$ & $(37.2)$ & 0 & 0 & 16.7 & 79.2 \\
$50 \%$ & $(46.6)$ & 0 & 0 & 4.2 & 83.3 \\
$70 \%$ & $(65.2)$ & 33.3 & 91.7 & 100 & 100 \\
$100 \%$ & 93.1 & 100 & 100 & 100 & 100 \\
\hline
\end{tabular}

a

Values in parenthesis are nominal concentrations.

$P$ combustion products in water. At $96 \mathrm{hr}$, non-dose-dependent mortality was observed in the $30 \%$ to $50 \%$ dilutions. Coincident with the mortality was the formation of precipitated material in the exposure beakers and in the gastrointestinal (GI) tract of the exposed daphnids. This generalized mortality pattern was observed in other Phase I tests and may be related to physical effects (accumulation of precipitated material by the organisms), chemical toxicity or a combination of the two factors. This bimodal response was unique to $D$. magna and was not observed in any other species tested during Phase II of the project.

Aging Tests. It was not known how the concentration of phosphorus combustion products in well water would effect the rate of hydrolys is over the duration of the aging tests. Hydrolysis rates may also be influenced by $\mathrm{pH}$. By initially preparing sufficient amounts of exposure solutions for the 26- to 28-day period of testing, the effect that acidjfication would have on stabilization of the combustion products in water was minimized. The $40 \%$ solutions that were prepared at days 5 and 26 served as a check on the toxicity of the more acidified stock solutions ( $\mathrm{pH} \sim 3.0$ ) over time. In the test with WP-F, toxicity observed at $48 \mathrm{hr}$ at the three test periods was principally attributed to $\mathrm{pH}$ (Table 23). That the mortality observed at the $20 \%$ to $50 \%$ solutions for the Day 5 test exceeded the observed mortality for the same solutions at Day 0 may be explained by random variability in the overall sensitivity of the test populations of daphnids. This explanation is supported by the observation that a higher level of mortality was observed at $96 \mathrm{hr}$ in the 20 to $50 \%$ solutions for the Day 0 tests than in the Day 5 test. This implies that the group of daphnids tested at day 5 were more sensitive over all than the 0ay 0 population. This point is further corroborated by the observation that mortality in the control treatment for the Day 5 test. at $96 \mathrm{hr}$ was five times as high as the Day 0 test. The 
TABLE 23. TOXICITY ( $\%$ MORTALITY, $N=24$ ) OF WP-F SMOKE-DOSED WATER TO DAPHNIA MAGNA AS A FUNCTION OF THE AGE OF EXPOSURE SOLUTION (BURN WP-5) ${ }^{\mathrm{a}}$

\begin{tabular}{|c|c|c|c|c|c|}
\hline Treatment & Initial $\mathrm{pH}^{\mathrm{b}}$ & $24 \mathrm{hr}$ & $48 \mathrm{hr}$ & $72 \mathrm{hr}$ & $96 \mathrm{hr}$ \\
\hline $\begin{array}{l}70 \% \\
50 \% \\
40 \% \\
30 \% \\
20 \% \\
10 \% \\
\text { Control }\end{array}$ & $\begin{array}{l}4.61 \\
5.89 \\
6.28 \\
6.56 \\
6.61 \\
7.18 \\
7.95\end{array}$ & $\begin{array}{c}100.0 \% \\
4.28 \\
0 \\
0 \\
4.28 \\
0 \\
0\end{array}$ & $\begin{array}{c}100.08 \\
8.3 \% \\
4.28 \\
0 \\
4.2 \% \\
0 \\
0\end{array}$ & $\begin{array}{c}100.08 \\
50.08 \\
79.28 \\
79.28 \\
79.28 \\
0 \\
0\end{array}$ & $\begin{array}{r}100.08 \\
95.88 \\
100.08 \\
100.08 \\
100.08 \\
29.28 \\
4.28\end{array}$ \\
\hline $\begin{array}{l}70 \% \\
50 \% \\
40 \% \\
30 \% \\
20 \% \\
10 \% \\
\text { Control }\end{array}$ & $\begin{array}{l}4.84 \\
6.83 \\
7.62 \\
7.96 \\
8.21 \\
8.43 \\
8.59\end{array}$ & $\begin{array}{c}100.08 \\
12.58 \\
8.38 \\
4.28 \\
12.58 \\
4.28 \\
0\end{array}$ & $\begin{array}{r}100.0 \% \\
45.8 \% \\
41.7 \% \\
37.5 \% \\
33.3 \% \\
4.28 \\
4.2 \%\end{array}$ & $\begin{array}{r}100.0 \% \\
70.8 \% \\
50.0 \% \\
54.28 \\
37.5 \% \\
4.2 \% \\
8.3 \%\end{array}$ & $\begin{array}{r}100.08 \\
83.5 \% \\
54.28 \\
62.58 \\
50.08 \\
12.58 \\
25.08\end{array}$ \\
\hline $\begin{array}{l}408 \text { from } \\
\text { Doy } 0, \\
\text { filtered }\end{array}$ & 7.73 & 12.58 & 29.28 & 37.58 & $37.5 \%$ \\
\hline $\begin{array}{l}40 \% \text { from } \\
5 \text { day aged } \\
\text { stock solution }\end{array}$ & 6.45 & 8.38 & 50.08 & 87.58 & $100.0 \%$ \\
\hline $\begin{array}{l}70 \% \\
50 \% \\
40 \% \\
30 \% \\
20 \% \\
10 \% \\
\text { Control }\end{array}$ & $\begin{array}{l}4.67 \\
6.94 \\
7.51 \\
7.91 \\
8.21 \\
8.39 \\
8.50\end{array}$ & $\begin{array}{c}100.08 \\
0 \\
0 \\
0 \\
0 \\
0 \\
0\end{array}$ & $\begin{array}{c}100.0 \% \\
4.2 \% \\
0 \\
0 \\
0 \\
0 \\
0\end{array}$ & $\begin{array}{c}100.0 \% \\
4.2 \% \\
0 \\
0 \\
0 \\
0 \\
0\end{array}$ & $\begin{array}{c}100.0 \% \\
4.28 \\
0 \\
0 \\
4.28 \\
0 \\
0\end{array}$ \\
\hline $\begin{array}{l}409 \text { from } \\
28 \text { day aged } \\
\text { stock solution }\end{array}$ & 7.49 & 0 & 0 & $20.8 \%$ & 50.08 \\
\hline
\end{tabular}

See Table 14 for comparison of phosphate and total phosphorous

$b$ concentrations as a function of solution age.

Measured in the exposure beakers. 
bimodal responses noted at $96 \mathrm{hr}$ revealed an effect of aging on the exposure solutions. At 0 and 5 days of aging, there was no apparent difference in response. At 28 days, however, there was a clear and distinctive decrease in toxicity reflected in the 96-hr data.

The same generalized conclusions can be drawn from the aging tests with $R P-B R$ (Table 24). In this series of tests, the observed mortality at $96 \mathrm{hr}$ in the 20 to $50 \%$ dilutions was lower than that observed in the WP-F series at 0 and 5 days aging.

Auxiliary exposures were set up during these tests. Exposure solutions from the $40 \%$ dilutions from the Day 0 test were $f i]$ tered $(0.22 \mu \mathrm{m})$ and retested during the Day 5 tests for WP-F and RB-BR obscurants. At the second and third test in each series, a "fresh" $40 \%$ dilution was prepared from the original day 0 stock solution. The following interpretation is based on the observed toxicity at 72 and $96 \mathrm{hr}$. Toxicity of freshly prepared RP-BR 40\% exposure solutions showed a slight increase over 26 days. The Day 5 auxiliary test beakers were loaded with first daphnid instars after the rest of the test had been set up. This may have introduced some bias into the results, i.e., the apparent increase in toxicity noted in the fresh $40 \%$ solution compared to the aged $40 \%$ solution may be due to the fact that the daphnids remaining after loading the exposure beakers for the Day 5 test may have been weaker organisms. Nonetheless, the difference between the fresh and the aged RP-BR $40 \%$ solutions at 26 days is quite apparent and not biased by loading sequence. In both tests, the filtered $40 \%$ solutions at 5 days were less toxic than the fresh $40 \%$ solutions.

Neutralization Tests. Neutralization tests with $\mathrm{D}$. magna were performed in dilution water with four distinct levels of buffering capacity; well water and three levels of reconstituted water. The buffering capacity of these waters ranged from $50 \mathrm{mg} / \mathrm{L}$ to $225 \mathrm{mg} / \mathrm{L}$ carbonate alkalinity. Because the primary mode of toxicity was acidification and the method of dosing water generaliy resulted in stock solutions with a total $P$ concentration of 70 to $120 \mathrm{mg} / \mathrm{L}$, the pattern of toxic responses as a function of dilution showed an increased sensitivity of first instar D. magna in reconstituted soft water compared to weli water and the more buffered reconstituted waters. A complete accounting of mortality records is located in Appendix $C$.

For comparative purposes, on ty the exposure concentrations showing the highest observed mortality (\%) and the next lowest exposure solution for each type of water are compared in Table 25 . For example, the $30 \%$ solution of reconstituted soft water dosed with WP-F smoke $(19.9 \mathrm{mg} / \mathrm{L}$ total $\mathrm{P}, \mathrm{pH}$ 4.71) was lethal to $100 \%$ of the exposed organisms. The next lower concentration tested usually had 0\% mortality. Overal1, Table 25 gives an indication of how the buffering capacity of the receiving water affects toxicity. There are toxic components present in smoke-dosed water as indicated by the mortality observed in the neutralized and non-neutralized exposure solutions that were tested in all four types of dilution water. 
TABLE 24. TOXICITY ( $\%$ MORTALITY, $n=24$ ) OF RP-BR SMOKE TO DAPHNIA MAGNA AS A FUNCTION OF AGE OF THE EXPOSURE SOLUTIONS

\begin{tabular}{|c|c|c|c|c|c|}
\hline Treatment & Initial $\mathrm{pH}^{\mathrm{a}}$ & $24 \mathrm{hr}$ & $48 \mathrm{hr}$ & $72 \mathrm{hr}$ & $96 \mathrm{hr}$ \\
\hline $70 \%$ & 5.10 & 100.08 & 100.08 & 100.08 & 100.09 \\
\hline $\begin{array}{l}50 \% \\
40 \% \\
308 \\
208 \\
108 \\
5 \% \\
\text { Control }\end{array}$ & $\begin{array}{l}6.25 \\
6.50 \\
6.75 \\
7.01 \\
7.25 \\
7.55 \\
7.90\end{array}$ & $\begin{array}{l}0 \\
0 \\
0 \\
0 \\
0 \\
0 \\
0\end{array}$ & $\begin{array}{l}0 \\
0 \\
0 \\
0 \\
0 \\
0 \\
0\end{array}$ & $\begin{array}{l}12.58 \\
16.78 \\
8.38 \\
4.28 \\
0 \\
0 \\
0\end{array}$ & $\begin{array}{c}25.0 \\
25.08 \\
12.5 \\
4.28 \\
0 \\
0 \\
0\end{array}$ \\
\hline 708 & 4.93 & $69.6 \%$ & 100.08 & 100.08 & 100.0 \\
\hline $\begin{array}{l}508 \\
408 \\
308 \\
208 \\
108 \\
58 \\
\text { Control }\end{array}$ & $\begin{array}{l}7.03 \\
7.52 \\
7.95 \\
8.14 \\
6.29 \\
8.40 \\
8.42\end{array}$ & $\begin{array}{l}0 \\
0 \\
0 \\
0 \\
0 \\
0 \\
0\end{array}$ & $\begin{array}{l}0 \\
0 \\
4.28 \\
0 \\
0 \\
0 \\
0\end{array}$ & $\begin{array}{l}0 \\
4.28 \\
4.28 \\
0 \\
0 \\
0 \\
0\end{array}$ & $\begin{array}{l}2.48 \\
8.38 \\
8.38 \\
0 \\
0 \\
0 \\
0\end{array}$ \\
\hline $\begin{array}{l}\text { Day 0 "filtered" } \\
408 \text { dilution }\end{array}$ & 7.48 & 0 & 0 & 4.28 & 33.38 \\
\hline $\begin{array}{l}408 \text { dilution } \\
\text { prepared from } \\
5 \text { day stock } \\
\text { solution }\end{array}$ & 6.61 & 0 & 0 & 20.88 & 75.08 \\
\hline 708 & 5.06 & 58.38 & 100.08 & 100.08 & 100.08 \\
\hline $\begin{array}{l}508 \\
408 \\
30 \% \\
208 \\
10 \% \\
58 \\
\text { Control }\end{array}$ & $\begin{array}{l}7.05 \\
7.49 \\
7.98 \\
8.19 \\
8.34 \\
8.43 \\
8.31\end{array}$ & $\begin{array}{l}0 \\
0 \\
0 \\
0 \\
0 \\
0 \\
0\end{array}$ & $\begin{array}{l}0 \\
0 \\
0 \\
0 \\
0 \\
0 \\
0\end{array}$ & $\begin{array}{l}0 \\
4.28 \\
0 \\
0 \\
0 \\
0 \\
0\end{array}$ & $\begin{array}{l}0 \\
4.28 \\
0 \\
0 \\
0 \\
0 \\
0\end{array}$ \\
\hline $\begin{array}{l}40 \% \text { prepared from } \\
25 \text { day stock } \\
\text { solutior }\end{array}$ & 6.57 & 0 & 0 & 70.88 & $70.8 \%$ \\
\hline
\end{tabular}

Measured in the exposure beakers. 
TABLE 25. COMPARISON OF MORTALITY OF DAPHNIA MAGNA IN NEUTRALIZATION

TESTS WITH FOUR TYPES OF DILUTION WATERS ${ }^{\text {a }}$

\begin{tabular}{|c|c|c|c|c|}
\hline \multirow[b]{2}{*}{ Condition } & \multicolumn{2}{|c|}{$R P-B R$} & \multicolumn{2}{|c|}{$W P-F$} \\
\hline & Neutralized & Non-Neutralized & Neutralized & Non-Neutralized \\
\hline & ------ & -...-Soft & Water--... & $-\ldots \ldots$ \\
\hline $\begin{array}{l}\text { Mortality }(\%) \\
\mathrm{pH} \\
\text { Total P (mg/L) }\end{array}$ & $\begin{array}{c}100 \\
7.25 \\
71.3\end{array}$ & $\begin{array}{c}100 \\
2.92 \\
69.9\end{array}$ & $\begin{array}{l}88 \\
7.69 \\
68.1\end{array}$ & $\begin{array}{c}100 \\
4.71 \\
19.9\end{array}$ \\
\hline $\begin{array}{l}\text { Mortality }(\%) \\
\text { pH } \\
\text { Total P (mg/L) }\end{array}$ & $\begin{array}{l}0 \\
7.19 \\
14.3\end{array}$ & $\begin{array}{l}0 \\
5.73 \\
14.0\end{array}$ & $\begin{array}{c}0 \\
7.48 \\
47.7\end{array}$ & $\begin{array}{l}0 \\
6.71 \\
6.63\end{array}$ \\
\hline $\begin{array}{l}\text { Mortality }(\%) \\
\mathrm{pH} \\
\text { Total P (mg/L) }\end{array}$ & $\begin{array}{l}0 \\
7.96 \\
69.1\end{array}$ & $\begin{array}{c}100 \\
4.70 \\
69.1\end{array}$ & $\begin{array}{l}40 \\
7.97 \\
89.4\end{array}$ & $\begin{array}{c}100 \\
3.91 \\
53.2\end{array}$ \\
\hline $\begin{array}{l}\text { Mortality }(\mathscr{w}) \\
\mathrm{pH} \\
\text { Total P }(\mathrm{mg} / \mathrm{L})\end{array}$ & $\begin{array}{l}-- \\
--\end{array}$ & $\begin{array}{l}0 \\
6.29 \\
48.4\end{array}$ & $\begin{array}{l}5 \\
7.98 \\
71.7\end{array}$ & $\begin{array}{l}10 \\
5.99 \\
35.4\end{array}$ \\
\hline $\begin{array}{l}\text { Mortality }(\%) \\
\text { pH } \\
\text { Total P (mg/L) }\end{array}$ & $\begin{array}{l}0^{b} \\
7.43 \\
93.1\end{array}$ & $\begin{array}{r}91.7^{\mathrm{b}} \\
5.47 \\
65.2^{2}\end{array}$ & $\begin{array}{l}4.2 \\
7.78 \\
66.4\end{array}$ & $\begin{array}{l}100 \\
5.38 \\
66.4\end{array}$ \\
\hline $\begin{array}{l}\text { Mortality }(\%) \\
\mathrm{pH} \\
\text { Total P }(\mathrm{mg} / \mathrm{L})\end{array}$ & $\begin{array}{l}-- \\
--\end{array}$ & $\begin{array}{l}0 \\
6.82 \\
46.6\end{array}$ & $\begin{array}{c}\mathrm{D} \\
7.81 \\
46.5\end{array}$ & $\begin{array}{l}0 \\
6.67 \\
46.8\end{array}$ \\
\hline $\begin{array}{l}\text { Mortality }(\%) \\
\mathrm{pH} \\
\text { Total P }(\mathrm{mg} / \mathrm{L})\end{array}$ & $\begin{array}{c}0 \\
7.80 \\
95.2\end{array}$ & $\begin{array}{c}0 \\
7.13 \\
96.3\end{array}$ & $\begin{array}{c}\text { d water-- } \\
30 \\
8.08 \\
125\end{array}$ & $125^{4} .99$ \\
\hline $\begin{array}{l}\text { Mortality }(\%) \\
\mathrm{pH} \\
\text { Total P (ng/L) }\end{array}$ & $\begin{array}{l}-- \\
-- \\
--\end{array}$ & $\begin{array}{l}-- \\
-- \\
--\end{array}$ & $\begin{array}{l}10 \\
8.31 \\
87.6\end{array}$ & $\begin{array}{l}0 \\
6.55 \\
87.5\end{array}$ \\
\hline
\end{tabular}

anly the treatments with the highest observed mortality are compared with the next lowest concentration. Mortality measurements were taken at $48 \mathrm{hr}$. (See Appendix C for complete data sets.)

Test 2 (Burn RP-16).

CNominal concentration at time test was started, analys is of sample after $8 \mathrm{hr}$ of agings was $96.4 \mathrm{mg} / \mathrm{L}$, Burn WP-7. 
However, the toxicity of neutralized and non-neutralized RP-BR solutions in soft water appeared to be identical in terms of total $P$. The toxic component(s) of the stock solutions were not identified, but it is apparent that a considerable amount of smoke is necessary to induce non-pH related mortality in a body of water irrespective of the buffering capacity of that water. Median lethal concentration ( $L C 50)$ values were not calculated for these data sets because they generaliy lacked treatments with partial mortality. Mortality between 48 and $96 \mathrm{hr}$ represents interactions with precipitated material.

\section{Phase II Tests}

It is readily apparent from the Phase I tests with $D$. magna that the primary mode of toxicity of phosphorus based smokes was acidification. The dilution water used for Phase II testing was Columbia River water. The carbonate buffering capacity of river water seasonally ranges from 55 to $65 \mathrm{mg} / \mathrm{L}$ as $\mathrm{CaCO}_{3}$. The results of acute toxicity tests for fish and invertebrates conducted during Phase II are reported as a function of $\mathrm{pH}$ and total phosphorus. The response of $S$. capricornutum to smoke-dcsed algal media was evaluated from a toxicological perspective and from the ability of phosphorus combustion products to stimulate algal growth.

S. capricornutum Toxicity Tests. The analysis of variance (ANOVA) of cell count data indicated significant differences for treatment means, time and interactions in the algal toxicity test with RP-BR (Table 26). The only significant differences in treatment means were observed at $96 \mathrm{hr}$. Cell count data for all sample periods are summarized in Appendix $A$. The $5 \%$ exposure solution was significantiy different $(p \sim 0.05$ ) compared with all other treatments at $96 \mathrm{hr}$ (Tables 27 and 28). The overall trends in this test suggest stimulation of algal growth at 1 and $4.6 \mathrm{mg} / \mathrm{L}$ total $P$ with the

TABLE 26. ANALYSIS OF VARIANCE (ANOVA) OF MEAN CELL COUNT DATA FROM THE ALGAL TOXICITY TEST WITH RP-BR

\begin{tabular}{|c|c|c|c|c|c|}
\hline Source & Sum of Squares & $\begin{array}{c}\text { Degrees of } \\
\text { Freedom }\end{array}$ & Mean Square & $F$ & $\begin{array}{l}\text { Tail } \\
\text { Prob. }\end{array}$ \\
\hline $\begin{array}{l}\text { Mean } \\
\text { Cell Counts } \\
\text { Error }\end{array}$ & $\begin{array}{r}2228910.87184 \\
6463387.15352 \\
614382.05409\end{array}$ & $\begin{array}{r}1 \\
7 \\
16\end{array}$ & $\begin{array}{r}2228910.87184 \\
923341.02193 \\
38398.87838\end{array}$ & $\begin{array}{l}58.05 \\
24.05\end{array}$ & $\begin{array}{l}0.0000 \\
0.0000\end{array}$ \\
\hline $\begin{array}{l}\text { Time } \\
\text { Interaction } \\
\text { Error }\end{array}$ & $\begin{array}{r}4886365.97658 \\
21736491.33644 \\
2013335.02675\end{array}$ & $\begin{array}{r}4 \\
28 \\
64\end{array}$ & $\begin{array}{r}1221591.49414 \\
776303.26202 \\
31458.35979\end{array}$ & $\begin{array}{l}38.83 \\
24.68\end{array}$ & $\begin{array}{l}0.0000 \\
0.0000\end{array}$ \\
\hline
\end{tabular}


TABLE 27. F-VALUES FOR COMPARISONS BETWEEN ALL POSSIBLE PAIRS OF MEANS AT 0, 24, 48, 72, AND 96 HOURS FOR RP-BR TOXICITY TEST WITH S. CAPRICORNUTUM

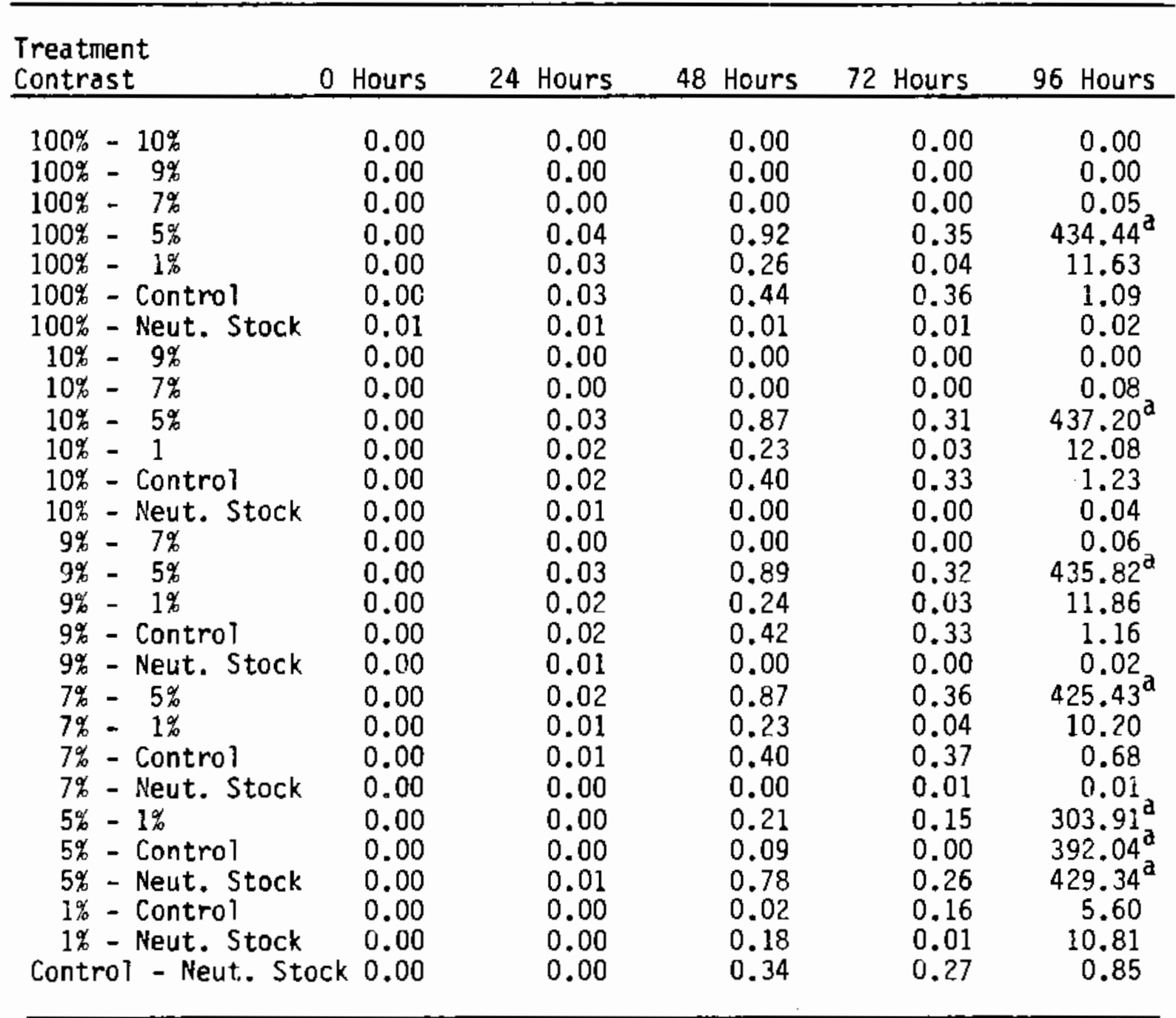

a Significant of $p^{<} .05$ using Scheffé's test with error rate adjustment for simul taneous comparisons.

toxic effects of acidification inhibiting growth at $\mathrm{pH}$ levels $\sim 5.0$. Growth in the excessively buffered stock solution from burn RP-7 was inhibited to the same degree as the acidified stock solution suggesting that unidentified components of the stock solution were toxic independent of $\mathrm{pH}$. 
TABLE 28. RESPONSE OF SELENASTRUM CAPRICORNUTUM TO RP-BR SMOKE-DOSED WATER (96-HR DATA)

\begin{tabular}{|c|c|c|c|}
\hline Treatment $(\%)$ & Total P (mg/L) & $\mathrm{pH}$ & $\begin{array}{l}\text { Mean }( \pm 1.0 \text { S.D.) } \\
\text { Cell Counts in } L \times 10^{6}\end{array}$ \\
\hline $\begin{array}{r}100 \\
10 \\
9 \\
7 \\
5 \\
1 \\
\text { Control } b \\
100^{b}\end{array}$ & $\begin{array}{c}97 \\
9.3 \\
8.6 \\
6.1 \\
4.6 \\
1.0 \\
(<\mathrm{DL})^{\mathrm{C}} \\
75\end{array}$ & $\begin{array}{l}2.72^{\mathrm{a}} \\
5.03^{\mathrm{a}} \\
4.95^{\mathrm{a}} \\
5.70^{\mathrm{a}} \\
7.04^{\mathrm{a}} \\
7.76^{\mathrm{a}} \\
7.8 \mathrm{a} \\
7.9\end{array}$ & $\begin{array}{l}0.03 \pm 0.02 \\
0.02 \pm 0.00 \\
0.02 \pm 0.02 \\
0.06 \pm 0.07 \\
3.36 \pm 0.80 \\
0.57 \pm 0.80 \\
0.20 \pm 0.12 \\
0.05 \pm 0.01\end{array}$ \\
\hline $\begin{array}{l}\text { a Measured at } \\
\text { b Neutraljzed } \\
\text { c Below detect } \\
\text { d Signifjcant }\end{array}$ & $\begin{array}{l}\text { of test (RP-8 } \\
\text { ck solution wi } \\
\text { limit. } \\
p \leq 0.05\end{array}$ & $360 \mathrm{mon}$ & otal alka \\
\hline
\end{tabular}

The response of $S$. capricornutum to WP-F smoke-dosed algae media was simiiar to that of $R P-B R$ except that the responses within treatments were more variable. The high level of variability may be related to the size of the inoculum at the start of the test. The ANOVA showed no significant differences in treatment means, time or interactions (Table 29) and no additional statistical tests were done. Trends in the 96-hr data (Table 30) suggest that inhibition of growth was occurring at $\mathrm{pH}$ Tevels of $\sim 6.0$; however, the high level of variability prevents any conclusive statements regarding growth stimulation.

S. capricornutum Growth Stimulation Tests. The analysis of RP-BR and WP-F algal stimulation tests were based on mean cell counts determined with a Coulter counter. Chlorophyll analyses were also performed, but the data were more variable than the Coulter counter data and were not analyzed (Apperıdix A). It has been summarized in the tables for comparison with the coulter counter data only.

Algal stimulation tests were performed with neutralized and nonneutralized solutions of smoke-dosed algal media with RP-BR and WP-F. Cell count data for all sample periods are summarized in Appendix $A$. The repeated measures ANOVA for the RP-BR test (Table 31) indicated significant main effects, i.e., pH (neutralized vs. non-neutralized exposure solutions), tota? phosphorus concentrations and time, and all possible interactions. 
TABLE 29. ANALYSIS OF VARIANCE (ANOVA) OF MEAN CELL CQUNT DATA FRON! THE ALGAL TOXICITY TEST WITH WP-F

\begin{tabular}{lrrrrr}
\hline Source & Sum of Squares & $\begin{array}{c}\text { Degrees of } \\
\text { Freedom }\end{array}$ & Mean Square & F & $\begin{array}{r}\text { Tail } \\
\text { Prob. }\end{array}$ \\
\hline Mean & 576622.29515 & 1 & 576622.29515 & 11.25 & 0.0047 \\
Cell Counts & 337156.74826 & 6 & 56192.79138 & 1.10 & 0.4113 \\
Error & 717357.50717 & 14 & 51239.82194 & & \\
& & & & & \\
Time & 1004987.04523 & 4 & 251246.76131 & 7.90 & 0.0000 \\
Interaction & 849333.35094 & 24 & 35388.88962 & 1.11 & 0.3604 \\
Error & 1780065.71975 & 56 & 31786.88785 & & \\
\hline
\end{tabular}

TABLE 30. RESPONSE OF SELENASTRUM CAPRICORNUTUM TO WP-F SMOKE-DOSED W'ATER (96-HR DATA)

\begin{tabular}{cccc}
\hline & & & Mean $\left( \pm 1.0 \mathrm{~S}_{\mathrm{a}} \mathrm{D}.\right)$ \\
Treatment $(\%)$ & Total $\mathrm{P}$ & $\mathrm{pH}$ & Cell Counts \\
\hline 100 & 12.5 & 2.55 & $0.02 \pm 0.02$ \\
6 & 7.6 & 6.06 & $0.05 \pm 0.04$ \\
3 & 3.6 & 6.26 & $0.66 \pm 0.55$ \\
1 & 1.8 & 6.77 & $0.43 \pm 0.48$ \\
0.6 & $0.7 \mathrm{~b}$ & 7.02 & $0.26 \pm 0.42$ \\
Control & $<0 \mathrm{~L}$ & 7.44 & $0.42 \pm 0.68$ \\
Neut. Stock & 12.5 & 7.32 & $0.02 \pm 0.00$ \\
\hline a All counts $\times 10^{6} / \mathrm{mL}$ & & \\
b Bl cow detection 1imit. & &
\end{tabular}


TABLE 31. ANALYSIS OF VARIANCE ANOVA OF ALGAL STIMULATION TESTS WITH RP-BR (BASED ON 96-HR MIEAN CELL COUNTS)

\begin{tabular}{|c|c|c|c|c|c|}
\hline Source & & Degrees of & Yean Soulare & $F$ & Tail \\
\hline Mean & 16986771.88991 & 1 & 16986771.88991 & 1444.76 & 0.0000 \\
\hline Phosphorus Level & 1320084.16965 & 4 & 330021.04241 & 28.07 & 0.0000 \\
\hline Neutralization & 765093.50002 & 1 & 765093.50002 & 65.07 & 0.0000 \\
\hline $\begin{array}{l}\text { Phosphorus vs. } \\
\text { Neutralization/ } \\
\text { Non-neutralization }\end{array}$ & 1201015.29635 & 4 & 300253.82409 & 25.54 & 0.0000 \\
\hline Error & 329209.04702 & 28 & $\uparrow 1757.46596$ & & \\
\hline \multicolumn{6}{|l|}{ Interactions } \\
\hline Time & 24018794.18772 & 4 & 6004698.54693 & 921.76 & 0.0000 \\
\hline Time vs. Phosphorus & 3333319.42322 & 16 & 208332.46395 & 31.98 & 0.0000 \\
\hline Time vs. Neutrabiation & 1269295.64087 & 4 & 317323.91022 & 48.71 & 0.0000 \\
\hline $\begin{array}{l}\text { Time } \times \text { Phosphorus } \\
\times \text { Neutralization }\end{array}$ & 2297734.17342 & 16 & 143608.38584 & 22.04 & 0.0000 \\
\hline Error & 729613.07148 & 112 & 6514.40242 & & \\
\hline
\end{tabular}

There were no significant differences in mean cell counts until $96 \mathrm{hr}$ (Table 32). At that time, the response of the neutralized treatments ( $\mathrm{pH} 7.15$ to 7.25 ) were significantly different ( $\alpha=0.05$ with Scheffe's correction) than the acidified $5.0 \%(\mathrm{pH} 4.8$ ) and the $3.3 \%$ (pH 5.5) solutions (Tables 32 and 33). The difference in growth indicated inhibition due to acidification of the medium further suggesting that acidification was the primary mode of toxicity. A trend toward higher levels of growth as a function of increasing $P$ concentration was noted. There were no differences at any time in response within the neutralized treatments. In the non-neutralized treatments, however, the $96-\mathrm{hr}$ mean cell count in the $4.98 \%$ solution was significantly different than the three more diluted treatments and the $3.27 \%$ solution was significantly different than the $2.77 \%$ and the $1.81 \%$ solutions. Moreover, mean cell counts in the $\mathrm{PO}_{4}^{3-}$ deficient media were significantly lower (using Scheffé's corrections) than all four neutralized treatments and the $2.77 \%$ and $1.81 \%$ non-neutralized treatments. Mean cell counts in the EPA media control treatment were twice that of the $\mathrm{PO}_{4}^{3-}$ deficient control. 
TABLE 32. F-VALUES FOR COMPARISONS BETWEEN ALL POSSIBLE PAIRS OF MEANS AT 0, 24, 48, 72 , AND 96 HOURS FOR RP-8R ALGAL STIMULATION TESTS

\begin{tabular}{|c|c|c|c|c|c|}
\hline $\begin{array}{r}\text { Treatment } \\
\text { Contrast }\end{array}$ & 0 Hours & 24 Hours & 48 Hours & 72 Hours & 96 Hours \\
\hline 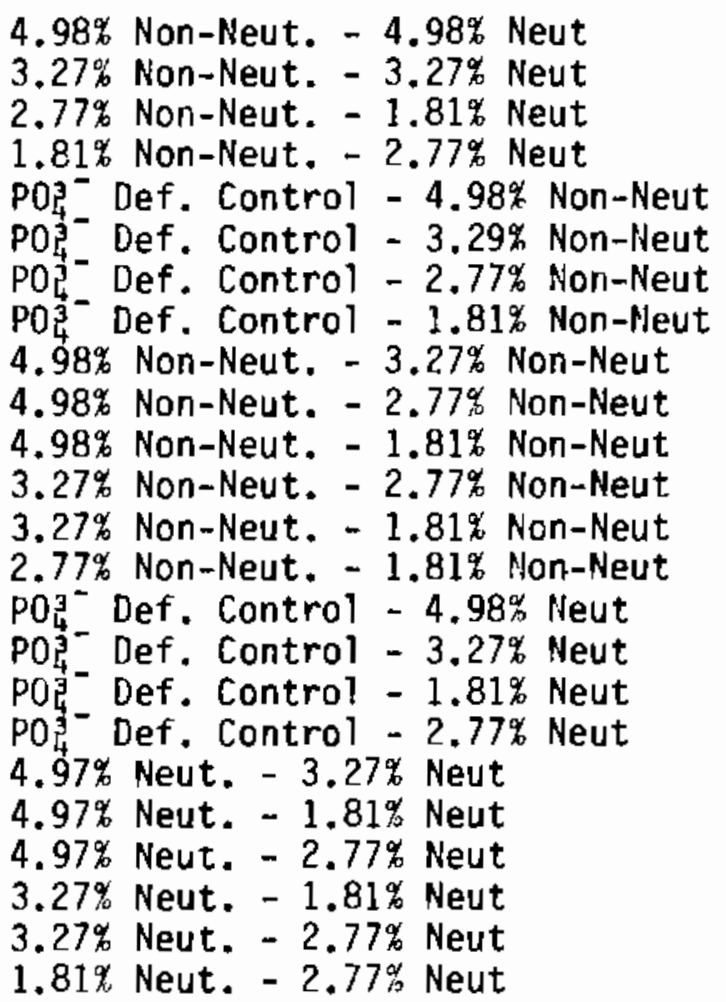 & $\begin{array}{l}0.04 \\
0.00 \\
0.01 \\
0.01 \\
0.01 \\
0.01 \\
0.00 \\
0.00 \\
0.00 \\
0.03 \\
0.02 \\
0.02 \\
0.01 \\
0.00 \\
0.09 \\
0.01 \\
0.00 \\
0.01 \\
0.05 \\
0.07 \\
0.05 \\
0.00 \\
0.00 \\
0.00\end{array}$ & $\begin{array}{l}0.20 \\
0.00 \\
0.19 \\
0.02 \\
0.06 \\
0.00 \\
0.06 \\
0.00 \\
0.10 \\
0.00 \\
0.06 \\
0.09 \\
0.00 \\
0.05 \\
0.06 \\
0.01 \\
0.04 \\
0.02 \\
0.03 \\
0.01 \\
0.01 \\
0.01 \\
0.00 \\
0.00\end{array}$ & $\begin{array}{l}3.32 \\
1.60 \\
0.10 \\
0.04 \\
1.66 \\
0.00 \\
0.97 \\
0.17 \\
1.76 \\
5.18 \\
2.90 \\
0.90 \\
0.14 \\
0.33 \\
0.59 \\
1.70 \\
0.45 \\
0.38 \\
0.09 \\
0.05 \\
0.07 \\
0.40 \\
0.47 \\
0.00\end{array}$ & $\begin{array}{r}33.19 \\
12.86 \\
0.01 \\
0.40 \\
24.05 \\
1.07 \\
2.43 \\
2.99 \\
14.97 \\
41.75 \\
44.00 \\
6.72 \\
7.64 \\
0.03 \\
3.09 \\
6.51 \\
2.11 \\
5.59 \\
0.11 \\
0.33 \\
0.03 \\
1.21 \\
0.03 \\
0.83\end{array}$ & $\begin{array}{r}422.33^{\mathrm{a}} \\
173.31^{\mathrm{a}} \\
0.11 \\
4.14 \\
52.93 \\
9.05 \\
159.40^{\mathrm{a}} \\
273.67^{\mathrm{a}} \\
105.74^{\mathrm{a}} \\
396.03^{\mathrm{a}} \\
567.31^{\mathrm{a}} \\
92.50 \\
183.20^{\mathrm{a}} \\
15.35 \\
213.47^{\mathrm{a}} \\
261.55^{\mathrm{a}} \\
167.85^{\mathrm{a}} \\
210.47^{\mathrm{a}} \\
1.98 \\
16.26 \\
7.65 \\
10.35 \\
2.77 \\
2.41\end{array}$ \\
\hline
\end{tabular}

a Significant at p<.05 using Scheffe's test with error rate adjustment for simultaneous comparisons. 
TABLE 33. RESPONSE OF SELENASTRUM CAPRICORNUTUN IN ALGAL STIMULATION TESTS WITH RP-BR SMOKE-DOSED P0 3 DEFICIENT MEDIA (96-HR DATA)

\begin{tabular}{|c|c|c|c|c|c|c|c|}
\hline \multirow[b]{2}{*}{$\begin{array}{l}\text { Treatment } \\
\text { (o Stock } \\
\text { Solution) }\end{array}$} & \multirow[b]{2}{*}{$\begin{array}{l}\text { Nominal } \\
\text { Total P } \\
\text { (mg/L) }\end{array}$} & \multirow[b]{2}{*}{$\begin{array}{c}\mathrm{POA}^{-} \\
(\mathrm{mg} / \mathrm{L})\end{array}$} & \multirow[b]{2}{*}{$\begin{array}{c}\text { Inftial } \\
\mathrm{pH}\end{array}$} & \multicolumn{3}{|c|}{ Ratio } & \multirow{2}{*}{$\begin{array}{c}\text { Ratio } \\
\text { Chlorophyll } \\
\text { to P0 } 4 \\
\text { Deficient } \\
\text { Controls } \\
\end{array}$} \\
\hline & & & & $\begin{array}{c}\text { Mean } \\
( \pm 1.0 \text { S.D.) } \\
\text { Ceit Counts } \\
\left(\times 10^{6} / \mathrm{mL}\right)\end{array}$ & $\begin{array}{l}\text { Cell Counts } \\
\text { to } \mathrm{PO}_{4}^{-} \\
\text {Deficient } \\
\text { Controls }\end{array}$ & $\begin{array}{c}\text { Mean } \\
( \pm 1.0 \text { S.D. }) \\
\text { Chlorophyll A } \\
(\mathrm{mg} / \mathrm{L})\end{array}$ & \\
\hline $4.98 \%$ & 5.13 & 1.41 & 4.95 & $0.01 \pm 0.00$ & 0.02 & $0.70 \neq 0.20$ & 0.02 \\
\hline 3.278 & 3.37 & 1.13 & 5.2 & $0.65 \pm 0.25$ & 1.41 & $54.68 \pm 39.68$ & 1.72 \\
\hline $2.77 \%$ & 2.85 & 0.86 & 6.08 & $1.24 \pm 0.15$ & 2.70 & $189.95 \pm 33.47$ & 5.94 \\
\hline 1.818 & 1.91 & 0.61 & 6.48 & $1.48 \pm 0.13$ & 3.22 & $123.12 \pm 35.81$ & 3.85 \\
\hline 4.988 & 5.13 & 1.38 & 7.20 & $1.59 \pm 0.16$ & 3.46 & $187.31 \pm 128,20$ & 5.86 \\
\hline 3.278 & 3.37 & 0.92 & 7.15 & $1.45 \pm 0.08$ & 3.15 & $281.01 \pm 97.05$ & 8.79 \\
\hline 2.778 & 2.85 & 0.83 & 7.24 & $1.26 \pm 0.20$ & 2.74 & $118.40 \pm 50.92$ & 3.70 \\
\hline 1.818 & 1.91 & 0.64 & 7.25 & $1.35 \pm 0.09$ & 2.93 & $182.51 \pm 49.80$ & 5.71 \\
\hline \multicolumn{8}{|l|}{$\mathrm{PO}_{4}^{-}$} \\
\hline \multicolumn{8}{|l|}{ Deficient } \\
\hline Media & 0.15 & 0.25 & 7.46 & $0.46 \pm 0.17$ & -- & $31.97 \pm 38.31$ & -- \\
\hline \multicolumn{8}{|l|}{ Complete } \\
\hline Media & $=$ & 0.69 & 7.50 & $0.83 \pm 0.21$ & 1.81 & $32.32 \pm 27.38$ & 1.01 \\
\hline
\end{tabular}

The responses observed in the WP-F algal stimulation test were generally similar to those in the RP-BR test. All main and interaction effects were significant $(a=0.5$, Table 34$)$. At 72 and $96 \mathrm{hr}$, the individual means test showed that the non-neutralized $10 \%$ treatment was significantly different ( $\alpha=0.05$ with Scheffe's correction) than the $5.2 \%$ and $2.4 \%$ treatments (Tables 35 and 36 ). There was no significant difference in the response of the neutralized treatments or the non-neutralized treatments and the $\mathrm{PO}_{4}^{3-}$ deficient control treatment. Growth in the $\mathrm{PO}_{4}^{3-}$ deficient media was approximately $50 \%$ of the growth observed in the complete media control. 
TABLE 34. ANALYSIS OF VARIANCE (ANOVA) OF STIMULATION TESTS WITH WP-F

\begin{tabular}{|c|c|c|c|c|c|}
\hline Source & Sum of Squares & $\begin{array}{l}\text { Oegrees of } \\
\text { Freedom }\end{array}$ & Mean Square & $\underline{F}$ & $\begin{array}{l}\text { Tail } \\
\text { Prob. }\end{array}$ \\
\hline $\begin{array}{l}\text { Mean } \\
\text { Phosphorus Level } \\
\text { Neutralization } \\
\text { Phosphorus vs. } \\
\text { Neutralization/ } \\
\text { Non-neutralization }\end{array}$ & $\begin{array}{r}5193112.52596 \\
76029.27979 \\
83027.44604 \\
561676.41932\end{array}$ & $\begin{array}{l}1 \\
4 \\
1 \\
4\end{array}$ & $\begin{array}{r}5193112.52596 \\
192257.31995 \\
83027.44604 \\
140419.10483\end{array}$ & $\begin{array}{r}506.00 \\
18.73 \\
8.09 \\
13.68\end{array}$ & $\begin{array}{l}0.0000 \\
0.0000 \\
0.0079 \\
0.0000\end{array}$ \\
\hline Error & 307889.54923 & 30 & 10262.98497 & & \\
\hline $\begin{array}{l}\text { Interactions } \\
\text { Time } \\
\text { Time vs. Phosphorus } \\
\text { Time vs. Neutralization } \\
\text { Time x Phosphorus } \\
\quad \times \text { Neutralization } \\
\text { Error }\end{array}$ & $\begin{array}{r}3807459.66365 \\
1081407.70097 \\
120239.50460 \\
1075014.35844 \\
1072640.32895\end{array}$ & $\begin{array}{r}4 \\
16 \\
4 \\
16\end{array}$ & $\begin{array}{r}951864.91591 \\
67587.98131 \\
30059.87615 \\
67188.39740\end{array}$ & $\begin{array}{r}106.49 \\
7.56 \\
3.36 \\
7.52\end{array}$ & $\begin{array}{l}0.0000 \\
0.0000 \\
0.0120 \\
0.0000\end{array}$ \\
\hline
\end{tabular}


TABLE 35. F-VALUES FOR COMPARISONS BETWEEN ALL POSSI8LE PAIRS OF MEANS AT 0, 24, 48, 72 , AND 96 HOURS FOR WP-F ALGAL STIMULATION TESTS

\begin{tabular}{|c|c|c|c|c|c|}
\hline $\begin{array}{l}\text { Treatment } \\
\text { Contrast }\end{array}$ & 0 Hours & 24 Hours & 48 Hours & 72 Hours & 96 Hours \\
\hline 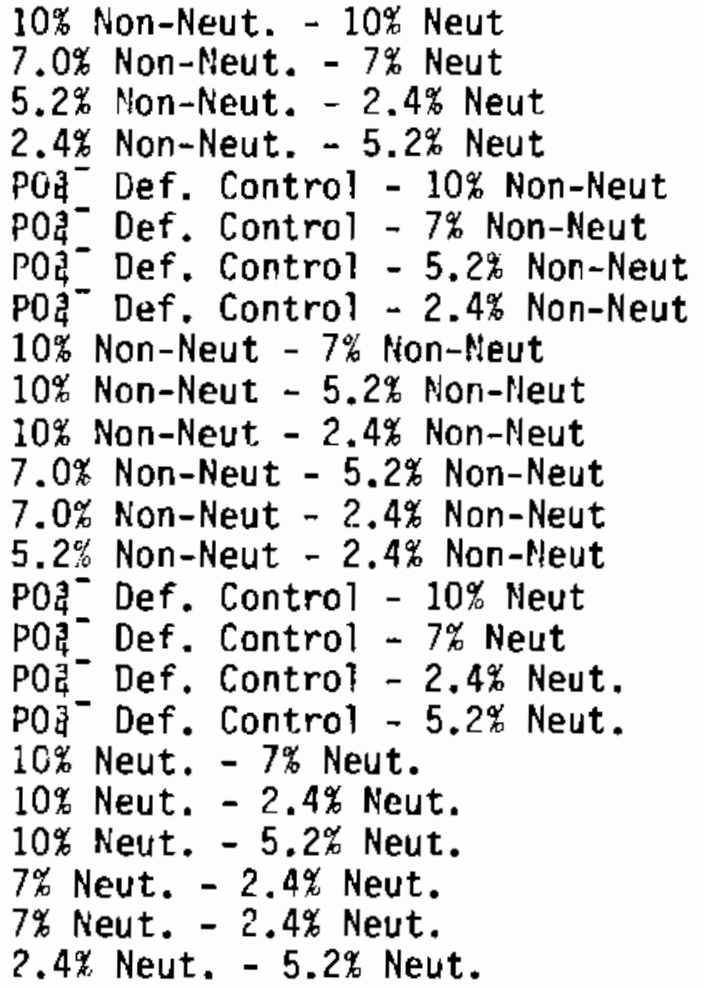 & $\begin{array}{l}0.00 \\
0.00 \\
0.00 \\
0.00 \\
0.00 \\
0.01 \\
0.00 \\
0.01 \\
0.00 \\
0.00 \\
0.01 \\
0.00 \\
0.00 \\
0.01 \\
0.00 \\
0.00 \\
0.00 \\
0.00 \\
0.00 \\
0.00 \\
0.00 \\
0.00 \\
0.00 \\
0.00\end{array}$ & $\begin{array}{l}0.00 \\
0.17 \\
0.02 \\
0.00 \\
0.62 \\
0.61 \\
0.36 \\
0.31 \\
0.00 \\
0.03 \\
0.05 \\
0.03 \\
0.05 \\
0.00 \\
0.56 \\
0.13 \\
0.23 \\
0.27 \\
0.15 \\
0.07 \\
0.05 \\
0.01 \\
0.02 \\
0.00\end{array}$ & $\begin{array}{l}1.73 \\
0.74 \\
0.60 \\
0.02 \\
2.43 \\
1.94 \\
0.55 \\
0.08 \\
0.03 \\
0.66 \\
1.62 \\
0.42 \\
1.22 \\
0.21 \\
0.06 \\
0.29 \\
0.00 \\
0.20 \\
0.09 \\
0.08 \\
0.04 \\
0.32 \\
0.01 \\
0.23\end{array}$ & $\begin{array}{r}20.42 \\
22.50 \\
26.97 \\
20.06 \\
9.26 \\
8.23 \\
0.24 \\
54.62 \\
0.03 \\
6.51 \\
108.85^{\mathrm{a}} \\
5.65 \\
105.24^{\mathrm{a}} \\
62.13 \\
2.18 \\
3.52 \\
22.11 \\
8.48 \\
0.16 \\
10.40 \\
2.06 \\
7.99 \\
1.07 \\
3.21\end{array}$ & $\begin{array}{r}59.69 \\
7.72 \\
18.83 \\
20.43 \\
20.99 \\
19.52 \\
10.79 \\
35.85 \\
0.03 \\
61.86 \\
111.69^{\mathrm{a}} \\
59.33 \\
108.28^{\mathrm{a}} \\
7.31 \\
9.89 \\
2.69 \\
1.11 \\
2.15 \\
22.90 \\
17.64 \\
2.81 \\
0.34 \\
9.66 \\
6.36\end{array}$ \\
\hline
\end{tabular}

\footnotetext{
a Significant at p<.05 using Scheffe's test with error rate adjustment for simultaneous comparisons.
} 
TABLE 36. RESPONSE OF SELENASTRUM CAPRICORNUTIM IN ALGAL STIMULATION TESTS WITH WP-F SMOKE-DOSED PO ${ }_{4}^{3}$-DEFICIENT MEDIA (96-HR DATA)

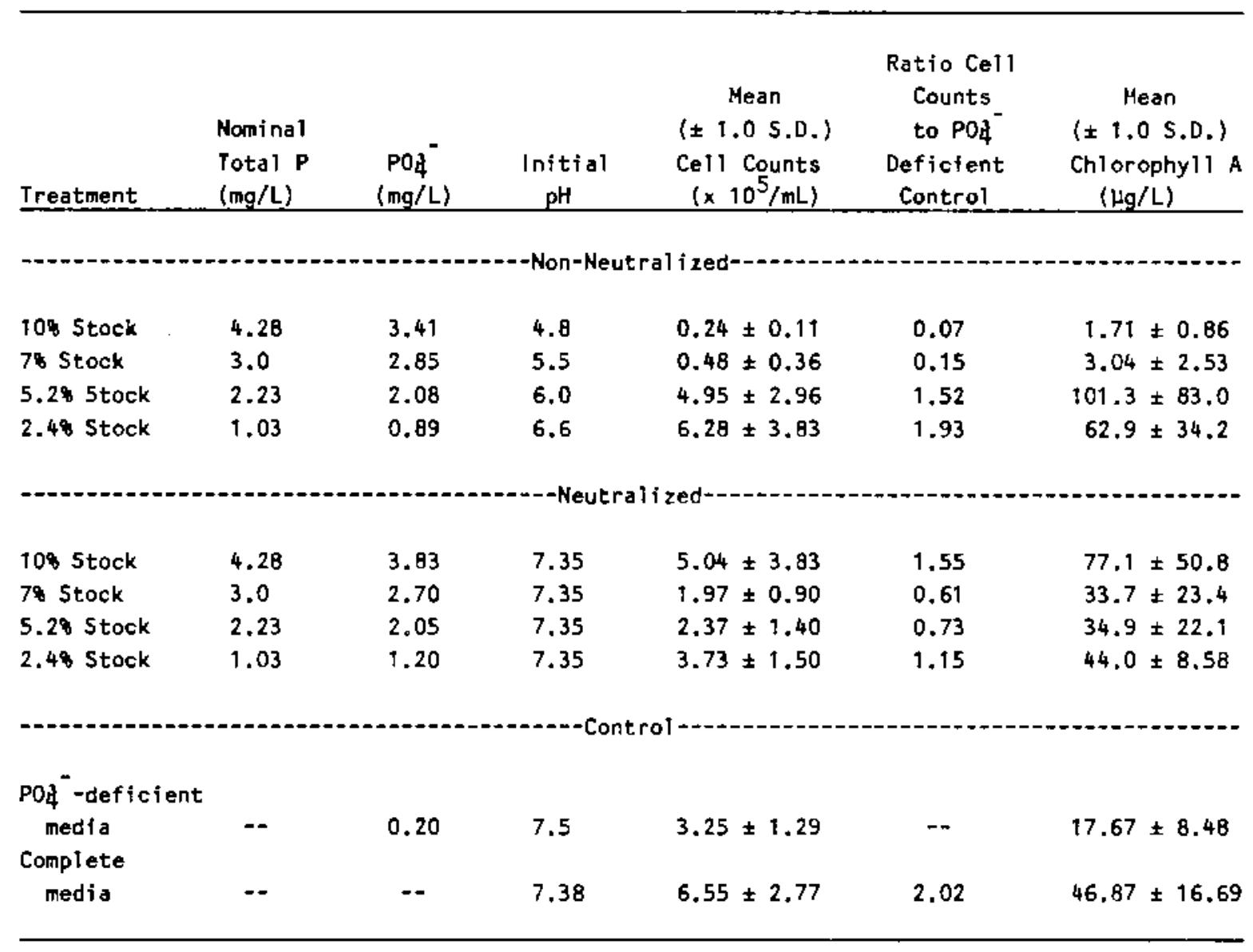

One difference in the two algal stimulation tests was that the neutralized solutions showed greater growth than the phosphate deficient controls in the RP-BR test, but not in the WP-F test. This discrepancy may be related to the fact that $\mathrm{PO}_{4}^{3-}$ levels in the WP-F tests were saturating while $\mathrm{PO}_{4}^{3-}$ levels in the RP-BR test were not.

Phase II Acute Toxicity Tests. The responses of fish and macroinvertebrates to smoke-dosed river water were summarized as LC50 values as a function of initial $\mathrm{pH}$ and total phosphorus. These results are summarized in Table 37 for RP-BR and WP-F tests. Additional monitoring data for toxicity tests is summarized in Appendix C. The relationship between LC50 values based on initial pH and total phosphorus are relatively consistent. In the WP-F tests, the LC50 value based on phosphorus for Hexagenia was 
TABLE 37. MEDIAN LETHAL CONCENTRATION (LC50) VALUES OF WP-F AND RP-BR ACUTE TOXICITY TESTS

\begin{tabular}{|c|c|c|c|c|c|}
\hline \multirow[b]{2}{*}{ Test Species } & \multirow[b]{2}{*}{ Test Duration } & \multicolumn{2}{|c|}{ Total Phosphorus $(\mu \mathrm{g} / \mathrm{mL})$} & \multicolumn{2}{|c|}{$\mathrm{pH}$} \\
\hline & & LC50 & $\begin{array}{c}\text { 950 Confidence } \\
\text { Interval }\end{array}$ & LC50 & $\begin{array}{c}\text { 95\% Confidence } \\
\text { Interval }\end{array}$ \\
\hline D. magna & $48 \mathrm{hr}$ & 29.20 & $(25.64-33.25)$ & 5.52 & $(5.28-5.77)$ \\
\hline ㅁ. & $48 \mathrm{hr}$ & 34.99 & $(33.77-36.27)$ & 4.36 & $(4.21-4.52)$ \\
\hline Hexagenia & $48 \mathrm{hr}$ & 44.08 & $(43.28-44.89)$ & 3.99 & $(3.92-4.06)$ \\
\hline $\begin{array}{l}\text { P. dissimulus } \\
\text { Fathead minnow }\end{array}$ & $48 \mathrm{hr}$ & 41.72 & $(40.26-43.24)$ & 3.68 & $(3.61-3.75)$ \\
\hline $\begin{array}{l}\text { P. promelas } \\
\text { RaInbow Trout }\end{array}$ & $96 \mathrm{hr}$ & 36.99 & $(35.87-38.15)$ & 4.45 & $(4.33-4.57)$ \\
\hline Br. gairdneri & $96 \mathrm{hr}$ & 33.22 & $(32.39-34.08)$ & 5.12 & $(5.04-5.20)$ \\
\hline$\underset{\text { Lh. machrochirus }}{\text { Channe? Catfish }}$ & $96 \mathrm{hr}$ & 43.76 & $(42.93-44.61)$ & 3.92 & $(3.86-3.98)$ \\
\hline 1. punctatus & $96 \mathrm{hr}$ & 41.59 & $\{39.63-43.65\}$ & 4.27 & $(4.06-4.50)$ \\
\hline D. magna & $48 \mathrm{hr}$ & 29.69 & $(29.10-30.28)$ & 5.40 & $(5.28-5.53)$ \\
\hline Hex. $\frac{\text { axteca }}{\text { Hexagenia }}$ & $\begin{array}{l}48 \mathrm{hr} \\
48 \mathrm{hr}\end{array}$ & $\begin{array}{l}31.44 \\
42.18\end{array}$ & $(29.93 a-33.02)$ & $\begin{array}{l}5.16 \\
4.02\end{array}$ & $(4.90-5.44)$ \\
\hline$\frac{\text { P. }}{\text { Fathead minnow }}$ & $48 \mathrm{hr}$ & 55.66 & $(52.46-59.06)$ & 3.43 & $(3.31-3.55)$ \\
\hline Rainbon trout & $96 \mathrm{hr}$ & 28.75 & $(27.91-29.61)$ & 5.50 & $(5.41-5.60)$ \\
\hline$\frac{5}{\text { sluegill sunfish }}$ & $96 \mathrm{hr}$ & 40.55 & $(39.13-42.03)$ & 4.41 & $(4.31-4.51)$ \\
\hline Lhannel Catfish & $96 \mathrm{hr}$ & 35.90 & $(33.83-38.11)$ & 3.97 & $(3.92-4.01)$ \\
\hline I. punctatus & $96 \mathrm{hr}$ & 45.05 & $(44.97-45.94)$ & 3.79 & $(3.72-3.85)$ \\
\hline
\end{tabular}

a No partial mortality, confidence intervals not calculated.

higher than $\mathrm{H}$. azteca, but was reversed for $\mathrm{pH}$. Similar contrasting relationship $\overline{5}$ were observed in the RP-BR tests among $S$. gairdneri, I. punctatus and $L$. macrochirus. These contrasts point to the variability associated with the degree of acidification imparted by the phosphorus smoke between burns. Because of this variability, no particular species of fish can be judged to be more sensitive than another nor can $R P+B R$ smoke be 
judged to be more toxic than WP-F smoke. The difference in LC50 values between WP-F and RP-BR for $\underline{S}$. gairdneri may be attributed to the fact that the fish tested with WP-F had just buttoned up and were probably more sensitive due to age differences.

Among the invertebrates, first instar D. magna were the most sensitive species. Although LC50 values were not determined during Phase I tests with $\underline{D}$. magna in well water, the mortality patterns at $48 \mathrm{hr}$ agree with the responses observed in river water. The LC50 values repeatedly fell between a $\mathrm{pH}$ of 5.0 and 6.0 . The midge larvae $\underline{\mathrm{P}}$. dissimulus was the most resilient species tested. Variation in the ranking of LC50 values may be attributed to inconsistencies in the relationship between $\mathrm{pH}$ and total phosphorus among burns.

\subsection{SGF NO. 2 FOG OIL}

Aromatic and saturated components of three batches of fog $0 i 1$ were analyzed by GC and only minor differences were observed in the chromatograms. The solubility of the oil in water was very low. The composition of aromatic components found in OW/M of vaporized and bulk fog oil was different than what would have been predicted from their relative abundances in the whole oil. Filtration removed most of the dispersed $0 i 1$ in the OWMs. Vaporization increased the number of free radicals, but did not increase the levels of phenolic compounds. Photolysis increased the number of water soluble constituents and radically changed the physical properties of vaporized and bulk fog oil.

Toxicity testing in Phase I and II indicated that the fog cii was relatively non-toxic before and after vaporization. The primary hazard is the potential for aquatic organisms to become fouled when oil adheres directly to body surfaces or is entrained during filter-feeding. Photolysis increased the toxicity of the 011 , presumably by increasing the aqueous solubility of the oil.

\subsubsection{Fog 0i1 Characterization (Phase I)}

The three batches of fog oit and 0WMs prepared with vaporized and bulk lots of $0 i 1$ were characterized in Phase I. No major differences were found in the aromatic and saturated hydrocarbon content of three batches of fog oil. $0 i 1$ water mixtures prepared with bulk and vaporized fog oil did not differ significantly. Infrared spectroscopy was selected as the method for monitoring total oil concentrations in fog oil-water mixtures. Saturated solutions of fog $0 i 1$ contained 190 to $350 \mu \mathrm{g} / \mathrm{L}$ total 011 , that was composed primarily of low molecular weight aromatic compounds. Filtration removed about half of the aromatic hydrocarbons from the OWM.

\section{BuTk Fog 0 il}

Aromatic and saturated hydrocarbon fractions of the three batches of fog oil were analyzed by high resolution capillary gas chromatography (GC). 
No differences in chromatographic patterns of aromatic hydrocarbons were apparent among these three batches of oil. The two fog oils designated Batch 2 and Batch 3 (most recent batches) contained significant amounts of what appeared to be the branched-chain saturated hydrocarbons, pristane and phytane. The saturated hydrocarbon chromatograms also showed the presence of a large number of unresolved components containing approximately 15 to 27 carbon atoms. Aromatic hydrocarbon chromatograms showed the presence of a great many unresolved components (Figure 8). Chromatograms of vaporized fog oil were indistinguishable from bulk fog oil chromatograms. Phenol content of the oils was very low.

\section{Bulk and Vaporized 0il-Water Mixtures}

In conjunction with the analysis of fog oils, we selected the oldest batch (Batch 1) and prepared oil water mixtures (OWM) of the oil and the vaporized oil (FO-1). This batch of fog $0 i 1$ was used because it may have been more oxidized than the other batches and, hence, may have contained more water soluble components. One hundred milliliters of Batch 2 fog oil was gently mixed (by slow stirring) with $9.9 \mathrm{~L}$ of well water for $4 \mathrm{hr}$ and allowed to stand for $1 \mathrm{hr}$. This mixing method has been used for other oils and synfuel materials at PNL and provides a source of comparison for SFG No. 2 fog oils. The oil-water mix was siphoned and used for chemical analysis and preliminary toxicity tests with $D$. magna. Both filtered $(0.45 \mu \mathrm{m}$ at 10 psi) and unfiltered fractions were tested and analyzed. Similariy, a slow mix was prepared with $67 \mathrm{~mL}$ of vaporized Batch 1 fog $0 i 1$ in $6.7 \mathrm{~L}$ of well water.

Infrared Analysis. Filtered and unfiltered 500-mL samples of the OWM were acidified, extracted with $\mathrm{CCl}_{4}$, and analyzed for total oil concentration on the day the OWM was prepared and on each of the following 2 days. Filtered and unfiltered well water blank samples were also analyzed on each of the 3 days. Total oil concentrations in the OWM are shown in Table 38. Infrared scans of $73.8 \mu \mathrm{g} / \mathrm{mL}$ and $14.7 \mu \mathrm{g} / \mathrm{mL}$ standard $\mathrm{CCl}_{4}$ solutions are shown in Figure 9, along with a $\mathrm{CCl}_{4}$ extract of filtered and unfiltered OWM.

Unfiltered well water blanks consistently showed no absorbence in the $\mathrm{C}-\mathrm{H}$ stretching frequency region. However, filtration of well water blanks introduced a contaminant into the water equivalent to about $140 \mu \mathrm{g} 011 / \mathrm{L}$ water (Figure 9). Concentrations of total 011 in the aqueous samples showed no significant change with time from day 0 through day 2.

Both aromatic and saturated hydrocarbon fractions in vaporized and bulk Batch 1 fog oil OWMs were analyzed by high resolution capillary gas chromatography (GC) using flame ionization detection (FID) after separation into saturated and aromatic fractions (Warner 1976). Concentrations of normal saturated hydrocarbons were extremely low in the water $(<1 \mu \mathrm{g} / \mathrm{L})$; no attempt was made to measure them. 


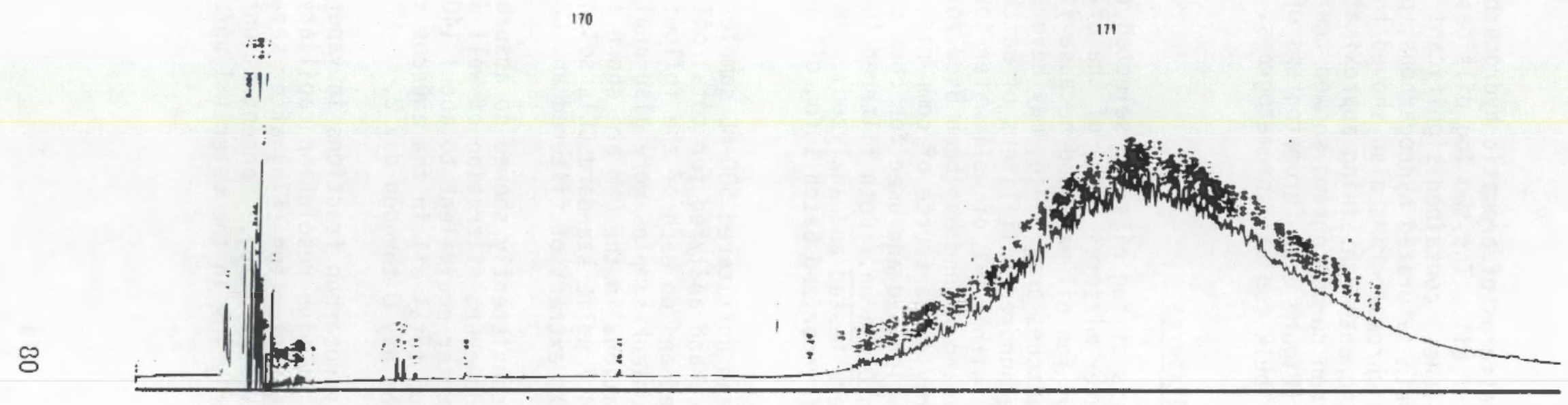

Figure 8. Gas chromatogram of a fog oil aromatic hydrocarbon fraction. 
TABLE 38. INFRARED DETERMINATION OF FOG OIL CONCENTRATION OF OIL-WATER MIXTURES (OWM)

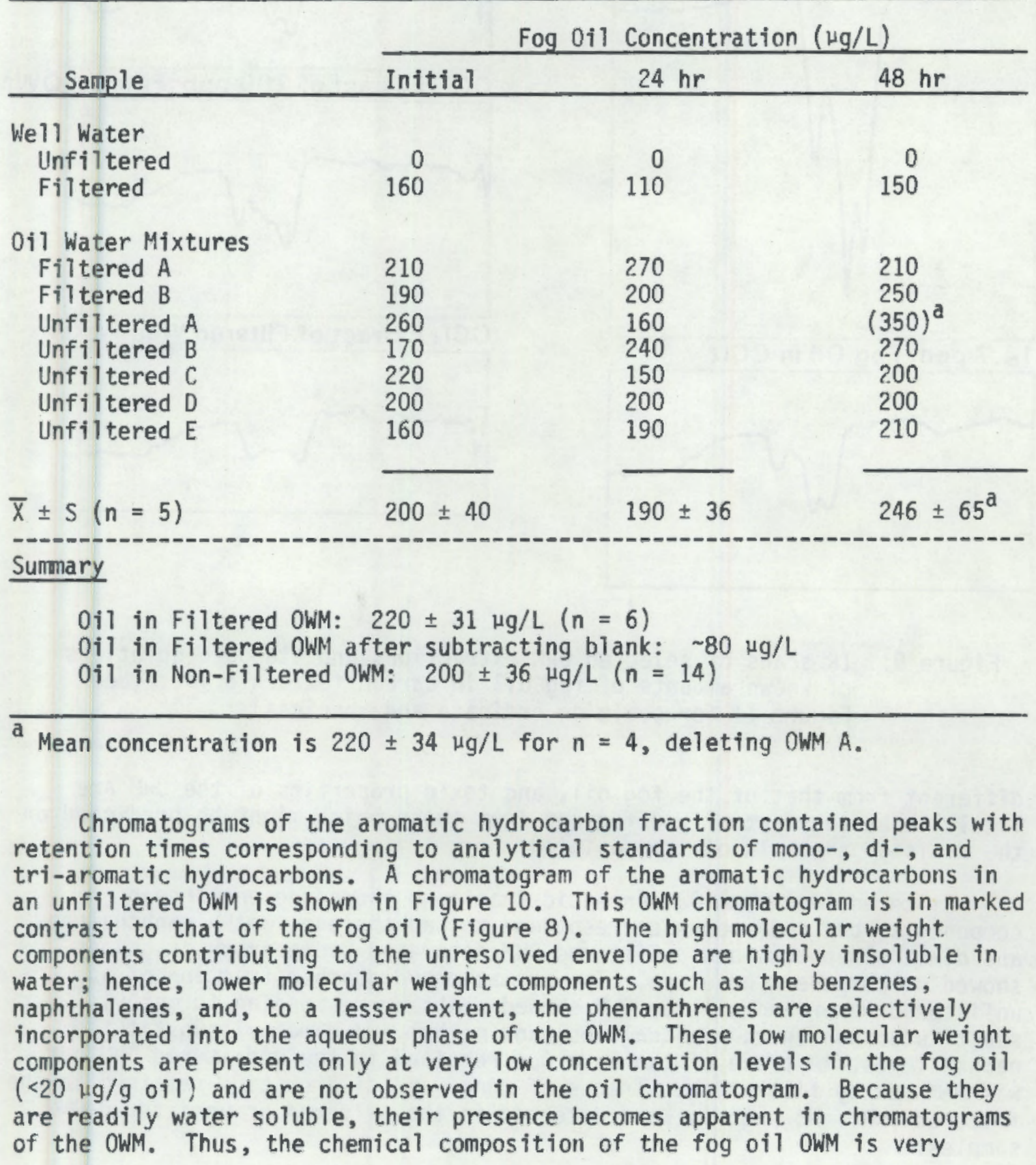


$73.8 \mathrm{ppm}$ Fog 0.1 in $\mathrm{CCl}_{4}$

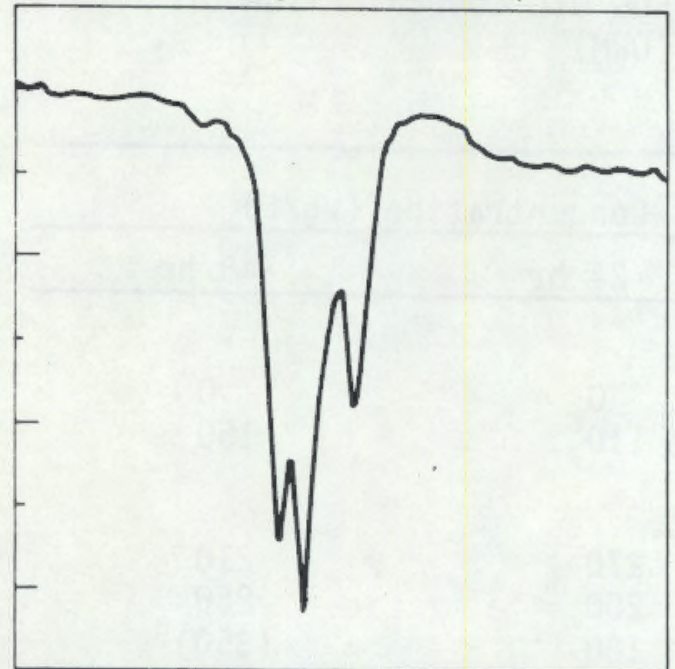

$14.7 \mathrm{ppm}$ Fog Oil in $\mathrm{CCl}_{4}$

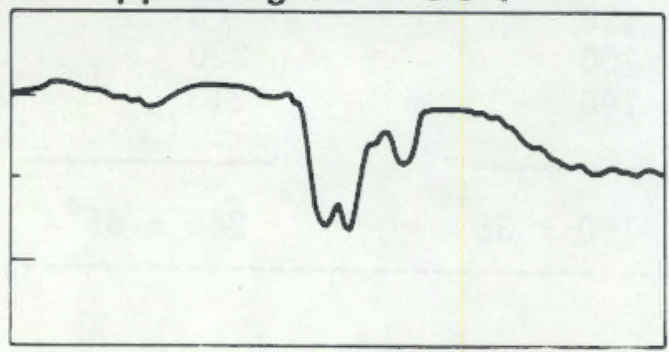

$\mathrm{CCl}_{4}$ Extract of $200 \mathrm{ppb}$ OWM
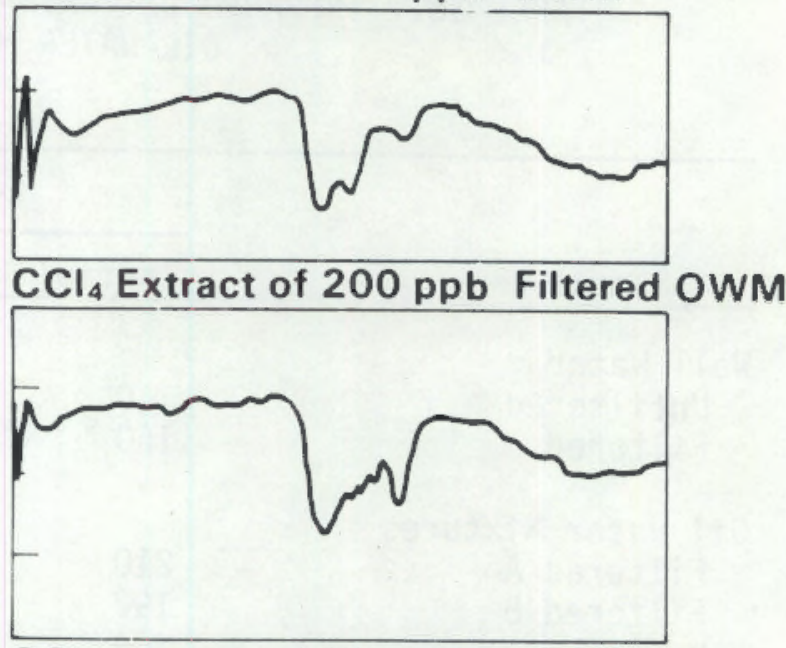

$\mathrm{CCl}_{4}$ Extract of Filtered Well Water

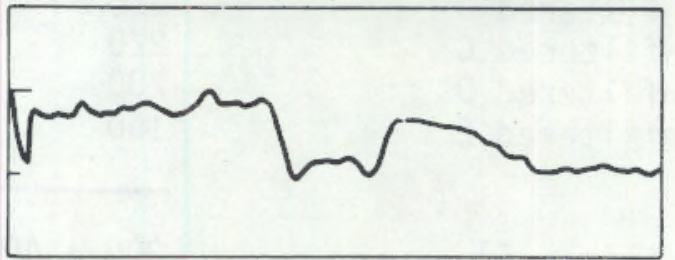

Figure 9. IR scans of selected OWM extractions and standard solutions of known amounts of fog oil in carbon tetrachloride. (See Figure 11 for scale on ordinate and abscissa).

different from that of the fog $0 i 1$, and toxic properties of the OWM are likely to be substantially different from those which might be predicted on the basis of the bulk oil composition.

Filtered $(0.45 \mu \mathrm{m})$ OWM aromatic fractions showed no envelope of components, but some peaks corresponded to naphthalene, methylnaphthalenes, and dimethylnaphthalenes. Filtered OWM saturated hydrocarbon fractions showed no component envelope. The aromatic hydrocarbon fraction of an unfiltered vaporized oil fog OWM showed peaks corresponding to methyl substituted benzenes, naphthalenes, and methyl and dimethyi substituted naphthalenes. A trace of the envelope remained in the unfiltered OWM but was removed by filtration. Traces of mono- and di-aromatics remained in the filtered OWM. No phenols were detected in the filtered or unfiltered OWM samples.

Concentrations of various aromatic hydrocarbons and their alkyl substituted analogs in the OWM of bulk and vaporized Batch 1 fog oils were 


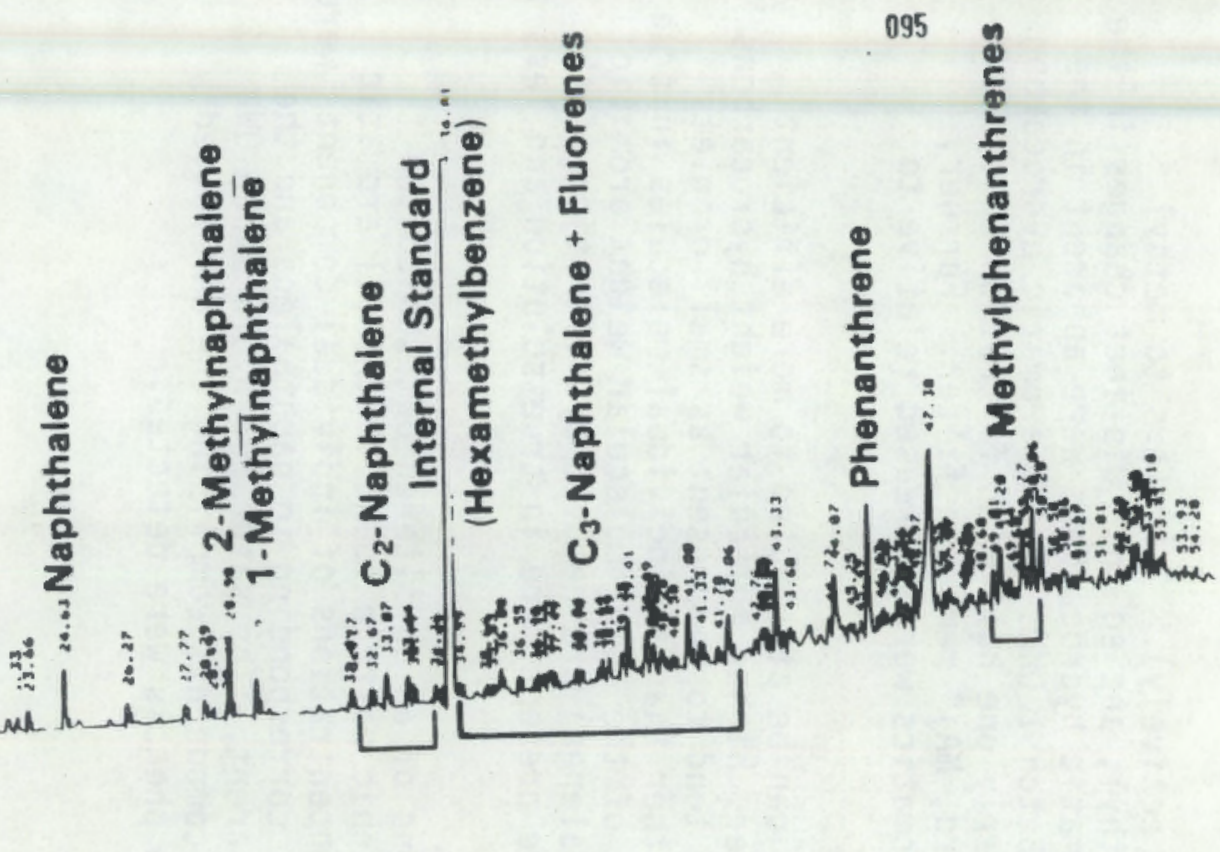

Figure 10. Chromatogram of the aromatic hydrocarbons from an unfiltered OWM of fog oil. 
calculated (Tables 39 and 40 , respectively). $C_{1}$ refers to methyl substitution, $\mathrm{C}_{2}$ to dimethyl or ethyl, and so on. Distinct changes in the relative composition of total aromatic hydrocarbons were apparent in the extraction of bulk and vaporized Batch 1 OWM. Total aromatic hydrocarbon concentrations were reduced by nearly one half with filtration of the OWM through $0.45 \mu \mathrm{m}$ "Millipore (Bedford, MA)" membrane filter. Further, concentrations of mono- and di-aromatics were increased relative to tri-aromatics by filtration.

Changes caused by filtration can be attributed to more efficient removal by the filter of the larger, higher molecular weight hydrocarbons that are more water insoluble and tend to be present as small droplets dispersed throughout the water rather than as individual molecules in true aqueous solution. Lesser amounts of the lower molecular weight aromatic hydrocarbons (benzenes and naphthalenes) are removed by filtration of the water because these components are present more in true solution and less in filterable oil droplets.

Aromatic hydrocarbon fractions of an unfiltered OWM showed the "unresolved envelope" chromatographic pattern found in the oil aromatic fraction was still present but concentrations of individual components were very low and peak retention times corresponding to naphthalene and the methylnaphthalenes had become apparent. The saturated hydrocarbon OWM fraction showed small amounts of components comprising the unresolved envelope in the oil fraction. No phenols were detected.

TABLE 39. BULK FOG OIL OWM AROMATIC HYDROCARBON CONCENTRATIONS ( $\mu \mathrm{g} / \mathrm{L}$ )

\begin{tabular}{|c|c|c|c|c|c|c|c|}
\hline \multirow{2}{*}{$\begin{array}{c}\text { Aromatic } \\
\text { Hydrocarbon }\end{array}$} & \multicolumn{4}{|c|}{ Unfiltered } & \multicolumn{3}{|c|}{ Filtered } \\
\hline & $\operatorname{Rep} 1$ & Rep 2 & Mean \pm & Range & $\operatorname{Rep} 1$ & Rep 2 & Mean \pm Range \\
\hline$C$, Benzenes & 1.0 & 1.0 & $1.0 \pm$ & 0.0 & 1.3 & 1.1 & $1.2 \pm 0.18$ \\
\hline$C_{3}^{2}$ Benzenes & 0.7 & 0.7 & $0.7 \pm$ & 0.0 & 0.7 & 1.0 & $0.8 \pm 0.1$ \\
\hline$C_{4}^{3}$ Benzenes & 0.7 & 1.2 & $1.0 \pm$ & 0.2 & 0.8 & 0.8 & $0.8 \pm 0.0$ \\
\hline Naphthalene & 0.2 & 0.2 & $0.2 \pm$ & 0.0 & 0.1 & 0.2 & $0.2 \pm 0.0$ \\
\hline c Naphthalenes & 0.3 & 0.4 & $0.4 \pm$ & 0.0 & 0.2 & 0.4 & $0.3 \pm 0.1$ \\
\hline$C_{2}^{\prime}$ Naphthalenes & 0.5 & 0.5 & $0.5 \pm$ & 0.0 & 0.04 & 0.3 & $0.2 \pm 0.2$ \\
\hline$c_{3}^{2}$ Naphthalenes & 1.6 & 1.7 & $1.6 \pm$ & 0.05 & 0.5 & 1.0 & $0.8 \pm 0.26$ \\
\hline Phenanthrene & 0.5 & 0.5 & $0.5 \pm$ & 0.0 & $<0.1$ & 0.1 & $<0.1$ \\
\hline$C_{1}$ Phenanthrenes & 1.1 & 1.2 & $1.2 \pm$ & 0.0 & $\leq 0.1$ & $\underline{0.1}$ & $\leq 0.1$ \\
\hline Total & 6.6 & 7.4 & $7.0 \pm$ & 0.4 & 3.6 & 5.0 & $4.3 \pm 0.7$ \\
\hline
\end{tabular}


TABLE 40. VAPORIZED FOG OIL OWM AROMATIC HYDROCARBON CONCENTRATIONS ( $\mu \mathrm{g} / \mathrm{L})$

\begin{tabular}{|c|c|c|c|c|c|c|}
\hline \multirow{2}{*}{$\begin{array}{l}\text { Aromatic } \\
\text { Hydrocarbon }\end{array}$} & \multicolumn{3}{|c|}{ Unfiltered } & \multicolumn{3}{|c|}{ Filtered } \\
\hline & Rep 1 & Rep 2 & Mean \pm Range & Rep 1 & $\operatorname{Rep} 2$ & Mean \pm Range \\
\hline c, Benzenes & 0.7 & 0.7 & $0.7 \pm 0.04$ & 0.8 & 0.8 & $0.8 \pm 0.04$ \\
\hline$c_{3}^{2}$ Benzenes & 1.2 & 1.2 & $1.2 \pm 0.00$ & 0.9 & 1.0 & $0.9 \pm 0.09$ \\
\hline$c^{3}$ Benzenes & 3.9 & 4.2 & $4.1 \pm 0.18$ & 2.6 & 4.2 & $3.8 \pm 0.82$ \\
\hline Napphthal ene & 0.6 & 0.7 & $0.6 \pm 0.04$ & 0.5 & 0.5 & $0.5 \pm 0.01$ \\
\hline C. Naphthalenes & 1.0 & 1.3 & $1.2 \pm 0.1$ & 0.7 & 0.7 & $0.7 \pm 0.0$ \\
\hline$c^{1}$ Naphthalenes & 1.1 & 1.5 & $1.3 \pm 0.28$ & 0.4 & 0.7 & $0.5 \pm 0.25$ \\
\hline$c_{2}^{2}$ Naphthalenes & 1.8 & 2.1 & $1.9 \pm 0.27$ & 0.2 & 0.8 & $0.5 \pm 0.43$ \\
\hline Phenanthrene & 0.5 & 0.5 & $0.5 \pm 0.03$ & $<0.1$ & $<0.1$ & $<.1$ \\
\hline$c_{1}$ Phenanthrenes & $\underline{0.9}$ & $\underline{0.8}$ & $\underline{0.8 \pm 0.05}$ & $\leq 0.1$ & $\leq 0.1$ & $<0.1$ \\
\hline Total & 11.7 & 12.8 & $12.2 \pm 0.6$ & 6.1 & 9.1 & $7.6 \pm 1.5$ \\
\hline
\end{tabular}

A second vaporization of Batch 1 fog oil ( $\mathrm{FO}-3$ ) was conducted at $6 \%$ excess air $\left(\sim 1.2 \% \mathrm{O}_{2}\right)$. The 011 was collected from a glass wool plug for analysis and toxicity testing. Some differences in composition of aromatic hydrocarbons were apparent between OWM generated from the vaporized and bulk fog oil. The bulk fog oil had a relatively higher proportion of $C_{2}$ and $C_{3}$ benzenes than the vaporized oil. This can be attributed to the loss of more volatile hydrocarbons to the atmosphere during the vaporization/condensation process. An apparent decrease in the contribution of $\mathrm{C}_{3}$-naphthalenes after vaporization is not readily rationalized. There was a greater concentration of aromatics in the OWM prepared from the vaporized fog oil than in that from the bulk oil. The difference could be a result of slight changes in the physical properties of the oil (changes in viscosity, emulsifier content, etc.), or could be an uncontrollable variation in the preparation method. The total concentration of aromatic hydrocarbon was $32.9 \pm 5.2 \mathrm{\mu g} / \mathrm{L}$ (Table 41). This total concentration is somewhat higher than the aromatic hydrocarbon concentration that was found in the prior OWMs. The high concentration was attributed to the presence of components that eluted in the same retention time window as a $C_{1}$-phenanthrene analytical standard.

Because the OWM samples were not filtered, the presence of undissolved oil droplets would account for the high concentrations of higher molecular weight hydrocarbons, the high total oil concentrations, and the unresolved envelopes in the saturated and aromatic hydrocarbon chromatograms. Individual saturated hydrocarbon concentrations in both the oil and its OWM were very low and they were not quantified. Phenol concentrations in both the oil and OWM were very low $(0.17 \pm 0.04 \mu \mathrm{g} / \mathrm{g}$ oil and $0.02 \mu \mathrm{g} / \mathrm{mL}$. OWM, respectively). 
TABLE 41. VAPORIZED FOG OIL (FO-3) OWM AROMATIC HYDROCARBON FRACTION CONCENTRATION IN $\mu \mathrm{g} / \mathrm{L}$.

\begin{tabular}{lccc}
\hline Hydrocarbon & Rep 1 & Rep 2 & Mean \pm range \\
\hline$C_{2}$ Benzenes & 0.6 & 0.8 & $0.7 \pm 0.1$ \\
$C_{3}$ Benzenes & 0.6 & 0.8 & $0.7 \pm 0.1$ \\
$C_{4}$ Benzenes & 0.9 & 1.3 & $1.1 \pm 0.2$ \\
Naphthalene & 0.4 & 0.5 & $0.5 \pm 0.0$ \\
$C_{1}$ Naphthalenes & 0.3 & 0.4 & $0.4 \pm 0.1$ \\
$C_{2}$ Naphthalenes & 0.4 & 0.6 & $0.5 \pm 0.1$ \\
$C_{3}$ Naphthalenes & 2.3 & 3.9 & $3.1 \pm 0.8$ \\
Phenanthrene & 0.6 & 1.7 & $1.2 \pm 0.6$ \\
$C_{1}$ Phenanthrenes & 21.7 & $\underline{28.1}$ & $24.9 \pm 3.2$ \\
& & & $32.9 \pm 5.2$ \\
\hline
\end{tabular}

\subsubsection{Characterization of Photolyzed Fog 0ils}

Two experiments were performed with Batch 3 fog oil: a 24-hr and a 7 day photolysis exposure. Vaporized and bulk fog oil were exposed in each experiment. Photolysis caused distinct changes in the physical properties of the oil. The formation of free radicals in the oil resulted in the formation of several classes of oxidation products. Infrared (IR) spectra of the photolyzed oil indicated increases in the content of carbonyl oxygen and possibly carboxylic acids. GC/MS analysis of OWMs prepared from the photolyzed fog oil revealed the presence of ketones.

\section{Photolysis of Fog 0 il}

Photolysis of fog oil was monitored by visual inspection and by determining the number of free radicals generated by the radiation. Monitoring of free radicals was performed with a Varian electron-spin resonance spectrometer, calibrated with the stable free radical diphenylpicrylhydrazyl. The initial free radical concentration in the vaporized $0 i 1$ was higher than in the unvaporized oil, which is indicative of oxidative or pyrolytic reactions (Table 42). As exposure continued, both oils became increasingly yellow, and after $3 \mathrm{hr}$ became turbid. Free radical concentration increased steadily in the case of the unvaporized oil, but rose and then fell again in the vaporized oil before rising steadily like the unvaporized oil. Radical concentrations in both oils after 7 days were similar, although somewhat higher in the unvaporized 011 . After $24 \mathrm{hr}$, the color was orange. 
TABLE 42. FREE RADICAL CONCENTRATIONS IN PHOTOLYZED FOG OILS

\begin{tabular}{ccc}
\hline Time of Exposure & $\begin{array}{c}\text { Fog } 0 \text { il } \\
\left(10^{14} \text { radicais/g) }\right.\end{array}$ & $\begin{array}{c}\text { Vaporized Fog 0il } \\
\left(10^{14} \text { radicals/g) }\right.\end{array}$ \\
\hline 0 & 1.2 & 6.7 \\
10 min & 1.2 & 8.9 \\
20 min & 1.6 & -- \\
30 min & 2.1 & 10.1 \\
60 min & 3.4 & 6.4 \\
120 min & 9.8 & -- \\
180 min & 13.6 & 6.4 \\
270 min & 13.7 & -- \\
360 min & --.1 & 33.7 \\
24 hr & 16.5 & 56.8 \\
7 days & 68.1 & \\
\hline Separate exposure. & &
\end{tabular}

From the absorbence at $300 \mathrm{~nm}$ (200 nm for unvaporized fog oil, $244 \mathrm{~nm}$ for vaporized), it can be calculated that one half the light at this wavelength would be absorbed within the first 1 to 2 microns of the oil surface.

\section{Infrared and U1traviolet Absorbance}

The infrared spectra of thin films of photolyzed and unphotolyzed oils were obtained in order to obtain an estimate of oxygen incorporation in the form of hydroxy or carbonyl groups. Figures 11 and 12 present scans from 4000 to $1200 / \mathrm{cm}$ of the bulk Batch 3 fog oil and the corresponding vaporized oil. The scans are almost identical, with the exception that there is slightly higher absorbence in the $1730 / \mathrm{cm}$ region for the vaporized $0 i 1$. Figures 13 and 14 show the absorbence of a vaporized oil subjected to photolys is for $24 \mathrm{hr}$, compared to bulk oil amended with $10 \%$ cyclohexanone. The percent carbonyl oxygen in the amended sample is calculated to be $1.6 \%$. It is thus apparent that the concentration of carbonyl oxygen in the nonphotolyzed sample is on the order of a few hundred $\mathrm{mg} / \mathrm{L}$. Throughout the rest of the spectrum, there is no discernible difference between photolyzed and photolyzed oils. No increase in the absorption at $3600 / \mathrm{cm}$ (hydroxy 1 stretching frequency) was noted. The $-\mathrm{OH}$ absorbences in Figures 11 thru 14 in this region are probably due to water in the air.

0 il photolyzed for 7 days exhibited pronounced changes in infrared absorbence in two regions: the carbonyl region $(1650$ to $1850 / \mathrm{cm})$, and hydrogen-bonded proton region $(3200$ to $3600 / \mathrm{cm})$. Figure 15 shows the 


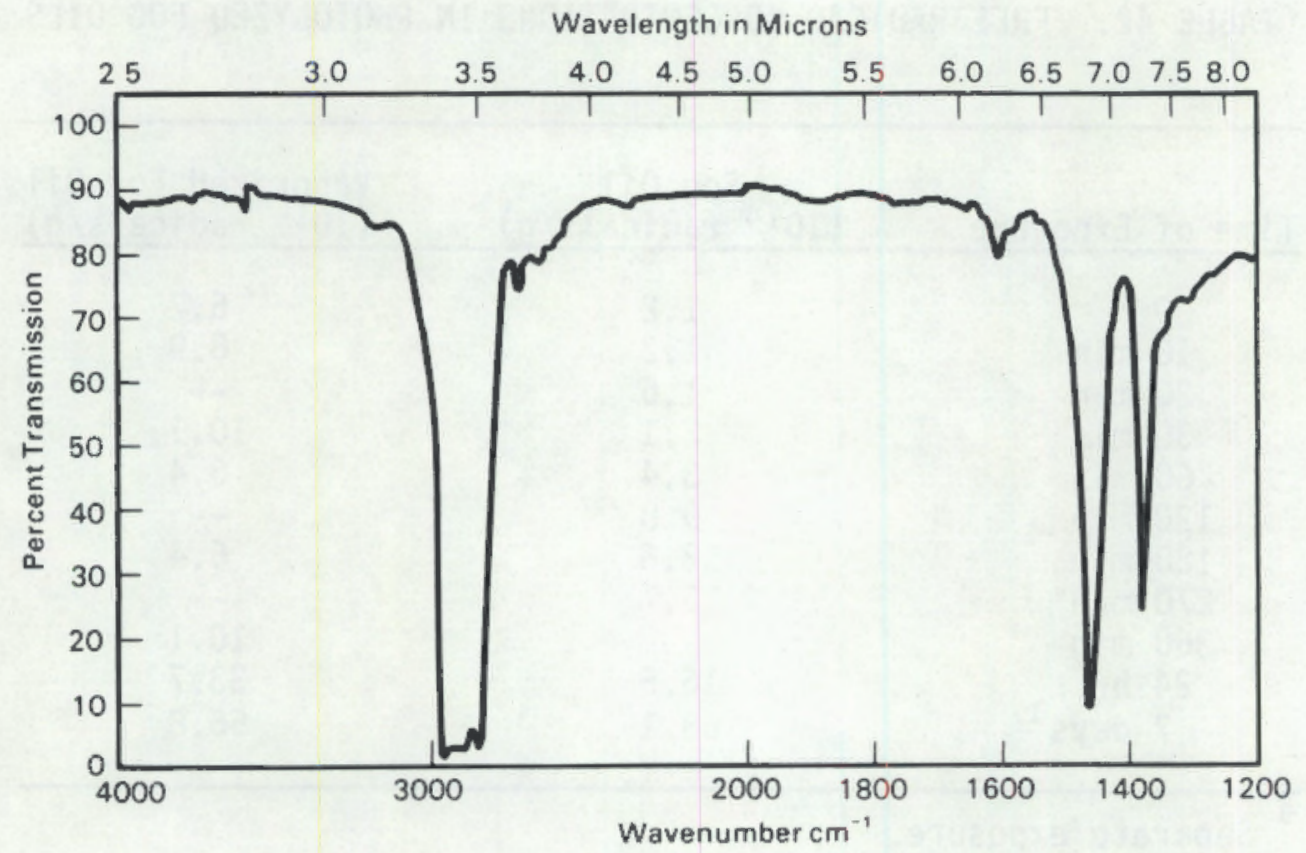

Figure 11. Infrared scans of thin films of Batch 3 bulk fog oil.

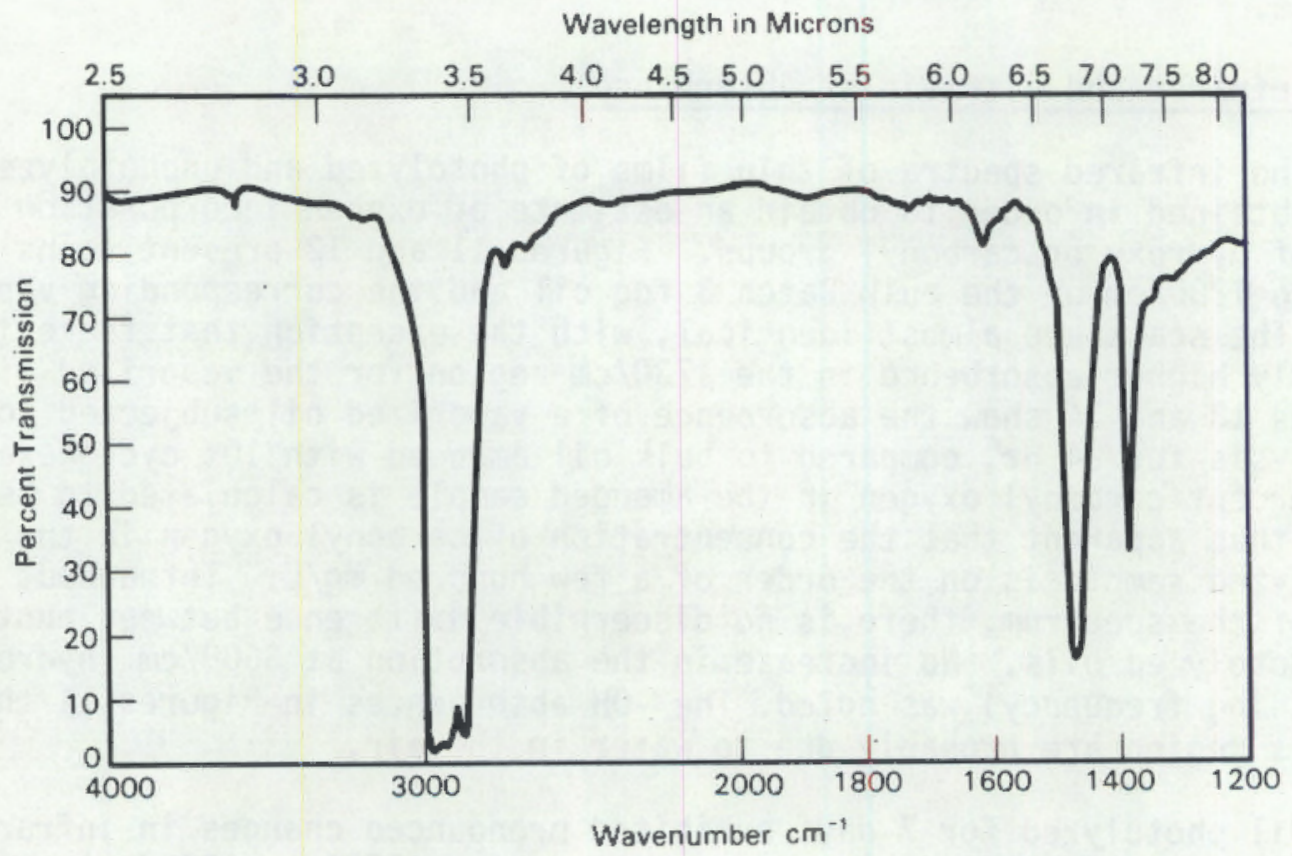

Figure 12. Infrared scan of thin film of Batch 3 vaporized fog oil. 


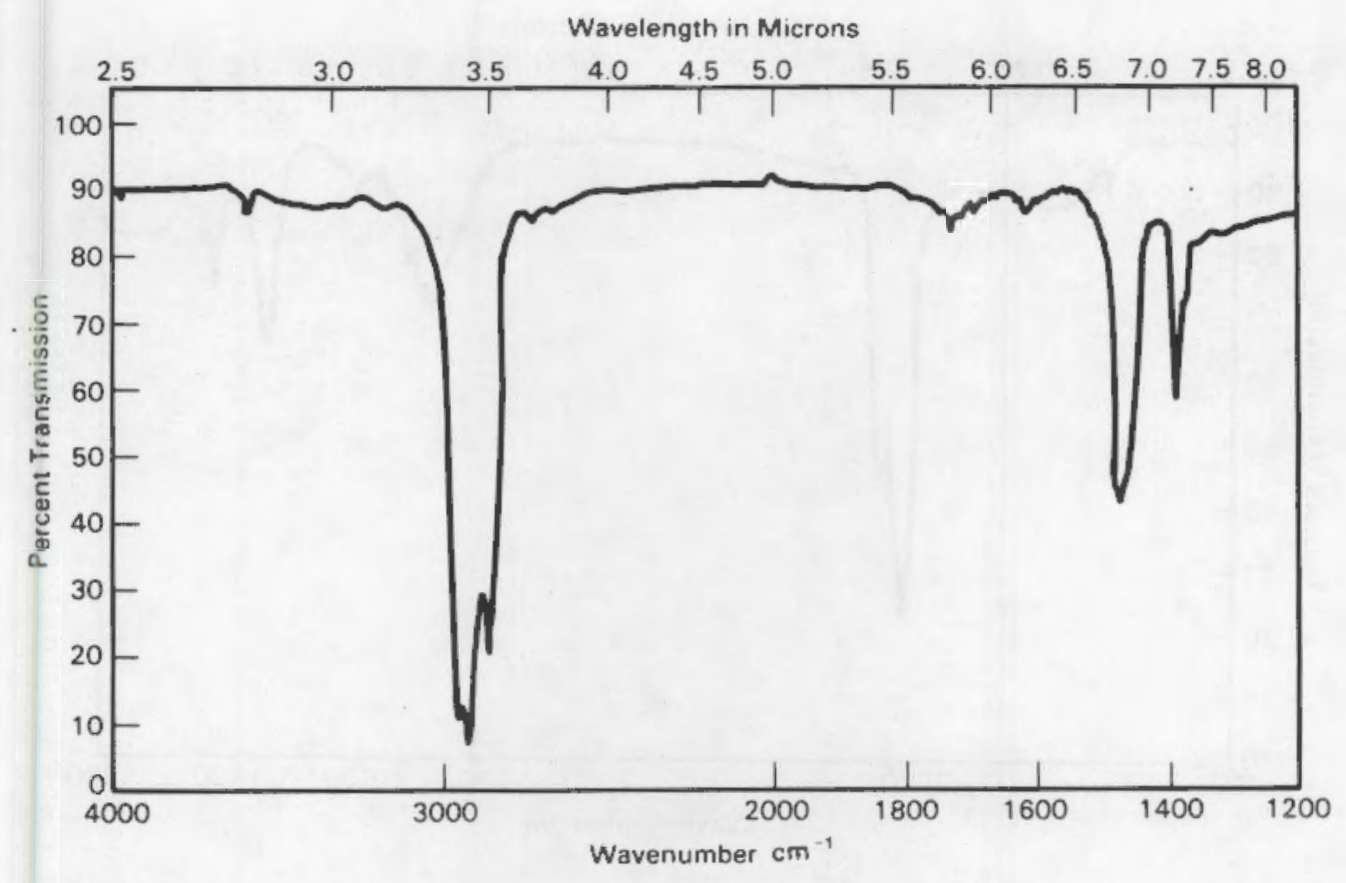

Figure 13. Infrared scans of thin films of fog oil.

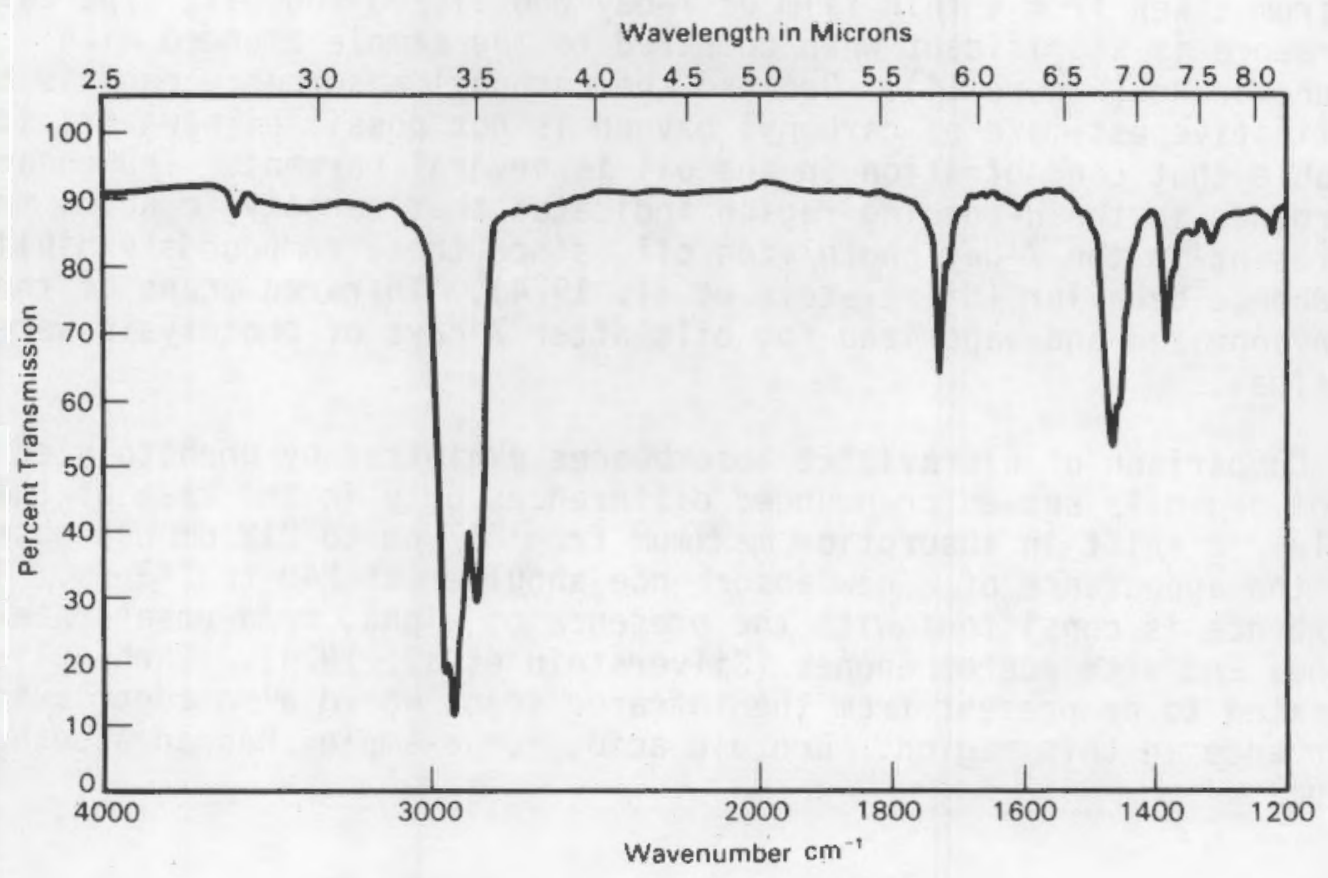

Figure 14. Infrared scan of thin film of untreated fog oil plus $10 \%$ cyclohexanone. 


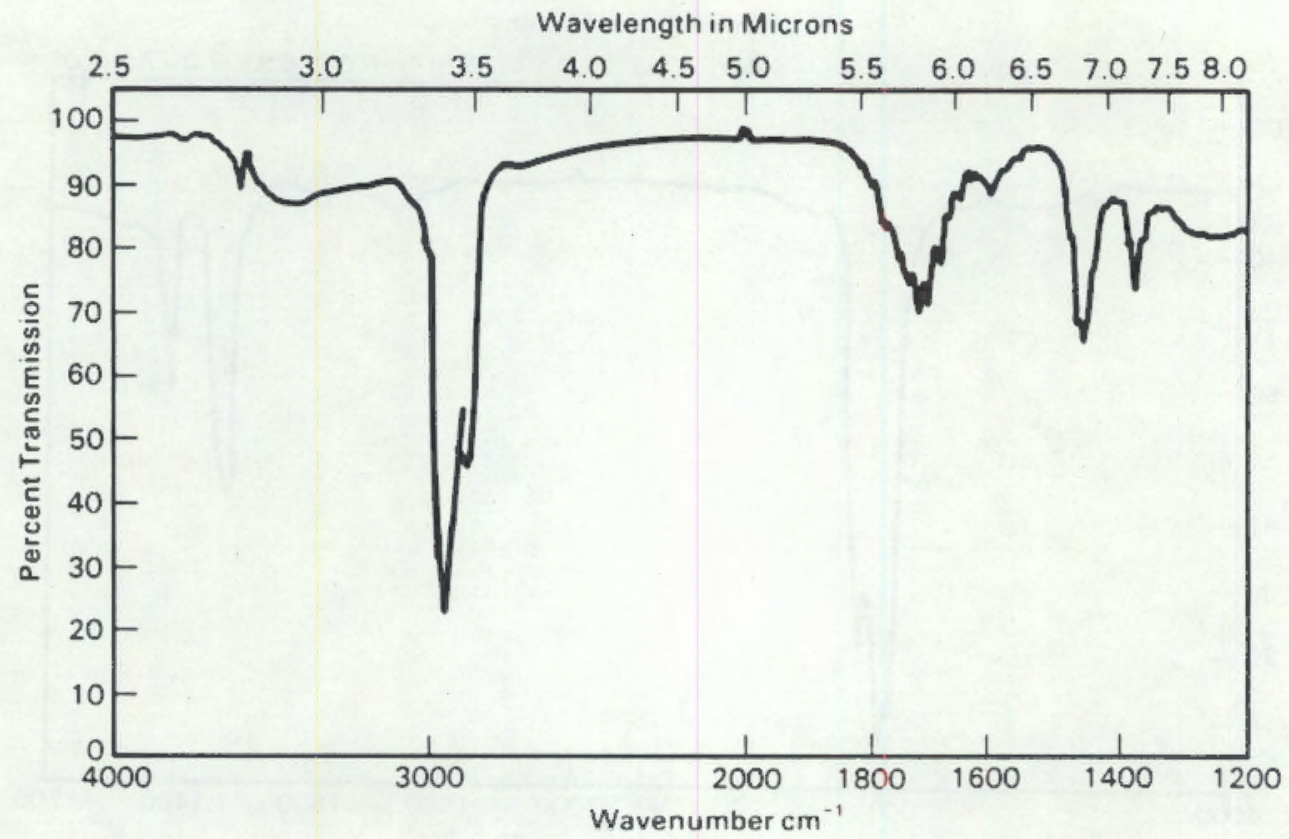

Figure 15. Infrared scan of thin film of Batch 3 fog oil photolyzed for 7 days.

spectrum taken from a thin film of 7-day photolyzed fog oil. The carbonyl absorbence is significant when compared to the sample amended with cyclohexanone (Figure 14). Because the carbonyl absorbence band is broad, a quantitative estimate of carbonyl oxygen is not possible; however, it is probable that concentration in the oil is several percent. The erinanced absorbence in the $\mathrm{H}$-bonding region indicates that carboxylic acids may also be present in the 7-day photolyzed oil, since these compounds exhibit this absorbence behavior (Silverstein et al. 1974). Infrared scans of thin films of unvaporized and vaporized fog oils after 7 days of photolysis were identical.

Comparison of ultraviolet absorbences exhibited by unphotolyzed and photolyzed oils showed pronounced differences only in the case of the 7-day sample. A shift in absorption maximum from $217 \mathrm{~nm}$ to $212 \mathrm{~nm}$ was observed, with the appearance of a new absorbence shoulder at 240 to $248 \mathrm{~nm}$. This absorbence is consistent with the presence of alpha, beta-unsaturated ketones and with acetophenones (Silverstein et al. 1974). Carboxylic acids, indicated to be present from the infrared scan, would also contribute to the absorbence in this region. Benzoic acid, for example, has an absorbence at $230 \mathrm{~nm}$. 
Gas Chromatographic Analysis of OWM of Photolyzed 0ils

Water extraction of 24-hr photolyzed oils was conducted with vigorous stirring, and oil concentrations in water were higher than previous extracts used for toxicity testing. Isooctane extracts of $20 \mathrm{~mL}$ of the water-soluble fractions, initially used for determination of total oil, were examined by gas chromatography. Chromatograms obtained of vaporized and $14 \mathrm{hr}$ photolyzed/vaporized fog oil using nonpolar bonded phase capillary columns are presented in Figures 16 and 17, respectively. The photolyzed material (Figure 17) contains more lower molecular weight material, as indicated by the somewhat higher peaks at early retention times. The column used would not elute highly polar compounds (carboxylic acids, alcohols, etc.). The infrared scans discussed above indicate that concentrations of polar compounds in the 24-hr photolyzed bulk oil are low. However, aqueous extraction would tend to selectively remove polar materials, and therefore they should be a significantly higher percentage of the water soluble fraction. The unresolved envelopes of material that are the predominant features of the chromatograms in Figure 16 and 17 indicate that, for the most part, the material extracted into the water for this experiment consisted of unchanged hydrocarbons.

When the water soluble fraction of unvaporized, 24-hr photolyzed oil was analyzed by capillary gas chromatography using a mass-selective detector (Hewlett-Packard Model 5970A), seven components were found in the early retention fraction of the photolyzed 011 that were not present in the unphotolyzed oil. The identity of these compounds could not be established, because the components were not resolved sufficiently from other oil compounds to yield unambiguous spectra. The concentrations of these in the water were at most in the $\mu \mathrm{g} / \mathrm{L}$ range. The changes brought about by photolysis for $24 \mathrm{hr}$, while readily apparent to the eye, apparently did not profoundly affect the overall chemical composition of the water soluble extract. However, small changes in composition can have significant effects on the physical properties of the oil by producing changes in surface tension and water miscibility and emulsification.

The changes in the infrared spectrum of the 7-day photolyzed oils indicated significant amounts of oxygenated material had been formed. Therefore, water-soluble fractions used for toxicity testing were examined for components containing highly polar hydroxyl groups, using a derivatization procedure. In addition, hexane extracts of the water samples were directly injected into the gas chromatograph.

Samples of water used for toxicity testing $(50 \mathrm{~mL})$, were extracted twice with $10 \mathrm{~mL}$ hexane. The extracts were concentrated to $1 \mathrm{~mL}$ in n-heptane. The extracts were injected onto a $60 \mathrm{~m}$ capillary column in a gas chromatograph programmed from $70^{\circ}$ to $250^{\circ} \mathrm{C}$ at $4^{\circ} \mathrm{C} / \mathrm{min}$. Detection was with a mass-selective detector, scanning from mass 40 to 300 . A total ion chromatogram obtained from the vaporized, 7-day photolyzed aquecus extract is presented in Figure 18. Tentative assignment of structure has been made for several of the major components in the chromatogram. 


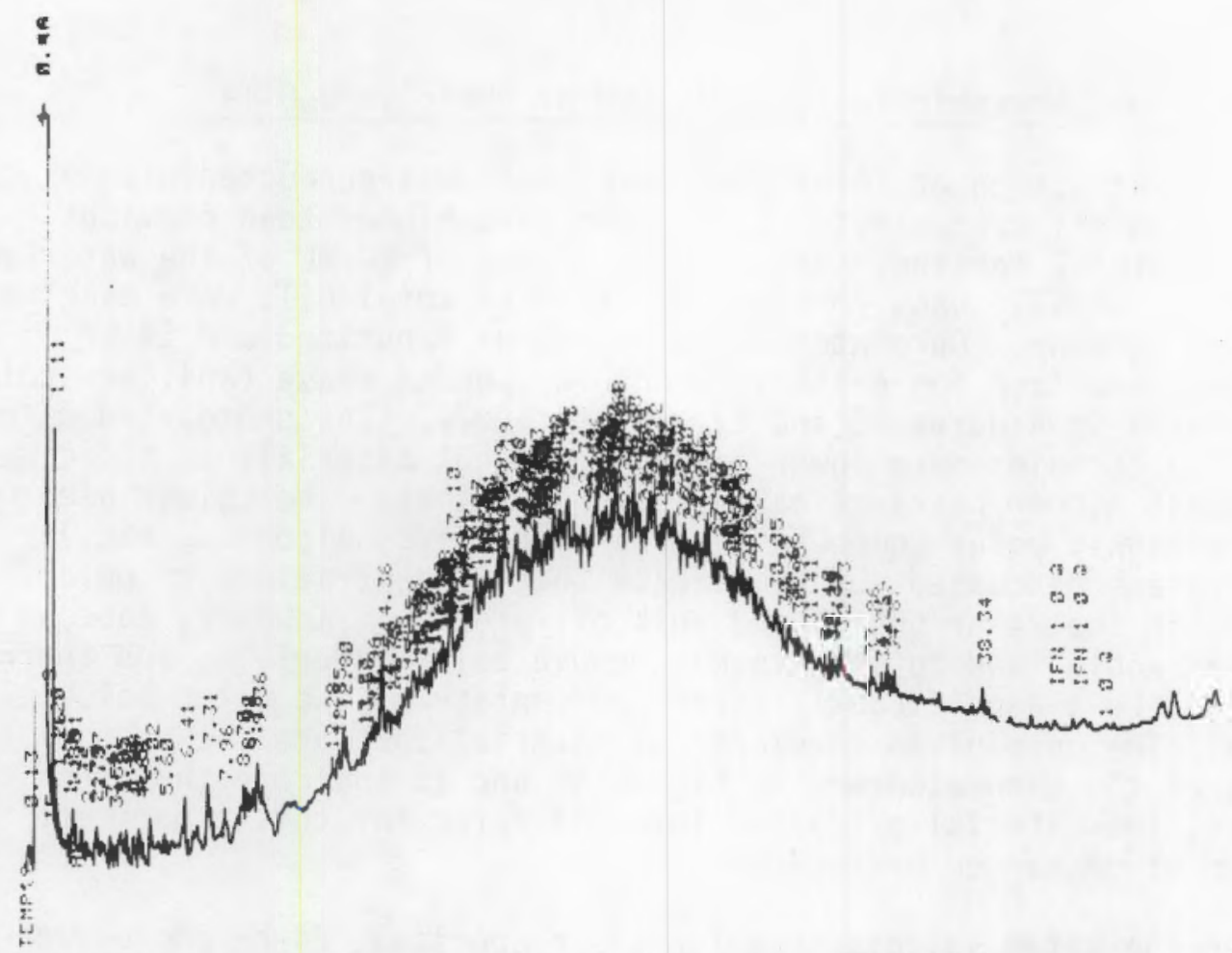

Figure 16. Capillary gas chromatogram of isooctane extract of water soluble fraction of vaporized fog oils.

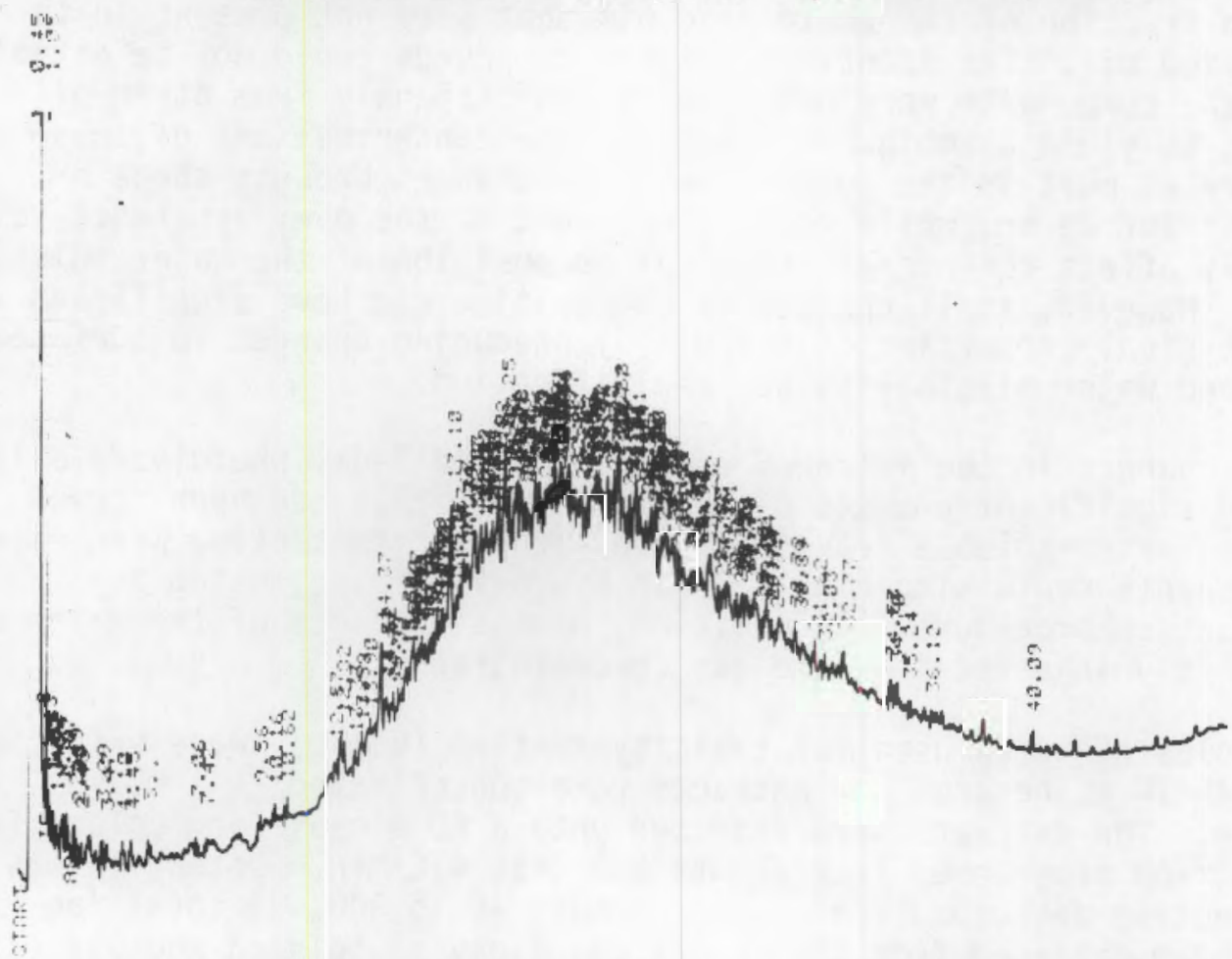

Figure 17. Capillary gas chromatogram of isooctane extract of water soluble fraction of 24-hr photolyzed/vaporized fog oil. 

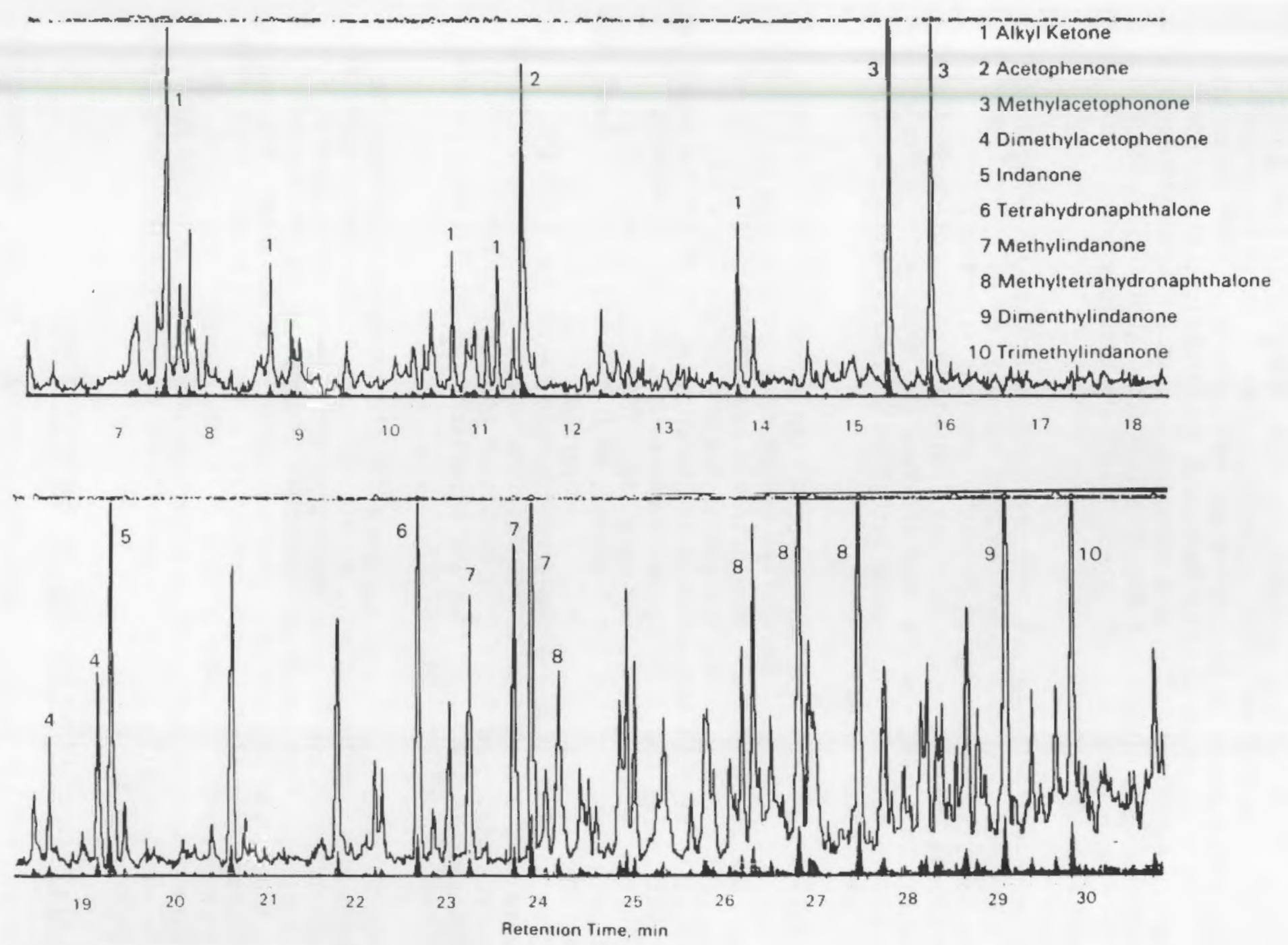

Figure 18. Total ionization chroriatograri of hexane-extractable components from water soluble fraction of vaporized, 7-day photolyzed fog oil. 
Initial structural assignments were made by referring to the "Eight. Peak Index" (Mass Spectrometry Data Centre 1974), and comparing with published spectra of related compounds found in the EPA/NIH Mass Spectral Data Base (Heller and Milne 1978). Identification of exact structural isomers requires comparison of spectra and retention time with authentic standards. It is stressed that without such confirmation, the proposed structures are tentative. They are consistent, however, with the absorption spectra for the 7-day photolyzed fog oils discussed above. Chromatograms obtained from both vaporized and unvaporized 7-day photolyzed oil test water were essentially the same.

The hexane extract obtained from the stock solutions of unphotolyzed oil gave a chromatogram with no evidence of ketones, or of hydrocarbons related to fog oil. In the water from the previous experiment involving 24-hr photolysis, an unresolved envelope indicative of fog oil was present in the gas chromatogram. In the case of the 7-day photolysis, stirring was much less vigorous. Conditions were such that only truly water-soluble components were solubilized.

The hexane extracts were next treated with a powerful derivatizing agent, Sylon BTZ, that will form silyl ethers from hydroxylated (alcohol) compounds. The concentrated hexane extracts were treated with $0.1 \mathrm{~mL}$ of Sylon BTZ, left overnight, and the excess reagent decomposed with $3 \%$ ammonia. The treated samples were chromatographed as described above for the underivatized extracts. Components emerging from the column were monitored using the mass-selective detector. The detector was set to detect all components giving ion fragments of $M=73$ and $M=45$. These ions are characteristic of silyl ethers. A comparison of a single ion chromatogram obtained from the photolyzed sample, with that from the unphotolyzed sample showed no substantial difference between them. It is concluded from this experiment that compounds containing hydroxyl groups were not present in the water from the photolyzed oil in any excess over that from the unphotolyzed oil.

Although there is infrared evidence for the presence of carboxylic acids in the 7-day photolyzed 0 il, we did not investigate the possibility that carboxylated compounds were present in the aqueous extracts used for toxicity testing. They would not have been detected using the methods described above, and may not have been extracted from the water with hexane under the conditions used. Since carboxylic acids could have considerable influence on toxicity, as well as on the physical properties of the OWM, further work should be conducted to determine whether these compounds contribute substantially to the composition of the water-soluble fraction from photolyzed oils.

\subsubsection{Evaluation of Other Methods for Monitoring OWMs}

Total organic carbon and liquid chromatographic methods were investigated for monitoring ObiMs and were found to be unsuitable. Measurement of 
total organic carbon (TOC) has been successfully employed as a monitoring tool in previous studies of suspensions of coal liquids in water (Bean et a). 1981). The use of TOC measurement as a rapid oil monitoring tool was briefly investigated. The incentive for use of TOC is that results can be obtained very rapidly. However, the data presented in Table 43 demonstrate that TOC cannot be used to monitor oil concentrations effectively in Fog 0 il 0WMs. Total carbon (TC) was composed primarily of carbonate carbon, which was removed from the sample by acidification and sparging the sample with oxygen gas. The carbon remaining after removal of carbonate is designated TOC.

The problem with using TOC was that the background levels of organic carbon are about $3 \mathrm{mg} / \mathrm{L}$, which are an order of magnitude higher than Tevels of $0 i 1$ as measured by IR $(0.2 \mathrm{mg} / \mathrm{L})$. Therefore, no difference in TOC concentration could be detected between well water samples and OWM samples.

\section{Liquid Chromatography}

A brief investigation of liquid chromatography to determine total oil in the OWM was also conducted. Injection of up to $200 \mathrm{~mL}$ of the OWM onto a reverse-phase bcnded n-octadecane column did not produce an absorbence envelope which could be quantitated. Both methanol and acetcnitrite were used as eluting solvents without positive results. It was concluded that an LC method, although feasible, would be difficult to develop for OWMs having $0 i 1$ concentrations much lower than $1 \mathrm{mg} / \mathrm{L}$, and would have little advantage over the infrared absorbence method.

\subsubsection{Toxicity of SGF No. 2 Fog 011}

Preliminary toxicity tests with $D$. magna were performed on oil-water dispersions of bulk and vaporized fog oiT during Phase I of the project. During Phase II, screening toxicity tests were performed with the green alga $S$. capricornutum, P. promelas, and mayfly larvae (Hexagenia sp.) with

TABLE 43. MEASURED TOTAL ORGANIC CAR8ON ( $\mathrm{\mu g} / \mathrm{L})$ IN FILTERED AND NON-FILTERED OIL/WATER MIXTURES AND WELL WATER SAMPLES

\begin{tabular}{lrrr}
\hline & Initial & $24 \mathrm{hr}$ & $48 \mathrm{hr}$ \\
\hline Well Water & & & \\
We11 Water, Filtered & $3.20 \pm 0.76$ & $2.24 \pm 0.31$ & $2.25 \pm 0.28$ \\
OWh & $3.10 \pm 0.39$ & -- & -18 \\
OWM, Filtered & $3.70 \pm 1.95$ & $2.73 \pm 0.22$ & $2.16 \pm 0.18$ \\
& $3.28 \pm 0.37$ & $2.94 \pm 0.16$ & $2.83 \pm 0.28$ \\
\hline a Used to prepare the OWM from Batch 1 fog oil.
\end{tabular}


three batches of SGF No. 2 fog oil. Batch 3 was selected for additiorial studies to determine the effect of vaporization and photolysis on the chemistry and toxicity of the fog oil. Toxicity testing continued in Phase II with $\underline{P}$. promelas, $\underline{D}$. magna, $\underline{P}$. dissimilus and $\underline{H}$. azteca.

\section{Phase I Tests}

Preliminary toxicity tests were performed with filtered $(0.45 \mu m)$ and unfiltered OWMs prepared from a $30 . \mathrm{L}$ standard slow mix at $174 \mathrm{rpm}$. In this initial mix, the plastic propeller was positioned $15 \mathrm{~cm}$ below the surface of the water. Vaporized (FO-1) and unvaporized Batch 1 fog oils were used in the slow mix preparations. Exposure solutions were prepared with $10 \%$ to $100 \%$ of the filtered and unfiltered OWM for the vaporized and bulk Batch 1 fog 0il. There was no mortality over $96 \mathrm{hr}$ in any of the treatments of the filtered OWM for either vaporized or bulk fog oil. In tests with the unfiltered $0 \mathrm{WM}$, the exposed organisms imediately floated to the surface; floating appeared to be dose-dependent (Table 44). After $24 \mathrm{hr}$, "floaters"

TABLE 44. SUMMARY OF MORTALITIES (\%) AND FLOATERS (\%) FRON SCREENING TOXICITY TESTS OF BULK AND VAPORIZED (FO-1) BATCH 1 FOG OIL ${ }^{2}$

\begin{tabular}{|c|c|c|c|c|c|c|c|c|c|c|c|c|}
\hline \multirow[b]{3}{*}{ Dilution } & \multirow[t]{2}{*}{$2.5 \mathrm{hr}$} & \multicolumn{2}{|c|}{$24 \mathrm{hr}$} & \multicolumn{3}{|c|}{$48 \mathrm{hr}$} & \multicolumn{3}{|c|}{$72 \mathrm{hr}$} & \multicolumn{3}{|c|}{$96 \mathrm{hr}$} \\
\hline & & \multicolumn{2}{|c|}{ Floaters } & \multicolumn{3}{|c|}{ Floaters } & \multicolumn{3}{|c|}{ Floaters } & \multicolumn{3}{|c|}{ Floaters } \\
\hline & Floaters & $\overrightarrow{\text { Dead }}$ & Alive & Mort. & Dead & Alfve & Mort. & Dead & Alfye & Mort. & Dead & Alive \\
\hline
\end{tabular}

\begin{tabular}{|c|c|c|c|c|c|c|c|c|c|c|c|}
\hline $\begin{array}{l}\text { Controi } \\
10 \% \\
20 \% \\
40 \% \\
60 \% \\
100 \%\end{array}$ & $\begin{array}{r}4.2 \\
4.2 \\
12.5 \\
58.3 \\
58.3 \\
100\end{array}$ & $\begin{array}{l}0 \\
0 \\
0 \\
0 \\
0 \\
0\end{array}$ & $\begin{array}{c}0 \\
0 \\
0 \\
41.7 \\
75.0 \\
700\end{array}$ & $\begin{array}{l}0 \\
0 \\
0 \\
0 \\
0 \\
0\end{array}$ & $\begin{array}{l}0 \\
0 \\
0 \\
0 \\
0 \\
0\end{array}$ & $\begin{array}{c}0 \\
0 \\
0 \\
25.0 \\
62.5 \\
100\end{array}$ & $\begin{array}{c}0 \\
0 \\
0 \\
4.2 \\
41.7 \\
50.0\end{array}$ & $\begin{array}{c}0 \\
0 \\
0 \\
0 \\
33.3 \\
50.0\end{array}$ & $\begin{array}{c}D \\
0 \\
0 \\
25 \\
29.2 \\
45.8\end{array}$ & $\begin{array}{c}0 \\
0 \\
4.2 \\
66.7 \\
95.8 \\
95.8\end{array}$ & $\begin{array}{c}0 \\
0 \\
0 \\
20.8 \\
66.7 \\
95.8\end{array}$ \\
\hline $\begin{array}{l}\text { Control } \\
108 \\
208 \\
408 \\
60 \% \\
100 \%\end{array}$ & $\begin{array}{c}0 \\
0 \\
4.2 \\
50.0 \\
66.7 \\
70.8\end{array}$ & $\begin{array}{l}0 \\
0 \\
0 \\
0 \\
0 \\
0\end{array}$ & $\begin{array}{c}0 \\
0 \\
8.3 \\
25.0 \\
20.8 \\
33.3\end{array}$ & $\begin{array}{l}0 \\
0 \\
0 \\
0 \\
0 \\
0\end{array}$ & $\begin{array}{l}0 \\
0 \\
0 \\
0 \\
0 \\
0\end{array}$ & $\begin{array}{c}0 \\
0 \\
4.2 \\
20.8 \\
29.2 \\
37.5\end{array}$ & $\begin{array}{c}0 \\
0 \\
0 \\
33.3 \\
29.2 \\
12.5\end{array}$ & $\begin{array}{r}0 \\
0 \\
0 \\
20.8 \\
8.3 \\
12.5\end{array}$ & $\begin{array}{l}0 \\
0 \\
4.2 \\
4.2 \\
12.5 \\
29.2\end{array}$ & $\begin{array}{c}0 \\
0 \\
25.0 \\
100 \\
100 \\
87.5\end{array}$ & $\begin{array}{c}0 \\
0 \\
12.5 \\
29.2 \\
12.5 \\
37.5\end{array}$ \\
\hline
\end{tabular}

\footnotetext{
Mortality columns contain dead floaters and dead Instars lying on the bottom of exposure beakers.
}

All floaters at $2.5 \mathrm{hr}$ mere alive. 
persisted in the $20 \%$ and higher treatments for the duration of the test. Mortality was not observed until $72 \mathrm{hr}$. The floating phenomenon resulted from either adherence of oil to the organism's carapace or internal accumulation of microdroplets by filtration.

The OWM were initially set up to test extraction and analytical procedures. The preliminary analys is for total oil in the stock solutions yielded conflicting results, and the concentration of total oil in the OWMs was believed to be 0.2 to $0.3 \mathrm{mg} / \mathrm{L}$. The mortality observed in the tests can be attributed to the physical stress of floating, chemical toxicity of the oil, starvation, or interactions from any combination of these factors. Comparatively, there were more floaters in the bulk oil test than in the vaporized fog oil test. Uncertainties in the amount of oil present in the stock solutions prevent a direct comparison of the toxicity of the vaporized and bulk Batch 1 fog oil.

A second 48-hr screening toxicity test was prepared in Phase I with vaporized Batch 1 fog oil that had been collected on a glass wool plug (F0-3). The slow mix was modified to accommodate the smaller volume of vaporized oil available for testing. The ratio of oil to water was kept constant (1:99), and the propeller blades were positioned $2.5 \mathrm{~cm}$ below the surface of the water. Positioning the propeller closer to the surface of the water created more mixing energy and, therefore, dispersed more oil into the stock solutions. The resulting concentration of total oil (by IR) in the stock solution was $1.8 \mathrm{mg} / \mathrm{L}$, roughly 10 times higher than that of the stock solution of the initial screening tests. Floaters were more prevalent in all the concentrations tested (Table 45). It is not surprising that some degree of mortality was associated with the $10 \%$ solutions at $48 \mathrm{hr}$ since total ojl concentrations in the $10 \%$ exposure solutions were comparable to

TABLE 45. MORTALITY DATA OF D. MAGNA EXPOSED TO OWM OF BATCH 1 VAPORIZED FOG OIL (FO-3)

\begin{tabular}{|c|c|c|c|c|c|}
\hline \multirow[b]{2}{*}{$\%$ Stock } & \multirow{2}{*}{$\begin{array}{c}0 \mathrm{il} \\
\mathrm{mg} / \mathrm{mL}\end{array}$} & \multicolumn{2}{|c|}{$24 h r^{a}$} & \multicolumn{2}{|c|}{$48 h r^{a}$} \\
\hline & & ATive & Dead & ATive & Dead \\
\hline 100 & 1.8 & 20 & 0 & 5 & 15 \\
\hline 60 & 1.1 & 19 & I & 7 & 13 \\
\hline 40 & 0.8 & 20 & 0 & 13 & 7 \\
\hline $2 \mathrm{D}$ & 0.4 & 21 & 0 & 12 & 9 \\
\hline 10 & 0.2 & 20 & 0 & 12 & 8 \\
\hline Control & 0 & 20 & 0 & 20 & 0 \\
\hline
\end{tabular}

a AT test organisms were floating except controls. 
the stock solution of the initial test. 0il slicks had developed after $24 \mathrm{hr}$ in the more concentrated exposure solutions, indicating that suspended oil droplets in the stock solution were not in equilibrium with the truly dissolved fog oil. It was not possible to ascertain whether or not the fog $0 i 1$ that had vaporized in the presence of $\sim 1.2 \% \mathrm{O}_{2}$ was more toxic than the initial FO-1 vaporized fog oil. The comparison was not possible because of differences in mixing and the amount of oil in the stock solutions. Interpretation of toxicity results was complicated by the presence of excessive amounts of $0 i]$, which made it difficult to separate chemical toxicity from physical effects of the oil.

\section{Phase II Tests}

Phase II screening toxicity tests were performed with $\mathrm{P}$. promelas, Hexagenia Sp. and the green alga $S$. capricornutum. Hexagenta was tested because its relatively large size would minimize the potential for physical effects of the oil interfering with the interpretation of test results. Moreover, the large surface area of exposed abdominal gills would predisposed this species to absorbtion of dissolved fog oil. Consequently the species intuitively could be one of the more sensitive aquatic species avallable for testing.

The results of screening toxicity tests with $\underline{P}$. promelas and Hexagenia are sumarized in Tables 46 and 47 , respectively. Generally, the stock solutions generated from the fish tests contained less total fog oil at the start of the tests than the stock solutions generated for testing Hexagenia. After $24 \mathrm{hr}$, fog $0 i 1$ slicks were visible in the $10 \%$ and $100 \%$ exposure solutions indicating that the amount of oil present at the start of the tests exceeded the solubility of fog oil in water. This suggests that soluble components of the fog oil were not present in sufficient quantities to be toxic. Dissolved oxygen did not decrease over the $96 \mathrm{hr}$ duration of the $\mathrm{P}$. promelas tests indicating that the fog oil has very low potential for creating a chemical oxygen demand. Based on a lack of dose dependent toxicity in these screening tests, the toxicity of the three batches of fog oil were judged to be relatively non-toxic to invertebrates and fish.

The algal toxicity tests with $S$. capricornutum pointed towards an indication of toxicity in the more concentrated exposure solutions. Comparatively, Batch 1 and Batch 2 tests showed significant growth inhibition at $96 \mathrm{hr}$. There was an indication that the lower exposure concentrations of fog oil may have stimulated algal growth, but the difference in mean cell counts of these treatments were equivalent to cell counts in the control treatments (Table 48). In all algal tests, differences in treatments did not become apparent until $96 \mathrm{hr}$ of exposure. With the exception of the Batch 1 test, growth inhibition was either not significant or was less than $50 \%$ at $96 \mathrm{hr}$ in all tests with bulk and vaporized fog $011(\mathrm{FO}-4)$. Consequently, EC5D concentrations were not calculated. 
TABLE 46. SUMMARY OF 96-HR BATCH SCREENING TOXICITY TESTS WITH PIMEPHALES PROMELAS

\begin{tabular}{|c|c|c|c|c|}
\hline Treatment & $\begin{array}{c}\text { Total } 0 i 1 \\
(\mathrm{mg} / \mathrm{L})\end{array}$ & Mortality & $\begin{array}{c}\text { 96-hr Data } \\
\text { Combined }\end{array}$ & $\begin{array}{r}0.0 \\
(\mathrm{mg} / \mathrm{L}) \\
\end{array}$ \\
\hline \multicolumn{5}{|c|}{ - } \\
\hline $\begin{array}{r}\text { Control } \\
\text { Control } \\
18 \\
18 \\
108 \\
10 \% \\
100 \% \\
100 \%\end{array}$ & $\begin{array}{l}0.16 \\
0.16 \\
0.16 \\
0.16 \\
0.55 \\
0.55 \\
1.11 \\
1.11\end{array}$ & $\begin{array}{l}0 / 8 \\
0 / 8 \\
0 / 8 \\
0 / 8 \\
0 / 8 \\
0 / 8 \\
0 / 8 \\
0 / 8\end{array}$ & $\begin{array}{l}08 \\
08 \\
08 \\
08\end{array}$ & $\begin{array}{l}7.7 \\
8.0 \\
7.7 \\
7.6 \\
8.0 \\
7.5 \\
7.7 \\
7.8\end{array}$ \\
\hline \multicolumn{5}{|c|}{ (1) } \\
\hline $\begin{array}{r}\text { Control } \\
\text { Control } \\
1004 \\
1008\end{array}$ & $\begin{array}{l}0.05 \\
0.05 \\
0.64 \\
2.37\end{array}$ & $\begin{array}{l}1 / 10 \\
0 / 10 \\
0 / 10 \\
0 / 10\end{array}$ & $\begin{array}{l}58 \\
08\end{array}$ & $\begin{array}{l}\text { Not Measured } \\
\text { Not Measured } \\
\text { Not Measured } \\
\text { Not Measured }\end{array}$ \\
\hline \multicolumn{5}{|c|}{ - } \\
\hline $\begin{array}{r}\text { Control } \\
\text { Control } \\
1008 \\
1008\end{array}$ & $\begin{array}{l}0.05 \\
0.05 \\
0.83 \\
0.45\end{array}$ & $\begin{array}{l}0 / 10 \\
0 / 10 \\
0 / 10 \\
0 / 10\end{array}$ & $\begin{array}{l}08 \\
08\end{array}$ & $\begin{array}{l}\text { Not Measured } \\
\text { Not Measured } \\
\text { Not Measured } \\
\text { Not Measurcd }\end{array}$ \\
\hline
\end{tabular}

TABLE 47. SUMMARY OF 48-HR SCREENING TOXICITY TESTS WITH HEXAGENIA

\begin{tabular}{|c|c|c|c|c|}
\hline Treatment & $\begin{array}{c}\text { Total } 0 f 1 \\
(\mathrm{mg} / \mathrm{L})\end{array}$ & Mortality & $\begin{array}{c}\text { 48-hr Data } \\
\text { Combined }\end{array}$ & $\begin{array}{r}0.0 \\
(\mathrm{mg} / \mathrm{L})\end{array}$ \\
\hline \multicolumn{5}{|c|}{ 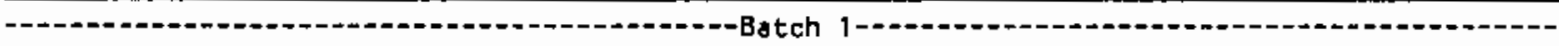 } \\
\hline $\begin{array}{r}\text { Control } \\
\text { Control } \\
108 \\
108 \\
1008 \\
1008\end{array}$ & $\begin{array}{l}0 \\
0 \\
0.58 \pm 0.02 \\
0.55 \pm 0.00 \\
5.22 \pm 0.10 \\
5.17 \pm 1.10\end{array}$ & $\begin{array}{l}2 / 10 \\
1 / 10 \\
1 / 10 \\
1 / 10 \\
1 / 10 \\
0 / 10\end{array}$ & $\begin{array}{r}158 \\
108 \\
58\end{array}$ & $\begin{array}{l}7.1 \\
7.0 \\
7.5 \\
7.4 \\
7.9 \\
7.5\end{array}$ \\
\hline \multicolumn{5}{|c|}{ 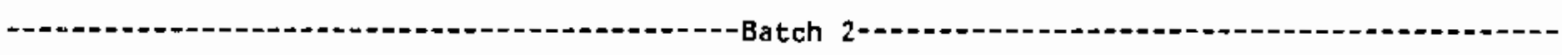 } \\
\hline $\begin{array}{r}\text { Control } \\
\text { Control } \\
108 \\
108 \\
1008 \\
1008\end{array}$ & $\begin{array}{l}0 \\
0.60 \pm 0.02 \\
0.69 \pm 0.04 \\
5.51 \pm 0.65 \\
5.87 \pm 0.87\end{array}$ & $\begin{array}{l}1 / 10 \\
0 / 10 \\
9 / 10 \\
0 / 10 \\
1 / 10 \\
0 / 10\end{array}$ & $\begin{array}{l}58 \\
08 \\
08\end{array}$ & $\begin{array}{l}7.6 \\
7.7 \\
7.6 \\
7.7 \\
7.4 \\
7.5\end{array}$ \\
\hline \multicolumn{5}{|c|}{ - } \\
\hline $\begin{array}{r}\text { Contrel } \\
\text { Contrel } \\
108 \\
1008 \\
108 \\
1008\end{array}$ & $\begin{array}{l}0 \\
0.32 \pm 0.01 \\
2.94 \pm 0.12 \\
0.35 \pm 0.02 \\
3.46 \pm 0.31\end{array}$ & $\begin{array}{l}0 / 10 \\
0 / 10 \\
0 / 10 \\
0 / 10 \\
0 / 10 \\
0 / 10\end{array}$ & $\begin{array}{l}0 \% \\
0 \% \\
0 \%\end{array}$ & $\begin{array}{l}7.4 \\
7.5 \\
7.6 \\
7.5 \\
7.8 \\
7.4\end{array}$ \\
\hline
\end{tabular}


TABLE 48. COMPARISON OF ALGAL TOXICITY OF THREE BATCHES OF SGF NO. 2 FOG OIL BASED ON THE 96-HR MEAN CELL COUNTS

\begin{tabular}{|c|c|c|c|c|c|c|c|c|}
\hline \multirow[b]{2}{*}{ Treatment } & \multicolumn{3}{|c|}{ Batch 1} & \multicolumn{3}{|c|}{ Batch 2} & \multicolumn{2}{|c|}{ Batch 3} \\
\hline & $\begin{array}{c}\text { Total } 031 \\
(\mathrm{mg} / \mathrm{L})\end{array}$ & Cell & $\begin{array}{l}\text { Mean } \\
\text { Counts }\end{array}$ & $\begin{array}{c}\text { Total } 0 \dagger 1 \\
(\mathrm{mg} / \mathrm{L})\end{array}$ & $\mathrm{CeIl}$ & $\begin{array}{l}\text { Mean } \\
\text { Counts }\end{array}$ & $\begin{array}{c}\text { Total oil } \\
(\mathrm{mg} / \mathrm{L})\end{array}$ & $\begin{array}{c}\text { Mean } \\
\text { Cell Counts } \\
\end{array}$ \\
\hline 1008 & 3.23 & 0.35 & $\pm 0.12(3)$ & 2.39 & 2.24 & $\pm 0.12(3)$ & 3.47 & $0.60 \neq 0.58 \quad(3)$ \\
\hline 608 & 2.15 & 0.63 & $\pm 0.10(3)$ & 1.44 & 2.58 & $\pm 0.16(3)$ & 2.75 & $0.82 \pm 0.72(3)$ \\
\hline 400 & 1.66 & 1.06 & $\pm 0.12(3)$ & 1.17 & 3.67 & $\pm 0.20(3)$ & 2.56 & $1.27 \pm 0.97(3)$ \\
\hline 208 & 0.95 & 1.04 & \pm 0.21 (3) & 0.65 & 2.75 & $\pm 1.27(3)$ & 1.07 & $1.06 \pm 0.75$ \\
\hline $10 \%$ & 0.67 & 1.28 & $\pm 0.44(3)$ & 0.45 & 3.85 & \pm 0.29 (3) & 0.61 & $1.10 \neq 0.78(3)$ \\
\hline $5 \%$ & $0.76 \mathrm{~b}$ & 1.10 & \pm 0.10 (3) & $0.29 \mathrm{~b}$ & 2.77 & \pm 0.76 (3) & $\mathrm{b}$ & Not Tested \\
\hline Control & $0.14^{\mathrm{D}}$ & 1.00 & $\pm 0.94(3)$ & $0.20^{\mathrm{D}}$ & 3.20 & $\pm 0.16(3)$ & $0.22^{\mathrm{D}}$ & $1.06 \pm 0.81$ \\
\hline
\end{tabular}

Cells $\times 10^{6} / \mathrm{mL} \pm 1.05 .0$. ( $n=$ sample size $)$.

background levels.

The ANOVA of the mean cell counts for Batch 1 fog oil showed significant interaction effects and effects over time, but treatment (fog oil concentration) effects were not significant (Table 49). At $96 \mathrm{hr}$, a posteriori multiple pairwise comparisons showed no significant differences between any pairs of means using Scheffe's critical value (Table 50). The Tess conservative tests (without Scheffe's correction) showed that the tw' highest exposure treatments ( $100 \%$ and $60 \%$ treatments) were significantly different from all other treatments, but were not different from each other $(p<0.1)$. The degree of growth inhibition in the high exposure was $65 \%$ compared to the controls.

TABLE 49. ANALYSIS OF VARIANCE (ANOVA) OF MEAN CELL COUNT DATA FROM THE ALGAL TOXICITY TEST WITH BATCH 2 FOG OIL

\begin{tabular}{|c|c|c|c|c|c|}
\hline Source & Sum of Squares & $\begin{array}{c}\text { Degrees of } \\
\text { Freedom }\end{array}$ & Mean Square & $F$ & $\begin{array}{l}\text { Tait } \\
\text { Prob. }\end{array}$ \\
\hline $\begin{array}{l}\text { Mean } \\
\text { Cell Counts } \\
\text { Error }\end{array}$ & $\begin{array}{r}4923122.84272 \\
462266.30184 \\
468482.22032\end{array}$ & $\begin{array}{r}1 \\
6 \\
13\end{array}$ & $\begin{array}{r}4923122.84272 \\
77044.38364 \\
36037.09387\end{array}$ & $\begin{array}{r}136.61 \\
2.14\end{array}$ & $\begin{array}{l}0.0000 \\
0.1182\end{array}$ \\
\hline $\begin{array}{l}\text { Time } \\
\text { Interaction } \\
\text { Error }\end{array}$ & $\begin{array}{r}11965023.79693 \\
1383690.53783 \\
1522338.13714\end{array}$ & $\begin{array}{r}4 \\
24 \\
52\end{array}$ & $\begin{array}{r}2991255.94923 \\
57653.77241 \\
29275.73341\end{array}$ & $\begin{array}{r}102.18 \\
1.97\end{array}$ & $\begin{array}{l}0.0000 \\
0.0208\end{array}$ \\
\hline
\end{tabular}


TABLE 50. F-VALUES FOR COMPARISONS BETWEEN ALL POSSIBLE PAIRS OF MEANS AT $0,24,48,72$, AND 96 HOURS FOR BATCH 1 FOG OIL

\begin{tabular}{|c|c|c|c|c|c|}
\hline $\begin{array}{l}\text { Treatment } \\
\text { Contrast }\end{array}$ & 0 Hours & 24 Hours & 48 Hours & 72 Hours & 96 Hours \\
\hline $100 \%-60 \%$ & 0.00 & 0.00 & 0.00 & 0.00 & 3.38 \\
\hline $100 \%-40 \%$ & 0.00 & 0.00 & 0.00 & 0.02 & 21.10 \\
\hline $100 \%-20 \%$ & 0.00 & 0.00 & 0.00 & 0.01 & 20.39 \\
\hline $100 \%-10 \%$ & 0.00 & 0.00 & 0.02 & 0.21 & 36.28 \\
\hline $100 \%-5 \%$ & 0.00 & 0.00 & 0.00 & 0.59 & 16.28 \\
\hline $100 \%$ - Control & 0.00 & 0.00 & 0.11 & 0.79 & 17.90 \\
\hline $60 \%-40 \%$ & 0.00 & 0.00 & 0.00 & 0.02 & 7.60 \\
\hline $60 \%-20 \%$ & 0.00 & 0.00 & 0.00 & 0.00 & 7.17 \\
\hline $60 \%-10 \%$ & 0.00 & 0.00 & 0.03 & 0.19 & 17.52 \\
\hline $60 \%-5 \%$ & 0.00 & 0.00 & 0.00 & 0.56 & 5.72 \\
\hline $60 \%$ - Control & 0.00 & 0.00 & 0.13 & 0.74 & 5.73 \\
\hline $40 \%-20 \%$ & 0.00 & 0.00 & 0.00 & 0.00 & 0.01 \\
\hline $40 \%-10 \%$ & 0.00 & 0.00 & 0.01 & 0.10 & 2.04 \\
\hline $40 \%-5 \%$ & 0.00 & 0.00 & 0.00 & 0.41 & 0.01 \\
\hline $40 \%$ - Control & 0.00 & 0.00 & 0.09 & 0.55 & 0.13 \\
\hline $20 \%-10 \%$ & 0.00 & 0.00 & 0.01 & 0.14 & 2.27 \\
\hline $20 \%-5 \%$ & 0.00 & 0.00 & 0.00 & 0.47 & 0.00 \\
\hline $20 \%$ - Control & 0.00 & 0.00 & 0.08 & 0.63 & 0.08 \\
\hline $10 \%-5 \%$ & 0.00 & 0.00 & 0.01 & 0.13 & 1.83 \\
\hline $10 \%$ - Control & 0.00 & 0.00 & 0.03 & 0.18 & 3.21 \\
\hline $5 \%$ - Control & 0.00 & 0.00 & 0.08 & 0.00 & 0.06 \\
\hline
\end{tabular}

The ANOVA for the Batch 2 test was significant for treatment, effects over time and interactions (Table 51). Tests with Scheffe's correction showed no significant differences between any treatment means (Table 52). The less conservative tests showed a number of differences at $P>0.05$. At 48 and $72 \mathrm{hr}$, the control response was different than the $100 \%, 60 \%$ and $5 \%$ treatments. At $96 \mathrm{hr}$, the control treatment was different than the $100 \%$, $40 \%$ and $10 \%$ treatments. The apparent degree of inhibition was approximately $40 \%$ in the $100 \%(2.24 \mathrm{mg} / \mathrm{L})$ treatment. Other tests among treatments at. $96 \mathrm{hr}$ were significant. These include the following: the $60 \%$ treatment was different than the $40 \%$ and $10 \%$ treatments, the $40 \%$ treatment was different than the $20 \%$ and $5 \%$ treatments, the $20 \%$ and $10 \%$ treatments were different, and the $10 \%$ and $5 \%$ treatments were different. These random fluctuations indicate the degree of variability in response observed at oil concentrations between 0.29 and $1.44 \mathrm{mg} / \mathrm{L}$. 
TABLE 51. ANALYSIS OF VARIANCE (ANOVA) OF MEAN CELL COUNT DATA FROM THE ALGAL TOXICITY TEST WITH BATCH 2 FOG OIL

\begin{tabular}{lrrrrr}
\hline \multicolumn{1}{c}{ Source } & Sum of Squares & $\begin{array}{c}\text { Degrees of } \\
\text { Freedom }\end{array}$ & Mean Square & F & $\begin{array}{r}\text { Tai1 } \\
\text { Prob. }\end{array}$ \\
\hline Mean & 173255083.72342 & 1 & 173255083.72342 & 1032.17 & 0.0000 \\
Cell Counts & 5697295.54964 & 6 & 949549.25827 & 5.66 & 0.0044 \\
Error & 2182117.23051 & 13 & 167855.17158 & & \\
& & & & & \\
Time & 109120756.46799 & 4 & 27280189.11700 & 299.77 & 0.0000 \\
Interaction & 6640780.00750 & 24 & 276699.16698 & 3.04 & 0.0004 \\
Error & 4732187.99545 & 52 & 91003.61530 & & \\
\hline
\end{tabular}

TABLE 52. F-VALUES FOR COMPARISONS BETWEEN ALL POSSIBLE PAIRS OF NEANS AT $0,24,48,72$, AND 96 HOURS FOR BATCH 2 FOG OIL

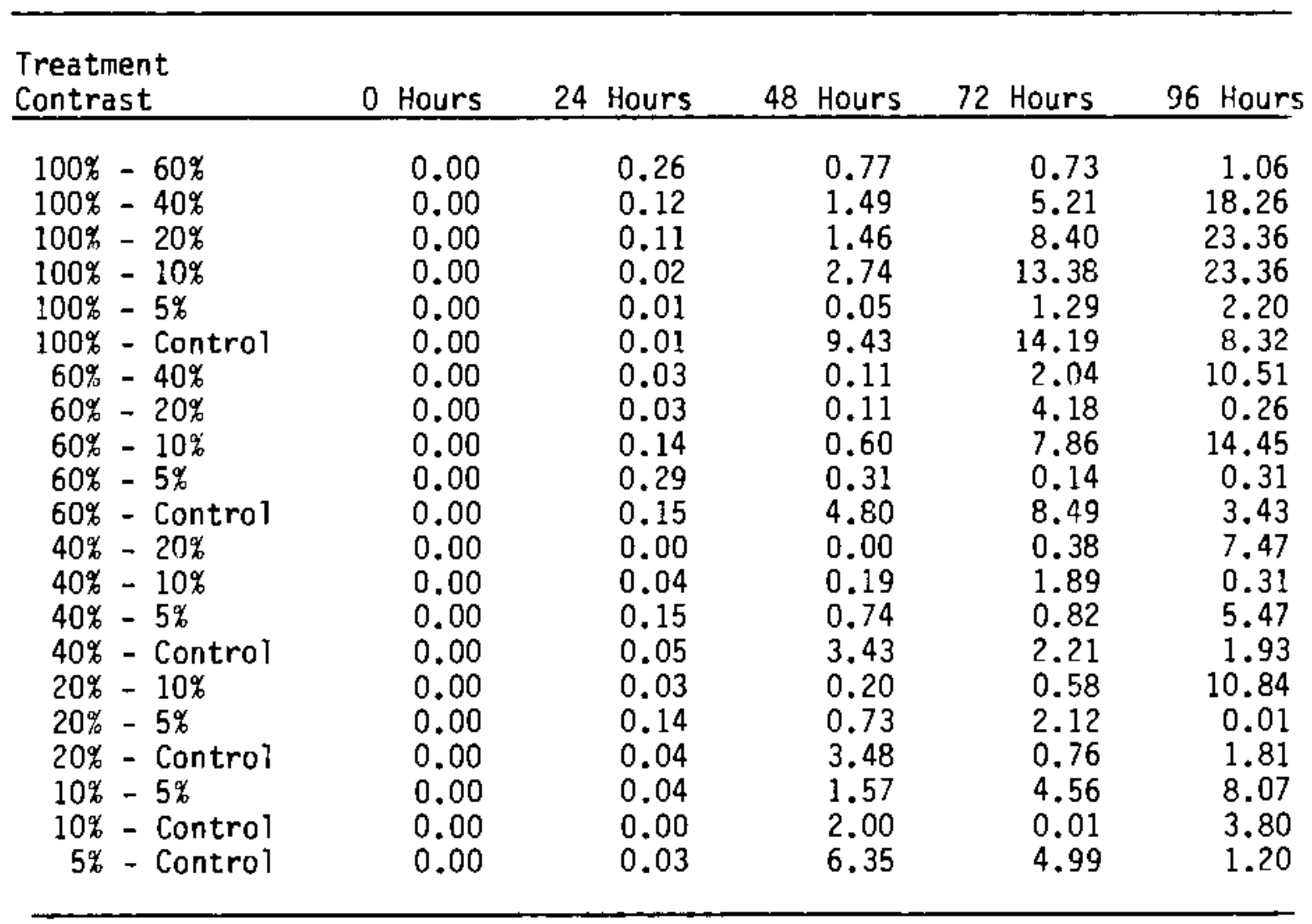


TABLE 53. ANALYSIS OF VARIANCE (ANOVA) OF MEAN CELL COUNT DATA FROM THE ALGAL TOXICITY TEST WITH BATCH 3 FOG OIL

\begin{tabular}{|c|c|c|c|c|c|}
\hline Source & Sum of Squares & $\begin{array}{c}\text { Degrees of } \\
\text { Freedom }\end{array}$ & Mean Square & $\mathbf{F}$ & $\begin{array}{l}\text { Tail } \\
\text { Prob. }\end{array}$ \\
\hline $\begin{array}{l}\text { Mean } \\
\text { Cell Counts } \\
\text { Error }\end{array}$ & $\begin{array}{r}6848585.38618 \\
143971.73991 \\
266866.15177\end{array}$ & $\begin{array}{r}1 \\
5 \\
11\end{array}$ & $\begin{array}{r}6848585.38618 \\
28794.34798 \\
24260.55925\end{array}$ & $\begin{array}{r}282.29 \\
1.19\end{array}$ & $\begin{array}{l}0.0000 \\
0.3758\end{array}$ \\
\hline $\begin{array}{l}\text { Time } \\
\text { Interaction } \\
\text { Error }\end{array}$ & $\begin{array}{r}11647756.33159 \\
707768.58784 \\
1023608.67128\end{array}$ & $\begin{array}{r}4 \\
20 \\
44\end{array}$ & $\begin{array}{r}2911939.08290 \\
35388.42939 \\
23263.83344\end{array}$ & $\begin{array}{r}125.17 \\
1.52\end{array}$ & $\begin{array}{l}0.0000 \\
0.1222\end{array}$ \\
\hline
\end{tabular}

The ANOVA of the Batch 3 test was not significant for treatment or interaction effects between time and treatment effects (Table 53). No further statistical comparisons of treatment means were conducted. Inspection of the data suggests $40 \%$ inhibition of growth at $96 \mathrm{hr}$ between the $3.47 \mathrm{mg} / \mathrm{L}$ treatment and the control treatment.

An algal toxicity test was performed with vaporized Batch 3 fog oil (F0-4). The ANOVA (Table 54) was not significant for treatment or interaction effects and no further testing was conducted. Inspection of the data (Table 55) suggests no indication of a dose dependent response.

As a result of the Phase II Screening toxicity tests, it was concluded that there was very little if any toxicity associated with fog $0 i l$. Moreover, there was no firm indication that one batch was more toxic than another. Batch 3 was selected for vaporization and photolys is studies because it was the most recently manufactured batch of fog 011 . By outward appearances, it was the least oxidized batch of oil. Acute toxicity tests were performed with bulk and vaporized Batch 3 fog $0 i$ with all four invertebrate spectes. $P$. promelas were also tested at a screening level with vaporized fog 011 . H. $\underline{\text { azteca }}$ was used in the photolysis experimerits.

The results of the D. magna tests with bulk and vaporized fog oil closely paralleled the phase Itests. The principle response was the phenomenon of floaters caused by adherence of fog oit to the organisms (Table 56). The stock solutions generated for these tests contained considerably more fog oil than prior tests. This was caused by a bend in the shaft of the stirring propelier which created greater mixing energies during the mix. As indicated in the Phase I tests, it was not possible to separate the toxic properties of the oil from the physical effects. Comparisons can be made where exposure concentrations overiap between the bulk and the vaporized fog oil. Initial exposure concentrations of 
TABLE 54. ANALYSIS OF VARIANCE (ANOVA) OF MEAN CELL COUNT DATA FROM THE ALGAL TOXICITY TEST WITH VAPORIZED BATCH 3 FOG OIL

\begin{tabular}{|c|c|c|c|c|c|}
\hline Source & Sum of Squares & $\begin{array}{c}\text { Degrees of } \\
\text { Freedom }\end{array}$ & Mean Square & $F$ & $\begin{array}{l}\text { Tail } \\
\text { Prob. }\end{array}$ \\
\hline $\begin{array}{l}\text { Mean } \\
\text { Cell Counts } \\
\text { Error }\end{array}$ & $\begin{array}{r}8566618.16565 \\
194390.07682 \\
270281.48659\end{array}$ & $\begin{array}{r}1 \\
5 \\
12\end{array}$ & $\begin{array}{r}8566618.16565 \\
38878.01536 \\
22523.45722\end{array}$ & $\begin{array}{r}380.34 \\
1.73\end{array}$ & $\begin{array}{l}0.0000 \\
0.2032\end{array}$ \\
\hline $\begin{array}{l}\text { Time } \\
\text { Interaction } \\
\text { Error }\end{array}$ & $\begin{array}{r}11932427.90291 \\
442194.85531 \\
796553.32236\end{array}$ & $\begin{array}{r}4 \\
20 \\
48\end{array}$ & $\begin{array}{r}2983106.97573 \\
22109.74277 \\
16594.86088\end{array}$ & $\begin{array}{r}179.76 \\
1.33\end{array}$ & $\begin{array}{l}0.0000 \\
0.2055\end{array}$ \\
\hline
\end{tabular}

vaporized fog oil were Tethal at $8.96 \mathrm{mg} / \mathrm{L}$ after $48 \mathrm{hr}$ (Table 57). The stock solution of the bulk fog $011(30.6 \mathrm{mg} / \mathrm{L})$ was $80 \%$ lethal at $48 \mathrm{hr}$ suggesting that vaporization had increased the toxicity of the fog oil. When it became apparent that the stock solutions had higher than expected levels of fog ofl, additional exposure beakers were set up at nominal concentrations of $1.0 \%$ and $0.1 \%$ of the stock solutions. These treatments provide an estimate of the amount of oil necessary to cause the floating response. Base on the results from the two tests, the concentration of fog oi] required to produce floaters is quite low, on the order of $\sim 0.10$ to $0.30 \mathrm{mg} / \mathrm{L}$ total $0 j 1$.

Biological endpoints monitored in the acute toxicity tests with P. dissimilus included mortality and the number of tubes constructed by the

TABLE 55. RESPONSES OF SELENASTRUM CAPRICORNUTUM TO VAPORIZED BATCH 3 FOG (96-HR DATA)

\begin{tabular}{ccc}
\hline Treatment & $\begin{array}{c}\text { Total } 0 \mathrm{jl} \\
(\mathrm{mg} / \mathrm{L})\end{array}$ & $\begin{array}{c}\text { Mean }( \pm 1.0 \mathrm{~S} . \mathrm{D} .) \text { Celi } \\
\text { Counts }\left(\times 10^{6} / \mathrm{mL}\right)\end{array}$ \\
\hline & & \\
$100 \%$ & $2.38 \pm 0.07$ & $0.83 \pm 0.16$ \\
$60 \%$ & $1.48 \pm 0.06$ & $1.02 \pm 0.60$ \\
$40 \%$ & $1.10 \pm 0.09$ & $0.95 \pm 0.36$ \\
$20 \%$ & $0.76 \pm 0.07$ & $0.97 \pm 0.17$ \\
$10 \%$ & $0.68 \pm 0.00$ & $1.35 \pm 0.04$ \\
$0 \%$ & $0.18 \pm 0.02$ & $0.84 \pm 0.10$ \\
\hline
\end{tabular}


TABLE 56. OBSERVATIONS ( $\%$ ) OF DAPHNIA MAGNA EXPOSED TO OWM OF BATCH 3 BULK FOG OIL

\begin{tabular}{|c|c|c|c|c|c|c|c|c|}
\hline \multirow[b]{3}{*}{ Ireatment } & \multirow{3}{*}{$\begin{array}{c}\text { Total } 0 \mathrm{i} 1 \\
(\mathrm{mg} / \mathrm{L}) \\
\end{array}$} & \multirow{3}{*}{$\begin{array}{c}\text { No. of } \\
\text { Organism }\end{array}$} & \multicolumn{3}{|c|}{$24 \mathrm{hr}$} & \multicolumn{3}{|c|}{$48 \mathrm{hr}$} \\
\hline & & & \multicolumn{2}{|c|}{ Floaters } & \multirow{2}{*}{$\frac{\text { Free }}{\text { Swimming (\$) }}$} & \multicolumn{2}{|c|}{ Floaters } & \multirow{2}{*}{$\frac{\text { Free }}{\text { Swiming (8) }}$} \\
\hline & & & Alive (8) & Dead (8) & & Alive (n) & Dead (8) & \\
\hline $\begin{array}{c}100 \% \\
60 \% \\
40 \% \\
208 \\
108 \\
1 \% \\
0.18 \\
\text { Control }\end{array}$ & $\begin{array}{l}30.63 \pm 0.65 \\
16.99 \pm 1.12 \\
12.43 \pm 0.47 \\
6.26 \pm 0.12 \\
3.60 \pm 0.13 \\
(0.30)^{\mathrm{b}} \mathrm{b} \\
(0.03)^{\mathrm{b}} \\
0.16 \text { (Bkg) }\end{array}$ & $\begin{array}{l}20 \\
20 \\
19 \\
19 \\
20 \\
20 \\
20 \\
20\end{array}$ & $\begin{array}{r}50 \\
65 \\
42 \\
89 \\
90 \\
85 \\
80 \\
0\end{array}$ & $\begin{array}{r}45 \\
35 \\
58 \\
11 \\
10 \\
0 \\
5 \\
0\end{array}$ & $\begin{array}{r}0^{a} \\
0 \\
0 \\
0 \\
0 \\
15 \\
15 \\
100\end{array}$ & $\begin{array}{r}20 \\
35 \\
11 \\
50 \\
55 \\
55 \\
55 \\
0\end{array}$ & $\begin{array}{l}80^{a} \\
65 \\
89 \\
50 \\
45 \\
35^{a} \\
35 \\
0\end{array}$ & $\begin{array}{c}0^{a} \\
0 \\
0 \\
0 \\
0 \\
10 \\
10 \\
100\end{array}$ \\
\hline
\end{tabular}

One dead organism on bottom of beaker.

b Nominal concentration based on dilution of stock solution.

TABLE 57. OBSERVATIONS OF DAPHNIA MAGNA EXPOSED TO OWM OF BATCH 3 VAPORIZED FOG OIL

\begin{tabular}{|c|c|c|c|c|c|c|c|}
\hline \multirow[b]{3}{*}{ Ireatment } & \multirow{3}{*}{$\begin{array}{r}\text { Total } 0 j 1 \\
(\mathrm{mg} / \mathrm{L}) \\
\end{array}$} & \multicolumn{3}{|c|}{$24 \mathrm{hr}$} & \multicolumn{3}{|c|}{$48 \mathrm{hr}$} \\
\hline & & \multicolumn{2}{|c|}{ Floaters } & \multirow{2}{*}{$\frac{\text { Free }}{\text { Swiming (8) }}$} & \multicolumn{2}{|c|}{ Floaters } & \multirow{2}{*}{$\frac{\text { Free }}{\text { Swiming }(s)}$} \\
\hline & & Alive (8) & Dead (\%) & & Alive (8) & Dead (8) & \\
\hline $\begin{array}{c}1008 \\
608 \\
408 \\
208 \\
108 \\
18 \\
0.18 \\
\text { Control }\end{array}$ & $\begin{array}{c}71.95 \pm 3.27 \\
46.17 \pm 4.59 \\
33.59 \pm 3.00 \\
17.16 \pm 0.66 \\
8.96 \pm 8.16 \\
(0.72)^{8} \\
(0.072) \\
0.08 \pm 0.08\end{array}$ & $\begin{array}{r}80 \\
100 \\
100 \\
100 \\
100 \\
94 \\
100 \\
0\end{array}$ & $\begin{array}{r}20 \\
0 \\
0 \\
0 \\
0 \\
0 \\
0 \\
0\end{array}$ & $\begin{array}{r}0 \\
0 \\
0 \\
0 \\
0 \\
0 \\
0 \\
100\end{array}$ & $\begin{array}{c}0 \\
0 \\
0 \\
0 \\
0 \\
17 \\
25^{\mathrm{c}}\end{array}$ & $\begin{array}{c}100 \\
100 \\
100 \\
100 \\
100 \mathrm{~b} \\
78^{b} \\
65 \\
0\end{array}$ & $\begin{array}{r}0 \\
0 \\
0 \\
0 \\
0 \\
0 \\
0 \\
100\end{array}$ \\
\hline
\end{tabular}

Nominal concentrations.

c One handling mortality on 18 total organisms for this treatment.

Two free swimming organisms. 
Tarvae (Table 58). Mortality was a difficult parameter to measure because in many instances the larvae would not move once they were located in the test beakers and removed for quantification. Mortality at $48 \mathrm{hr}$ in the vaporized and bulk fog 0 il tests didn't exceed $50 \%$ in spite of the fact that the stock solutions used for these tests were considerabiy more concentrated than those use in the Phase II screening tests. In contrast with the D. magna tests, bulk fog oil appeared to be more toxic than vaporized fog oil. Decreases in tube building in both tests were indicative of adverse effects of the fog oil but were not statisticaliy analyzed. The number of tubes constructed as well as the length of the tubes decreased with increasing fog $0 i l$ concentration. Mortality and tube construction were noticeably effected at approximately 12 to $17 \mathrm{mg} / \mathrm{L}$ total 01 . It is not known what effect, if any, the presence of substrate had on the toxicity of the oil.

In the course of performing the planned Phase II tests and the photolysis tests, several tests were performed with bulk and vaporized batch 3 fog $0 i j$ and $H$. azteca. Screening tests with Batch 3 bulk fog oil indicated that $14.8 \mathrm{mg} /[$ total $0 i 1$ was not acutely toxic to $\mathrm{H}$. azteca (Table 59). A screening test with vaporized fog oil indicated that vaporization had 7ittle effect on toxicity. A Phase II test with vaporized fog oil had only five percent mortality at $48 \mathrm{hr}$ in the highest concentration tested

TABLE 58. EXPOSURE OF PARATANYTARSUS DISSIMILUS TO OWM OF BULK AND VAPORIZED BATCH 3 FOG OIL

\begin{tabular}{|c|c|c|c|c|}
\hline Treatment & $\begin{array}{c}\text { Totat } 0 j 1 \\
(\mathrm{mg} / \mathrm{L}) \\
\end{array}$ & Number & Mortality (\%) & No. of Tubes \\
\hline $\begin{array}{r}100 \% \\
60 \% \\
40 \% \\
20 \% \\
10 \% \\
\text { Control }\end{array}$ & $\begin{array}{r}30.63 \pm 0.65 \\
16.99 \pm 1.12 \\
12.43 \pm 0.47 \\
6.26 \pm 0.12 \\
3.60 \pm 0.13 \\
<0.16\end{array}$ & $\begin{array}{l}20 \\
19 \\
20 \\
19 \\
19 \\
20\end{array}$ & $\begin{array}{r}25 \\
26 \\
5 \\
10 \\
20 \\
0\end{array}$ & $\begin{array}{r}0 \\
6 \\
14 \\
18 \\
13 \\
25\end{array}$ \\
\hline $\begin{array}{r}100 \% \\
60 \% \\
40 \% \\
20 \% \\
10 \% \\
\text { Control }\end{array}$ & $\begin{array}{r}71.95 \pm 3.27 \\
46.17 \pm 4.59 \\
33.59 \pm 3.00 \\
17.16 \pm 0.66 \\
8.96 \pm 0.16 \\
0.08 \pm 0.08\end{array}$ & $\begin{array}{l}20 \\
20 \\
19 \\
20 \\
20 \\
20\end{array}$ & $\begin{array}{r}35 \\
30 \\
11 \\
5 \\
0 \\
0\end{array}$ & $\begin{array}{r}1 \\
4 \\
2 \\
12 \\
24 \\
31\end{array}$ \\
\hline
\end{tabular}


TABLE 59. SUMMARY OF HYALLELA AZTECA MORTALITY $(\%)$ IN SCREENING TOXICITY TEST WITH PHOTOLYZED BATCHES OF BULK AND VAPORIZED FOG OIL

$24 \mathrm{hr}$

$48 \mathrm{hr}$

Bulk $0 i 1$

$100 \%$ stock $(14.8 \mathrm{mg} / \mathrm{L})^{b}$

$20 \%$ stock

Control

$\begin{array}{ll}0 & 6 \\ 0 & 0 \\ 0 & 6\end{array}$

Photolyzed Bulk oil

$\begin{array}{lrr}100 \% \text { stock }(66.3 \mathrm{mg} / \mathrm{L})^{\mathrm{b}} & 25 & 100 \\ 20 \% \text { stock } & 0 & 0 \\ \text { Control } & 6 & 6 \\ & & \\ & & \\ 100 \% \text { stock }(64.3 \mathrm{mg} / \mathrm{L})^{\mathrm{b}} & 13 & 25 \\ 20 \% \text { stock } & 0 & 0 \\ \text { Control } & 0 & 0\end{array}$

\begin{tabular}{lrr} 
& & \\
$100 \%$ stock $(188 \mathrm{mg} / \mathrm{L})^{b}$ & 100 & 100 \\
$20 \%$ stock & 25 & 63 \\
Control & 6 & 6 \\
\hline
\end{tabular}

a sixteen organisms per treatment.

By IR analysis.

$(5.58 \mathrm{mg} / \mathrm{L}$ total $0 i 1)$. As in other tests with bulk and vaporized fog oil, the exposire solutions in these tests had oil slicks floating on the surface of the exposure solutions at $24 \mathrm{hr}$. Because total mortality didn't exceed $50 \%$, EC50 values were not calculated.

Photolysis of Fog $0 i 1$

Four screening-level toxicity tests were performed with $\mathrm{H}$. azteca as the test species. Four treatments of Batch $3 \mathrm{SGF}$ No. 2 Fog $0 \bar{i}$ were used in tests: bulk fog oil (untreated), vaporized fog oil (F0-4), and 24-hr photolyzed treatments of both. The photolyzed and non-photolyzed oil were tested $\sim 5$ to 6 days after photolysis.

The mortality data from all four tests are summarized in Table 59 . It is readily apparent that toxicity of the bulk fog oil had not noticeably 
TABLE 60. TOXICITY TESTING RESULTS OF HYALLELA AZTECA AND BULK FOG OIL, 7-DAY PHOTOLYZED BULK FOG OIL, VAPORIZEDD FOG OIL, AND PHOTOLYZED-VAPORIZED FOG OIL

\begin{tabular}{|c|c|c|c|}
\hline \multirow[b]{2}{*}{ Treatment } & \multirow{2}{*}{$\begin{array}{c}\text { TotaI } 0 i 1^{a} \\
(\mathrm{mg} / \mathrm{L})\end{array}$} & \multicolumn{2}{|c|}{ Mortality $(8, n=15)$} \\
\hline & & $24 \mathrm{hr}$ & $48 \mathrm{hr}$ \\
\hline$\cdots$ & 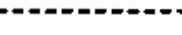 & - & 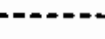 \\
\hline $\begin{array}{r}100 \% \\
20 \%\end{array}$ & $\begin{array}{c}2.02 \\
(0.40)\end{array}$ & $\begin{array}{l}0 \\
0\end{array}$ & $\begin{array}{l}0 \\
0\end{array}$ \\
\hline $\begin{array}{l}100 \% \\
60 \% \\
40 \% \\
208 \\
108 \\
\text { Control }\end{array}$ & $\begin{array}{c}18.52 \\
(19.1) \\
(7.4) \\
(3.7) \\
(1.9) \\
0\end{array}$ & $\begin{array}{r}40 \\
0 \\
7 \\
0 \\
0 \\
0\end{array}$ & $\begin{array}{c}93 \\
38^{\mathrm{b}} \\
7 \\
7 \\
0 \\
0\end{array}$ \\
\hline $\begin{array}{c}1008 \\
208\end{array}$ & $\begin{array}{r}7.81 \\
(1.6)\end{array}$ & $\begin{array}{l}0 \\
0\end{array}$ & $\begin{array}{l}\cdots- \\
0\end{array}$ \\
\hline - - - - - & -.-.Phots & -- & --- \\
\hline $\begin{array}{c}100 \% \\
60 \% \\
40 \% \\
20 \% \\
10 \% \\
\text { Control }\end{array}$ & $\begin{array}{c}20.81 \\
(12.5) \\
(8.3) \\
(4.2) \\
(2.1) \\
0\end{array}$ & $\begin{array}{r}60 \\
20 \\
7 \\
0 \\
0 \\
0\end{array}$ & $\begin{array}{r}93 \\
60 \\
7 \\
0 \\
7 \\
0\end{array}$ \\
\hline
\end{tabular}

By UV adsorbence with isooctane extracts, nominal concentrations are in parentheses.

b $=13$.

TABLE 61. PETESTING OF 100\% EXPOSURE SOLUTIONS OF 7-DAY PHOTOLYZED FOG OIL

\begin{tabular}{lccc}
\hline \multicolumn{1}{c}{ Treatment } & $\begin{array}{c}\text { Total } 0 \mathrm{ij}^{\mathrm{a}} \\
(\mathrm{mg} / \mathrm{L})\end{array}$ & \multicolumn{2}{c}{ Mortality $(\%, \mathrm{n}=15)$} \\
\hline Photolyzed Bulk & 12.7 & $24 \mathrm{hr}$ & $48 \mathrm{hr}$ \\
Photolyzed-Vaporized & 16.7 & 27 & $93^{\mathrm{b}}$ \\
Control & 0 & 0 & $87^{\mathrm{b}}$ \\
& & & 0 \\
\hline
\end{tabular}

ay UV adsorbence, isooctane extracts.

b ATl living organisms were severely incapacitated. 
changed. In spite of higher oil concentrations than observed with the standard slow mix, the organisms did not become mired in the surface oil slicks. After $48 \mathrm{hr}$, only 1 of 16 organisms exposed to the $100 \%$ exposure solution had died. There were no mortalities in the $20 \%$ or control

treatments. The mortality pattern in the test with vaporized fog oil, however, indicated a higher level of mortality than was observed in the Phase II test with the standard slow mix. This may be explained by the higher level of fog oil in the exposure beakers.

Toxicity tests with $\mathrm{H}$. azteca were performed with batches of bulk and vaporized (FO-4) SGF No. $\overline{2}$ fog ofl that had been photolyzed for 7 days. The mixing regimen was modified because the method used for the screening tests with 24-hr photolyzed fog oil was considered to be too variable for standardization (see section 2.6.5). Only 100\% and $20 \%$ exposure solutions of unphotolyzed bulk and vaporized fog oils were prepared from these mixes. At the end of the test, the $100 \%$ photolyzed solutions were retested. This involved separating the aqueous phase from the photolyzed oil residues floating on the surface by siphoning under low vacuum. This was done to each of three replicate beakers for the $100 \%$ exposure solutions of the photolyzed bulk and vaporized fog oil. The non-photolyzed bulk and vaporized oils were not tested because they did not show any toxicity in the initial test.

As noted in the first tests with 24-hr photolyzed 017 , a major effect of photolysis on fog $0 i 1$ is the apparent increase in the ability of the oil to mix with water. The $100 \%$ stock solutions of photolyzed oils were approximately 2 to 20 times higher in total oil than the unphotolyzed oils (Table 60). A direct comparison of the $10 \%$ solutions of photolyzed bulk oils with the $100 \%$ solutions of the unphotolyzed bulk fog oils can be made on the basis of total oil concentrations. No mortality was noted in any of these treatments. The $100 \%$ and $60 \%$ solutions of both photolyzed oils were clearly toxic. The second series of tests with the siphoned fraction clearly showed that the toxic constituents remained in solution and did not separate out of solution (Table 61). The observed toxicity may be attributed to the higher concentrations of 0 il in water or an increase in the toxic character of the constituents of the photolyzed fog oil. In either case, photolysis increased the toxicity of SGF No. 2 fog oil. Moreover, the observed toxicity is most likely attributed to increased solubility of fog oil hydrocarbons. 


\subsection{DISCUSSION}

This chapter integrates those aspects of aerosol generation, chemistry and toxicity testing necessary to evaluate the environmental hazards of RP-BR and WP-F and fog oil obscurants to aquatic organisms. The effect acidification has on the toxicity of phosphorus-based obscurants is also discussed. Toxicity testing with fog oil indicated that the obscurants were relatively non-toxic and that fouling caused by direct contact with oil is the primary concern. Photolysis was shown to increase the presence of soluble components in the oil and the resulting toxicity. Issues that need to be considered when attempting to extrapolate these laboratory data to field exposure situations are discussed at the end of the chapter.

\subsection{PHOSPHORUS-BASED CBSCURANTS}

This section discusses aerosol generation, chemistry, and toxicity of RP-BR and WP-F. Phase I tests determined the effects of aging and neutralization on the chemistry and toxicity of these materials in water. The Phase II tests provided definitive information on how total $P$ and $\mathrm{pH}$ affect the toxicity of oil. Results of the Phase I tests are compared with published data on the tolerance of aquatic organisms to toxicity and acidification.

\subsubsection{Aerosol Generation}

Suitable methods for dosing water with RP-BR and WP-F smoke were developed in Phase I of the project. Initially, both bubbling and settling methods were tested; both were found to influence the percentage of phosphate and phosphite in the stock solutions. Settling of smoke on water was judged to be more representative of field conditions and, therefore, all subsequent dosing of exposure water used settling in either $54-$ or $760-\mathrm{L}$ carboys.

The lack of agreement between mean smoke concentration and total $P$ in the stock solutions in the 54-L carboy dosing system remains unresolved. Phosphorus combustion products are hygroscopic and retain an unknown amount of $\mathrm{H}_{2} \mathrm{O}$ after desiccation. Filter pad weights taken during smoke generation would overestimate the $P$ content of the smoke. Ash from the matrix materials may also inflate the measured concentrations of smoke, though this source is considered to be negligible. Incomplete settling of smoke prior to rinsing may have contributed to the lower-than-expected concentrations of $P$ in the stock solutions, but a 1.5-L filter grab sample taken from a 54-L carboy one hour after settling was negative. Therefore, it is reasonable to assume that settiing was at least $99 \%$ complete at the time stock

solutions were removed from the carboys. It is also possible that handling the carboys while rinsing could have resuspended some of the aerosol. Based on the reported solubilities of the various oxyphosphoric acids, 
incomplete dissolution and adherence to the sides of the carboys is unlikely.

It is possible that the geometry of the carboys and the temperature differentials between the smoke and the surfaces of the carboy, and between the smoke and the water in the carboy created convection currents that minimized the settling and sorbtion of smoke particles in the system. This does not account for the low recovery of mean smoke concentrations, however. Resolution of this discrepancy would require extensive mcdeling of aerosol dynamics within the carboys and is beyond the scope of the project. Although the relationship between total $P$ in the stock solutions and the mean smoke concentration in the $760-\mathrm{L}$ carboys agreed with what was expected (i.e., the concentration of $P$ in the stock solution exceeded the mean smoke concentration), uncertainties in the smaller carboy system cast doubt on the validity of these numbers. The discrepancy may be, in part, attributed to unremovable water bound to the smoke particles by hygroscopic forces; analysis for total $P$ or the filters was not included in the analysis regimen.

\subsubsection{Aqueous Chemistry}

Chemical changes in the smoke before and after entry into water may influence the speciation and degree of acidification of the receiving water. These changes, in turn, influence the resulting toxicity. Combustion of RP-BR or WP-F obscurants yields phosphorus oxides ranging up to the pentoxide $\left(\mathrm{P}_{4} \mathrm{O}_{10}\right)$ if combustion is complete. Lower oxides such as the trioxide $\left(\mathrm{P}_{4} \mathrm{O}_{6}\right)$ are enhanced when oxygen is limited. Upon contact with water, the oxides form acidic species, including linear polyphosphates and small amounts of cyclic metaphosphates. The polymers will eventually break down to form phosphoric acid, but reaction rates vary and total hydrolysis is slow. The trioxide also provides a potential pathway for formation of the highly toxic phosphine gas $\left(\mathrm{PH}_{3}\right)$. This gas has low water solubility and presents a minimal potential for aquatic toxicity.

Stock solutions were characterized routinely for total $P$ and for percentages as phosphate and phosphite to give an indication of the reproducibility of the dosing methodology. Selected samples were further speciated for polyphosphate distribution. Analysis for hypophosphite generally showed levels near or below detection limits, which would account for no more than $0.1 \%$ of the total phosphorus in solution. Phosphite levels, al though low, were more easlly measured. Although the initial bubbled RP-BR smoke test (RP-1) resulted in elevated (2.5\%) phosphite levels, all subsequent ievels were lower, usually running well below $1 \%$ for RP-BR burns and about $0.1 \%$ for WP $\rightarrow$ burns. Phosphate levels ranged from $8 \%$ to $20 \%$ in fresh solutions from 54-L carboy dosings. The large (760-L) fusion carboy containers used to generate smoke-dosed waters for fish studies ranged from $15 \%$ to $40 \%$ initial $\mathrm{PO}_{4}-\mathrm{P}$. Part of the variation may have been caused by the change in settling time allowed by the dosing methods. 
Although the toxicity tests were relatively short ( $s 96 \mathrm{hr}$ ), aging of the solutions over a 26-day period prior to exposure with Daphnia magna did point out the concentration/pH dependence on hydrolysis rate and solubitity of $P$ species in well water. The critical level at which precipitation occurred was about $\mathrm{pH} \mathrm{6;} \mathrm{neutralization} \mathrm{of} \mathrm{exposure} \mathrm{solutions} \mathrm{tended} \mathrm{to}$ result in more rapid inftial precipitation, followed by a long-term period of slow precipitation. Very hard waters tended to precipitate even without neutralization; the inherent alkalinity of the water caused partial neutralization of the acidic species. Although the precipitated material was not fully characterized, it could include components such as amorphous particles of alkaline earths and/or mixed salts of tripolyphosphates and pentapolyphosphates (Van Wazer 1958).

Speciation studies done after the program was well under way indicated that neutralization of fresh stock solutions apparently caused a change in the hydrolysis pathway or in rates of hydrolysis steps. Aged neutralized solutions tended to show elevated levels of cyclic trimetaphosphate relative to unneutralized solutions. The observed phosphate levels gave little indication of this change in hydrolysis. A rate-detemining step in overall hydrolysis may involve the $3 \mathrm{P}$ and/or $3 \mathrm{mP}$ species.

\subsubsection{Aquatic Toxicity}

The acute toxicity of RP-BR and WP-F smoke to nine different aquatic organisms was determined. Tests with D. magna during Phase $I$ of the project were extended from 48 to $96 \mathrm{hr}$. These extended tests revealed a bimodal response in smoke-dosed well water. The initial response was related to acidification of the exposure water and was readily apparent within 24 to $48 \mathrm{hr}$ of exposure. At 72 and $96 \mathrm{hr}$, a second phase of mortality was observed in the treatment containing $30 \%$ to $50 \%$ stock solution. This phase of mortality may have been related to the formation of precipitated material that accumulated in the gastrointestinal (GI) tract of the exposed daphnia. The extent to which materials would accumulate under field situations is unclear. In laboratory situations, the confines of an exposure beaker increase the interaction of the test organisms with the precipitated material. In field situations, the precipitated material is no longer available after it settles into the sediment. The significance of ingestion of precipitated material depends on whether the cause of death was due to functional blockage of the GI tract, chemical toxicjty, or a combination of the two factors. This secondary mode of toxicity may have little ecological significance.

The aging tests with D. magna in well water showed that exposure solutions below a pH of 5 changed Tittle in toxicity over time. The secondary toxicity related to precipitated material disappeared at 26 to 28 days. This observation corroborates our conclusion that the precipitated material is of little ecological significance. The potential for different aquatic systems to recover from acidification defines the long-term hazards associated with these materials. Acutely toxic effects would continue until 
natural or artificial processes elevate the $\mathrm{pH}$. The neutralization tests with reconstituted water indicated presence of toxic smoke constituent $(\mathrm{s})$ that acted independently of $\mathrm{pH}$. This phenomenon was apparent in Phase I tests with D. magna and in Phase II tests with Selenastrum capricornutum. Toxicity was only observed in the most concentrated solutions tested. A potential hazard to aquatic systems exists when sufficient amounts of smoke enter highly buffered water. The high buffering capacity negates pHorelated toxicity but allows levels of unidentified toxic constituents to accumulate.

Although red phosphorus is insoluble in water, white phosphorus shows measurable solubility at about $3 \mathrm{mg} / \mathrm{L}$ (Berkowitz et al. 1981) and, therefore, could present a significant mode of toxicity to freshwater organisms. The concentration of dissolved white phosphorus in severa? stock solutions was andyzed by solvent extraction and ICP analysis. In most cases, the concentrations were near or below detection limits and appeared to represent no more than $0.01 \%$ of the total $P$ in solution. While this level would be toxic to the more sensitive fish in a $20 \mathrm{mg} / \mathrm{L}$ total $P$ solution, the major source of toxicity remains the $\mathrm{pH}$ of the resultant solution. Toxicity in neutralized exposure solutions was observed only in neutralized solutions in excess of $70 \mathrm{mg} / \mathrm{L}$ total $P$.

Since WP-F toxicity to fish was reported to be on the order of $2 \mu \mathrm{g} / \mathrm{L}$ (Sullivan et al. 1979; Berkowitz et al. 1981), this level could be significant in a $20 \mathrm{mg} / L$ total $P$ solution. The EPA recommended limit for total $P$ in marine or estuarine water is $0.1 \mu \mathrm{g} / \mathrm{L}$ (Environmental Protection Agency 1976). The recommended discharge standard is $0.01 \mu \mathrm{g} / \mathrm{L}$ (Läi 1979). Actual analysis for $\mu \mathrm{g} / \mathrm{L}$ levels of WP-F would require the minimum of a GC procedure, which was not available for this study. Since the acid effect on the smoke-dosed water was the major source of toxicity in this study, neutralization of solutions would be the only method that could indicate any increased toxicity caused by the possible presence of dissolved elemental $P$ or specffic combustion products.

Acute toxicity of RP-BR and WP-F combustion products in water was directly related to the amount of acid generated from these materials. The extent to which a body of water will be acidified is a function of the buffering capacity of that water, the amount of smoke that enters the water, and the composition of the smoke. The $\mathrm{pH}$ of most freshwater systems is moderated by the amount of carbonate present in the system. The carbonate buffering system affords the highest degree of buffering about the pKa values of 6.43 at $15^{\circ} \mathrm{C}$ (i.e., a pH range of 5.4 to 7.4 ). The addition of oxy-phosphoric acids to the system also introduces a second major buffering system, that formed by the presence of dj-and mono-basic phosphates. The respective pka values for these phosphoric acid species are 7.21 and 2.12. Collectively, the carbonate and phosphoric acid buffering systems offer iittle buffering capacity at $\mathrm{pH}$ values between 3.0 and 5.4 . The larger polyphosphates may also contribute to the buffering capacity of the receiving water. Collectively, these anions contribute to the $\mathrm{pH}$ of the 
receiving water. The variable composition of the smoke and our lack of understanding of how the different phosphate species contribute to the buffering capacity of the water contributes to the variability between $\mathrm{pH}$ and total $P$ observed in the stock solutions used for toxicity testing.

The lack of buffering capacity between $\mathrm{pH}$ values of 3.0 and 5.4 affected the test methodology. This region of low buffering capacity overlaps the range of $\mathrm{pH}$ values that were acutely toxic. When concentrated stock solutions were used, small errors in the preparation of exposure solutions caused significant changes in the resulting $\mathrm{pH}$ of the exposure solutions. This made it difficult to obtain a range of $\mathrm{pH}$ levels in which there would be partial mortality. Moreover, a narrow range of $\mathrm{pH}$ values bracketed $100 \%$ mortality and 100\% survival in the tests with fish and invertebrates. In tests with no partial mortality, the confidence intervals about the LC50 cannot be estimated. These LC50 values agree with published accounts (discussed Tater) of the toxicity associated with acidification.

The toxicity tests with $S$. capricornutum need to be evaluated from the perspective of $\mathrm{pH}$ because algae media has a Tower buffering capacity than most surface bodies of water. Use of total $P$ as an indication of toxicity could inadvertently bias the assessment if the buffering potential of the media is not considered. The results of the algal toxicity test with WP-F were highly variable within treatments. This variation may be attributed to the inoculation level of $10,000 \mathrm{cell} / \mathrm{s} / \mathrm{mL}$ and to the use of three replicate flasks for each treatment. A higher inoculum level and additional flasks per treatment could have reduced the variability. The trends in the WP-F test were not significant but paralleled the trends in the RP-BR test, which were significant.

The toxicity tests indicated that algal growth was inhibited at $\mathrm{pH}$ levels $\leq 6.0$ and stimulated at $\mathrm{pH}$ levels $>6.0$. Suppression of growth was also observed in the algal stimulation tests at $\mathrm{pH} \sim 5.5$. Miller, Greene and Shiroyama (1978) reported appreciable growth in 14-day maximum yield tests at an initial pH of 5.0. Growth in flasks with an initial pH of 5 sustained approximately $90 \%$ of the growth in flasks at an initial pH of 6 to 9 over 14 days. Growth at $96 \mathrm{hr}$ was not reported. It is reasonable to assume that the $\mathrm{pH}$ levels would change over the 14-day period of the test and that growth at 4 days could have indicated a significantly different relationship to $\mathrm{pH}$. Photosynthes is increases $\mathrm{pH}$ levels by removing $\mathrm{CO}_{2}$ and shifting the bicarbonate equilibrium during the light cycle. Consequently, the data of Miller, Greene and Shiroyama (1978) and the data from our toxicity tests cannot be compared directly.

Stimulation of algal growth by phosphorus smoke was demonstrated at low smoke concentrations that did not acidify the media. The final concentration of $\mathrm{PO}_{4}$ was saturating in both neutralized and non-neutralized treatments. Because of the low buffering capacity of the algal media, the amounts of total $\mathrm{P}$ compared to $\mathrm{pH}$ are relatively small with respect to other types of water dosed in this project. Most green algae require 
between 0.02 and $0.50 \mathrm{mg} P 03 \mathrm{Z} / \mathrm{L}$ for optimal growth (Wetzel 1975). Bluegreen algae require higher concentrations of $P 03_{4}^{3}$, up to $3.00 \mathrm{mg} \mathrm{P03}=\mathrm{P} / \mathrm{L}$. It is apparent that small amounts of smoke entering a body of water could significantly affect algal growth before changes in $\mathrm{pH}$ would become perceptible. The potential for continued simulation of algal growth depends on the rate of hydrolysis of the longer chain polyphosphates and the blogeochemical cycling of $\mathrm{P}$ and other nutrients in the system.

The hazards presented by the introduction of the combustion products of phosphorus-based obscurants into aquatic systems are similar to the hazards presented by acid rain. It has been recommended that a criterion for the degree of acidification capable of adversely affecting aquatic habitats be lowered to a pH range from 5.0 to 6.0 (HenIrey 1984). This recommendation is founded upon a growing body of data from fieid studies of lakes influenced by acid precipitation. All major categories of freshwater life, including fish, invertebrates, and algal and microbial communities, are affected at $\mathrm{pH}$ levels below 6.0 .

Fish

Numerous studies have been perfonmed to define the sensitivity of fish to acid-induced stress. Ellgaard and Gilmore (1984) reported the 96-hr LC50 values of four reagent grade acids to bluegill sunfish. The 96-hr LC50 for phosphoric acid feli between a pH of 3.25 and 3.00 . The testing methodology involved exposing bluegill sunfish to decreasing increments of acid for $96-\mathrm{hr}$ intervals. After $96 \mathrm{hr}$ of exposure to a specified $\mathrm{pH}$ level, the $\mathrm{pH}$ was lowered to the next level. The $\mathrm{pH}$ levels tested were $7.5,5.0$, $4.5,4.0,3.5,3.25$ and 3.00 . Thirteen percent mortality was observed at $24 \mathrm{hr}$ at a pH of 3.25 and did not change over the remaining $96 \mathrm{hr}$ duration of the test. After adjusting the $\mathrm{pH}$ to 3.00 , mortality increased to $100 \%$ in the first $24 \mathrm{hr}$ of exposure.

The physiological and toxicological implications of acid-induced stress in fish was recently review by From (1980). Severe acid stress causes an accumulation of mucus on the gills that interferes with norma? gas exchange resulting in hypoxia and, ultimately, death. Sub-lethal acid stress results in a decreaşe in blood $\mathrm{pH}$ and disruption of homeostatic mechanisms. EffTuxes of $\mathrm{H}^{+}$and $\mathrm{CO}_{2}$ are reduced and $\mathrm{Na}$ may be lost across gill membranes. Higher, less debilitating $\mathrm{pH}$ levels $(5.0$ to 6.5$)$ may have subtle adverse affects on reproduction, i.e., depressed oocyte production, calcium regulation.

In the Experimental Lakes Area of Canada, long-term studies involving the artificial acidification of Lake 223 have shown a trend toward a reduction in the recruitment of lake trout (Salvelinus namaycush) and white sucker (Catostomas conmersoni) at pH levels between 5.0 and 5.4 (Mills 1984). Recruitment failure was noted in fathead minnow at pH levels of 5.8 two years before failure of the lake trout and white sucker populations. 


\section{Invertebrates}

Declines in the diversity of Chydorid cladocerans in New England Lakes has been attributed to increased acjdification caused by atmospheric deposition (Brakke, Davis and Kenlan 1984). Sedimentary remains of the exoskeletons of these macroinvertebrates were recovered from sediment cores and examined as a function of age to evaluate changes in the community structure. The data indicated that many species of chydorids tolerated $\mathrm{pH}$ values as low as 4.4. Species diversity increased in higher elevation lakes, presumably because of the lower buffering capacity of these oligotrophic lakes.

\section{Aquatic Insects}

Aquatic insects are relatively tolerant to acidification. Bell and Nebeker (1969) investigated the acute toxicity of acid on 10 species of larval aquatic insects representing four distinct orders: dragonfly (Odonata), stonefly (Plecoptera), caddisfly (Iricoptera) and mayfly (Ephemeroptera). The most insensitive species tested were two species of caddisflies (Brachycentrus americanus and Hydropsyche betten 1 ), which had 96-hr median tolerance Timits (TLm) for $\mathrm{pH}$ vaiues of 1.5 and 3.15. The most sensitive species tested were the stonefly Pteronarcys dorsata and the mayfly Ephemereila subvaria, which had mean 96-hr TLm for pH values of 4.25 and 4.65 , respectively. Long-term chronic exposures of the same species for 30 days increased the TLm of the pH. Values that caused $50 \%$ mortality after 30 -day exposure to acid were 0.23 to $1.17 \mathrm{pH}$ unjts greater than the $\mathrm{pH}$ values associated witb 96-hr TLm values (Bell 1971). The relative sensitivity of the species tested in the two studies was similar. The mayfly (E. Subvaria) was the most sensitive species tested; it had a 30-day TLm of 5.38. AduTt emergence was a more sensitive indicator of acid-induced stress than the 30-day TLm. The stonefly Isogenus frontalis had a $50 \%$ success rate of emergence at a pH of 6.6. The next two most sensitive species were $\underline{P}$. dorsata and $\underline{E}$. subvaria, the species that were most sensitive to acute $\mathrm{pH}_{\text {Tevels. }}$

\subsection{SGF NO. 2 FOG OIL}

The relative hazards of bulk, vaporized and photolyzed batches of bulk and vaporized fog oil are discussed with respect to the effects these processes had on the aqueous chemistry and aquatic toxicity of the fog oi?. Our results are compared to related data on other organic liquids.

\subsubsection{Fog 0 i Tapor Generation}

At the start of the project, both settling and bubbling of fog oil vapor were considered as methods for dosing water. The option of bubbling fog oil vapor through water was not investigated because the initial trial burns with RP-BR suggested the method was inefficient and did not represent natural processes. Scrubbing the vapor was perhaps the most efficient 
method of collecting fog oil vapor, but the resulting emulsion did not represent a medium that one would realistically expect to find in aquatic systems. Collecting fog oil vapor on glass wool filters was time consuming and inefficient. The methad of settling of fog oil vapor was selected because it most closely simulated field conditions by allowing sufficient time for the aerosol to age.

The initial generation of fog oil vapor was conducted with a $100 \% \mathrm{~N}_{2}$ atmosphere. In remaining vaporizations, the $\mathrm{N}_{2}$ was augmented with cornpressed air to more closely approximate the conditions under which fog oil vapor is generated in the field with the M3A3 generator. In the field, fog $0 i 1$ is vaporized on the exhaust manifold of the generator and is then transported from the generator by entrainment in the exhaust of the gasoline engine. Oxidation of fog oil constituents would not occur in a pure $\mathrm{N}_{2}$ environnent. Oxidized fog oil constituents would be expected to be more soluble in aqueous solution and, consequently, potentially more toxic to aquatic organisms. Although vapor generation in the presence of $6 \%$ air approximates the stoichiometric amount of $\mathrm{O}_{2}$ in a finely tuned gasoline engine, these conditions fall short of duplicating the conditions present in the M3A3 generator because constituents normally found in gasoline motor exhaust were absent in the generation system used on the project. Although the presence of free radicals was not determined in the first vaporization experiment (FO-1), the vaporized fog oil generated in that test was not as dark as the Batch 3 fog oil vaporized with $6 \%$ air (F0-4) in Phase II tests. The method used in the project provided the most representative generation of fog oil vapor for aquatic toxicity testing short of setting up a MBA3 generator in the $1 a b$.

\subsubsection{Fog 0il Chemistry}

Analysis of the three batches of fog oil revealed few differences among them. The presence of the unresolved envelope in gas chromatograms was consistent with analyses performed by Katz et al. (1980). The relative coloration of the oil was indicative of its age and extent of oxidation. Batch 1 was the oldest and, like Batch 2, arrived in a previously opened barrel. Batch 1 was distinctly darker than Batch 2. Batch 3 arrived in a virgin state and was transparent, suggesting that little oxidation had taken place. Analysis of the chromatograms of the three fog oils yielded no explanation of the differences in coloration.

The generation of $011 /$ water mixtures (OWMs) demonstrated that the fog oil contained mostly water-insoluble components. The low aqueous solubility of the fog oil directly affected our ability to generate toxic stock solutions with high concentrations of fog oil. As a result, only low molecular weight, water soluble compounds were found in solution. Stock solutions generated during Phase II of the project contained fog oil in excess of fog oil's solubility, as indicated by the continued separation of organic and aqueous fractions in the exposure aquaria. Because of the selective solubility of various components of the fog $0 i 1$, the potentia? 
toxic properties of the OWMs are different than what would be predicted from the overall composition of the bulk fog oil.

Vaporization of fog oit generally resulted in a loss of the more volatile, low molecular weight components of the fog oil. This loss was expected because the fog oil was vaporized at $600^{\circ} \mathrm{C}$. Chromatograms of the vaporized fog $0 i l$ and chromatograms of the bulk fog oil were similar: both had a multitude of peaks and an unresolved envelope. Very small changes in the fog oil as a result of vaporization could cause the observed changes in coloration of the condensed $0 i l$; those changes, however, would be obscured in the chromatograms. Few differences between the chromatograms of bulk and vaporized OWMs were noted, indicating again that the changes brought on by vaporization were subtle. Analyses performed during the photolysis experiments indicated that vaporization increased the number of free radicals.

From these investigations, it is apparent that photolysis of fog oils can increase the toxicity of aqueous extracts of the oils through two mechanisms. Production of polar materials that act as emulsifiers can create water-soluble fractions that have much higher concentrations of oil. The higher concentrations occur because surface tension is reduced and fewer suspensions of 011 droplets are produced. In this case, the toxic agent consists of fractions of the oil itself. On the other hand, photolysis can result in the production of chemicals (such as aromatic ketones) that have toxic properties apart from those of the original fog 011 .

Two types of adverse effects could result from the release of fog oil into aquatic systems: physical effects caused by contact with the $0 i 1$, and toxicity caused by the chemical constituents of the oil. Toxicity could result from exposure to soluble components of the oit or to hydrophobic oil droplets. The low solubility of fog oil constituents in aqueous solution limits the toxicity of the material to aquatic organisms. The solubility of the oil is determined by the selective extraction of the low molecular weight compounds found in both the bulk and vaporized fog oils. Based on total oil in water, the "solubility" of the 011 was estimated at $~ 30$ to $300 \mu \mathrm{g} / \mathrm{L}$. All stock solutions used during Phase II of the project exceeded this observed level of solubility. It is therefore difficult to interpret the data because the total oil values overestimate the chemical constituents that the aquatic organisms are exposed to over the duration of exposure. The problem is minor, however, because toxicity associated with these oversaturated exposure solutions was observed only when stock soiutions exceeded $10 \mathrm{mg} / \mathrm{L}$ for the invertebrate species. Thus, the adverse effects are probably due to physical interactions with the fog $0 i$.

\subsubsection{Aquatic Toxicity}

The tests with fog $0 i 1$ and $D$. magna provide an estimate of the concentrations of fog oil that could affect a natural population of filter feeding invertebrates. Nominal exposure concentrations as low as $30 \mu \mathrm{g} / \mathrm{L}$ 
caused floaters in the Phase II tests with D. magna. In order for these observations of floaters to have any ecological stgnificance, a mechanisms for mixing the fog oil in the water column must be present. Mixing energies derived from wind action on lakes and from the natural flow and turbulence of streams are sufficient to create oil-water dispersions similar to those created by the 0wMs generated in the laboratory. Thus, effects similar to those demonstrated in the laboratory are possible.

Except for toxicfty tests with algae, no discernible differences were evident among the three batches of fog oil. All three batches of fog oil showed some degree of growth inhibition after $96 \mathrm{hr}$ of exposure to the stock solutions ( $\geq 2.3 \mathrm{mg} / \mathrm{L}$ total $0 i 1)$; however, the inhibition was significant in only two of the three tests. The lack of significance in the Batch 3 test may be the result of weaknesses in the experimental design, specifically the use of three replicate flasks per treatment. Because the exposure flasks were routinely shaken every day, it is assumed that the separation of $0 i 1$ from the water column was less than that in other static exposure systems. In tests with algae, it is not possible to separate physical and toxicological effects of fog oil.

Based on the collective results of all the fog oil tests, we corclude that there were no differences in the toxicological properties of the three batches of fog oil. Vaporization of the fog oil in the presence of $\mathrm{O}_{2}$ caused subtle changes in the chemistry of the fog $0 i 1$, but these changes did not affect the toxic properties of the fog oil. The slight variations and trends noted in the tests with vaporized fog oil were well within the bounds of experimental error for the number of tests performed.

The potential toxicity of fog oil may be "put in perspective" by comparing the toxicity data of other complex organic liquids to $D$. magna (Dauble et al. 1983) with the results of our tests (Table 54). This comparison is appropriate because the tests with complex organic liquids were performed at PNL using the same method of preparing OWM preparation. On the basis of both solubility and toxicity, we conclude that the hazard to aquatic life posed by SGF No. 2 fog oil is comparable to or less than Prudhoe Bay crude oil or No. 2 Diesel fuel oil.

The 48-hr LC50 values in Table 62 are based on total carbon measurements of the exposure solutions. For the purposes of this comparison, concentrations of fog 0 il detemined by IR analysis were assumed to be equivalent to total carbon measurements used in the tests reported by Dauble et al. (1983). The materials tested include a number of materials derived from coal liquifaction, including process materials from Solvent Refined Coal (SRC), Integrated Two-Stage Liquifaction (ITSL), and Exxon Donor Solvent (EDS) technologies. These materials contain a high concentration of phenols, hence the relatively high concentration of soluble total carbon in the water soluble fraction (WSF). The WSF is comparable to the OWM. The stock solutions listed in Table 62 represent the soluble conponents of the stock solutions. A stock solution of fog oil would have a 
TABLE 62. COMPARATIVE TOXICITY TO DAPHNIDS OF INTEGRATED THO-STAGE

LIQUIFACTION (ITSL), EXXON DONOR SOLVENT (EDS), AND SEVERAL REFERENCE MATERIALS ${ }^{\mathrm{a}}$

\begin{tabular}{|c|c|c|c|}
\hline \multirow[b]{2}{*}{ Material } & \multirow[b]{2}{*}{$\begin{array}{l}\text { Concentration } \\
\text { of WSF (mg/L) }\end{array}$} & \multicolumn{2}{|c|}{$48-h r L C 50^{b}$} \\
\hline & & $\begin{array}{c}\text { Dilution } \\
(y)\end{array}$ & $\begin{array}{c}\mathrm{TC}^{\mathrm{C}} \\
(\mathrm{mg} / \mathrm{L}) \\
\end{array}$ \\
\hline $\begin{array}{l}\text { SRC-II distillate } \\
\text { blend }\end{array}$ & 1068 & 0.6 & 6.3 \\
\hline ITSL - LCF feed & 7 & 71.6 & 4.9 \\
\hline ITSL - liquid product & 9 & 85.0 & 7.4 \\
\hline $\begin{array}{l}\text { ITSL - distillate } \\
\quad 650^{\circ} \mathrm{F}\end{array}$ & 124 & 7.6 & 9.5 \\
\hline $\begin{array}{l}\text { EDS process solvent } \\
\text { once through }\end{array}$ & 103 & 4.7 & 5.1 \\
\hline $\begin{array}{l}\text { EDS process solvent } \\
\text { bottoms recycle }\end{array}$ & 161 & 3.8 & 6.2 \\
\hline Shale oil & 65 & 10.4 & 16.0 \\
\hline No. 2 diesel fuel & 9 & $\begin{array}{l}\text { None at } \\
100 \% \text { WSF }\end{array}$ & -- \\
\hline $\begin{array}{l}\text { No. } 6 \text { bunker feed } \\
\text { stock }\end{array}$ & 5 & $\sim 47.0$ & $\sim 2.4$ \\
\hline $\begin{array}{l}\text { Prudhoe Bay crude } \\
\text { oij }\end{array}$ & 3 & $\begin{array}{l}\text { None at } \\
100 \% \text { WSF }\end{array}$ & - \\
\hline \multicolumn{4}{|c|}{$\begin{array}{l}\text { adapted from Dauble et al. (1983). } \\
\text { belative solubility is indicated by total carbon (TC) in water soluble } \\
\text { fractions (WSFs) generated under similar conditions. } \\
\mathrm{C}_{\text {LC50 and WSF values are given as the mean of reported values. }}\end{array}$} \\
\hline \multicolumn{4}{|c|}{$\begin{array}{l}\text { comparative concentration of } 0.2 \text { to } 0.3 \mathrm{mg} / \mathrm{L} \text { as total oil. This level of } \\
\text { fog oil is high enough to cause physical impairment to filter feeding } \\
\text { organisms but is an order of magnitude lower than the concentrations } \\
\text { detrimental to algae and two orders of magnitude lower than the } \\
\text { concentrations having a detrimental effect on non-filter feeding } \\
\text { invertebrates tested in this project. }\end{array}$} \\
\hline
\end{tabular}


aqueous solubility. The absolute concentration of any one of the numerous oxidized constituents in the exposure solutions was very low and would not account for the observed toxicity unless the constituent was highiy toxic. We conclude that the observed toxicity was in response to the collective effects of the soluble constituents. No information on the aquatic toxicity of the compounds identified in the 7-day photolyzed fog $0 i 1$ are readily available. No information was available for ketones. The concentrations of photolyzed fog oil capable of eliciting acutely toxic responses in aquatic organisms are still relatively high compared to the toxicity of liquids derived from coal.

\subsection{FIELD EXTRAPOLATIONS}

This section discusses factors that may have the greatest impact on estimating the potential hazards these materials present to aquatic organisms. Generally, these factors include the amount of smoke generated, the duration of generation, and the volume and surface area of the receiving waters. For phosphorus-based obscurants, the buffering capacity of the receiving water is a major factor controlling toxicity.

\subsubsection{Phosphorus-Based Obscurants}

A general relationship between total $\mathrm{P}$, buffering capacity and $\mathrm{pH}$ can be developed from the different types of waters used in this project, (Table 63 . The relationship was developed by selecting the total $P$ values that resulted in a $\mathrm{pH}$ value of 6.0 in the various types of water. The data points were taken directly from exposure solutions with a $\mathrm{pH}$ of 6.0 or were visually estimated from curves showing the relationship between tota $1 P$ and $\mathrm{pH}$ in each dilution water. It should also be noted that this endpoint falls within the lower buffering range of bicarbonate ions. Major decreases in $\mathrm{pH}$ will not occur until the buffering capacity of the receiving water has been exceeded. The selection of $\mathrm{pH} 6.0$ was arbitrary and is used in this analysis simply as a point of reference. Acute toxicity, as indicated by 48- and 96-hr LC50 values, occurs at lower pH levels.

The relationship between the deployment of phosphorus-based obscurants, deposition into a body of water, and the resulting toxicity to aquatic organisms is complex. The key variables are the concentration of smoke generated, the deposition velocity, the duration of smoke generation, the size of the body of water that is exposed (surface area, volume and flow rate for streems), and the buffering capacity of the receiving water. The development of a complex model of these parameters is beyond the scope of this project; however, a general relationship based on the following simplified assumptions is possible:

1) The column of smoke generated is $20 \mathrm{~m}$ high and has a uniform smoke concentration of $300 \mathrm{mg} / \mathrm{m}^{3}$. 
TABLE 63. RELATIONSHIP BETWEEN BUFFERING CAPACITY AND TOTAL PHOSPHOROUS AT PH 6.0

\begin{tabular}{|c|c|c|c|c|}
\hline Media & Obscurant & $\begin{array}{l}\text { Buffering Capacity } \\
\left(\mathrm{CaCO}_{3} \mathrm{mg} / \mathrm{L}\right)\end{array}$ & $\begin{array}{l}\text { Total }-P \\
(\mathrm{mg} / \mathrm{L})\end{array}$ & $\mathrm{pH}$ \\
\hline $\begin{array}{l}\text { Algae Media } \\
\text { Algae Media } \\
\text { Algae Media }\end{array}$ & $\begin{array}{l}W P-F \\
W P-F \\
\text { RP-BR }\end{array}$ & $\begin{array}{l}16 \\
16 \\
16\end{array}$ & $\begin{array}{l}2.2 \\
7.5 \\
2.85\end{array}$ & $\begin{array}{l}6.0 \\
6.06 \\
6.08\end{array}$ \\
\hline $\begin{array}{l}\text { Reconstituted Soft } \\
\text { Reconstituted Soft }\end{array}$ & $\begin{array}{l}\text { WP-F } \\
\text { RP-BR }\end{array}$ & $\begin{array}{l}32.5 \\
38\end{array}$ & $\begin{array}{l}12^{\mathrm{a}} \\
14^{\mathrm{a}}\end{array}$ & $\begin{array}{l}6.0 \\
6.0\end{array}$ \\
\hline $\begin{array}{l}\text { River } \\
\text { River }\end{array}$ & $\begin{array}{l}W P-F \\
R P-B R\end{array}$ & $\begin{array}{l}65 \\
65\end{array}$ & $\begin{array}{l}20.7 \\
23.8\end{array}$ & $\begin{array}{l}6.15 \\
6.00\end{array}$ \\
\hline $\begin{array}{l}\text { We } 11 \\
\text { Well } \\
\text { Wel1 }\end{array}$ & $\begin{array}{l}W P-F \\
W P-F \\
R P-B R\end{array}$ & $\begin{array}{l}115 \\
115 \\
117\end{array}$ & $\begin{array}{l}62^{a} \\
57^{a} \\
62^{a}\end{array}$ & $\begin{array}{l}6.0 \\
6.0 \\
6.0\end{array}$ \\
\hline $\begin{array}{l}\text { Reconstituted Hard } \\
\text { Reconstituted Hard } \\
\text { Reconstituted Hard } \\
\text { Reconstituted Hard }\end{array}$ & $\begin{array}{l}W P-F \\
W P-F \\
R P-B R \\
R P-B R\end{array}$ & $\begin{array}{l}117 \\
129 \\
124 \\
112\end{array}$ & $\begin{array}{l}65.2 \\
35 a^{4} \\
62^{a} \\
58\end{array}$ & $\begin{array}{l}6.00 \\
5.99 \\
6.0 \\
6.0\end{array}$ \\
\hline $\begin{array}{l}\text { Reconstituted Very Hard } \\
\text { Reconstituted Very Hard }\end{array}$ & $\begin{array}{l}W P-F \\
W P-F\end{array}$ & $\begin{array}{l}227 \\
220\end{array}$ & $111^{\mathrm{a}}$ & $\begin{array}{l}6.0 \\
6.0\end{array}$ \\
\hline
\end{tabular}

Estimated total $\mathrm{P}$ at $\mathrm{pH} 6.0$.

2) The smoke screen is instantaneously generated and instantaneousiy settles into a body of water with a setting efficiency of $100 \%$.

3) The relationship between total $\mathrm{P}, \mathrm{pH}$, and buffering capacity of the receiving water is defined by the following regression equation based on the amount of total $\mathrm{P}$ required to lower the $\mathrm{ph}$ of a receiving water of $X$ buffering capacity to 6.0 :

$$
y(\mathrm{mg} / \mathrm{L} \text { total } \mathrm{P})=0.51 \times\left(\mathrm{mg} / \mathrm{L} \mathrm{CaCO}_{3} \text { alkalinity }\right)-4.44
$$

The coefficient of correlation for this relationship is 0.94 . 
For example, assume that a $3000-\mathrm{m}^{2}$ pond with a mean depth of 1.5 m has been exposed to a phosphorus smoke screen. The pond has an alkalinity of $100 \mathrm{mg} / \mathrm{L} \mathrm{CaCO}_{3}$ and contains $4.5 \times 10^{6} \mathrm{~L}$. The amount of smoke above the pond amounts to $18 \mathrm{~kg}$ of smoke distributed in $60,000 \mathrm{~m}^{3}$ of air. Assuming that all the smoke settles into the pond, the resulting total $\mathrm{P}$ concentration would be $4 \mathrm{mg} / \mathrm{L}$. According to the regression equation, the estimated amount of phosphorus necessary to lower the pH of the pond to a pH of 6.0 is $51 \mathrm{mg} / \mathrm{L}$. Consequently, more than 10 times the amount of smoke found in the smoke screen would be necessary to lower the pond to a $\mathrm{pH}$ of 6.0 . The actual amount of smoke deposited in the water, however, would depend on wind speed and its effect on deposition velocity. Other variables would also influence the change in $\mathrm{pH}$ of a pond exposed to phosphorus smoke. For example, the conditions under which the smoke was generated could radically affect the speciation of phosphorus combustion products in the smoke. Relative humidity, photolysis, and aging of the smoke before it settles on the water could affect the potential for acidification. Prolonged contact with soil or suspended dust may accelerate the decomposition of the more complex polyphosphates to orthophosphate. The dust or soil particles may adsorb and buffer smoke constituents, thus minimizing the potential for acidification if they were to be washed into a body of water. For these reasons, a scenario of aquatic hazards based on surface runoff into a body of water was not addressed further.

\subsubsection{Fog 0 il}

The primary detrimental effect posed to aquatic organisms by the release of fog oil is physical contact with the $0 i 1$. As indicated by the low concentrations of oil that cause the "floater" phenomenon with first instar $\underline{D}$. magna, small amounts of fog oil can cause potential problems. The potential for these types of effects to occur in aquatic habitats depends on a number of variables, such as the characteristics of the receiving water, the amount of fog oil released, and the mode of release (spillage or vapor settling). An exercise analogous to the one presented for phosphorus-based obscurants can be conducted using the first two assumptions; however, because fog oil will float on the surface, initial effects would be restricted to the upper layers of a lake or stream unti] sufficient time had elapsed for fog 011 to disperse into other zones of the lake or stream. A uniform distribution of fog oil in the water column cannot be assumed, nor can a mean concentration of dissolved fog oil in water.

From a toxicological point of view, neither the bulk nor the vaporized fog oil appears to be acutely toxic. The potential for acute detrimenta? environmental effects would be underestimated without consideration of the effects photolysis has on the solubility and potential toxicity of fog 0 it.

More information is needed to assess adequately the potential environmental problems associated with photolytic decomposition of fog oils. The products of fog oil photodecomposition have only been investigated in a 
preliminary fashion, consistent with the scope of the toxicity testing program. $\Lambda$ Tthough aromatic ketones of intermediate molecular weight have been identified, other types of products such as ethers and carboxylic acids are probably formed. In addition, compounds with lower and higher molecular weights were not identified or analyzed in these studies, and are undoubtedly formed by photolysis.

We have no data that relate the amount of solar radiation to the amounts of oxygenated products produced by photolys is. Quantitative methods for determining product formation with time should be developed, taking into account the quantity of fog oil which would be exposed to sunlight during a typical smoke screen exercise. Both mathematical studies and wind tunnei experiments should be conducted to determine the efficiency of the photolysis reactions in an aerosol situation. In addition, models need to be developed that relate quantity of photolyzed $0 i 1$ to environmental

perturbations. Further, the potential impact of fog oil photolys is on terrestrial systems, both plant and animal, should be studied.

From the perspective of "acute" effects, the potential hazards to aquatic organisms are relatively low. In contrast, we know very little about the long-term effects of chronic releases of fog oit in freshwater aquatic systems. Many processes such as photolysis, dissolution, sedimentation, biological transformation, concentration of lipid-soluble toxins, and food chain transport ultimately influence the disposition of oils in the environment (Liss-Suter 1978). Most of the research in this area deals with oil spills in the marine environment. Available information on the long-term fate of fog oil, with its distinctive chemical composition, is limited. More research addressing the environmental fate and effects of fog $0 i 1$ in freshwater systems is needed to define and model these processes. 


\subsection{CONCLUSIONS AND RESEARCH RECOMMENDATIONS}

study.

Several major conclusions and recommendations can be drawn from this

1. The primary mode of toxicity of the phosphorus-based obscurants results from acidification of the receiving water. Susceptibility of aquatic organisms to Phosphorus-based obscurants was determined by the inherent buffering capacity of the receiving waters.

2. None of the constituents of $R P-B R$ or WP-F smoke were toxic except at high concentrations of total $P$. The accumulation of tri-meta-phosphate over time suggests that chronic studies with the compound are needed to define the potential hazard it presents to aquatic organisms.

3. SGF No. 2 Fog 011 does not exert any apparent chemical toxicity to aquatic organisms. Physical impairment of aquatic organisms is the createst adverse effect. The potential effects that photolys is has on the production of water-soluble constituents and thefr resulting toxicity needs additional research, particulariy in the area of actua? photolysis of the aerosol and subsequent settling and dissolution in water. 


\subsection{REFERENCES}

American Society for Testing and Materials (ASTM). 1980. Standard Practice for Conducting. Acute Toxicity Tests with Fishes, Macroinvertebrates and Amphibians. ASTM Standard E729, American Society for Testing and Materials, Philadelphia, Pennsylvania.

Ballou, J. E. 1981. Chemical Characterization and Toxicological Evaluation of Airborne Mixtures, Final Report. Prepared for U.S. Army Biomedical Research and Development Command by Battelle, Pacific Northwest Laboratories, Richland, Washington.

Bean, R. M., C. D. Becker, J. R. Skalski, W. E. Fallon, A. J. Scott, K. Shiosaki and B. Wilson. 1981. "Aqueous Suspensions of SolventRefined Coal Liquids: Effect of Preparation Procedure on Resulting Chemical Composition and Toxicity." In Coal Conversion and the Environment, p. 198. Technical Information Center/U.S. Department of Energy, Washington, D.C.

Bel1, H. L. 1971. "Effect of Low pH on the Survival and Emergence of Aquatic Insects." Wat. Res. 5:313-319.

Bell, H. L., and A. V. Nebeker. 1969. "Preliminary Studies on the Tolerance of Aquatic Insects to Low pH." J. Kansas Entomol. Soc. $42: 230-236$.

Berkowitz, J. B., G. S. Young, R. C. Anderson, A. J. Colela, W. J. Lyman, A. L. Preston, W. D. Steber, R. G. Thomas and R. G. Vranka. 1981. Occupational and Environmental Hazards Associated with the Formulation and Use of thite Phosphorus-Felt and Red Phosphorus-Butyl Rubber Screening Smokes. Final Report, AD Al16956, Arthur D. Littie, Inc., Cambridge, Massachusetts. DAMD17-79-C-9139.

Brakke, D. F., R. B. Davis and K. H. Kentan. 1984. "Acidification and Changes Over Time in the Chydorid Cladoceran Assemblage of New England Lakes." In Early Responses to Advancing Lake Acidification, ed. G. R. Hendrey, pp. 85-104. Butterworth Publishers, Boston, Massachusetts.

Brazel1, R. S., R. W. Holmberg and J. H. Moneyhun. 1984. "Application of High Performance Liquid Chromatography-Flow Injection Analysis for the Determination of Polyphosphoric Acids." J. Chromatog. 290:163-172.

Dauble, D. D., A. J. Scott, E. W. Lusty, B. L. Thomas and R. W. Hanf, Ir. 1983. Ecotoxicity of Materials from Integrated Two-Stage Liquefaction and Exxon Donor Solvent Process. PNL-4675, Pacific Northwest Laboratory, Richland, Washington. 
Ellgaard, E. G., and J. Y. Gilmore. 1984. "Effects of Different Acids on the Bluegill Sunfish, Lepomis machrochirus Rafinesque." J.Fish Biol. $25: 133-137$.

Environmental Protection Agency, 1976. Quality Criteria for Water. U.S. Environmental Protection Agency, Washington, 0.C.

Fromm, P. 0. 1980. "A Review of Some Physiological and Toxicological Responses of Freshwater Fish to Acid Stress." Env. Biol. Fish. 5:79-93.

Goulden, C. E., R. M. Comotto, J. A. Hendrickson, Jr., L. L. Hornig and K. L. Johnson. 1982. "Procedures and Recommendation for the Culture and Use of Daphnia in Bioassay Studies." In Aquatic Toxicology and Hazard Assessment: Fifth Conference, ASTM STP 766, pp. $139-160$, eds. J. G. pearson, R. B. Foster, and W. E. Bishop. American Society for Testing and Materials, Philadelphia, Pennsylvania.

Hamitton, M. A., R. C. Russo and R. V. Thurston. 1977. "Trimmed SpearmanKarber Method for Estimating Median Lethal Concentrations in Toxicity Tests." Environ. Sci. Technol. 11:714-719.

Heller, S. R., and G. W. A. Milne. 1978. EPA/NIH Mass Spectral Data Base. U.S. National Bureau of Standards, National Standard Reference Data Series, NSRDS-NBS 63, U.S. Government Printing Office, Washington, D.C.

Henlrey, G. R. 1984. Early Biotic Responses to Advancing Lake Acidification. Acid Precipitation Series, Vol. 6, (Preface). Butterworth Publishers, Boston, Massachusetts.

Katz, S., A. Snelson, R. Butler, R. Farlow, R. Welker and S. Mainer. 1980. Physical and Chemical Characterization of Military Smokes. Part I I Fog Ofls and 0iT Fogs. Final Report, AD A093205, MT Research Institute, Chicago, III inois. DAMD17-78-C-8085.

Katz, S., A. Snelson, R. Butter, W. Bock, N. Rajendron and S. Relwani. 1981. Physical and Chemical Characterization of Military Smokes. Part III. White Phosphorus-Felt Smokes. Final Report, AD (not available), IIT Research Institute, Chicago, I1 1 inois, DAMD17-78-C-8085.

Lai, M. G. 1979. Characterization of White Phosphorus in Water. 1. Determination of White Phosphorus in Environmental Waters at the Nanogram Level. NSCW TR 79-3, Nava? Surface Weapons Center, Silver Spring, Maryland.

Liss-Suter, D. 1978. Environmental Aspects of Diesel Fuels and Fog 0ils SGF No. 1 and SGF No.2 and Smoke Screens Generated From Them. Find Report, AD A056021, The Franklin Institute Research Laboratories, Philadelphia, Pennsylvania. DAMD17-77-C-7020. 
Lorenzen, C. J. 1966. "A Method for the Continuous Measurement of In Vivo Chlorophyll Concentration." Deep-sea Res. 13:223-227.

Marking, L. L., and V. K. Dawson. 1973. "Toxicity of Quinaldine Sulfate to Fish." Invest. Fish Control. No. 48, U.S. Fish and Wildlife Service, Hashington, D.C..

Mass Spectrometry Data Centre. 1974. Eight Peak Index of Mass Spectra. AWRE, Aldermaston, Reading, RG7 4PR, United Kingdom.

McKee, J. E., and H. A. Wolf. 1971. Water Quality Criteria. 2nd Edjtion, Publication 3-A, State Water Resources Control Board, State of California.

Miller, W. E., J. C. Greene, and T. Shiroyama. 1978. The Selenastrum capricornutum Printz Algal Assay Bottle Test. EPA-600/9-78-018, U. S. Environmental Protection Agency, Corvatîs, Oregon.

Mills, K. H. 1984. "Fish Population Responses to Experimental Acidification of a Small Ontario Lake." In Early Biotic Responses to Advancing Lake Acidification, ed. G. R. Hendrey, pp. 117-132. Butterworth Publishers, Boston, Massachusetts.

Nichols, H. W., and H. C. Bold. 1965. Trichosarcina polymorpha gen. et sp. nov.. J. Phycol. 1:34-35.

Silverstein, R. M., G. C. Bassler and T C. Morril1. 1974. Spectrometric Identification of Organic Compounds. 3rd Edition, Wiley \& Sons, Inc., New York.

Sullivan, J. H., H. D. Putnam, M. A. Keirn, B. C. Pruit, Jr., J. C. Nichols and J. T. McClave. 1979. A Summary and Evaluation of Aquatic Environmental Data in Relation to Establishing Water Quality Criteria for Munitions-Unique Compounds. Part 3: White Phosphorus. Final Report, AD (not avaflable), Water and Air Research, Inc., Gainesville, Florida. DAMD17-77-C-7027.

Van Voris, P., M. W. Ligotke, K. M. McFadden, R. M. Bean, D. A. Cataldo, T. R. Garland and J. E. Rogers. 1985. Evaluate and Characterize Mechanisms Controlling Transport, Fate and Effects of Army Smokes in PNL Aerosol Wind Tunnel. Progress Report No. 9, February 15, 1985, Project No. 84PP4819, Pacific Northwest Laboratory, Richland, Washington.

Van Voris, P., M. W. Ligotke, D. A. Cataldo, T. R. Garland, J. E. Rogers and K. M. McFadden. 1984. Evaluation and Characterize Mechanisms Controlling Transport, Fate and Effects of Army Smokes in Aerosol Wind Tunnel. Progress Report No. 3, August 9, 1984, Project No. 84PP4819, Pacific Northwest Laboratory, Richland, Washington. 
Van Wazer, J. R. 1958. Phosphorus and Its Compounds. Vol. 1, Chemistry. Interscience Publishers, Inc., New York.

Warner, J. S. 1976. "Determination of $\mathrm{Mliphatic}$ and Aromatic Hydrocarbons in Marine Organisms." Anal. Chem. 48:578.

Wetzel, R. G. 1975. Limnology. W. B. Saunders Co., Philadelphia, Pennsylvania.

Winer, B. J. 1971. Statistical Principles in Experimental Design. McGraw-Hill Company, New York.

Yamaguchi, H., T. Nakamura, Y. Hirai and S. Ohashi. 1979. "High Performance Liquid Chromatographic Separation of Linear and Cyclic Condensed Phosphates." J.Chromatog. 172:131-140. 


\section{APPENDIX A}

TOXICITY DATA FOR ALCAE TESTS

TABLE A.1. MEAN! CELL COUNTS ( \pm 1.0 SD) FOR SELENASTRIIM CAPRICGRMUTUM EXPOSED TO BATCH 1 FOG OIL

\begin{tabular}{|c|c|c|c|c|c|c|}
\hline \multirow{2}{*}{$\begin{array}{l}\text { Treatment } \\
\text { (8 stock) }\end{array}$} & \multirow{2}{*}{$\begin{array}{c}\text { Total 0i1 } \\
(\mathrm{mg} / \mathrm{L})\end{array}$} & \multicolumn{5}{|c|}{ Mean Cells Count $\left(\times 10^{3} / \mathrm{mL}^{2}\right)$} \\
\hline & & $\mathrm{Ohr}$ & $24 \mathrm{hr}$ & $48 \mathrm{hr}$ & $72 \mathrm{hr}$ & $96 \mathrm{hr}$ \\
\hline 100 & 3.23 & $\begin{array}{l}8.96 \\
1.00\end{array}$ & $\begin{array}{r}22.51 \\
3.88\end{array}$ & $\begin{array}{r}23.50 \\
2.11\end{array}$ & $\begin{array}{l}77.01 \\
19.86\end{array}$ & $\begin{array}{l}348.45 \\
118.98\end{array}$ \\
\hline 60 & 2.15 & $\begin{array}{l}16.76 \\
11.35\end{array}$ & $\begin{array}{r}25.09 \\
2.56\end{array}$ & $\begin{array}{r}19.10 \\
7.39\end{array}$ & $\begin{array}{l}80.74 \\
12.56\end{array}$ & $\begin{array}{r}633.25 \\
95.55\end{array}$ \\
\hline 40 & 1.66 & $\begin{array}{l}8.61 \\
1.73\end{array}$ & $\begin{array}{r}24.32 \\
3.33\end{array}$ & $\begin{array}{r}29.14 \\
3.23\end{array}$ & $\begin{array}{l}99.79 \\
50.65\end{array}$ & $\begin{array}{r}1060.45 \\
115.56\end{array}$ \\
\hline 20 & 0.95 & $\begin{array}{l}7.81 \\
0.67\end{array}$ & $\begin{array}{r}27.42 \\
2.95\end{array}$ & $\begin{array}{r}30.04 \\
9.47\end{array}$ & $\begin{array}{l}91.05 \\
18.80\end{array}$ & $\begin{array}{r}1048.27 \\
212.58\end{array}$ \\
\hline 10 & 0.67 & $\begin{array}{r}10.65 \\
2.83\end{array}$ & $\begin{array}{r}24.45 \\
4.96\end{array}$ & $\begin{array}{r}46.93 \\
7.31\end{array}$ & $\begin{array}{r}148.36 \\
9.06\end{array}$ & $\begin{array}{r}1282.03 \\
440.57\end{array}$ \\
\hline 5 & 0.76 & $\begin{array}{l}8.33 \\
3.23\end{array}$ & $\begin{array}{r}21.51 \\
2.42\end{array}$ & $\begin{array}{r}27.72 \\
2.33\end{array}$ & $\begin{array}{r}183.29 \\
85.21\end{array}$ & $\begin{array}{r}1103.31 \\
99.75\end{array}$ \\
\hline Control & 0.14 & $\begin{array}{l}9.69 \\
4.72\end{array}$ & $\begin{array}{r}29.80 \\
1.18\end{array}$ & $\begin{array}{r}75.21 \\
4.97\end{array}$ & $\begin{array}{r}214.49 \\
82.97\end{array}$ & $\begin{array}{r}1004.21 \\
838.37\end{array}$ \\
\hline
\end{tabular}


TABLE A.2. MEAN CELL COUNTS $( \pm 1.0$ SD) FOR SELENASTRUM CAPRICORNUTUM EXPOSED TO BATCH 2 FOG OIL

\begin{tabular}{|c|c|c|c|c|c|c|}
\hline \multirow{2}{*}{$\begin{array}{l}\text { Treatment } \\
\text { (stock) }\end{array}$} & \multirow{2}{*}{$\begin{array}{c}\text { Total } 0 i 1 \\
(\mathrm{mg} / \mathrm{L})\end{array}$} & \multicolumn{5}{|c|}{ Mean CelT Count (x $\left.10^{3} / \mathrm{mL}\right)$} \\
\hline & & $0 \mathrm{hr}$ & $24 \mathrm{hr}$ & $48 \mathrm{hr}$ & $72 \mathrm{hr}$ & $96 \mathrm{hr}$ \\
\hline 100 & 2.39 & $\begin{array}{r}199.82 \\
16.51\end{array}$ & $\begin{array}{l}411.71 \\
221.38\end{array}$ & $\begin{array}{r}692.30 \\
89.78\end{array}$ & $\begin{array}{r}7284.38 \\
682.91\end{array}$ & $\begin{array}{r}2242.66 \\
127.89\end{array}$ \\
\hline 80 & 1.44 & $\begin{array}{r}212.28 \\
22.25\end{array}$ & $\begin{array}{r}249.44 \\
31.16\end{array}$ & $\begin{array}{l}986.76 \\
113.39\end{array}$ & $\begin{array}{r}1569.93 \\
3.21\end{array}$ & $\begin{array}{r}2587.53 \\
168.54\end{array}$ \\
\hline 40 & 1.17 & $\begin{array}{r}210.63 \\
15.15\end{array}$ & $\begin{array}{r}295.13 \\
28.61\end{array}$ & $\begin{array}{r}1099.98 \\
87.73\end{array}$ & $\begin{array}{r}2047.65 \\
229.83\end{array}$ & $\begin{array}{r}3672.06 \\
203.84\end{array}$ \\
\hline 20 & 0.65 & $\begin{array}{r}205.72 \\
19.72\end{array}$ & $\begin{array}{r}302.80 \\
7.88\end{array}$ & $\begin{array}{r}1096.00 \\
81.92\end{array}$ & $\begin{array}{r}2253.73 \\
150.16\end{array}$ & $\begin{array}{l}2757.70 \\
1278.41\end{array}$ \\
\hline 10 & 0.45 & $\begin{array}{r}200.94 \\
19.38\end{array}$ & $\begin{array}{r}365.36 \\
20.84\end{array}$ & $\begin{array}{r}1246.11 \\
59.12\end{array}$ & $\begin{array}{r}2507.90 \\
71.81\end{array}$ & $\begin{array}{r}3859.32 \\
295.79\end{array}$ \\
\hline 5 & 0.29 & $\begin{array}{r}214.16 \\
28.14\end{array}$ & $\begin{array}{r}437.57 \\
28.95\end{array}$ & $\begin{array}{l}741.56 \\
237.86\end{array}$ & $\begin{array}{r}1681.73 \\
551.85\end{array}$ & $\begin{array}{r}2772.08 \\
761.98\end{array}$ \\
\hline 0 & 0.20 & $\begin{array}{r}203.86 \\
16.15\end{array}$ & $\begin{array}{r}372.11 \\
28.71\end{array}$ & $\begin{array}{r}1719.68 \\
54.83\end{array}$ & $\begin{array}{r}2544.48 \\
210.47\end{array}$ & $\begin{array}{r}3207.42 \\
163.84\end{array}$ \\
\hline
\end{tabular}

TABLE A.3. MEAN CELL COUNTS $( \pm 1.0$ SD) FOR SELENASTPUM CAPRICORNUTIMM EXPOSED TO BATCH 3 FOG OIL

\begin{tabular}{|c|c|c|c|c|c|c|}
\hline \multirow{2}{*}{$\begin{array}{l}\text { Treatment } \\
\text { (s stock) }\end{array}$} & \multirow{2}{*}{$\begin{array}{l}\text { Total } 0 \text { il } \\
(\mathrm{mg} / \mathrm{L})\end{array}$} & \multicolumn{5}{|c|}{ Means Cel1 Counts $\left(x 10^{3} / \mathrm{mL}\right)$} \\
\hline & & $0 \mathrm{hr}$ & $24 \mathrm{hr}$ & $48 \mathrm{hr}$ & $72 \mathrm{hr}$ & $96 \mathrm{hr}$ \\
\hline $100:$ & 3.47 & $\begin{array}{l}18.28 \\
10.97\end{array}$ & $\begin{array}{l}19.51 \\
14.97\end{array}$ & $\begin{array}{l}64.41 \\
41.22\end{array}$ & $\begin{array}{l}385.17 \\
277.46\end{array}$ & $\begin{array}{l}604.09 \\
584.79\end{array}$ \\
\hline 60 & 2.75 & $\begin{array}{r}13.77 \\
9.59\end{array}$ & $\begin{array}{l}27.01 \\
15.04\end{array}$ & $\begin{array}{l}55.29 \\
43.53\end{array}$ & $\begin{array}{l}364.91 \\
258.81\end{array}$ & $\begin{array}{l}822.25 \\
722.98\end{array}$ \\
\hline 40 & 2.56 & $\begin{array}{l}13.09 \\
10.33\end{array}$ & $\begin{array}{l}16.99 \\
15.17\end{array}$ & $\begin{array}{l}60.61 \\
42.71\end{array}$ & $\begin{array}{l}356.12 \\
262.95\end{array}$ & $\begin{array}{r}1268.01 \\
973.66\end{array}$ \\
\hline 20 & 1.07 & $\begin{array}{l}9.91 \\
7.08\end{array}$ & $\begin{array}{l}19.56 \\
14.46\end{array}$ & $\begin{array}{l}57.76 \\
44.80\end{array}$ & $\begin{array}{l}298.53 \\
318.58\end{array}$ & $\begin{array}{r}1064.74 \\
754.23\end{array}$ \\
\hline 10 & 0.61 & $\begin{array}{l}5.61 \\
6.34\end{array}$ & $\begin{array}{l}17.18 \\
12.60\end{array}$ & $\begin{array}{l}50.65 \\
40.17\end{array}$ & $\begin{array}{l}336.91 \\
248.17\end{array}$ & $\begin{array}{r}1100.70 \\
783.01\end{array}$ \\
\hline Contrel & 0.09 & $\begin{array}{l}6.80 \\
4.99\end{array}$ & $\begin{array}{l}20.68 \\
15.61\end{array}$ & $\begin{array}{l}65.61 \\
47.64\end{array}$ & $\begin{array}{l}397.33 \\
296.37\end{array}$ & $\begin{array}{r}1064.94 \\
808.30\end{array}$ \\
\hline
\end{tabular}


TABLE A.4. MEAN CELL COUNTS $( \pm 1.0$ SD) FOR SELEMMSTRUM CAPRICORNUTTHM EXPOSED TO VAPORIZED BATCH 3 FOG OIL

\begin{tabular}{|c|c|c|c|c|c|c|}
\hline \multirow{2}{*}{$\begin{array}{l}\text { Treatment } \\
(8 \text { stock }) \\
\end{array}$} & \multirow{2}{*}{$\begin{array}{c}\text { Total } 0 i 1 \\
(\mathrm{mg} / \mathrm{L}) \\
\end{array}$} & \multicolumn{5}{|c|}{ Mean Cell Count $\left(\times 10^{3} / \mathrm{mL}\right)$} \\
\hline & & $0 \mathrm{hr}$ & $24 \mathrm{hr}$ & $48 \mathrm{hr}$ & $72 \mathrm{hr}$ & $96 \mathrm{hr}$ \\
\hline 100 & 2.38 & $\begin{array}{r}21.42 \\
2.54\end{array}$ & $\begin{array}{r}40.27 \\
1.89\end{array}$ & $\begin{array}{r}88.87 \\
4.20\end{array}$ & $\begin{array}{l}238.66 \\
160.07\end{array}$ & $\begin{array}{l}828.56 \\
162.32\end{array}$ \\
\hline 60 & 1.48 & $\begin{array}{r}18.44 \\
1.56\end{array}$ & $\begin{array}{r}43.55 \\
6.69\end{array}$ & $\begin{array}{l}98.32 \\
16.79\end{array}$ & $\begin{array}{l}369.43 \\
136.00\end{array}$ & $\begin{array}{r}1021.40 \\
500.59\end{array}$ \\
\hline 40 & 1.10 & $\begin{array}{r}23.01 \\
2.39\end{array}$ & $\begin{array}{r}47.39 \\
3.54\end{array}$ & $\begin{array}{r}112.57 \\
10.99\end{array}$ & $\begin{array}{r}364.43 \\
91.01\end{array}$ & $\begin{array}{l}948.11 \\
359.07\end{array}$ \\
\hline 20 & 0.76 & $\begin{array}{r}21.17 \\
0.60\end{array}$ & $\begin{array}{r}45.68 \\
1.28\end{array}$ & $\begin{array}{r}111.97 \\
5.67\end{array}$ & $\begin{array}{l}368.57 \\
167.14\end{array}$ & $\begin{array}{l}971.52 \\
170.31\end{array}$ \\
\hline 10 & 0.68 & $\begin{array}{r}24.79 \\
3.06\end{array}$ & $\begin{array}{r}48.61 \\
6.11\end{array}$ & $\begin{array}{r}116.27 \\
33.45\end{array}$ & $\begin{array}{r}461.88 \\
35.75\end{array}$ & $\begin{array}{r}1349.79 \\
40.20\end{array}$ \\
\hline Control & 0.18 & $\begin{array}{r}26.34 \\
4.73\end{array}$ & $\begin{array}{r}45.53 \\
2.52\end{array}$ & $\begin{array}{r}131.42 \\
14.48\end{array}$ & $\begin{array}{r}429.53 \\
51.45\end{array}$ & $\begin{array}{l}837.57 \\
103.46\end{array}$ \\
\hline
\end{tabular}

TABLE A.5. MEAN CELL COUNTS ( \pm 1.0 SD) FOR SELENASTPUNM CAPRICORNUTUIY EXPOSED TO RP-BR SMOKE-DOSED WATER

\begin{tabular}{|c|c|c|c|c|c|c|}
\hline \multirow{2}{*}{$\begin{array}{l}\text { Treatment } \\
\text { (q stock) }\end{array}$} & \multirow{2}{*}{$\begin{array}{c}\text { Total } 0 \text { il } \\
(\mathrm{mg} / \mathrm{L})\end{array}$} & \multicolumn{5}{|c|}{ Mean Cell Count $\left(\times 10^{3} / \mathrm{mL}\right)$} \\
\hline & & $0 \mathrm{hr}$ & $24 \mathrm{hr}$ & $48 \mathrm{hr}$ & $72 \mathrm{hr}$ & $96 \mathrm{hr}$ \\
\hline 100 & 97.0 & $\begin{array}{r}13.41 \\
1.07\end{array}$ & $\begin{array}{r}13.09 \\
0.64\end{array}$ & $\begin{array}{r}12.71 \\
0.82\end{array}$ & $\begin{array}{l}6.78 \\
4.08\end{array}$ & $\begin{array}{l}28.31 \\
23.61\end{array}$ \\
\hline 10 & 9.3 & $\begin{array}{r}20.90 \\
2.94\end{array}$ & $\begin{array}{r}15.71 \\
0.93\end{array}$ & $\begin{array}{r}16.78 \\
1.05\end{array}$ & $\begin{array}{r}11.71 \\
4.74\end{array}$ & $\begin{array}{r}17.73 \\
1.96\end{array}$ \\
\hline 9 & 8.6 & $\begin{array}{l}23.34 \\
10.78\end{array}$ & $\begin{array}{r}17.23 \\
1.19\end{array}$ & $\begin{array}{r}15.12 \\
2.09\end{array}$ & $\begin{array}{r}10.75 \\
3.04\end{array}$ & $\begin{array}{l}23.01 \\
15.39\end{array}$ \\
\hline 7 & 6.1 & $\begin{array}{r}20.05 \\
3.86\end{array}$ & $\begin{array}{r}22.83 \\
4.31\end{array}$ & $\begin{array}{r}16.69 \\
3.17\end{array}$ & $\begin{array}{l}5.45 \\
1.19\end{array}$ & $\begin{array}{l}63.05 \\
69.85\end{array}$ \\
\hline 5 & 4.6 & $\begin{array}{r}16.16 \\
0.99\end{array}$ & $\begin{array}{r}44.10 \\
5.23\end{array}$ & $\begin{array}{r}166.03 \\
11.30\end{array}$ & $\begin{array}{r}100.35 \\
70.77\end{array}$ & $\begin{array}{r}3363.16 \\
797.44\end{array}$ \\
\hline$t$ & 1.0 & $\begin{array}{r}17.91 \\
0.83\end{array}$ & $\begin{array}{r}40.05 \\
8.73\end{array}$ & $\begin{array}{l}93.54 \\
44.30\end{array}$ & $\begin{array}{l}38.61 \\
26.15\end{array}$ & $\begin{array}{l}573.93 \\
801.16\end{array}$ \\
\hline Control & 0 & $\begin{array}{r}17.38 \\
3.38\end{array}$ & $\begin{array}{r}40.95 \\
7.47\end{array}$ & $\begin{array}{r}118.50 \\
23.28\end{array}$ & $\begin{array}{r}103.01 \\
79.48\end{array}$ & $\begin{array}{r}195.20 \\
122.83\end{array}$ \\
\hline $100^{a}$ & 75 & $\begin{array}{r}25.14 \\
7.90\end{array}$ & $\begin{array}{r}29.72 \\
2.83\end{array}$ & $\begin{array}{r}24.76 \\
2.53\end{array}$ & $\begin{array}{l}19.63 \\
11.36\end{array}$ & $\begin{array}{r}47.94 \\
6.94\end{array}$ \\
\hline
\end{tabular}

Neutralized stock solution with $360 \mathrm{mg} / \mathrm{L}$ total alkalinity $(\mathrm{RP}-7)$. 
TABLE A.6. MEAN CELL COUNTS $( \pm 1.0$ SO) IN ALGAL STIMULATION TESTS WITH RP-BR SMOKE-DOSED WATER

\begin{tabular}{|c|c|c|c|c|c|c|c|}
\hline \multirow{2}{*}{$\begin{array}{l}\text { Treatment } \\
(\% \text { sto }=k)\end{array}$} & \multirow{2}{*}{$\begin{array}{c}\mathrm{PO}_{4}^{3-} \\
(\mathrm{mg} / \mathrm{L})\end{array}$} & \multirow[b]{2}{*}{$\mathrm{pH}^{\mathrm{H}}$} & \multicolumn{5}{|c|}{ Mean Cell Count $\left(x \quad 10^{3} / \mathrm{mL}\right)$} \\
\hline & & & $0 \mathrm{hr}$ & $24 \mathrm{hr}$ & $48 \mathrm{hr}$ & $72 \mathrm{hr}$ & $96 \mathrm{hr}$ \\
\hline $\mathrm{NA}^{\mathrm{a}}$ & 0.28 & 7.46 & $\begin{array}{r}18.28 \\
4.29\end{array}$ & $\begin{array}{r}34.71 \\
4.22\end{array}$ & $\begin{array}{l}97.63 \\
24.39\end{array}$ & $\begin{array}{l}320.94 \\
151.84\end{array}$ & $\begin{array}{l}460.40 \\
170.30\end{array}$ \\
\hline NA ${ }^{b}$ & 0.69 & 7.50 & $\begin{array}{r}25.47 \\
6.27\end{array}$ & $\begin{array}{r}35.75 \\
2.85\end{array}$ & $\begin{array}{r}143.97 \\
20.54\end{array}$ & $\begin{array}{r}461.38 \\
84.81\end{array}$ & $\begin{array}{l}832.30 \\
209.17\end{array}$ \\
\hline 4.98 & 1.41 & 4.95 & $\begin{array}{r}25.40 \\
6.87\end{array}$ & $\begin{array}{r}19.07 \\
3.50\end{array}$ & $\begin{array}{r}18.36 \\
3.33\end{array}$ & $\begin{array}{r}19.37 \\
3.36\end{array}$ & $\begin{array}{r}13.02 \\
2.64\end{array}$ \\
\hline 3.27 & 1.13 & 5.20 & $\begin{array}{r}24.30 \\
3.64\end{array}$ & $\begin{array}{r}38.67 \\
5.58\end{array}$ & $\begin{array}{r}100.01 \\
21.30\end{array}$ & $\begin{array}{r}257.31 \\
81.77\end{array}$ & $\begin{array}{l}645.36 \\
254.75\end{array}$ \\
\hline 2.77 & 0.86 & 6.08 & $\begin{array}{r}15.61 \\
3.53\end{array}$ & $\begin{array}{r}20.06 \\
4.60\end{array}$ & $\begin{array}{r}158.31 \\
11.10\end{array}$ & $\begin{array}{r}416.72 \\
77.06\end{array}$ & $\begin{array}{r}1236.78 \\
152.55\end{array}$ \\
\hline 1.81 & 0.61 & 6.48 & $\begin{array}{r}16.92 \\
0.75\end{array}$ & $\begin{array}{r}34.34 \\
5.58\end{array}$ & $\begin{array}{r}123.09 \\
20.38\end{array}$ & $\begin{array}{r}427.25 \\
90.70\end{array}$ & $\begin{array}{r}1477.70 \\
127.30\end{array}$ \\
\hline 4.98 & 1.38 & 7.20 & $\begin{array}{l}28.85 \\
13.63\end{array}$ & $\begin{array}{l}48.55 \\
10.95\end{array}$ & $\begin{array}{r}156.90 \\
9.79\end{array}$ & $\begin{array}{r}477.47 \\
41.07\end{array}$ & $\begin{array}{r}1591.26 \\
162.85\end{array}$ \\
\hline 3.27 & 0.92 & 7.15 & $\begin{array}{r}23.18 \\
2.21\end{array}$ & $\begin{array}{r}40.20 \\
7.29\end{array}$ & $\begin{array}{r}177.79 \\
54.16\end{array}$ & $\begin{array}{l}477.83 \\
207.10\end{array}$ & $\begin{array}{r}1454.92 \\
83.28\end{array}$ \\
\hline 2.77 & 0.83 & 7.24 & $\begin{array}{r}20.91 \\
4.91\end{array}$ & $\begin{array}{l}46.55 \\
10.49\end{array}$ & $\begin{array}{r}139.03 \\
2.01\end{array}$ & $\begin{array}{r}410.24 \\
27.72\end{array}$ & $\begin{array}{r}1257.10 \\
205.85\end{array}$ \\
\hline 1.81 & 0.64 & 7.25 & $\begin{array}{r}23.05 \\
1.83\end{array}$ & $\begin{array}{l}43.29 \\
10.94\end{array}$ & $\begin{array}{r}135.44 \\
15.98\end{array}$ & $\begin{array}{r}466.36 \\
13.28\end{array}$ & $\begin{array}{r}1352.52 \\
89.76\end{array}$ \\
\hline
\end{tabular}

Not appticable, $\mathrm{PO}^{2}$-deficient contral.

bot applicable, complete media. 
TABLE A.7. MEAN CELL COUNTS $(\div 1.0$ SD) FOR SELENASTRUM CAPRICORNHTIM EXPOSED TO WP-F SMOKE-DOSED WATER

\begin{tabular}{|c|c|c|c|c|c|c|}
\hline \multirow{2}{*}{$\begin{array}{l}\text { Treatment } \\
\text { (s stock) }\end{array}$} & \multirow{2}{*}{$\begin{array}{r}\text { Total P } \\
(\mathrm{mg} / \mathrm{L}) \\
\end{array}$} & \multicolumn{5}{|c|}{ Mean Cel1 Count $\left(\times 10^{3} / \mathrm{mL}\right)$} \\
\hline & & $0 \mathrm{hr}$ & $24 \mathrm{hr}$ & $48 \mathrm{hr}$ & $72 \mathrm{hr}$ & $96 \mathrm{hr}$ \\
\hline 100 & 125 & $\begin{array}{r}11.56 \\
3.94\end{array}$ & $\begin{array}{l}7.44 \\
4.58\end{array}$ & $\begin{array}{r}10.40 \\
2.17\end{array}$ & $\begin{array}{l}8.35 \\
2.69\end{array}$ & $\begin{array}{l}22.71 \\
16.09\end{array}$ \\
\hline 6 & 7.6 & $\begin{array}{r}12.64 \\
2.91\end{array}$ & $\begin{array}{r}11.67 \\
6.60\end{array}$ & $\begin{array}{r}14.19 \\
7.96\end{array}$ & $\begin{array}{r}28.26 \\
7.81\end{array}$ & $\begin{array}{l}46.68 \\
35.38\end{array}$ \\
\hline 3 & 3.6 & $\begin{array}{r}12.79 \\
3.82\end{array}$ & $\begin{array}{l}8.25 \\
6.27\end{array}$ & $\begin{array}{l}25.71 \\
17.53\end{array}$ & $\begin{array}{l}163.19 \\
137.44\end{array}$ & $\begin{array}{l}663.80 \\
554.33\end{array}$ \\
\hline 1 & 1.8 & $\begin{array}{r}11.89 \\
1.40\end{array}$ & $\begin{array}{l}6.78 \\
3.15\end{array}$ & $\begin{array}{r}22.07 \\
6.24\end{array}$ & $\begin{array}{l}105.97 \\
114.22\end{array}$ & $\begin{array}{l}431.53 \\
482.24\end{array}$ \\
\hline 0.6 & 0.7 & $\begin{array}{r}13.44 \\
1.55\end{array}$ & $\begin{array}{l}7.98 \\
5.94\end{array}$ & $\begin{array}{l}21.64 \\
14.45\end{array}$ & $\begin{array}{r}86.90 \\
136.40\end{array}$ & $\begin{array}{l}256.06 \\
423.02\end{array}$ \\
\hline Control & $D^{a}$ & $\begin{array}{r}13.62 \\
2.25\end{array}$ & $\begin{array}{l}9.82 \\
0.43\end{array}$ & $\begin{array}{l}16.37 \\
12.51\end{array}$ & $\begin{array}{l}46.17 \\
59.14\end{array}$ & $\begin{array}{l}417.41 \\
687.94\end{array}$ \\
\hline $\begin{array}{c}\text { Neutral ized } \\
\text { Stock }\end{array}$ & 125 & $\begin{array}{r}14.24 \\
1.15\end{array}$ & $\begin{array}{r}9.20 \\
1.399\end{array}$ & $\begin{array}{r}16.01 \\
1.80\end{array}$ & $\begin{array}{r}16.74 \\
4.39\end{array}$ & $\begin{array}{r}20.03 \\
4.52\end{array}$ \\
\hline
\end{tabular}

Detection limits. 
TABLE A.8. MEAN CELL COUNTS $( \pm 1.0$ SD) IN ALGAL STIMULATION TESTS WITH WP-F SMOKED-DOSED WATER

\begin{tabular}{|c|c|c|c|c|c|c|c|}
\hline \multirow{2}{*}{$\begin{array}{l}\text { Treatment } \\
\text { (s stock) }\end{array}$} & \multirow{2}{*}{$\begin{array}{c}\mathrm{PO}_{4} \\
(\mathrm{mg} / \mathrm{L})\end{array}$} & \multirow[b]{2}{*}{$\mathrm{pH}$} & \multicolumn{5}{|c|}{ Means Ceil Count $\left(\times 10^{3} / \mathrm{mL}\right)$} \\
\hline & & & $0 \mathrm{hr}$ & $24 \mathrm{hr}$ & $48 \mathrm{hr}$ & $72 \mathrm{hr}$ & $96 \mathrm{hr}$ \\
\hline $\mathrm{NA}^{\mathrm{a}}$ & 0.20 & 7.5 & $\begin{array}{r}21.50 \\
2.33\end{array}$ & $\begin{array}{l}70.42 \\
16.16\end{array}$ & $\begin{array}{r}113.87 \\
28.10\end{array}$ & $\begin{array}{r}237.15 \\
54.91\end{array}$ & $\begin{array}{l}325.88 \\
129.81\end{array}$ \\
\hline$N A^{b}$ & -- & 7.38 & $\begin{array}{r}20.72 \\
3.18\end{array}$ & $\begin{array}{l}35.60 \\
12.44\end{array}$ & $\begin{array}{l}62.85 \\
36.86\end{array}$ & $\begin{array}{l}330.72 \\
176.56\end{array}$ & $\begin{array}{l}655.34 \\
277.49\end{array}$ \\
\hline 10 & 3.41 & 4.8 & $\begin{array}{r}23.79 \\
2.80\end{array}$ & $\begin{array}{r}21.36 \\
3.91\end{array}$ & $\begin{array}{r}13.81 \\
2.12\end{array}$ & $\begin{array}{r}16.82 \\
7.90\end{array}$ & $\begin{array}{l}24.04 \\
11.23\end{array}$ \\
\hline 7 & 2.85 & 5.5 & $\begin{array}{r}24.63 \\
2.12\end{array}$ & $\begin{array}{r}22.01 \\
2.46\end{array}$ & $\begin{array}{r}25.00 \\
2.71\end{array}$ & $\begin{array}{r}28.65 \\
8.63\end{array}$ & $\begin{array}{l}48.86 \\
36.07\end{array}$ \\
\hline 5.2 & 2.08 & 6.0 & $\begin{array}{r}23.10 \\
2.48\end{array}$ & $\begin{array}{l}34.00 \\
16.71\end{array}$ & $\begin{array}{l}69.03 \\
23.74\end{array}$ & $\begin{array}{r}189.86 \\
58.86\end{array}$ & $\begin{array}{l}494.47 \\
296.27\end{array}$ \\
\hline 2.4 & 0.89 & 6.6 & $\begin{array}{r}27.22 \\
7.86\end{array}$ & $\begin{array}{l}37.10 \\
16.00\end{array}$ & $\begin{array}{r}100.03 \\
24.11\end{array}$ & $\begin{array}{l}724.56 \\
271.06\end{array}$ & $\begin{array}{l}628.40 \\
291.39\end{array}$ \\
\hline 10 & 3.83 & 7.35 & $\begin{array}{r}24.49 \\
3.30\end{array}$ & $\begin{array}{r}24.30 \\
2.61\end{array}$ & $\begin{array}{r}103.01 \\
46.86\end{array}$ & $\begin{array}{r}323.37 \\
47.33\end{array}$ & $\begin{array}{l}504.27 \\
383.02\end{array}$ \\
\hline 7 & 2.70 & 7.35 & $\begin{array}{r}23.44 \\
3.48\end{array}$ & $\begin{array}{l}50.30 \\
23.64\end{array}$ & $\begin{array}{l}83.19 \\
23.64\end{array}$ & $\begin{array}{r}350.42 \\
26.45\end{array}$ & $\begin{array}{r}197.20 \\
90.23\end{array}$ \\
\hline 5.2 & 2.05 & 7.35 & $\begin{array}{r}25.73 \\
3.38\end{array}$ & $\begin{array}{r}42.72 \\
6.98\end{array}$ & $\begin{array}{r}121.68 \\
40.88\end{array}$ & $\begin{array}{l}542.18 \\
132.74\end{array}$ & $\begin{array}{l}237.74 \\
140.19\end{array}$ \\
\hline 2.4 & 1.20 & 7.35 & $\begin{array}{r}24.24 \\
1.79\end{array}$ & $\begin{array}{l}39.70 \\
12.02\end{array}$ & $\begin{array}{r}89.40 \\
12.62\end{array}$ & $\begin{array}{r}420.72 \\
39.38\end{array}$ & $\begin{array}{l}373.55 \\
150.06\end{array}$ \\
\hline
\end{tabular}

"Not applicable, $\mathrm{PO}_{4}^{3-}$ deficient control.

bot applicable, complete media. 
TABLE A.9. RESPONSE $( \pm 1.0$ SO) OF SELENASTRUH CAPRICORNITUM: TO RP-BR SHOKE DOSED WATER, CHLOROPITLLL DATA AT 48 AND 96 HR

\begin{tabular}{ccccr}
\hline \multirow{2}{*}{$\begin{array}{c}\text { Treatment } \\
\text { (8 stock) }\end{array}$} & $\begin{array}{c}\text { Total } \mathrm{P} \\
(\mathrm{mg} / \mathrm{L})\end{array}$ & $\mathrm{pH}$ & \multicolumn{2}{c}{ Chlorophyl A $(\mathrm{ng} / \mathrm{mL})$} \\
\hline 100 & 97 & $2.72^{\mathrm{a}}$ & $0.47 \pm 0.02$ & $96 \mathrm{hr}$ \\
10 & 9.3 & $5.03^{\mathrm{a}}$ & $1.56 \pm 0.07$ & $5.08 \pm 4.83$ \\
9 & 8.6 & $4.95^{\mathrm{a}}$ & $1.86 \pm 0.42$ & $5.28 \pm 5.11$ \\
7 & 6.1 & $5.0^{\mathrm{a}}$ & $1.71 \pm 0.27$ & $12.11 \pm 13.84$ \\
5 & 4.6 & $7.04^{\mathrm{a}}$ & $36.55 \pm 1.86$ & $736.30 \pm 42.02$ \\
1 & 1.0 & $7.76^{\mathrm{a}}$ & $13.76 \pm 7.37$ & $50.45 \pm 46.13$ \\
Control & $<0 \mathrm{~L}$ & 7.8 & $15.87 \pm 0.55$ & $19.88 \pm 4.98$ \\
$100^{\mathrm{C}}$ & 75 & 7.9 & $2.06 \pm 0.18$ & $2.41 \pm 1.20$ \\
\hline
\end{tabular}

${ }_{\mathrm{p}} \mathrm{pH}$ levels measured at end of test (RP-8).

Below detection Iimits.

Neutralized stock solution with $360 \mathrm{mg} / \mathrm{L}$ total alkalinity (RP-7).

TABLE A.10. RESPONSE ( $\pm 1.0 \mathrm{SD}$ ) OF SELENASTRUM CAPRICORNUTUM TO WNP-F SMOKE DOSED WATER, CHLOROPHYLL DATA AT 96 HR

\begin{tabular}{cccc}
\hline $\begin{array}{c}\text { Treatment } \\
\text { (gstock) }\end{array}$ & Total P & pH & $\frac{\text { Chiorophyl1 A }}{(\mathrm{ng} / \mathrm{mL})}$ \\
\hline 100 & 125 & 2.55 & $3.34 \pm 2.12$ \\
6 & 7.6 & 6.06 & $8.46 \pm 9.73$ \\
3 & 3.6 & 6.26 & $40.06 \pm 33.63$ \\
1 & 1.8 & 6.77 & $188.43 \pm 270.57$ \\
0.5 & 0.7 & 7.02 & $163.89 \pm 231.04$ \\
Control & $<\mathrm{DL}^{\mathrm{d}}$ & 7.44 & $12.81 \pm 13.80$ \\
1008 Neutralized & 125 & 7.32 & $0.78 \pm 0.13$ \\
\end{tabular}

Below detection limit. 
TABLE A.11. COMPARISON OF ALGAL TOXICITY OF THREE BATCHES OF SGF NO. 2 FOG OIL BASED ON MEAN CHLOROPHYLL ANALYSIS $( \pm 1.0$ SD) AT $96 \mathrm{HR}$

\begin{tabular}{|c|c|c|c|c|c|c|}
\hline \multirow[b]{2}{*}{$\begin{array}{l}\text { Treatment } \\
(8 \text { stock })\end{array}$} & \multicolumn{2}{|c|}{ Batch 1} & \multicolumn{2}{|c|}{ Batch 2} & \multicolumn{2}{|c|}{ Batch 3} \\
\hline & $\begin{array}{c}\text { Total } 0 i 1 \\
(m g / L)\end{array}$ & $\begin{array}{c}\text { Chlorophyll A } \\
\text { (ng/mL) } \\
96 \mathrm{hr} \\
\end{array}$ & $\begin{array}{c}\text { Total } 0 i 1 \\
(\mathrm{mg} / \mathrm{L})\end{array}$ & $\begin{array}{c}\text { Chlorophyl1 A } \\
(\mathrm{ng} / \mathrm{mL}) \\
96 \mathrm{hr}\end{array}$ & $\begin{array}{c}\text { Total } 0 i 1 \\
(\mathrm{mg} / \mathrm{L})\end{array}$ & $\begin{array}{c}\text { Chlorophyll A } \\
(\mathrm{ng} / \mathrm{mL}) \\
96 \mathrm{hr}\end{array}$ \\
\hline 100 & 3.23 & $45.52 \pm 12.18$ & 2.39 & $345.19 \pm 75.29$ & 3.47 & $223.71 \pm 33.7$ \\
\hline 60 & 2.15 & $37.78 \pm 32.45$ & 1.44 & $93.10 \pm 79.76$ & 2.75 & $207.12 \pm 30.92$ \\
\hline 40 & 1.66 & $126.97 \pm 33.83$ & 1.17 & $212.62 \pm 12.08$ & 2.56 & $171.44 \pm 11.81$ \\
\hline 20 & 0.95 & $184.54 \pm 59.12$ & 0.65 & $148.02 \pm 61.79$ & 1.07 & $216.99 \pm 225.79$ \\
\hline 10 & 0.07 & $278.81 \pm 170.81$ & 0.45 & $219.10 \pm 46.68$ & 0.61 & $175.86 \pm 102.70$ \\
\hline 5 & 0.76 & $261.38 \pm 33.00$ & 0.29 & $121.37 \pm 47.76$ & $--^{a}$ & $--\quad \quad--$ \\
\hline Control & 0.14 & $119.38 \pm 92.21$ & 0.20 & $146.25 \pm 61.66$ & 0.09 & $138.97 \pm 38.39$ \\
\hline
\end{tabular}


TABLE A.12. RESPONSES ( \pm 1.0 SD) OF SELENASTRUM CAPRICORNLTLM TO VAPORIZED FOG OIL, CHLOROPHYLL A DATA TAKEN AT 96 HR

\begin{tabular}{ccc}
\hline $\begin{array}{c}\text { Treatment } \\
\text { (8) stock) }\end{array}$ & $\begin{array}{c}\text { Totai } 0 i 1 \\
(\mathrm{mg} / \mathrm{L})\end{array}$ & $\begin{array}{c}\text { Chforophyl1 A } \\
(\mathrm{rgg} / \mathrm{mL})\end{array}$ \\
\hline 100 & $2.38 \pm 0.07$ & $53.91 \pm 17.52$ \\
60 & $1.48 \pm 0.06$ & $58.97 \pm 33.81$ \\
40 & $1.10 \pm 0.09$ & $48.97 \pm 8.15$ \\
20 & $0.76 \pm 0.07$ & $47.78 \pm 23.35$ \\
10 & $0.68 \pm 0.00$ & $64.89 \pm 10.21$ \\
0 & $0.18 \pm 0.02$ & $16.77 \pm 1.61$ \\
\hline
\end{tabular}


APPENDIX B

ALGAL MEDIA

TABLE B.1. MEDIA USED FOR TOXICITY TESTING (MILLER ET AL. 1978)

\begin{tabular}{|c|c|c|c|}
\hline Compound & $\begin{array}{c}\text { Concentration } \\
(\mathrm{mg} / \mathrm{L})\end{array}$ & Compound & $\begin{array}{c}\text { Concentration } \\
(\mathrm{g} / \mathrm{L})\end{array}$ \\
\hline $\mathrm{H}_{3} \mathrm{BO}_{3}$ & 185.520 & $\mathrm{NaNO}_{3}$ & 25.500 \\
\hline $\mathrm{MnCL}_{2} \cdot 4 \mathrm{H}_{2} \mathrm{O}$ & 415.610 & $\mathrm{NaHCO}_{3}$ & 15.000 \\
\hline $\ln \left[1_{2}\right.$ & 3.271 & $\mathrm{~K}_{2} \mathrm{HPO}_{4}$ & 1.044 \\
\hline $\mathrm{CoO}_{2} \cdot 6 \mathrm{H}_{2} \mathrm{O}$ & 1.428 & $\mathrm{MgSO}_{4} \cdot 7 \mathrm{H}_{2} \mathrm{O}$ & 14.700 \\
\hline $\mathrm{Cu}_{2} \mathrm{I}_{2}=2 \mathrm{H}_{2} \mathrm{O}$ & 0.012 & $\mathrm{MgCl}_{2} \cdot 6 \mathrm{H}_{2} \mathrm{O}$ & 12.164 \\
\hline $\mathrm{Na}_{2} \cdot \mathrm{MoO}_{4} \cdot 2 \mathrm{H}_{2} \mathrm{O}$ & 7.260 & $\mathrm{CaCl}_{2} \cdot 2 \mathrm{H}_{2} \mathrm{O}$ & 4.410 \\
\hline $\mathrm{FeCl}_{3} \cdot 6 \mathrm{H}_{2} \mathrm{O}$ & 160.000 & $\mathrm{Na}_{2}$ EDTA $\cdot 2 \mathrm{H}_{2} \mathrm{O}^{\mathrm{b}}$ & 300.000 \\
\hline \multicolumn{4}{|c|}{$\begin{array}{l}\text { Media prepared using the following steps: } \\
1 \text {. Add } 1 \mathrm{~mL} \text { of each of the } 15 \text { stock solutions in the order given to } \\
\text { approximately } 900 \mathrm{~mL} \text { of distifled or deionized water and then } \\
\text { dilute to } 1 \mathrm{~L} \text {. } \\
\text { 2. Adjust } \mathrm{pH} \text { to } 7.5 \pm 0.1 \text { with } 0.1 \mathrm{~N} \mathrm{NaOH} \text { or } \mathrm{HCl} \text {. } \\
{ }^{0} \text { Omit if test material is or contains a metal. }\end{array}$} \\
\hline
\end{tabular}


TABLE B.2. MEDIA USED TO GROW SELENASTRUM CAPRICORNUTUM TO FEED DAPHNIA MAGNA (NICHDLS AND BOLD 1965)

A. Macronutrients - prepare six separate stocks, add $10 \mathrm{~mL}$ each to a final volume of $1.0 \mathrm{~L}$.
1) $\mathrm{NaNO}_{3}$
$10 \mathrm{~g} / 400 \mathrm{~mL}$
2) $\mathrm{CaCl}_{2} \cdot 2 \mathrm{H}_{2} \mathrm{O}$
$1 \mathrm{~g} / 400 \mathrm{~mL}$
3) $\mathrm{MgSO}_{4} \cdot 7 \mathrm{H}_{2} \mathrm{O}$
$3 \mathrm{~g} / 400 \mathrm{~mL}$
4) $\mathrm{K}_{2} \mathrm{HPO}_{4}$
$3 \mathrm{~g} / 400 \mathrm{~mL}$
5) $\mathrm{KH}_{2} \mathrm{PO}_{4}$
$7 \mathrm{~g} / 400 \mathrm{~mL}$
6) $\mathrm{NaCl}$
$1 \mathrm{~g} / 400 \mathrm{~mL}$

B. Minor constituents - prepare three separate stocks, add $1 \mathrm{~mL}$ each to a $1.0 \mathrm{~L}$ of media.
1) EDTA
$50 \mathrm{~g} / \mathrm{L}$
$\mathrm{KOH}$
$31 \mathrm{~g} / \mathrm{L}$
2) $\mathrm{FeSO}_{4} \cdot 7 \mathrm{H}_{2} \mathrm{O}$
$\mathrm{H}_{2} \mathrm{SO}_{4}$
$4.98 \mathrm{~g} / \mathrm{L}$
$1.0 \mathrm{mi} / \mathrm{L}$
3) $\mathrm{H}_{3} \mathrm{BO}_{3}$
$11.42 \mathrm{~g} / \mathrm{L}$

C. Micronutrients - prepare one stock solution containing the following compounds, add $1.0 \mathrm{~mL}$ to $1.0 \mathrm{~L}$ media.
$\mathrm{ZnSO}_{4} \cdot 7 \mathrm{H}_{2} \mathrm{O}$
$8.82 \mathrm{~g} / \mathrm{L}$
$\mathrm{MnCL}_{2} \cdot 4 \mathrm{H}_{2} \mathrm{O}$
$1.44 \mathrm{~g} / \mathrm{L}$
$\mathrm{MoO}_{3}$
$0.71 \mathrm{~g} / \mathrm{L}$
$\mathrm{CuSO}_{4} \cdot 5 \mathrm{H}_{2} \mathrm{O}$
$1.57 \mathrm{~g} / \mathrm{L}$
$\mathrm{Co}\left(\mathrm{NO}_{3}\right)_{2} \cdot 6 \mathrm{H}_{2} \mathrm{O}$
$0.49 \mathrm{~g} / \mathrm{L}$ 
TABLE 8.2. (continued)

D. Vitamins - prepare one stock solution composed of the following vitamins, add $1.0 \mathrm{~mL}$ to $1.0 \mathrm{~L}$ media (Goulden et al. 1982).

$\begin{array}{ll}\text { Biotin } & 5 \mathrm{mg} / \mathrm{L} \\ \text { Thiamine } & 100 \mathrm{mg} / \mathrm{L} \\ \text { Pyridoxine } & 100 \mathrm{mg} / \mathrm{L} \\ \text { Pyridoxamine } & 3 \mathrm{mg} / \mathrm{L} \\ \text { Calcium pantothenate } & 250 \mathrm{mg} / \mathrm{L} \\ \text { B } 12 \text { (as 0.1\% mannitol) } & 100 \mathrm{mg} / \mathrm{L} \\ \text { Nicotinic Acid } & 50 \mathrm{mg} / \mathrm{L} \\ \text { Nicotinamide } & 50 \mathrm{mg} / \mathrm{L} \\ \text { Folic Acid } & 20 \mathrm{mg} / \mathrm{L} \\ \text { Riboflavin } & 30 \mathrm{mg} / \mathrm{L} \\ \text { Inositol } & 90 \mathrm{mg} / \mathrm{L}\end{array}$




\section{APPENDIX C \\ TOXICITY TEST DATA \\ PHOSPHORUS BASED OBSCURANTS}

This appendix contains summary data from toxicity tests conducted on this project. This information includes toxicant concentration, pH, daily mortality observations and, for fish tests, un-ionized $\mathrm{NH}_{3}$ values. Dissolved oxygen values did not fall below $5.0 \mathrm{mg} / \mathrm{L}$ except in the first. test with I. punctatus (Table C.13). Aeration was provided in that test after $72 \mathrm{~h} \bar{r}$ and for the duration of the second RP-BR test (Table C.12).

TABLE C.1. RP-BR NEUTRALIZATION TESTS VITH DAPHINIA MAGNA IN WELL WATER, BURN RP-5 (TOTAL $P=93 \mathrm{mg} / \mathrm{L}$ IN STOCK SOLUTION:)

\begin{tabular}{|c|c|c|c|c|c|}
\hline \multirow{2}{*}{ 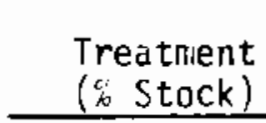 } & \multirow[b]{2}{*}{$\mathrm{pH}^{\mathrm{a}}$} & \multicolumn{4}{|c|}{ Mortality $(\%)$} \\
\hline & & $24 \mathrm{hr}$ & $48 \mathrm{hr}$ & $72 \mathrm{hr}$ & $06 \mathrm{hr}$ \\
\hline \multicolumn{6}{|l|}{ Meutralized } \\
\hline $\begin{array}{r}100 \\
70 \\
50 \\
40 \\
30 \\
10\end{array}$ & $\begin{array}{l}7.43 \\
7.76 \\
7.85 \\
8.04 \\
8.12 \\
8.24\end{array}$ & $\begin{array}{l}0 \\
0 \\
0 \\
0 \\
0 \\
0\end{array}$ & $\begin{array}{l}0 \\
0 \\
0 \\
0 \\
0 \\
0\end{array}$ & $\begin{array}{c}4.2 \\
0 \\
12.5 \\
20.8 \\
4.2 \\
0\end{array}$ & $\begin{array}{l}75 \\
12.5 \\
66.7 \\
62.5 \\
20.8 \\
0\end{array}$ \\
\hline \multicolumn{6}{|c|}{ Non-fieutralized } \\
\hline $\begin{array}{c}100 \\
70 \\
50 \\
40 \\
30 \\
10 \\
\text { Control }\end{array}$ & $\begin{array}{l}3.34 \\
5.47 \\
6.82 \\
7.48 \\
7.73 \\
8.06 \\
8.27\end{array}$ & $\begin{array}{c}100 \\
33.3 \\
0 \\
0 \\
0 \\
0 \\
0\end{array}$ & $\begin{array}{c}100 \\
91.7 \\
0 \\
0 \\
0 \\
0 \\
0\end{array}$ & $\begin{array}{c}100 \\
100 \\
4.2 \\
16.7 \\
0 \\
0 \\
0\end{array}$ & $\begin{array}{c}100 \\
100 \\
83.3 \\
79.2 \\
29.2 \\
0 \\
0\end{array}$ \\
\hline
\end{tabular}

$\mathrm{a}_{\mathrm{pH}}$ taken at $24 \mathrm{hr}$. 
TABLE C.2. RP-BR NEUTRALIZATION TESTS WITH DAPHNIA MAGNA IN RECONSTITUTED SOFT WATER, BURN RP-9 (TOTAL $P=70 \mathrm{mg} / \mathrm{L}$ IN STOCK SOLUTIONS)

\begin{tabular}{|c|c|c|c|c|c|}
\hline \multirow{2}{*}{$\begin{array}{l}\text { Treatment } \\
\left(\begin{array}{l}\text { or } \\
\text { s }\end{array}\right.\end{array}$} & \multirow{2}{*}{$\begin{array}{c}\text { Initial } \\
\mathrm{pH}\end{array}$} & \multicolumn{4}{|c|}{ Mortality $(\%)$} \\
\hline & & $24 \mathrm{hr}$ & $48 \mathrm{hr}$ & $72 \mathrm{hr}$ & $96 \mathrm{hr}$ \\
\hline \multicolumn{6}{|l|}{ Neutralized } \\
\hline $\begin{array}{r}100 \\
20 \\
10 \\
5 \\
2 \\
0\end{array}$ & $\begin{array}{l}7.25 \\
7.19 \\
7.25 \\
7.32 \\
7.37 \\
7.32\end{array}$ & $\begin{array}{r}45 \\
0 \\
0 \\
0 \\
0 \\
0\end{array}$ & $\begin{array}{r}100 \\
\mathrm{C} \\
0 \\
0 \\
0 \\
0\end{array}$ & $\begin{array}{r}100 \\
0 \\
0 \\
5 \\
0 \\
0\end{array}$ & $\begin{array}{r}100 \\
0 \\
0 \\
5 \\
0 \\
0\end{array}$ \\
\hline \multicolumn{6}{|c|}{ Non-Neutralized } \\
\hline $\begin{array}{r}100 \\
28 \\
10 \\
5 \\
2 \\
0\end{array}$ & $\begin{array}{l}2.92 \\
5.73 \\
6.44 \\
6.80 \\
7.04 \\
7.25\end{array}$ & $\begin{array}{r}100 \\
0 \\
0 \\
0 \\
0 \\
0\end{array}$ & $\begin{array}{r}100 \\
0 \\
0 \\
0 \\
0 \\
0\end{array}$ & $\begin{array}{r}100 \\
5 \\
0 \\
0 \\
0 \\
0\end{array}$ & $\begin{array}{r}100 \\
5 \\
0 \\
0 \\
0 \\
0\end{array}$ \\
\hline
\end{tabular}


TABLE C.3. RP-BR NEUTRALIZATION TEST WITH DAPHNIA MAGNA IN RECONSTITUTED HARD WATER, TEST 1 , EIIRN RP-15 TTOTAL $P=65.4 \mathrm{mg} / \mathrm{L}$ IN STOCK SOLUTION)

\begin{tabular}{|c|c|c|c|c|c|}
\hline \multirow{2}{*}{$\begin{array}{l}\text { Treatment } \\
(\% \text { stock }) \\
\end{array}$} & \multirow[b]{2}{*}{ Initial $\mathrm{pH}$} & \multicolumn{4}{|c|}{ Mortality $(\%)$} \\
\hline & & $24 \mathrm{hr}$ & $48 \mathrm{hr}$ & $72 \mathrm{hr}$ & $96 \mathrm{hr}$ \\
\hline \multicolumn{6}{|c|}{ Neutralized } \\
\hline $\begin{array}{r}100 \\
80 \\
60 \\
40 \\
20 \\
0\end{array}$ & $\begin{array}{l}8.14 \\
8.05 \\
8.19 \\
8.24 \\
8.28 \\
8.33\end{array}$ & $\begin{array}{l}0 \\
0 \\
0 \\
0 \\
0 \\
0\end{array}$ & $\begin{array}{l}0 \\
0 \\
0 \\
5 \\
0 \\
0\end{array}$ & $\begin{array}{r}10 \\
5 \\
0 \\
5 \\
0 \\
0\end{array}$ & $\begin{array}{r}20 \\
5 \\
G \\
15 \\
10 \\
25\end{array}$ \\
\hline \multicolumn{6}{|c|}{ Non-Neutralized } \\
\hline $\begin{array}{r}100 \\
80 \\
60 \\
40 \\
20 \\
0\end{array}$ & $\begin{array}{l}5.50 \\
6.47 \\
6.97 \\
7.28 \\
7.70 \\
8.26\end{array}$ & $\begin{array}{r}25 \\
0 \\
0 \\
0 \\
0 \\
0\end{array}$ & $\begin{array}{r}55 \\
5 \\
0 \\
0 \\
0 \\
0\end{array}$ & $\begin{array}{r}55 \\
20 \\
5 \\
5 \\
0 \\
5\end{array}$ & $\begin{array}{r}55 \\
25 \\
10 \\
5 \\
10 \\
5\end{array}$ \\
\hline
\end{tabular}


TABLE C.4. RP-GR NEUTRALIZATION TESTS WITH DAPHNIA MAGNA IN RECONSTITUTED HARD WATER, TEST 2, BURN RP-16 (TOTAL F $\equiv 69.1 \mathrm{mg} / \mathrm{L}$ IN STOCK SOLUTION)

\begin{tabular}{|c|c|c|c|c|c|}
\hline \multirow{2}{*}{$\begin{array}{l}\text { Treatment } \\
\langle \% \text { stock }\rangle\end{array}$} & \multirow[b]{2}{*}{ Initial $\mathrm{pH}$} & \multicolumn{4}{|c|}{ Mortality $(\%)$} \\
\hline & & $24 \mathrm{hr}$ & $48 \mathrm{hr}$ & $72 \mathrm{hr}$ & $96 \mathrm{hr}$ \\
\hline \multicolumn{6}{|c|}{ Neutralized } \\
\hline $\begin{array}{r}100 \\
70 \\
50 \\
30 \\
10\end{array}$ & $\begin{array}{l}7.96 \\
8.01 \\
8.08 \\
8.15 \\
8.17\end{array}$ & $\begin{array}{l}0 \\
0 \\
0 \\
0 \\
0\end{array}$ & $\begin{array}{l}0 \\
0 \\
0 \\
5 \\
0\end{array}$ & $\begin{array}{l}5 \\
0 \\
5 \\
5 \\
5\end{array}$ & $\begin{array}{r}15 \\
0 \\
5 \\
5 \\
5\end{array}$ \\
\hline \multicolumn{6}{|c|}{ Non-Neutralized } \\
\hline $\begin{array}{r}100 \\
70 \\
50 \\
30 \\
1 C \\
C\end{array}$ & $\begin{array}{l}4.70 \\
6.29 \\
6.76 \\
7.15 \\
7.70 \\
8.20\end{array}$ & $\begin{array}{r}95 \\
0 \\
0 \\
0 \\
0 \\
0\end{array}$ & $\begin{array}{r}100 \\
0 \\
0 \\
0 \\
0 \\
0\end{array}$ & $\begin{array}{r}100 \\
0 \\
0 \\
0 \\
0 \\
0\end{array}$ & $\begin{array}{r}100 \\
5 \\
0 \\
0 \\
0 \\
0\end{array}$ \\
\hline
\end{tabular}


TABLE C.5. FP-BR NEUTRALIZATION TESTS WITH DAPHNIA MAGNA IN RECONSTITUTED VERY HARD WATER, BURN RP-5 (TOTAL P $=96.3 \mathrm{mg} / L$ IN STOCK SOLUTION)

\begin{tabular}{|c|c|c|c|c|c|}
\hline \multirow{2}{*}{$\begin{array}{l}\text { Treatment } \\
(\% \text { Stock }) \\
\end{array}$} & \multirow[b]{2}{*}{$\mathrm{pH}$ at $24 \mathrm{hr}$} & \multicolumn{4}{|c|}{ Mortality $(\%)$} \\
\hline & & $24 \mathrm{hr}$ & $48 \mathrm{hr}$ & $72 \mathrm{hr}$ & $96 \mathrm{hr}$ \\
\hline \multicolumn{6}{|l|}{ Neutralized } \\
\hline $\begin{array}{r}100 \\
70 \\
50 \\
40 \\
30 \\
10\end{array}$ & $\begin{array}{l}7.80 \\
8.10 \\
8.22 \\
8.29 \\
8.40 \\
8.50\end{array}$ & $\begin{array}{l}0 \\
0 \\
0 \\
0 \\
0 \\
0\end{array}$ & $\begin{array}{l}0 \\
0 \\
0 \\
0 \\
0 \\
0\end{array}$ & $\begin{array}{c}12.5 \\
0 \\
8.3 \\
4.2 \\
4.2 \\
0\end{array}$ & $\begin{array}{l}25 \\
16.7 \\
25 \\
25 \\
16.7 \\
4.2\end{array}$ \\
\hline
\end{tabular}

Non-Neutralized

\begin{tabular}{cccccc}
100 & 7.13 & 0 & 0 & 37.5 & 91.7 \\
50 & 8.11 & 0 & 0 & 0 & 0 \\
40 & 8.22 & 0 & 0 & 4.2 & 8.3 \\
30 & 8.30 & 0 & 0 & 0 & 0 \\
10 & 8.47 & 0 & 0 & 0 & 0 \\
Controt $^{a}$ & 8.51 & 0 & 0 & 5.5 & 11.1 \\
\hline
\end{tabular}

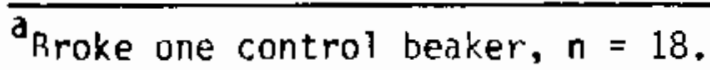

TABLE C.6. CUNULATIVE MORTALITY OF DAFHNIA MAGNA TO RP-BR SHOKE-DOSFD RIVER WATER, BURN RP-E

\begin{tabular}{|c|c|c|c|c|}
\hline \multirow{2}{*}{$\begin{array}{l}\text { Treatment } \\
(\% \text { Stock })^{\mathrm{a}} \\
\end{array}$} & \multirow{2}{*}{$\begin{array}{c}\text { Initial } \\
\mathrm{pH}\end{array}$} & \multirow{2}{*}{$\begin{array}{l}\text { Total P } \\
(\mathrm{mg} / \mathrm{L})\end{array}$} & \multicolumn{2}{|c|}{ Mortality $(\%)^{\mathrm{a}}$} \\
\hline & & & $24 \mathrm{hr}$ & $48 \mathrm{hr}$ \\
\hline 100 & 4.45 & 34.4 & 100 & 100 \\
\hline 90 & 5.23 & 30.7 & 60 & 80 \\
\hline 80 & 5.70 & 28.2 & 0 & 15 \\
\hline 70 & 6.05 & 23.8 & 0 & 0 \\
\hline 20 & 6.82 & 10.5 & 0 & 0 \\
\hline Control & 7.73 & $<1$ (b) & 0 & 0 \\
\hline
\end{tabular}

${ }^{a}$ Five instars per beaker, four beakers.

background levels. 
TABLE C.7. CUMULATYVE MURTALITY OF HYALLELA AZTECA TO RF-BR SHOK.F-DOSED RIVER. WATER, BURN RP-12

\begin{tabular}{|c|c|c|c|c|}
\hline Trea tment & Initial & Total P & \multicolumn{2}{|c|}{ Mortaity $(\%)^{\mathrm{a}}$} \\
\hline 91 & 3.26 & 60.6 & 100 & 100 \\
\hline 82 & 3.69 & 49.0 & 100 & 100 \\
\hline 62 & 3.84 & 42.1 & 100 & 100 \\
\hline 59 & 4.30 & 36.8 & 10 & 80 \\
\hline 40 & 6.98 & 24.0 & 0 & 0 \\
\hline Control & B. 04 & 0.16 & 0 & 0 \\
\hline
\end{tabular}

${ }^{\mathrm{a}}$ Twenty organisms per treatment.

TABLE C.8. ACUTE MORTALITY OF PARATANYTARSIJS DISSIMILUS TO RP-BR SMOKE-DOSED WATER, BURN RP-12

\begin{tabular}{|c|c|c|c|c|}
\hline $\begin{array}{l}\text { Trea tment } \\
\left(\begin{array}{l}o j \\
i 1\end{array} \text { Stock }\right)\end{array}$ & $\begin{array}{c}\text { Initial } \\
\mathrm{pH}\end{array}$ & $\begin{array}{r}\text { Total } P \\
(\mathrm{mg} / \mathrm{L}) \\
\end{array}$ & $\begin{array}{l}48-h r \\
\text { Mortality }\left(\begin{array}{l}(\alpha) \\
p\end{array}\right)\end{array}$ & Emergents $^{\mathrm{a}}$ \\
\hline 91 & 3.26 & 60.6 & 70 & 0 \\
\hline 82 & 3.69 & 49.0 & 20 & 1 \\
\hline 62 & 3.84 & 42.1 & 5 & 3 \\
\hline 59 & 4.37 & 36.8 & $E$ & 3 \\
\hline 40 & 6.98 & 24.0 & 0 & 1 \\
\hline Control & 8.04 & 0.16 & 0 & 1 \\
\hline
\end{tabular}

Assumed to be alive. 
TABLE C.9. CUMULATIVE MORTALITY OF HEXAGENIA EXPOSEO TO RP-BR SMOKE-DOSED RIVER WATER, BURN RP-13

\begin{tabular}{ccccc}
\hline $\begin{array}{c}\text { Treatment } \\
(\% \text { stock) }\end{array}$ & $\begin{array}{c}\text { Initial } \\
\mathrm{pH}\end{array}$ & $\begin{array}{c}\text { Total } \mathrm{P} \\
(\mathrm{mg} / \mathrm{L})\end{array}$ & \multicolumn{2}{c}{$\begin{array}{c}\text { Mortality }(\%) \\
24 \mathrm{hr}\end{array}$} \\
\hline 50 & 3.0 & 73.1 & 45 & 100 \\
35 & 3.43 & 50.7 & 15 & 100 \\
34 & $3.71-3.72$ & 45.5 & 10 & 100 \\
33 & $4.35-4.42$ & 39.1 & 5 & 10 \\
10 & 6.63 & 13.6 & 0 & 0 \\
Control & 7.92 & 0.20 & 0 & 0 \\
\hline
\end{tabular}

TABLE C.10. CUMULATIVE MORTALITY OF PIMEPHALES PROMELAS EXPOSED TO RP-BR SMOKE-DOSED RIVER WATER (10 FISH/AQUARTUM), BÜRN RP-10

\begin{tabular}{|c|c|c|c|c|c|c|c|}
\hline $\begin{array}{l}\text { Treatment } \\
\left(\begin{array}{ll}\% & \text { stock })^{\mathrm{a}}\end{array}\right.\end{array}$ & $\begin{array}{c}\text { Initial } \\
\mathrm{pH}\end{array}$ & $\begin{array}{l}\text { Total P } \\
(\mathrm{mg} / \mathrm{L})\end{array}$ & $24 \mathrm{hr}$ & Mortal & $\frac{i \operatorname{ty}(\%)}{72 \mathrm{hr}}$ & $96 \mathrm{hr}$ & $\begin{array}{c}96-\mathrm{hr} \mathrm{NH}_{3} \\
(\mu \mathrm{g} / \mathrm{L})\end{array}$ \\
\hline $\begin{array}{c}\text { Control } \\
\text { Control } \\
10.0 \\
10.0 \\
13.6 \\
13.6 \\
14.3 \\
14.3 \\
15.0 \\
15.0 \\
16.6 \\
16.6\end{array}$ & $\begin{array}{l}8.19 \\
8.46 \\
5.80 \\
5.76 \\
4.99 \\
5.41 \\
4.26 \\
4.65 \\
4.21 \\
4.32 \\
3.87 \\
3.86\end{array}$ & $\begin{array}{l}0.25 \\
0.37 \\
24.9 \\
22.9 \\
31.8 \\
33.0 \\
40.4 \\
36.8 \\
41.0 \\
39.9 \\
45.7 \\
45.3\end{array}$ & $\begin{array}{r}0 \\
0 \\
0 \\
0 \\
0 \\
0 \\
100 \\
10 \\
100 \\
100 \\
100 \\
100\end{array}$ & $\begin{array}{r}0 \\
0 \\
0 \\
0 \\
10 \\
0 \\
100 \\
40 \\
100 \\
100 \\
100 \\
100\end{array}$ & $\begin{array}{r}0 \\
0 \\
0 \\
0 \\
100 \\
80 \\
100 \\
100 \\
100 \\
100 \\
100 \\
100\end{array}$ & $\begin{array}{r}0 \\
0 \\
0 \\
0 \\
100 \\
80 \\
100 \\
100 \\
100 \\
100 \\
100 \\
100\end{array}$ & $\begin{array}{l}4.2 \\
4.3 \\
0.5 \\
0.4 \\
\text { ND } \\
0.3 \\
\text { ND } \\
\text { ND } \\
\text { ND } \\
\text { ND } \\
\text { ND } \\
\text { ND }\end{array}$ \\
\hline
\end{tabular}


TABLE C.11. CUMULATIVE MORTALITY OF SALMO GAIRDNERI EXPOSED TO RP-BR SMOKE-DOSED RIVER WATER, BURN RP-16

\begin{tabular}{|c|c|c|c|c|c|c|c|}
\hline $\begin{array}{l}\text { Treatment } \\
(\% \text { stock })^{\mathrm{a}}\end{array}$ & Initial pH & $\begin{array}{l}\text { Total p } \\
\text { (mg/L) }\end{array}$ & $24 \mathrm{hr}$ & $48 \mathrm{hr}$ & $72 \mathrm{hr}$ & $96 \mathrm{hr}$ & $\begin{array}{c}96-\mathrm{hr} \mathrm{NH}_{3} \\
(\mu \mathrm{g} / \mathrm{L})\end{array}$ \\
\hline $\begin{array}{c}25 \\
20 \\
18 \\
15 \\
10 \\
\text { Control }\end{array}$ & $\begin{array}{l}3.43,3.65 \\
4.31,4.31 \\
4.61,4.86 \\
5.45,5.52 \\
5.96,6.06 \\
7.68,7.75\end{array}$ & $\begin{array}{c}50.1,51.0 \\
40.7,40.9 \\
35.7,40.8 \\
29.6 \\
22.1,22.2 \\
0.13\end{array}$ & $\begin{array}{r}100 \\
0 \\
0 \\
0 \\
0 \\
0\end{array}$ & $\begin{array}{r}100 \\
25 \\
0 \\
0 \\
0 \\
0\end{array}$ & $\begin{array}{r}100 \\
75 \\
0 \\
0 \\
0 \\
0\end{array}$ & $\begin{array}{r}100 \\
85 \\
5 \\
0 \\
0 \\
0\end{array}$ & $\begin{array}{c}N D^{\mathrm{Z}} \\
0.1-0.2 \\
0.1-0.2 \\
0.1-0.5 \\
0.7-1.2 \\
2.5-4.5\end{array}$ \\
\hline
\end{tabular}

Not determined.

TABLE C.12. CUMULATIVE MORTALITY OF ICTALURUS PUNCTATUS EXPOSED TO RP-BR SMOKE-DOSED WATER, BURN RP-11 (TEST REPEATED)

\begin{tabular}{|c|c|c|c|c|c|c|c|}
\hline \multirow{2}{*}{$\begin{array}{l}\text { Treatment } \\
(\% \text { stock })\end{array}$} & \multirow{2}{*}{$\begin{array}{c}\text { Initial } \\
\mathrm{pH} \\
\end{array}$} & \multirow{2}{*}{$\begin{array}{l}\text { Tota i P } \\
(m g / L)\end{array}$} & \multicolumn{4}{|c|}{ Mortality $(\%)^{\mathrm{b}}$} & \multirow{2}{*}{$\begin{array}{c}96-\mathrm{hr} \mathrm{NH_{3 }} \\
(\mu \mathrm{g} / \mathrm{L})\end{array}$} \\
\hline & & & $24 \mathrm{hr}$ & $48 \mathrm{hr}$ & $72 \mathrm{hr}$ & $96 \mathrm{hr}$ & \\
\hline $\begin{array}{l}25.2 \\
21.1 \\
18.9 \\
14.3 \\
\text { Control }\end{array}$ & $\begin{array}{l}3.42,3.46 \\
4.08,4.13 \\
4.68,4.69 \\
5.52,5.68 \\
7.93,8.00\end{array}$ & $\begin{array}{l}49.9 \\
41.7 \\
37.5 \\
28.3 \\
0.16\end{array}$ & $\begin{array}{l}43.8 \\
0 \\
6.3 \\
0 \\
0\end{array}$ & $\begin{array}{c}100 \\
0 \\
6.3 \\
0 \\
0\end{array}$ & $\begin{array}{l}100 \\
0 \\
6.3 \\
0 \\
0\end{array}$ & $\begin{array}{c}100 \\
0 \\
6.3 \\
0 \\
0\end{array}$ & $\begin{array}{l}<0.1-0.5 \\
\quad<0.1 \\
<0.1 \\
9.0-1.0 \\
18.2-23.2\end{array}$ \\
\hline
\end{tabular}

Values for duplicate aquaria.

Sikteen fish per treatment. 
TABLE C.13. CUMULATIVE MORTALITY OF LEPOMIS MACROCHIRUS EXPOSEO TO RP-BR SHOKE-COOSEO WATER, BURN RP-12

\begin{tabular}{|c|c|c|c|c|c|c|c|c|}
\hline $\begin{array}{l}\text { Treatment } \\
(\% \text { stock }) \\
\end{array}$ & $\begin{array}{c}\text { Initial } \\
\mathrm{pH} \\
\end{array}$ & $\begin{array}{l}\text { Total P } \\
(\mathrm{mg} / \mathrm{L})\end{array}$ & $2 \overline{4-h r}$ & $\frac{\text { Morta }}{48-h r}$ & $\frac{i t y(\%)}{72-h r}$ & $96-h r$ & $\begin{array}{c}\text { 96-hr } \\
\text { Combined }\end{array}$ & $\begin{array}{c}96-\mathrm{hr} \\
\mathrm{PH} \mathrm{H}_{3} \\
(\mu \mathrm{g} / \mathrm{L})\end{array}$ \\
\hline $\begin{array}{c}\text { Control } \\
\text { Control } \\
5 \\
5 \\
7 \\
7 \\
8 \\
8 \\
9 \\
9 \\
11 \\
11\end{array}$ & $\begin{array}{l}7.8 \\
7.83 \\
5.60 \\
5.54 \\
4.19 \\
4.20 \\
3.71 \\
3.68 \\
3.49 \\
3.44 \\
3.23 \\
3.22\end{array}$ & $\begin{array}{c}0.3 \\
0.14 \\
26.6 \\
27.1 \\
37.9 \\
37.6 \\
31.6 \\
43.1 \\
48.5 \\
49.3 \\
59.1 \\
58.9\end{array}$ & $\begin{array}{r}0 \\
0 \\
0 \\
0 \\
0 \\
0 \\
100 \\
80 \\
100 \\
100 \\
100 \\
100\end{array}$ & $\begin{array}{r}0 \\
0 \\
0 \\
0 \\
10 \\
0 \\
100 \\
100 \\
100 \\
100 \\
100 \\
100\end{array}$ & $\begin{array}{r}0 \\
20 \\
0 \\
0 \\
10 \\
0 \\
100 \\
100 \\
100 \\
100 \\
100 \\
100\end{array}$ & $\begin{array}{r}0 \\
20 \\
0 \\
0 \\
10 \\
0 \\
100 \\
100 \\
100 \\
100 \\
100 \\
100\end{array}$ & 100 & $\begin{array}{l}2.42 \\
2.42 \\
0.05 \\
0.03 \\
0.04 \\
0.03 \\
110 \\
\mathrm{ND} \\
\mathrm{NO} \\
\mathrm{HO} \\
\mathrm{ND} \\
\mathrm{HD}\end{array}$ \\
\hline
\end{tabular}


TABI.E C.14. NEUTRALIZATION TEST WITH DAPHNIA MAGNA IN WELL WATER, ELRN WP-4 (TOTAL $P=66.4 \mathrm{mg} / \mathrm{L}$ IN STOCK SOLUTION)

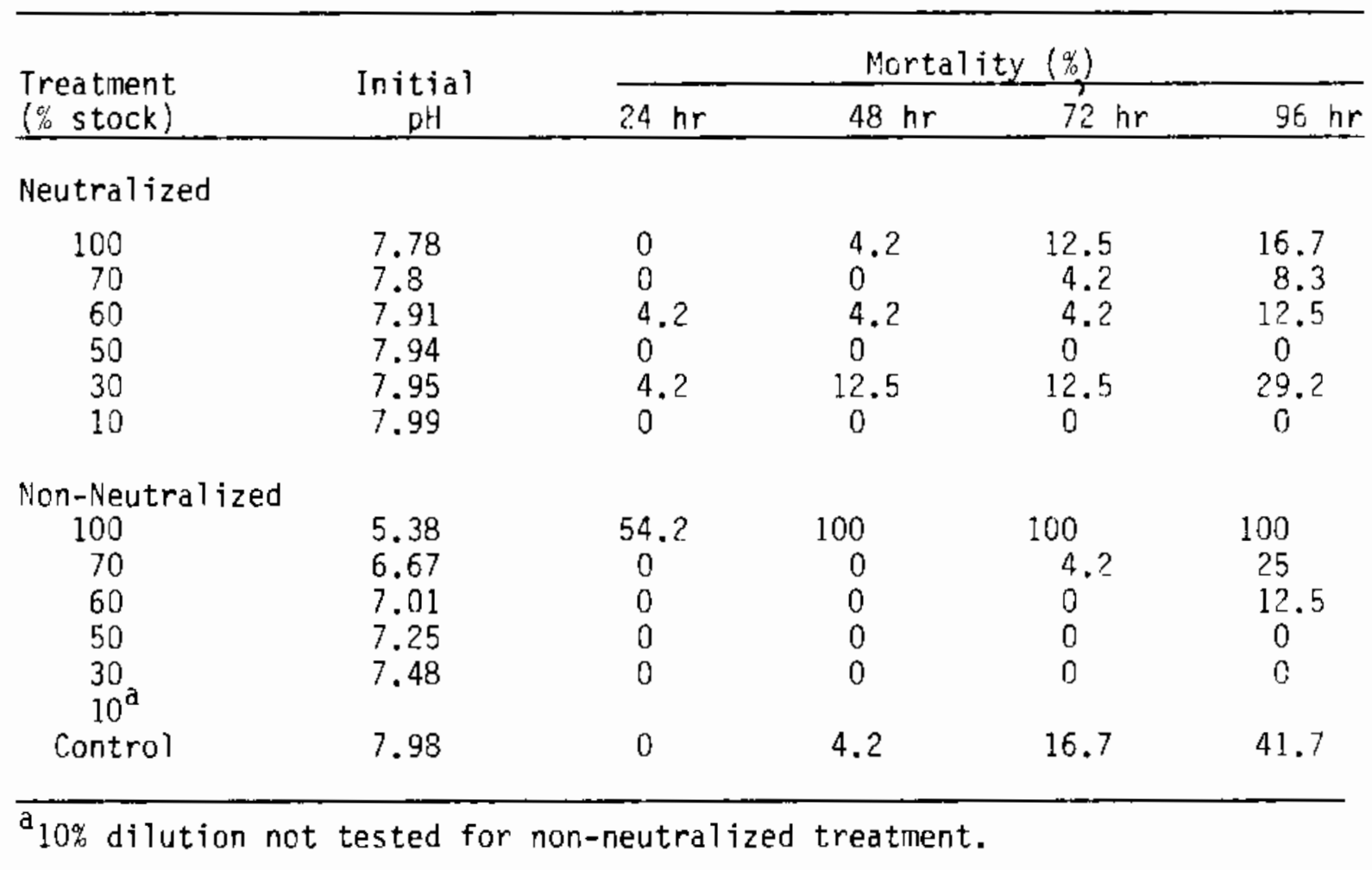


TABLE C. 15. WP-F NEUTRALIZATION TEST WITH DAPHNIA MAGNA IN RECONSTITUTEO SOFT WATER, BURN WP-4 (TOTAL $P=\overline{66.4} \mathrm{mg} / \mathrm{L}$ IN STOCK SOLUTION)

\begin{tabular}{|c|c|c|c|c|c|}
\hline \multirow{2}{*}{$\begin{array}{l}\text { Treatment } \\
(\% \text { stock }) \\
\end{array}$} & \multicolumn{4}{|c|}{ Mortality $(\%)$} & \multirow[b]{2}{*}{$96 \mathrm{hr}$} \\
\hline & $\mathrm{pH}$ & $24 \mathrm{hr}$ & $48 \mathrm{hr}$ & $72 \mathrm{hr}$ & \\
\hline \multicolumn{6}{|c|}{ Neutralized } \\
\hline $\begin{array}{r}100 \\
70 \\
50 \\
40 \\
30 \\
10\end{array}$ & $\begin{array}{l}7.69 \\
7.48 \\
7.47 \\
7.48 \\
7.50 \\
6.54\end{array}$ & $\begin{array}{r}38 \\
0 \\
0 \\
0 \\
0 \\
0\end{array}$ & $\begin{array}{r}88 \\
0 \\
4 \\
0 \\
0 \\
0\end{array}$ & $\begin{array}{r}100 \\
8 \\
4 \\
0 \\
0 \\
0\end{array}$ & $\begin{array}{r}100 \\
25 \\
4 \\
4 \\
4 \\
0\end{array}$ \\
\hline \multicolumn{6}{|c|}{ Non-Neutralized } \\
\hline $\begin{array}{c}100 \\
70 \\
50 \\
40 \\
30 \\
10 \\
1.0 \\
\text { Control }\end{array}$ & $\begin{array}{l}2.90 \\
3.10 \\
3.38 \\
3.71 \\
4.71 \\
6.63 \\
7.62 \\
7.98\end{array}$ & $\begin{array}{r}100 \\
100 \\
100 \\
100 \\
100 \\
0 \\
0 \\
0\end{array}$ & $\begin{array}{r}100 \\
100 \\
100 \\
100 \\
100 \\
0 \\
0 \\
0\end{array}$ & $\begin{array}{r}100 \\
100 \\
100 \\
100 \\
100 \\
0 \\
0 \\
0\end{array}$ & $\begin{array}{r}100 \\
100 \\
100 \\
100 \\
100 \\
0 \\
0 \\
3\end{array}$ \\
\hline
\end{tabular}


TABLE C.16. WP-F NEUTRALIZATION TESTS WITH DAPHNIA MAGNA IN RECONSTITUTED HARD WATER, BURN WP-10 (TOTAL $P=88.6 \mathrm{mg} / \mathrm{L}$ IN STOCK SOLUTION)

\begin{tabular}{|c|c|c|c|c|c|}
\hline \multirow{2}{*}{$\begin{array}{l}\text { Treatment } \\
(\% \text { stock) }\end{array}$} & \multirow[b]{2}{*}{$\mathrm{pH}$} & \multicolumn{4}{|c|}{ MortaTity (\%) } \\
\hline & & $24 \mathrm{hr}$ & $48 \mathrm{hr}$ & $72 \mathrm{hr}$ & $96 \mathrm{hr}$ \\
\hline \multicolumn{6}{|c|}{ Neutralized } \\
\hline $\begin{array}{r}100 \\
80 \\
60 \\
40 \\
20 \\
0\end{array}$ & $\begin{array}{l}7.97 \\
7.98 \\
8.00 \\
8.06 \\
8.04 \\
8.19\end{array}$ & $\begin{array}{r}20 \\
0 \\
5 \\
0 \\
0 \\
0\end{array}$ & $\begin{array}{r}40 \\
5 \\
10 \\
5 \\
0 \\
0\end{array}$ & $\begin{array}{r}45 \\
5 \\
10 \\
10 \\
0 \\
0\end{array}$ & $\begin{array}{r}50 \\
10 \\
25 \\
25 \\
15 \\
5\end{array}$ \\
\hline \multicolumn{6}{|c|}{ Non-Neutralized } \\
\hline $\begin{array}{r}00 \\
80 \\
60 \\
40 \\
20 \\
0\end{array}$ & $\begin{array}{l}3.08 \\
3.31 \\
3.91 \\
5.99 \\
6.78 \\
8.14\end{array}$ & $\begin{array}{r}100 \\
100 \\
100 \\
0 \\
0 \\
0\end{array}$ & $\begin{array}{r}100 \\
100 \\
100 \\
10 \\
5 \\
0\end{array}$ & $\begin{array}{r}100 \\
100 \\
100 \\
15 \\
10 \\
10\end{array}$ & $\begin{array}{r}100 \\
100 \\
100 \\
20 \\
10 \\
15\end{array}$ \\
\hline
\end{tabular}


TABLE C.17. WP-F NEUTRALIZATION TEST WITH DAPHNIA MAGNA IN RECONSTITUTED VERY HARD WATER, BURN WP-7 (TOTAL P $=125 \mathrm{mg} / \mathrm{L}$ IN STOCK SOLUTION)

\begin{tabular}{|c|c|c|c|c|c|}
\hline \multirow{2}{*}{$\begin{array}{l}\text { Treatment } \\
(\% \text { Stock })\end{array}$} & \multirow{2}{*}{$\begin{array}{c}\text { Initial } \\
\mathrm{pH}\end{array}$} & \multicolumn{4}{|c|}{ Mortality $(\%)$} \\
\hline & & $24 \mathrm{hr}$ & $48 \mathrm{hr}$ & $72 \mathrm{hr}$ & $96 \mathrm{hr}$ \\
\hline \multicolumn{6}{|c|}{ Neutralized } \\
\hline $\begin{array}{r}100 \\
70 \\
50 \\
30 \\
10\end{array}$ & $\begin{array}{l}8.08 \\
8.31 \\
8.47 \\
8.58 \\
8.64\end{array}$ & $\begin{array}{l}0 \\
5 \\
5 \\
0 \\
5\end{array}$ & $\begin{array}{r}30 \\
10 \\
5 \\
0 \\
15\end{array}$ & $\begin{array}{r}65 \\
25 \\
40 \\
5 \\
25\end{array}$ & $\begin{array}{l}80 \\
40 \\
50 \\
25 \\
40\end{array}$ \\
\hline \multicolumn{6}{|c|}{ Non-Neutralized } \\
\hline $\begin{array}{c}100 \\
70 \\
50 \\
30 \\
10 \\
\text { Control }\end{array}$ & $\begin{array}{l}4.99 \\
6.55 \\
7.04 \\
7.52 \\
8.66\end{array}$ & $\begin{array}{r}90 \\
0 \\
0 \\
0 \\
0 \\
0\end{array}$ & $\begin{array}{r}100 \\
0 \\
0 \\
5 \\
0 \\
0\end{array}$ & $\begin{array}{r}-- \\
30 \\
5 \\
5 \\
5 \\
0\end{array}$ & $\begin{array}{r}-- \\
55 \\
20 \\
5 \\
10 \\
0\end{array}$ \\
\hline
\end{tabular}


TABLE C.18. CUMULATIVE MORTALITY OF DAPHNIA MAGNA TO WP-F SHOKE-DOSED RIVER WATER, $\overline{\text { BURN WP-16 }}$

\begin{tabular}{|c|c|c|c|c|}
\hline \multirow{2}{*}{$\begin{array}{l}\text { Treatment } \\
(\% \text { stock })\end{array}$} & \multirow{2}{*}{$\begin{array}{c}\text { Initial } \\
\mathrm{pH}\end{array}$} & \multirow{2}{*}{$\begin{array}{l}\text { Tota! P } \\
(\mathrm{mg} / \mathrm{L})\end{array}$} & \multicolumn{2}{|c|}{ Mortality $(\%)$} \\
\hline & & & $24 \mathrm{hr}$ & $48 \mathrm{hr}$ \\
\hline $\begin{array}{l}25 \\
23.5 \\
20.9 \\
18.75 \\
15 \\
\text { Control }\end{array}$ & $\begin{array}{l}4.48 \\
5.22 \\
5.48 \\
5.82 \\
6.15 \\
8.6\end{array}$ & $\begin{array}{r}34.4 \\
30.7 \\
28.2 \\
23.8 \\
10.5 \\
\text { (bkg) }\end{array}$ & $\begin{array}{r}100 \\
55 \\
10 \\
0 \\
0 \\
0\end{array}$ & $\begin{array}{r}100 \\
60 \\
45 \\
35 \\
30 \\
0\end{array}$ \\
\hline
\end{tabular}

TABLE C.19. MORTALITY OF HYALLELA AZTECA EXPOSED TO WP-F SMOKE-DOSED RIVER WATER, BURN WP-14

\begin{tabular}{|c|c|c|c|c|}
\hline \multirow{2}{*}{$\begin{array}{l}\text { Treatment } \\
\text { (of stock) }\end{array}$} & \multirow{2}{*}{$\begin{array}{c}\text { Initial } \\
\mathrm{pH}\end{array}$} & \multirow{2}{*}{$\begin{array}{l}\text { Total P } \\
\text { (mg/L) }\end{array}$} & \multicolumn{2}{|c|}{ Mortality $(i)$} \\
\hline & & & $24 \mathrm{hr}$ & $48 \mathrm{hr}$ \\
\hline $\begin{array}{c}10.3 \\
8.1 \\
7.9 \\
7.2 \\
6.0 \\
\text { Control }\end{array}$ & $\begin{array}{l}3.5 \\
4.31 \\
4.51 \\
4.99 \\
5.5 \\
7.66\end{array}$ & $\begin{array}{l}44.4 \\
34.6 \\
33.8 \\
30.9 \\
26.2 . \\
(\mathrm{Bkg})\end{array}$ & $\begin{array}{r}100 \\
5 \\
5 \\
0 \\
0 \\
0\end{array}$ & $\begin{array}{r}100 \\
55 \\
55 \\
5 \\
5 \\
0\end{array}$ \\
\hline
\end{tabular}


TABLE C.20. MORTALITY AND CASE BUILDINC DATA FOR PARATANYTAPSIIS DISSIMILUS EXFOSED TO WP-F SHOKE-DOSED RIVER WATER, BURN WP-14

\begin{tabular}{ccccc}
$\begin{array}{c}\text { Treatnent } \\
\text { (\% stock) }\end{array}$ & Initial pH & Total P & $\begin{array}{c}\text { Mortality }(\%) \\
48 \text { hr }\end{array}$ & $\begin{array}{c}\text { Case Building } \\
\text { (total number os } \\
\text { tubes) }\end{array}$ \\
\hline 17.8 & 2.91 & 76.4 & 100 & 0 \\
12.7 & 3.21 & 54.9 & 95 & 3 \\
10.3 & 3.50 & 44.4 & 88 & 10 \\
8.7 & 3.99 & 37.2 & 0 & 26 \\
6.1 & 5.53 & 26.2 & 0 & 23 \\
0 & 7.66 & $(B \mathrm{~kg})$ & 0 & 20 \\
\hline
\end{tabular}

TABLE C.2. CUMULATIVE MORTALITY OF HEXAGENIA EXPOSED TO WP-F SHOKE-MOSED WATER, BURN WP-15

\begin{tabular}{ccccr}
\hline & & & \multicolumn{2}{c}{ Mortality $(g)$} \\
\cline { 3 - 5 } $\begin{array}{c}\text { Treatment } \\
(\% \text { stock })\end{array}$ & Initial pH $(\mathrm{a})$ & $\begin{array}{c}\text { Total } \mathrm{P} \\
(\mathrm{mg} / \mathrm{L})\end{array}$ & $24 \mathrm{hr}$ & $48 \mathrm{hr}$ \\
\hline 12 & $3.50,3.59$ & 49.6 & 20 & 100 \\
11 & $3.80,3.82$ & 46.6 & 10 & 30 \\
10 & $4.14,4.33$ & 41.7 & 5 & 5 \\
9 & $4.79,4.95$ & 37.5 & 0 & 5 \\
7 & $6.02,6.16$ & 29.2 & 0 & 0 \\
Control & $7.76,7.93$ & 0.83 & & 0 \\
\hline
\end{tabular}


TARLE C.22. CUMULATIVE MORTALITY OF PIMEPHALES PP.OMELAS EXPOSED TO WP-F SMOKE-DOSED RIVER WATER, BURN WP-14

\begin{tabular}{|c|c|c|c|c|c|c|c|}
\hline \multirow{2}{*}{$\begin{array}{l}\text { Treatment } \\
(\% \text { stock })\end{array}$} & \multirow[b]{2}{*}{ Initial pl: } & \multirow{2}{*}{$\begin{array}{l}\text { Total P } \\
(\mathrm{mg} / \mathrm{L})\end{array}$} & \multicolumn{4}{|c|}{ llortality $(\%)$} & \multirow{2}{*}{$\begin{array}{c}\mathrm{NH}_{3} \\
(\mu \mathrm{g} / \mathrm{L})\end{array}$} \\
\hline & & & $24 \mathrm{hr}$ & $48 \mathrm{hr}$ & $72 \mathrm{hr}$ & $96 \mathrm{hr}$ & \\
\hline 10 & $3.69,3.87$ & 44.5 & 100 & 100 & 100 & 100 & $N 0^{b}$ \\
\hline 9 & $4.02,4.04$ & 40.8 & 100 & 100 & 100 & 100 & NO \\
\hline 8 & $4.65,4.74$ & 35.1 & 0 & 0 & 0 & $15^{\mathrm{C}}$ & 0.06 \\
\hline 6 & $5.61,5.85$ & 27.3 & 0 & 0 & 0 & 0 & 0.07 \\
\hline 5 & $6.02,6.03$ & 22.7 & 0 & 0 & 0 & 0 & 0.10 \\
\hline Control & $7.93,7.95$ & (Bkg) & 0 & 0 & 0 & 0 & 1.21 \\
\hline
\end{tabular}

aviues for duplicate aquaria.

Not determined.

Three fish showed loss of equilibrium.

TABLE C.23. CUMULATIVE MORTALITY OF SALMO GAIRONERI EXPOSED TU LF-F SMOKE-DOSED RIVER WATER, BLR! WP-15

\begin{tabular}{|c|c|c|c|c|c|c|c|}
\hline \multirow{2}{*}{$\begin{array}{l}\text { Treatment } \\
(\% \text { Stock })\end{array}$} & \multirow[b]{2}{*}{ Initial $\mathrm{pH}^{\mathrm{a}}$} & \multirow{2}{*}{$\begin{array}{c}\text { Tota } 1 p^{\mathrm{a}} \\
(\mathrm{mg} / \mathrm{L})\end{array}$} & \multicolumn{4}{|c|}{ Mortality $(\%)$} & \multirow{2}{*}{$\begin{array}{c}96-\mathrm{hr} \quad \mathrm{NH}_{3} \\
(\mu \mathrm{g} / \mathrm{L}) \\
\end{array}$} \\
\hline & & & $24 h r$ & $48 \mathrm{hr}$ & $72 \mathrm{hr}$ & $96 \mathrm{hr}$ & \\
\hline $\begin{array}{c}12 \% \\
10 \% \\
9 \% \\
2 \% \\
7 \% \\
\text { Control }\end{array}$ & $\begin{array}{l}3.57-3.60 \\
4.13-4.19 \\
4.63-4.77 \\
5.23-5.26 \\
5.47-5.51 \\
7.67-7.72\end{array}$ & $\begin{array}{l}49.1,49.8 \\
41.5,41.5 \\
36.4,37.2 \\
32.6,32.7 \\
28.3,28.4 \\
0.2\end{array}$ & $\begin{array}{r}100 \\
100 \\
50 \\
25 \\
0 \\
0\end{array}$ & $\begin{array}{r}100 \\
100 \\
65 \\
25 \\
0 \\
0\end{array}$ & $\begin{array}{r}100 \\
100 \\
100 \\
25 \\
0 \\
0\end{array}$ & $\begin{array}{r}100 \\
100 \\
100 \\
30 \\
0 \\
0\end{array}$ & $\begin{array}{c}\mathrm{ND}(\mathrm{b}) \\
\mathrm{ND} \\
<0.1-0.1 \\
<0.1 \\
0.2-0.3 \\
8.5-9.7\end{array}$ \\
\hline
\end{tabular}


TABLE C.24. MORTALITY OF ICTALURUS PUNCTATIIS TO WP-F SMOKEO-DOSED RIVER WATER, BURN WP-13

\begin{tabular}{|c|c|c|c|c|c|c|c|c|}
\hline \multirow{2}{*}{$\begin{array}{l}\text { Treatmerst } \\
(\% \text { stock }) \\
\end{array}$} & \multicolumn{2}{|c|}{$\mathrm{pH}$} & \multirow{2}{*}{$\begin{array}{l}\text { Tota i P } \\
(\mathrm{mg} / \mathrm{L})\end{array}$} & \multicolumn{4}{|c|}{ Mortality $(\%)$} & \multirow{2}{*}{$\begin{array}{c}96-\mathrm{hr} \mathrm{NH}_{3} \\
\left(\mathrm{Hg} \mathrm{g}^{\prime} \mathrm{L}\right) \\
\end{array}$} \\
\hline & Initial & $26 \mathrm{hr}$ & & $24 \mathrm{hr}$ & $48 \mathrm{hr}$ & $72 \mathrm{hr}$ & $96 \mathrm{hr}$ & \\
\hline $\begin{array}{c}10 \\
9 \\
8 \\
7 \\
5 \\
\text { Control }\end{array}$ & $\begin{array}{l}3.31 \\
3.50 \\
3.78 \\
4.28 \\
5.55 \\
7.77\end{array}$ & $\begin{array}{l}3.34 \\
3.52 \\
3.99 \\
5.08 \\
6.74 \\
8.02\end{array}$ & $\begin{array}{r}59.7 \\
53.3 \\
44.5 \\
40.3 \\
27.3 \\
0.1\end{array}$ & $\begin{array}{r}100 \\
100 \\
5 \\
5 \\
0 \\
0\end{array}$ & $\begin{array}{r}100 \\
100 \\
55 \\
10 \\
0 \\
0\end{array}$ & $\begin{array}{r}100 \\
100 \\
100 \\
15 \\
0 \\
0\end{array}$ & $\begin{array}{r}100 \\
100 \\
100 \\
15 \\
0 \\
0\end{array}$ & $\begin{array}{c}N D^{\mathrm{a}} \\
\mathrm{ND} \\
<0.1 \\
<0.1 \\
1.2=0.21 \\
23.0-24.0\end{array}$ \\
\hline
\end{tabular}

Not determined.

TABLE C.25. CUMULATIVE MORTALITY OF LEPOMIS MACROCHIRUS EXPOSED TO WP-F SMOKE-DOSED RIVER WATER, BDRN WP-16

\begin{tabular}{|c|c|c|c|c|c|c|c|}
\hline \multirow{2}{*}{$\begin{array}{l}\text { Treatment } \\
(\% \text { stock })\end{array}$} & \multirow{2}{*}{$\frac{\operatorname{Injtial}^{a}}{\mathrm{pH}}$} & \multirow{2}{*}{$\begin{array}{c}\text { Total } \\
(\mathrm{mg} / \mathrm{L})\end{array}$} & \multicolumn{4}{|c|}{ Mortality $\left(\begin{array}{l}0 \\
0\end{array}\right)$} & \multirow{2}{*}{$\begin{array}{c}96-\mathrm{hr} \mathrm{NH}_{3} \\
(\mathrm{\mu g} / \mathrm{L}) \\
\end{array}$} \\
\hline & & & $24 \mathrm{hr}$ & $48 \mathrm{hr}$ & $72 \mathrm{hr}$ & $96 \mathrm{hr}$ & \\
\hline $\begin{array}{c}8.0 \\
7.5 \\
7.0 \\
6.5 \\
6.0 \\
\text { Control }\end{array}$ & $\begin{array}{l}3.66,3.77 \\
3.82,3.92 \\
4.18,4.66 \\
4.79,4.68 \\
5.31,5.38 \\
7.91,7.93\end{array}$ & $\begin{array}{l}45.9,47.3 \\
44.5,45.0 \\
39.5,39.9 \\
38.0,39.0 \\
34.9,35.9 \\
<0.1\end{array}$ & $\begin{array}{r}95 \\
30 \\
0 \\
0 \\
0 \\
0\end{array}$ & $\begin{array}{r}95 \\
45 \\
0 \\
0 \\
0 \\
0\end{array}$ & $\begin{array}{r}100 \\
45 \\
0 \\
0 \\
0 \\
0\end{array}$ & $\begin{array}{r}100 \\
50 \\
0 \\
0 \\
0 \\
0\end{array}$ & $\begin{array}{l}<0.10 \\
<0.10 \\
<0.10 \\
<0.10 \\
<0.10 \\
3.96\end{array}$ \\
\hline
\end{tabular}




\section{APPENDIX 0}

\section{PHFSE II GLP REOUIREMENTS}

Phase II of this study was performed under Good Laboratory Practicess as defined by 40 CFR 792.

This appendix contains the Quality Assurance Unit's staterent for Phase II studies, a 1 ist of personnel assigried to Phase II studies, the study dates for Phase II GLP toxicity tests, and the number of organisms used in Phase II GLP tests.

A1T raw data and the final report are stored in the LSL-II Building, Rooms 1433 at Battelle, Pacific Northwest Laboratories. Duration of data storage will be in compliance with 4D CFR 792.195 or until the U.S. Army requests transfer of the data, whichever occurs first.
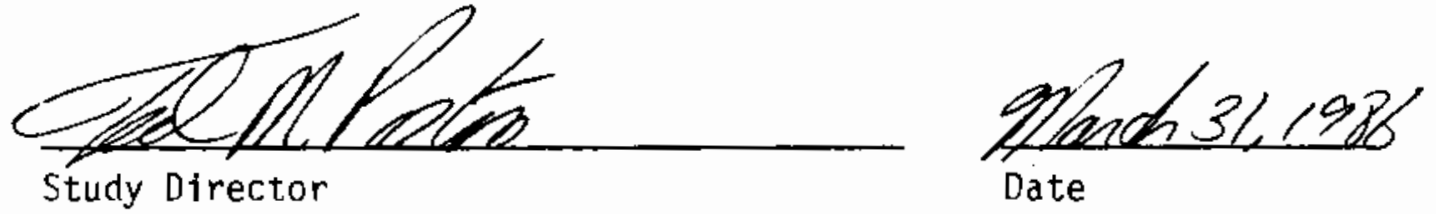

STUDY PERSONNEL

Study Director

Fog 0 il Chemistry

Phosphorus Chemistry

Aerosol Generation

Statistics

Test Organism Culture

Toxicity Testing
T. M. Poston

R. M. Bean

B. L. Thomas

K. M. McFadden

M. L. Clark

B. W. Killiand

L. A. Prohammer

C. S. Abernethy

T. M. Poston

E. W. Lusty

M. T. Mclane

T. P. Lellieux

DEVIATIONS IN: TEST TEMPERATURE

Exposure temperatures deviated by more than $1^{\text {" }} \mathrm{C}$ in the following six tests. Exposure temperatures in the remaining tests did not exceed the range specified in Section 2.

1. Neutralization test with 0 . magna and RP-BR (Thase I). Initial temperatures in this test were 20.3 to $22.0^{\circ} \mathrm{C}$. Temperatures equilibrated at 19.8 to $21.2^{\circ} \mathrm{C}$ at $24 \mathrm{hr}$ and 18.5 to $20.2^{\circ}$ over the: remaining $96 \mathrm{hr}$ of the test. The desired test temperature was $20.0 \pm$ $1.0^{\circ} \mathrm{C}$. 
2. Acute test with $\mathrm{H}$. azteca and RP-BR. Temperatures at $24 \mathrm{hr}$ ranged from 18.4 to $19.1^{\circ} \mathrm{C}$ and at $48 \mathrm{hr}$, ranged froni 17.9 to $18.2^{\circ} \mathrm{C}$. The desired test temperature was $17.0 \pm 1.0^{\circ} \mathrm{C}$.

3. Acute test with $\mathrm{P}$. dissimulus and RP-BR. Temperatures in two heakers at $48 \mathrm{hr}$ were 21.2 . and $21.4^{\circ} \mathrm{C}$. All other monitored temperatures ranged from 20.4 to $21.0^{\circ} \mathrm{C}$. The desired test temperature was $20.0^{\circ} \pm 1.00 \mathrm{C}$.

4. Acute test with bluegill sunfish and RP-BR. Tenperatures at the start of the test and at $24 \mathrm{hr}$ ranged from 18.2 to $20.0^{\circ}$ (control aquaria only), all other aquaria were $19.0^{\circ} \mathrm{C}$ or less. Exposure temperatures fell within the desired range of $17.0 \pm 1.0^{\circ} \mathrm{C}$ for the reniainder of the test.

5. Acute test with rainbow trout and RP-BR. There was ore instance where the exposure temperature fell outside of the range of the desired temperature $\left(12.0 \pm 1.0^{\circ} \mathrm{C}\right)$. At the start of the test, one aquarium registered $10.3^{\circ} \mathrm{C}$.

6. Acute test with rainbow trout and WP-F. Fxposure temperatures rariged from 10.5 to $12.0^{\circ} \mathrm{C}$ at the start of the test and 10.5 to $11.0^{\circ} \mathrm{C}$ at 72 and $96 \mathrm{hr}$. The desired test. temperature wes $12.0 \pm 1.0^{\circ} \mathrm{C}$. Temperatures at $48 \mathrm{hr}$ ranged from 11.0 to $11.4^{\circ} \mathrm{C}$.

PHASE II STUDY DATES

\begin{tabular}{ccc} 
Date & Date & Number of \\
Iritiated & Completed & Organisms \\
\hline
\end{tabular}

Red Phosphorus-Butyl Rubber

S. capricornutum - toxicity

5. capricornutum - stimulation

$09-13-84$

$12-10-84$

D. magna

ก8-28-84

P. dissimilus

$\bar{H}$. azteca

$11-14-84$

$11-14-84$

Fiexagenjáa

$12-05-84$

S. gairdneri

$\bar{p}$. promelas

I. $\frac{\text { punctatus (Test. } 1 \text { ) }}{\text { punctatus }}$

$01-21-85$

$11-06-84$

I. punctatus (Test 2)

ㄷ. macrochirus

$11-06-84$

$12-10-84$

$11-14-84$

$09-17-84$

$M A^{\mathrm{a}}$

$12-14-84$

$08-30-84$

120

$11-16-84 \quad 120$

$11-16-84 \quad 120$

$12-07-84 \quad 120$

$01-25-85 \quad 120$

$11-10-84 \quad 120$

$11-10-84 \quad 120$

$12-14-84 \quad 100$

$11-18-84$

12.0

White Phosphorus-Felt

S. capricornutum - toxicit.j 09-21-84

5. Capricornutum - stimulation 11-30-84

$09-25-84$

$12-04-84$

$01-31-85$

$02-02-85$

NA

NAA

D. magna

120 
PHASE II STUDY DATES (contirued)

P. dissimilus

H. aztecá

Hexagenia

S. gairdneri

$\bar{p}$. promelas

I. punctatus

ㄴ. macrochirus

\begin{tabular}{ccc}
$\begin{array}{c}\text { Dace } \\
\text { Initiated }\end{array}$ & $\begin{array}{c}\text { Date } \\
\text { Completed }\end{array}$ & $\begin{array}{c}\text { Omber or } \\
\text { Organisms }\end{array}$ \\
\hline
\end{tabular}

SGF No. 2 Fog Oil

Batch 1

s. capricornutum - toxicity

$08-21-85$

$08-25-85$

12-01-84

120

$11-29-84$

$12-01-84$

120

$12-17-84$

$12-19-84$

120

$12-17-84$

$12-21-84$

120

$11-29-84$

$12-03-84$

120

$10-30-84$

$11-03-84$

120

$01-28-84$

$02-01-85$

$12 \mathrm{C}$

Eexagenia

F. prometas

$11-26-84$

$11-28-84$

$10-19-84$

NA

$10-15-84$

60

80

Batch 2

S. capricornutum - toxicity

$08-16-84$

$c 8-20-85$

$11-19-84$

$11-21-84$

p. prome las

$10-24-85$

$10-28-85$

lif:

60

40

Batch 3

S. capricorrutum - toxicity

$09-17-84$

$09-21-84$

NA

J. magna

$02-06-85$

$02-08-85$

160

F. dissimilus

H. azteca

Fexagenia

P. prometas

$02-06-85$

$02-08-85$

120

$01-26-85$

48

$11-19-84$

$11-21-84$

$10-28-85$

60

$10-24-34$

40

Vaporized Batch 3

S. capricornutum

D. magna

D. dissimulus

$\bar{H}$. azteca

Texagenia

p. promelas

12-18-84

$01-31-85$

$12-22-84$

NA

$01-31-85$

$02-02-85$

160

$01-15-85$

$02-02-85$

(1) $-17-85$

$12 \mathrm{C}$

$01-15-85$

$01-17-85$

$12 \mathrm{C}$

$01-02-85$

01-06-85

$6 \mathrm{C}$

60

$\overline{a_{\text {Not }} \text { applicable }}$ 
. 
ACUTE TOXICITY OF SMOKE SCREEN MATERIALS TO AOUATIC ORGANISMS - PHASE II

Quality Assurance Statement

Listed below are phases and/or procedures inciaded in the Phase II Tosicity Tests which were reviewed by guality Assurance, dates reviews were performed and dates findings reported to management. (Findings were reported to the study director or his designee dt the time of the review,

\section{Test Procedures Reviewed}

Review Dates

Date Findings Submitted in Writing to

Test: 5. Capricornutum with Batch 2 Fog Oil

$\begin{array}{ll}\text { Dose Preparation } & 08 / 16 / 84 \\ \text { Dosing } & 08 / 16 / 84\end{array}$

Test: 5. capricotnutum with Batch 3 Fog OiI

Dose Preparation $09 / 17 / 84 \quad 09 / 17184$

Dosing $09 / 17 / 84 \quad 09 / 17 / 84$

Test: S. Sapricornutym with WP-F

Dose Erepartion $09 / 21 / 84$

Sample Collection $09 / 27 / 84$

Chlorophyli Analysis $10 / 09 / 84$

Study Director 6 Manzqement

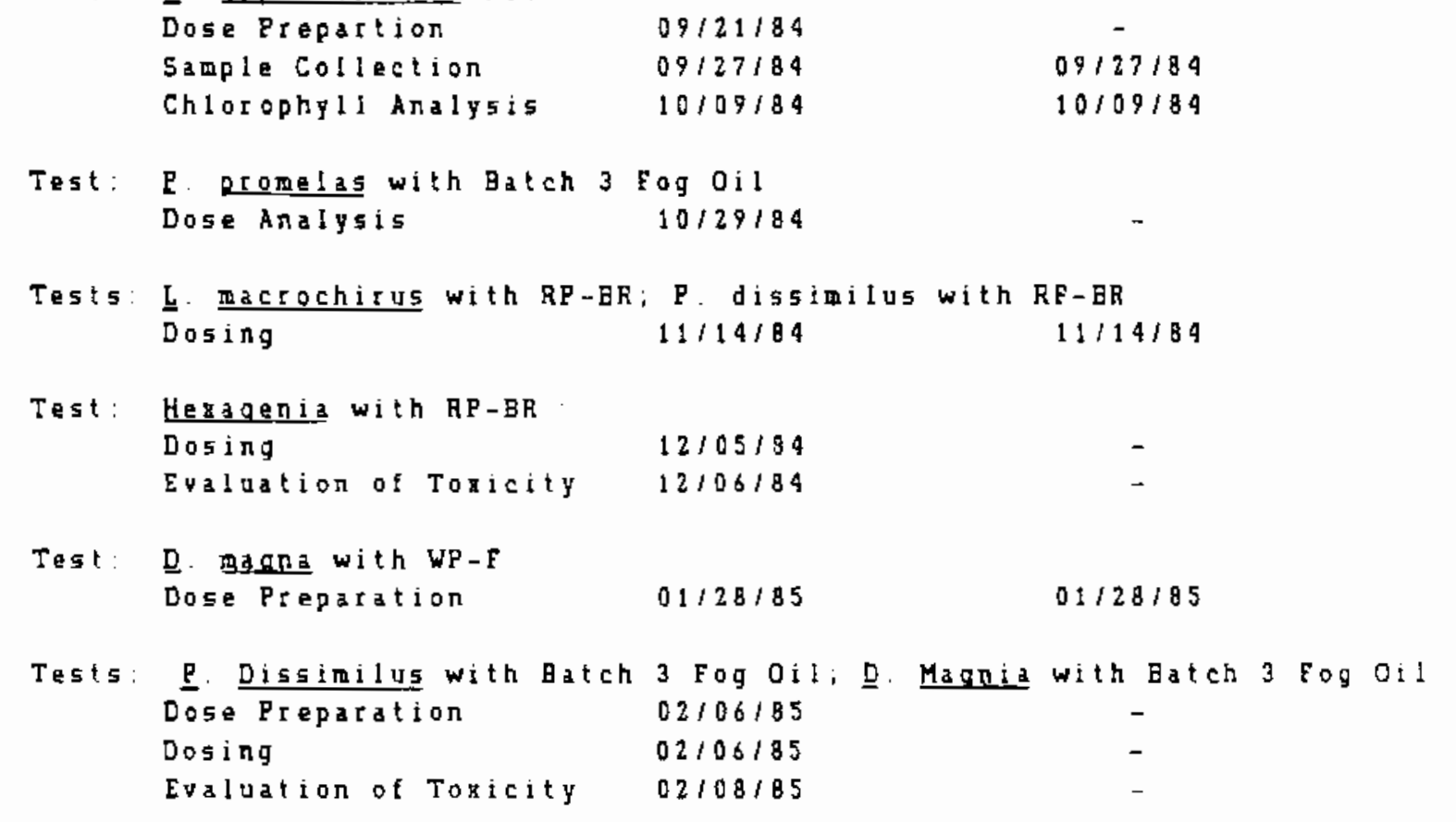


ACUTE TOXICITY OF SMOKE SCREEN MATERIALS TO AOUATIC ORCANISMS - PHASE II

Audit
Data
Data
Data
Data
Data
Final Report

Date Findings subuittad in Writing to

Review Dates

Study Director a Management

$09 / 04 / 84$
$10 / 09 / 84$
$12 / 17-19 / 84$
$01 / 25 / 85$
$01 / 0962 / 13 / 86$
$2 / 14,17818 / 86$

$09 / 12 / 84$

$10 / 09 / 84$

$01 / 07 / 85$

$01 / 25 / 85$

$03 / 22 / 86$

$03 / 22 / 86$

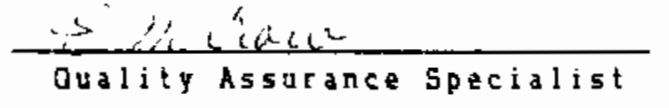

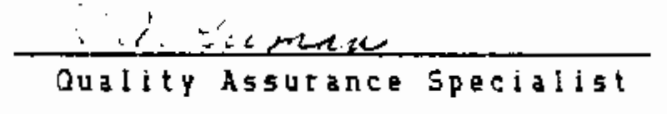

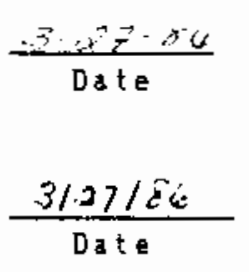




\section{DISTRIBUTION}

No. of

Copies

DFFSITE

28 Comriander

US Amly Medical Bivengineering Research and Development

Laboratory

ATTN: SGRD-UBZ-L

Fort Detrick

Frederick, MD 21701

USAMPDC (SGRD-RNS)

Fort Detrick

Frederick, $M D$ 217DI

12 Adnityistrator

Defense Technical Information

Center

ATTN: DTIC-DDA

Cameron Station

Alexandria, VA 22314

Eean

School of Medicine

Uniformed Services University

of the Health Sciences

4301 Jones Bridge Roid

Bethesda, MD 20014

Commandant

Academy of Health Scierices, US Arniy

ATTN: ARS-CDM

Fort Sam Houston, TX 78234

Commander

IIS Arny Medical Bioengineering Research and Development Laboratory

ATTI: SGRD-UBZ-T/Librarian

Fort Detrick

Frederick, MD 2170 ].
No. of

Copies

ONSTTE

DOE Richlánc Cperationse Office

J. J. Sutey

31 Pacific Nicrthwest Laboratory

D. W. Dragnich

P. C. Havs

T. M. Poston (5)

K. M. McFadden

R. M. Bean

M. L. Clark

B. L. Thomas

B. W. Kiliand

L. A. Prohammer

D. R. Kâlkwarf

C. M. Novich

T. L. Page

R. R. Riley

T. R. Garland

R. A. Gelmari

P. Van Voris

R. E. Wildung

C. E. Elotrkin

J. M. Hales

J. A. Stuttlemyre

Publishing Coordinatiori ( 2 )

Technical Information (5) 


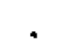

